\title{
WestVirginiaUniversity
}

THE RESEARCH REPOSITORY @ WVU

West Virginia Agricultural and Forestry Experiment

Davis College of Agriculture, Natural Resources

Station Bulletins

And Design

$1-1-1961$

\section{County study data book : measures of social change in West Virginia}

Leonard Marion Sizer

Follow this and additional works at: https://researchrepository.wvu.edu/

wv_agricultural_and_forestry_experiment_station_bulletins

\section{Digital Commons Citation}

Sizer, Leonard Marion, "County study data book : measures of social change in West Virginia" (1961). West Virginia Agricultural and Forestry Experiment Station Bulletins. 464.

https://researchrepository.wvu.edu/wv_agricultural_and_forestry_experiment_station_bulletins/439

This Bulletin is brought to you for free and open access by the Davis College of Agriculture, Natural Resources And Design at The Research Repository @ WVU. It has been accepted for inclusion in West Virginia Agricultural and Forestry Experiment Station Bulletins by an authorized administrator of

The Research Repository@WVU. For more information, please contact ian.harmon@mail.wvu.edu. 

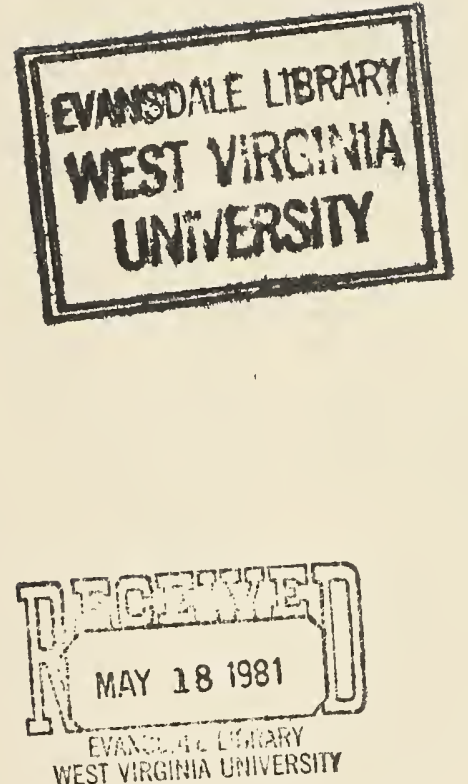


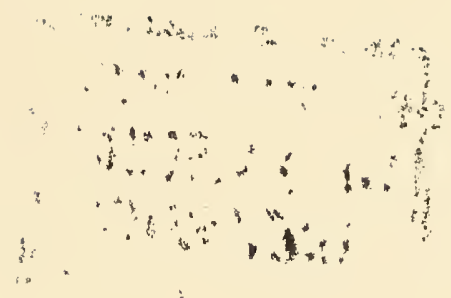

West Virginia University Library

This book is due on the date indicated below.

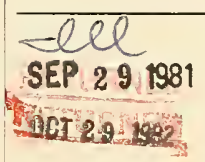

JAN 51386

MAY 312003 
Digitized by the Internet Archive in 2010 with funding from

Lyrasis Members and Sloan Foundation 



\title{
COUNTY STUDY DATA BOOK
}

Measures of Social Change in West Virginia

\author{
Leonard Sizer \\ Associate Rural Sociologist
}

Bulletin No. 464

August, 1961

West Virginia University Agricultural Experiment Station

A. H. VanLandingham, Director

Morgantown, West Virginia 


\section{Contents}

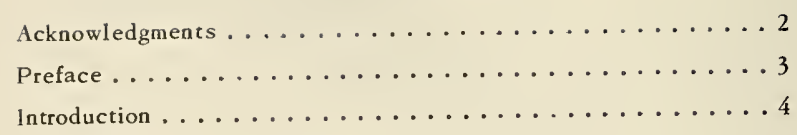

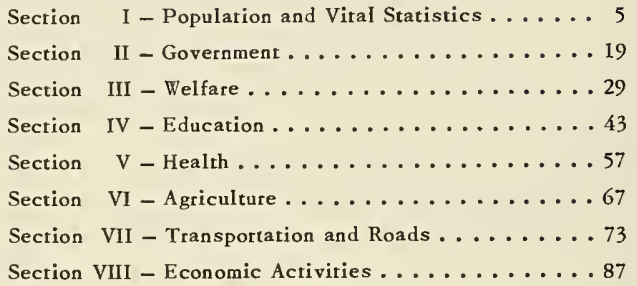

\section{Acknowledgements}

The County Study Data Book is the result of suggestions received from the Northeast Committee on Rural Sociology and the Northeast Technical Committee for Regional Project No. 31, "The Effects of Urban Industrial Expansion on Agriculture in the Northeast." Both committees are composed of staff members of college and university agricultural experiment stations in the Northeast.

The author acknowledges the careful attention given by Mrs. Mary E. Templeton, Research Assistant of the Department of Agricultural Economics and Rural Sociology, in preparation of the numerous tables, and to Mary Chico, Sandra Morrissette, and Donna Mallow, statistical clerks in the Department.

The author wishes to express his appreciation for the help and suggestions of The State Department of Health, Dr. N. H. Dyer, Director, and to the following members of staff and Boards - Paul D. Bibbs, Paul B. Shanks, Harry M. Huff, Dr. A. Brooks Drake, Gilbert Brooks, and Marjorie E. Dumez, R.N.; to Dr. Craig Wilson, Kathleen Kerwood, and Sherril D. McMillen of the State Depart- ment of Education; to John T. Johnson, Commissioner of Agriculture, and Thomas L. Cryer and Alan R. Miller of the Federal-State Crop Reporting Service; to Joseph N. Finerty, Research and Statistical Division, and to Charles J. Parsons, Morgantown office, Department of Employment Security; to Robert R. Cline, Division of Research and Statistics, Department of Public Assistance; to Captain R. E. Schnell, Criminal Investigation Bureau, Department of Public Safety; to Richard Shelton, Assessments and Levy Division, State Tax Commission; to Jones Kelly, Bureau of Vehicles Division, Department of Motor Vehicles; and to Harrey C. Schwender, Monte C. Catlatte, and Robert A. Wilson, State Road Commission.

Others who have contributed to the information in the County Study Data Bookare Earle L. Elmore, Managing Director of the West Virginia Chamber of Commerce; James A. Thompson, Director of the West Virginia University Bureau of Business Research; and Eugene Elkins, Senior Research Analyst, West Virginia Bureau for Government Reseatch. 


\section{Preface}

A MERICAN society is organizing to secure the full benefits of the development of scientific knowledge and its application to the solution of practical problems. The division of labor needed for the understanding and use of specialized knowledge and techniques have increased the complexity of our national, state, and local life. These differentiations in employment have affected all aspects of our lives: manufacturing, transportation, communication, government, education - to mention only a few.

The rapid tempo of changes and their impact upon personal and social adjustment continue, with no definite signs of abating. In a society committed to democratic values, the scope and significance of these changes place the intelligent and concerned citizen in urgent need of information - information which can contribute to his understanding and intelligent participation in the solution of difficult public problems.

There are no blueprints of the design of the future. The continual emergence of new knowledge which needs to be absorbed forbids a solidification of "just what we want." Analyses at national, state, and local levels, however, recognize the potentials of the future, implied in our new knowledge and increased capabilities, and suggest specific goals or specific directions.

The discernment of these goals and the decisions as to the ways in which they may be achieved have become too important and, perhaps, too difficult, to be accomplished without wide-spread knowledge of the needs implied. The gains to be secured for the enrichments of human life are too great to discourage alert and concerned citizens from participating in the enterprise.

The belief in a full recruitment of concerned citizens, who will set themselves to the task of improving human conditions, has been incorporated into national policy of the Rural Areas Development Program. The pattern of Rural Areas Development implies that the professional person does not have the complete answers - he must rely, in part, on the informed and self-disciplined citizen for assistance in making decisions. These most valuable resources, human minds and commitments, must be fully utilized if we are to make wise judgments as to our goals and the steps by which these goals may be reached. 


\section{COUNTY STUDY DATA BOOK Measures of Social Change in West Virginia}

\section{Introduction}

T HE County Study Data Book should be useful to individuals and to local citizen groups in arriving at conclusions relative to schools and other phases of community life in West Virginia. It also may help in evaluating such statements as that recently made by the president of a statewide organization of school board members, who said ". . : : contrary to what many people would have us believe, West Virginia is not regressing."

On-the-spot knowledge of events and conditions are a prerequisite to any meaningful interpretation of these data at the local level. Part of this "on-thespot knowledge" may be common knowledge among local citizens. A pooling of other information may supply additional insights as to what is needed in interpretation and goal selection.

This publication gives specific data on a timeseries and an index basis of social change, and is the result of studying the reports of the public and private state agencies. As the data are used, they should provide guide lines for requesting additional data or procedures for their analyses. The aim in suggesting this additional work at the local level would be to secure a more accurate picture through which more sound judgements could be made. For example, a study of "drop outs" from high schools may be a topic with which local citizens would concern themselves. The data, presented in this book, are only preliminary to an adequate understanding of the topic.

Since the justification for this book is its usefulness to local groups, subsequent issues will have increased usefulness only as local groups share their experiences. Some of the measures of social change reported herein may be dropped, whereas others, if requested, may prove to be more useful to such groups in their planning.

\section{Presentation of Data}

In presenting the data, an attempt was made to secure comparable data for the years 1940, I950, and 1955-1960. It is believed that these will give sufficient depth historically and will indicate the current direction of change.
The year 1950, a census year, was used for the index base of 100 . The use of the index facilitates comparisons through time, and with the State as a whole and with other counties. These comparisons are believed to be those most desired. Comparison with regional or national averages will entail heavy expenditures of research time, but may become necessary.

As financial data were introduced, the dollars were adjusted by the wholesale commodity index $(1947-1949=100)$ with the expectation that the financial data would then be more representative of its purchasing power of goods and services. Much of the fiscal data is based on budget years ending on June 30. The following $\mathrm{table}$ contains the adjustments which were used in calculating data.

\section{Indicies Used in Adjusting Financial Data}

\begin{tabular}{lcc}
\hline Year & $\begin{array}{c}\text { U.S. Wholesale Com- } \\
\text { madity, Index Year } \\
\text { Ending Dec. 31 }\end{array}$ & $\begin{array}{c}\text { Commodity Index } \\
\text { Year Ending } \\
\text { June } 30\end{array}$ \\
\hline 1940 & 51.1 & 50.8 \\
$1947-1949$ & 100.0 & 100.0 \\
1950 & 103.1 & 98.4 \\
1955 & 110.7 & 110.1 \\
1956 & 114.3 & 112.2 \\
1957 & 117.6 & 116.2 \\
1958 & 119.2 & 118.7 \\
1959 & 119.4 & 119.4 \\
1960 & & 119.4 \\
\hline
\end{tabular}

Some "per capita" data are given. The discrepancies between the 1960 final census total for the counties and "Estimates" for the immediately preceding year indicated that tests of methods were desirable. These tests are now being made, with the Bureau of Census cooperating. When completed, revised county totals for the years used will then be available. These totals will make more realistic comparisons possible. 


\section{Section 1 \\ POPULATION AND VITAL STATISTICS}

1A Decenial Census Reports of the Numbers of Inhabitants for the Counties of West Virginia, 1900-1960 ....

1B Index of Population for the Counties of West Virginia, 1900-1960, $1950=100 \ldots$.

2A Population Data for the Counties of West Virginia: Census of Population 1940, 1950 and Estimates for 1955-1958 ...

2B Index of Population Data for the Counties of West Virginia: Census of Population, 1940, 1950 and Estimates for 1955-1958, 1950 $=100 \ldots$.

3A Births (Adjusted for Underregistration) by Place of Residence for the Counties of West Virginia, for Specified Years ....

3B Index of Births (Adjusted for Underregistration) by Place of Residence for the Counties of West Virginia, $1950=100 \ldots \ldots$

$3 \mathrm{C}$ The Crude Birth Rate for the Counties of West Virginia ....

3D Index of Crude Birth Rate for the Counties of West Virginia, 1950 $=100 \ldots$.

4A Deaths by Place of Residence for the Counties of West Virginia for Specified Years ....

4B Index of the Number of Deaths by Place of Residence for the Counties of West Virginia, $1950=100 \ldots$.

4C The Crude Death Rate for the Counties of West Virginia ....

4D Index of Crude Death Rate for the Counties of West Virginia, 1950 $=100 \ldots$. 
Data for 1900 and 1910 were taken Irom Table 1, Supplement for West Virginia, page 674 , of the 13 th Census of the United. States.

Data Ior 1920, 1930, and 1940 were taken from Table 3, Population, First Series, Number of Inhabitants, West Virginia, 16 th Census of the United States.
Data for 1950 were taken from Table 5, Volume II, Characteristics of the Population, Part 48, West Virginia, of the 1950 Census of Population.

Data Ior 1960 were taken from Table 6, Number of Inhabitants, PC (1), 50A, West Virginia, United States Census of Population, 1960.
Section I

POPULATION AND VITAL STATISTICS

W. Vo. Univ.

Agr. Exp. Sto

Bul. No. 464

Page 6

\begin{tabular}{|c|c|c|c|c|c|c|c|}
\hline COUNTY & 1900 & 1910 & 1920 & 1930 & 1940 & 1950 & 1960 \\
\hline Barbour & 24,198 & 15,858 & 18,028 & 18,628 & 19.869 & 19,745 & 15,474 \\
\hline Berkeley & 19,469 & 21,999 & 24,554 & 28,030 & 29,016 & 30,359 & 33,791 \\
\hline Boone & 8,194 & 10,331 & 15,319 & 24,586 & 28,556 & 33,173 & 28,764 \\
\hline Braxton & $18,90_{4}$ & 23,023 & 23,973 & 22,579 & 21,658 & 18,062 & 15,152 \\
\hline Brooke & 7.219 & 11,098 & 16.527 & 24,663 & 25,513 & 26,904 & 28,940 \\
\hline Cabel1 & 29,252 & 46,685 & 65,746 & 90,786 & 97,459 & 108,035 & 108,202 \\
\hline Calhoun & 10.266 & 11,258 & 10,268 & 10,866 & $12,2.55$ & 10,259 & 7,948 \\
\hline Clay & 8,248 & 10,233 & 11,486 & 13,125 & 15,206 & 14,961 & 11,942 \\
\hline Doddridge & 13,689 & 12,672 & 11,976 & 10,488 & 10,923 & 9,026 & 6,970 \\
\hline Fayette & 31.987 & 51,903 & 60,377 & 72,050 & 80,628 & 82,443 & 61,731 \\
\hline Gilmer & 11.762 & 11,379 & 10.668 & 10,641 & 12,046 & 9.746 & 8,050 \\
\hline Grant & 7.275 & 7.838 & 8.993 & 8,441 & 8,805 & 8.756 & 8,304 \\
\hline Greenbrier & 20,683 & 24.833 & 26,242 & 35,878 & 38,520 & 39,295 & 34,446 \\
\hline Hampshire & 11,806 & 11,694 & 11,713 & 11,836 & 12,974 & 12,577 & 11,705 \\
\hline Hancock & 6.693 & 10.465 & 19.975 & 28.511 & 31.572 & 34,388 & 39,615 \\
\hline Hardy & 8,412 & 9.163 & 9,602 & 9,816 & 10,813 & 10,032 & 9,308 \\
\hline Hartison & 27,690 & 48,381 & 74.793 & 78,567 & 82,911 & 85,296 & 77,856 \\
\hline Jackson & 22.987 & 20,956 & 18,658 & 16,124 & 16,598 & 15,299 & 18,541 \\
\hline Jefferson & 15.935 & 15,889 & 15,729 & 15,780 & 16,762 & 17,184 & 18,665 \\
\hline Kanawha & 54,696 & 81,457 & 119,650 & 157,667 & 195,619 & 239,629 & 252,925 \\
\hline Lewis & 16.980 & 18.281 & 20,455 & 21,794 & 22,271 & 21,074 & 19,711 \\
\hline Lincoln & 15,434 & 20,491 & 19,378 & 19,156 & 22,886 & 22,466 & 20,267 \\
\hline Lngan & 6,955 & 14,476 & 41,006 & 58,534 & 67,768 & 77,391 & 61,570 \\
\hline McDowell & 18,747 & 47.856 & 68,571 & 90,479 & 94,354 & 98,887 & 71,359 \\
\hline Marion & 32,430 & 42,794 & 54,571 & 66,655 & 68,683 & 71,521 & 63,717 \\
\hline Marshall & 26,444 & 32.388 & 33.681 & 39,831 & 40,189 & 36,893 & 38,041 \\
\hline Mason & 24,142 & 23,019 & 21,459 & 20,788 & 22,270 & 23,537 & 24,459 \\
\hline Mercer & 23,023 & 38,371 & 49,558 & 61,323 & 68,289 & 75,013 & 68,206 \\
\hline Mineral & 12,883 & 16.674 & 19.849 & 20,084 & 22,215 & 27,333 & 22,354 \\
\hline Miogo & 11.359 & 19,431 & 26,364 & 38,319 & 40,802 & 47,409 & 39,742 \\
\hline Mnanngal ia & 19,019 & 24,334 & 33,618 & 50,083 & 51,252 & 60,797 & 55,617 \\
\hline Monroe & 13.130 & 13,055 & 13,141 & 11,949 & 13,577 & 13,123 & 11,584 \\
\hline Motgan & 7.294 & 7,848 & 8,357 & $8,4,06$ & 8,743 & 8,276 & 8,376 \\
\hline Nicholas & $11 . \angle 03$ & 17,699 & 20,717 & 20,686 & 24,070 & 27,696 & 25,414 \\
\hline Obio & 48,024 & 57.572 & 62,892 & 72,077 & 73,115 & 71,672 & 68,437 \\
\hline Pendletoo & 9,167 & 9,349 & 9,652 & 9,660 & 10,884 & 9,313 & 8,093 \\
\hline Pleasanss & $9,31,5$ & 8,074 & 7,379 & 6.545 & 6,692 & 6,369 & 7,124 \\
\hline Pocahootas & 8.572 & 14,740 & 15,002 & 14,555 & 13,906 & 12,480 & 10,136 \\
\hline Preston & 22,727 & 26,341 & 27,996 & 29,043 & 30,416 & 31,399 & 27,233 \\
\hline Pntnam & 17,330 & 18,587 & 17.531 & 16.737 & 19,511 & 21,021 & 23,561 \\
\hline Raleigh & 12,136 & 25,633 & 12,182 & 68,072 & 86,687 & 96,273 & 77.826 \\
\hline Randolph & 17,670 & 26,028 & 26,804 & 25.049 & 30,259 & 30,558 & 26,349 \\
\hline Ritchie & 18,901 & 17.875 & 16.506 & 15,594 & 15,389 & 12,535 & 10,877 \\
\hline Roane & 19,852 & 21.513 & 20.129 & 19,478 & 20,787 & 18,408 & 15,720 \\
\hline Snmmers & 16,265 & $18,1,20$ & 19,092 & 20,168 & 20,409 & 19,183 & 15,640 \\
\hline Taylor & 14,978 & 16.554 & 18,712 & 19,211 & 19,919 & 18,422 & 15,010 \\
\hline Tucker & 13.133 & 28.675 & 16,791 & 13,374 & 13,173 & 10,600 & 7,750 \\
\hline Tyler & 18,252 & 16,211 & 14.186 & 12,785 & 12,559 & 10,535 & 10,026 \\
\hline Upshur & 11,696 & 16,629 & 17,851 & 17,944 & 18,360 & 19,242 & 18,292 \\
\hline Wayne & 23,619 & 21.081 & 26,012 & 31,206 & 35,566 & 38,696 & 38,977 \\
\hline Websrer & 8,862 & 9,680 & 11.562 & 14,216 & 18,080 & 17,888 & 13,719 \\
\hline Detzel & 22,880 & 23.855 & 23,049 & 22,334 & 22,342 & 20,154 & 19,347 \\
\hline Wirt & 20,284 & 9,047 & 7.536 & 6,358 & 6,475 & 5,119 & 4,391 \\
\hline Wood & 34,152 & 38,001 & 42,306 & 56,521 & 62,399 & 66,540 & 78,331 \\
\hline Wyoming & 8,380 & 10,392 & 15.180 & 20,926 & 29.774 & 37,540 & 34,836 \\
\hline TOTAL & 958,800 & 221,119 & 1.63 .701 & $1,722.205$ & $1,901,974$ & $2,005,552$ & $-2860,421$ \\
\hline
\end{tabular}


TABLE IB. INDEX OF POPULATION FOR THE COUNTIES OF WEST VIRGINIA, $1900-1960,1950=100$

This index has been prepared from the data in the preceding table, Table 1A, Section I.

\begin{tabular}{|c|c|c|c|c|c|c|c|}
\hline COUNTY & 1900 & 1910 & 1920 & 1930 & $19<0$ & 1950 & 1960 \\
\hline Barbour & 71.9 & 80.3 & 91.3 & 94.3 & 100.6 & 100.0 & 78.4 \\
\hline Berkeley & 64.1 & 72,5 & 80.9 & 92,3 & 95.6 & 100.0 & 111.3 \\
\hline Boone & 24.7 & 31.1 & 46.2 & 74.1 & 86.1 & 100.0 & 86.7 \\
\hline Braxton & 104.5 & 127.3 & 132.6 & 124.9 & 119.8 & 100.0 & 83.8 \\
\hline Brooke & 26.8 & 41.2 & 61.4 & 91.7 & 94.8 & 100.0 & 107.6 \\
\hline Cabell & 27.1 & 43.2 & 60.9 & 84.0 & 90.2 & 100.0 & 100.2 \\
\hline Calhoun & 100.1 & 109.7 & 100.1 & 105.9 & 121.4 & 100.0 & 77.5 \\
\hline Clay & 55.1 & 68.4 & 76.8 & 87.7 & 101.6 & 100.0 & 79.8 \\
\hline Doddridge & 151.7 & 140.4 & 132.7 & 116.2 & 121.0 & 100.0 & 77.2 \\
\hline Fayette & 38.8 & 63.0 & 73.2 & 87.4 & 97.8 & 100.0 & 74.9 \\
\hline Gilmer & 120.7 & 116.8 & 109.5 & 109.2 & 123.6 & 100.0 & 82.6 \\
\hline Grant & 83.1 & 89.5 & 102.7 & 96.4 & 100.6 & 100.0 & 94.8 \\
\hline Greeabrier & 52.6 & 63.2 & 66.8 & 91.3 & 98.0 & 100.0 & 87.7 \\
\hline Hampshire & 93.9 & 93.0 & 93.1 & 94.1 & 103.2 & 100.0 & 93.1 \\
\hline Hancock & 19.5 & 30.4 & 58.1 & 82.9 & 91.8 & 100.0 & 115.2 \\
\hline Hardy & 84.2 & 91.3 & 95.7 & 97.8 & 108.8 & 100.0 & 92.8 \\
\hline Hartison & 32.5 & 56.7 & 87.7 & 92.1 & 97.2 & 100.0 & 91.3 \\
\hline Jacksoo & 150.3 & 137.0 & 122.0 & 105.4 & 108.5 & 100.0 & 121.2 \\
\hline Jefferson & 92.7 & 92.5 & 91.5 & 91.8 & 97.5 & 100.0 & 108.6 \\
\hline Kanawba & 22.8 & 34.0 & 49.9 & 65.8 & 81.6 & 100.0 & 105.5 \\
\hline Lewis & 80.6 & 86.7 & 97.1 & 103.4 & 105.7 & 100.0 & 93.5 \\
\hline Liocoln & 68.7 & 91.2 & 86.3 & 85.3 & 101.9 & 100.0 & 90.2 \\
\hline Logao & 9.0 & 18.7 & 53.0 & 75.6 & 87.6 & 100.0 & 79.6 \\
\hline McDowell & 19.0 & 48.4 & 69.3 & 91.5 & 95.4 & 100.0 & 72.2 \\
\hline Marioa & 45.3 & 59.8 & 76.3 & 93.2 & 96.0 & 100.0 & 89.1 \\
\hline Marshall & 71.7 & 87.8 & 91.3 & 108.0 & 108.9 & 100.0 & 103.1 \\
\hline Mason & 102.6 & 97.8 & 91.2 & 88.3 & 94.6 & 100.0 & 103.9 \\
\hline Mercer & 30.7 & 51.2 & 66.1 & 81.7 & 91.0 & 100.0 & 90.9 \\
\hline Mineral & 57.7 & 74.7 & 88.9 & 89.9 & 99.5 & 100.0 & 100.1 \\
\hline Miogo & 24.0 & 11.0 & 55.6 & 80.8 & 86.1 & 100.0 & 83.8 \\
\hline Moooagalia & 31.3 & 40.0 & 55.3 & 82.4 & 84.3 & 100.0 & 91.5 \\
\hline Monroe & 100.1 & 99.5 & 100.1 & 91.1 & 103.5 & 100.0 & 88.3 \\
\hline Morgaa & 88.1 & 94.8 & 101.0 & 101.6 & 105.6 & 100.0 & 101.2 \\
\hline Nicholas & 41.2 & 63.9 & 74.8 & 74.7 & 86.9 & 100.0 & 91.8 \\
\hline Ohio & 67.0 & 80.3 & 87.7 & 100.6 & 102.0 & 100.0 & 95.5 \\
\hline Pendleton & 98.4 & 100.4 & 103.6 & 103.7 & 116.9 & 100.0 & 86.9 \\
\hline Pleasants & 146.7 & 126.8 & 115.9 & 102.8 & 105.1 & 100.0 & 111.9 \\
\hline Pocahootas & 68.7 & 118.1 & 120.2 & 116.6 & 111.4 & 100.0 & 81.2 \\
\hline Preston & 72.4 & 83.9 & 89.2 & 92.5 & 96.9 & 100.0 & 86.7 \\
\hline Putnam & 82.4 & 88.4 & 83.4 & 79.6 & 92.8 & 200.0 & 112.1 \\
\hline Raleigh & 12.9 & 26.6 & 4.1 & 70.7 & 90.0 & 100.0 & 80.8 \\
\hline Randolph & 57.8 & 85.2 & 87.7 & 82.0 & 99.0 & 100,0 & 86.2 \\
\hline Ritchie & 150.8 & 142.6 & 131.7 & 124.4 & 122.8 & 100.0 & 86.8 \\
\hline Roane & 107.8 & 117.0 & 109.3 & 105.8 & 112.9 & 100.0 & 85.4 \\
\hline Surmmers & 84.8 & 96.0 & 99.5 & 106.7 & 106.4 & 100,0 & 81.5 \\
\hline Taylor & 81.3 & 89.9 & 101.7 & 103.8 & 108.1 & 100.0 & 87.5 \\
\hline Tucket & 126.7 & 176.2 & 158.4 & 126.2 & 124.3 & 100,0 & 73.1 \\
\hline Tylez & 173.3 & 153.9 & 134.7 & 121.4 & 119.2 & 100.0 & 95.2 \\
\hline Upshur & 76.4 & 86.4 & 92.8 & 93.3 & 95.4 & 100.0 & 95.1 \\
\hline Wayoe & 61.0 & 62.2 & 67.2 & 80.6 & 91.9 & 100.0 & 100.7 \\
\hline Webster & 49.5 & 54.1 & 64.6 & 79.5 & 101.1 & 100.0 & 76.7 \\
\hline Wetzel & 113.5 & 118.4 & 114.5 & 110.8 & 110.9 & 100.0 & 96.0 \\
\hline$\overline{W_{\text {irt }}}$ & 200.9 & 176.7 & 147.2 & 124.2 & 126.5 & 100.0 & 85.8 \\
\hline Wood & 51.8 & 57.2 & 63.6 & 84.9 & 93.8 & 100.0 & 117.7 \\
\hline Wyoming & 22.3 & 27.7 & 40.4 & 55.7 & 79.3 & 100.0 & 92.8 \\
\hline TOTAL & 47.807 & 60.887 & 72.982 & 86.221 & 94.835 & 100.0 & 92.8 \\
\hline
\end{tabular}

Section I

POPULATION AND VITAL STATISTICS

W. Vo. Univ.

Agr. Exp. Sta.

Bul. No. 464

Page 7 
Data for 1940 and 1950 were taken from Table 5, Volnme II, Characteristics of the Population, Part 48, West Virginia, of the 1950 Census of Population. The estimates of population for 1955-1958 were prepared by the Department of Agricultural Economics and Rural Sociology, College of Agriculture, Forestry, and Home Economics, West Virginia University, following a recommended procedure of the Bureau of Census, United States Department of Commerce. This method is known as "Migration and Natural Increase, Method II."
The 1960 Census of Population's final count indicates that these data should be revised. The Department of Agricultural Economics and Rural Sociology is cooperating with the Bureau of the Census in applying several techniques to migration and vital statistics data which, it is hoped will provide a method for increasing accuracy. These techniques will be tested by the decennial census.
Section I

POPULATION AND VITAL STATISTICS

W. Ya. Univ.

Agr. Exp. Sta.

Bul. No. 464

Page 8

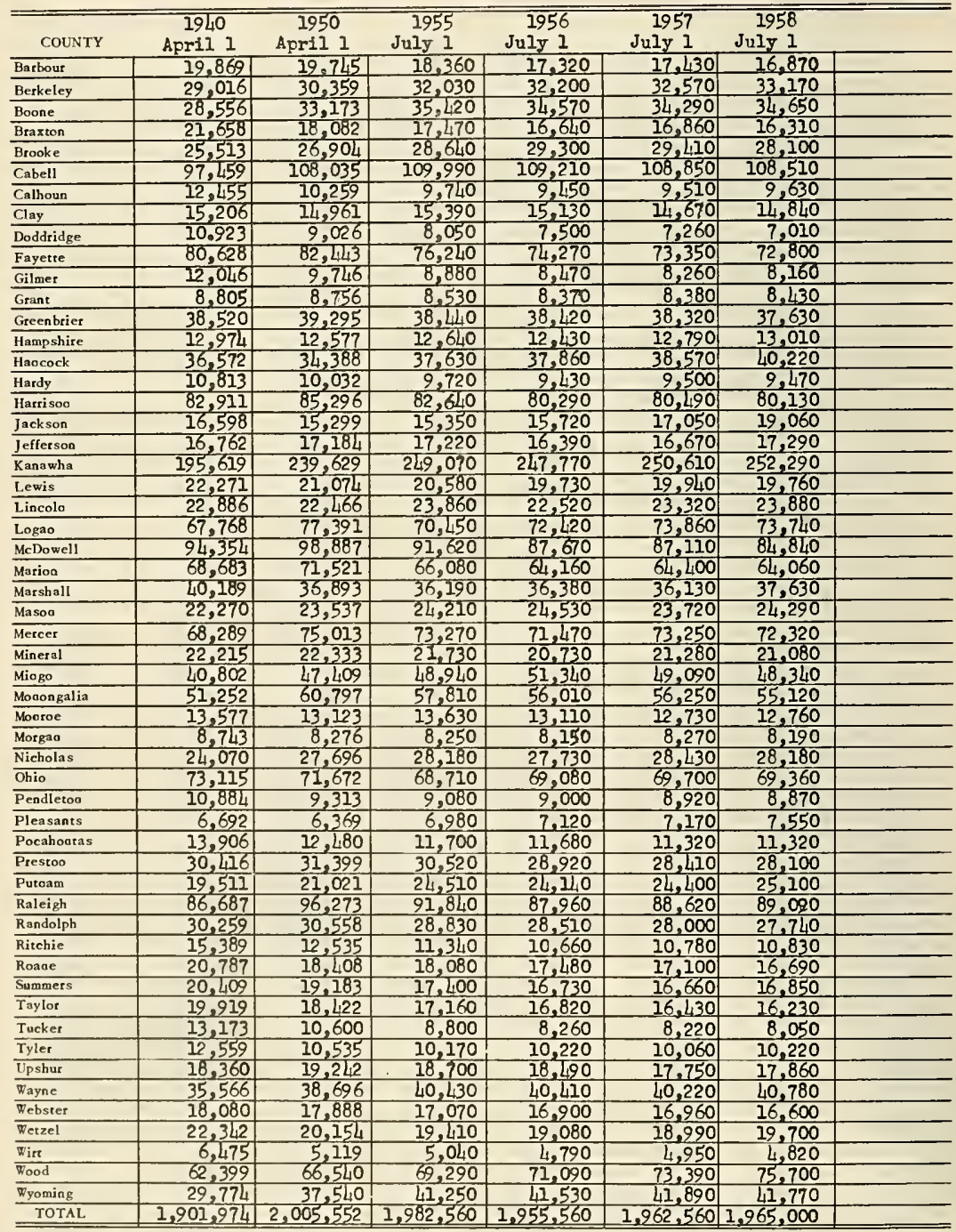


TABLE 2B. INDEX OF POPULATION DATA FOR THE COUNTIES OF WEST VIRGINIA: CENSUS OF POPULATION, 1940, 1950 AND ESTIMATES FOR $1955-1958, \quad 1950=100$

This index was prepared from data presented in the preceding table, Table $2 \mathrm{~A}$, Section 1 . When the data of that table are revised, this index will be revised also.

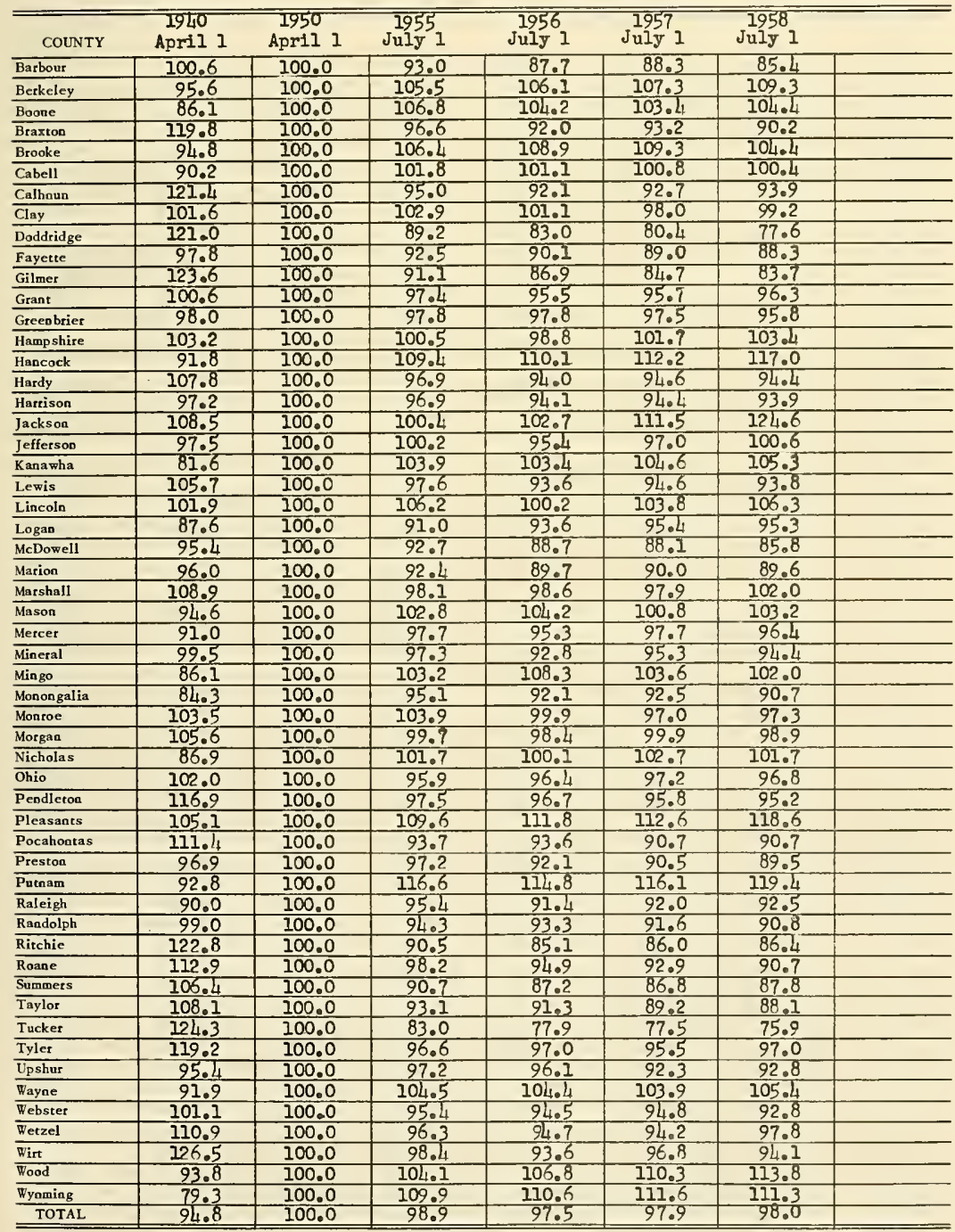

Section I POPULATION AND VITAL STATISTICS

W. Va. Univ.

Agr. Exp. Sta.

Bul. Na. 464

Page 9 


\section{TABLE 3A. BIRTHS (ADJUSTED FOR UNDERREGISTRATION) BY PLACE OF RESIDENCE FOR THE COUNTIES OF WEST VIRGINIA FOR SPECIFIED YEARS}

The number of births is taken for the respective years from Vital Statistics of the United States, published by the National Office of Vital Statistics of the United States Department of Health, Education, and Welfare or from photostatic copies (for more recent years) of reports furnished by the West Virginia Department of Health. The 1940 figures are adjusted for underregistration in accordance with the special data furnished by the National Office of Vital Statistics for use in preparing the net migration data.
The 1950 figures are the data adjusted for underregistration in accordance with Vital Statistics, Special Reports, Volume 39, No. 4, Birth Registration Completeness in the United States and Geographic Area, published by the National Office of Vital Statistics. The 1955 and following birth data are based on the 1950 findings but with adjustments for improvement, chiefly through increased use of hospital for maternity cases.
Section 1

POPULATION ANO VITAL STATISTICS
W. Va. Univ. Agr. Exp. Sta. Bul. Na. 464

Page 10

\begin{tabular}{|c|c|c|c|c|c|c|c|}
\hline COUNTY & 1940 & 1950 & 1955 & 1956 & 1957 & 1958 & 1959 \\
\hline Barbour & 541 & 426 & 358 & 337 & 316 & 347 & 324 \\
\hline Berkeley & 521 & 688 & 707 & 709 & 785 & 759 & 718 \\
\hline Boone & 935 & 1,064 & 916 & 872 & 889 & 808 & 673 \\
\hline Braxron & 569 & 196 & 368 & 365 & 331 & 362 & 371 \\
\hline Brooke & 176 & 528 & 613 & 584 & 660 & 688 & 688 \\
\hline Cabell & 2.218 & 2,641 & 2,513 & 2.656 & 2,554 & 2,562 & 2,356 \\
\hline Calhoun & 379 & 257 & 194 & 162 & 176 & 156 & 159 \\
\hline Clay & 460 & 583 & 1.70 & 1,02 & 391 & 1,15 & 333 \\
\hline Doddridge & 272 & 182 & 139 & 119 & 227 & 151 & 157 \\
\hline Fayette & 2,440 & 2,472 & 1,814 & 1,717 & 1.656 & 1.532 & 1,420 \\
\hline Gilmer & 304 & 196 & 173 & 132 & 146 & 157 & 190 \\
\hline Grant & 280 & 243 & 187 & 204 & 178 & 188 & 205 \\
\hline Greenbrier & 960 & 1,177 & 957 & 882 & 884 & 849 & 807 \\
\hline Hampshire & 295 & 287 & 226 & 257 & 224 & 246 & 227 \\
\hline Hancock & 703 & 847 & 936 & 960 & 1,019 & 955 & 1,039 \\
\hline Hardy & 260 & 234 & 218 & 208 & 201 & 190 & 206 \\
\hline Harrison & 1.759 & 1.953 & 1,777 & 1.755 & 1.707 & 1,779 & 1,615 \\
\hline Jackson & 448 & 330 & 300 & 321 & 405 & 475 & 530 \\
\hline Jefferson & 406 & 405 & 430 & 455 & 465 & 447 & 433 \\
\hline Kanawha & 5,108 & 6,937 & 6,886 & 6,532 & 6.570 & 6,615 & 6,414 \\
\hline Lewis & 399 & 428 & 365 & 373 & 384 & 365 & 365 \\
\hline Lincoln & 761 & 622 & 639 & 606 & 583 & 620 & 528 \\
\hline Logan & 2,249 & 2,669 & 1,863 & 2,206 & 1,970 & 1,934 & 1,706 \\
\hline McDowell & 3,362 & 3,386 & 2,530 & 2,456 & 2,400 & 2,320 & 2,032 \\
\hline Marion & 1,464 & 1,587 & 1,300 & 1,236 & 1,385 & 1,341 & 1,296 \\
\hline Marshall & 747 & 726 & 674 & 712 & 791 & 795 & 806 \\
\hline Mason & 545 & 563 & 615 & 583 & 567 & 651 & 600 \\
\hline Mercer & 1,831 & 1,951 & 1,683 & 1,691 & 1,737 & 1,637 & 1,527 \\
\hline Mineral & 535 & 582 & 469 & 387 & 474 & 452 & 473 \\
\hline Mingo & 1,425 & 1,738 & 1,424 & 1,325 & 1,243 & 1,351 & 1,244 \\
\hline Monsngalia & 1,105 & 2,446 & 1,195 & 1,321 & 1,289 & 1,350 & 1,189 \\
\hline Manroe & 307 & 275 & 255 & 228 & 242 & 228 & 227 \\
\hline Morgan & 201 & 207 & 209 & 217 & 227 & 219 & 212 \\
\hline Nicholas & 594 & 919 & 729 & 702 & 703 & 730 & 643 \\
\hline Ohio & 1,302 & 1,655 & 1,588 & 1,556 & 1,522 & 1,539 & 1,591 \\
\hline Pendleton & 305 & 217 & 211 & 191 & 186 & 177 & 184 \\
\hline Pleasants & 171 & 160 & 152 & 147 & 150 & 170 & 157 \\
\hline Pocahontas & 347 & 274 & 295 & 287 & 265 & 249 & 246 \\
\hline Preston & 793 & 836 & 730 & 682 & 658 & 669 & 674 \\
\hline Putnam & 457 & 508 & 455 & 467 & 497 & 462 & 40 \\
\hline Raleigh & 2,686 & 2,880 & 2,054 & 1,967 & 2,108 & 2,182 & 1,898 \\
\hline Randolph & 753 & 793 & 666 & 647 & 612 & 594 & 648 \\
\hline Ritchie & 323 & 255 & 204 & 222 & 191 & 225 & 251 \\
\hline Roane & 465 & 430 & 344 & 277 & 304 & 294 & 266 \\
\hline Summers & 468 & 265 & 358 & 379 & 332 & 349 & 299 \\
\hline Taylor & 401 & 122 & 321 & 320 & 302 & 293 & 313 \\
\hline Tucker & 307 & 239 & 207 & 184 & 183 & 208 & 169 \\
\hline Tyler & 227 & 220 & 189 & 272 & 185 & 196 & 229 \\
\hline Upshur & 405 & 507 & 417 & 392 & 406 & 375 & 379 \\
\hline Wayne & 955 & 1,026 & 814 & 811 & 804 & 829 & 832 \\
\hline Webster & 5112 & 499 & 347 & 388 & 418 & 407 & 345 \\
\hline Wetzel & 471 & 473 & 410 & 431 & 435 & 422 & 493 \\
\hline Wirt & 147 & 102 & 90 & 97 & 96 & 99 & 91 \\
\hline Wood & 1,198 & 1,696 & 1,741 & 1,922 & 1,973 & 2,021 & 1,967 \\
\hline Woming & 7,086 & 1.233 & 1,037 & 1,157 & 1,089 & 1,032 & 970 \\
\hline TOTAL & 48,668 & 53,919 & 46,792 & 46,268 & 46,395 & 46,466 & 44,145 \\
\hline
\end{tabular}


TABLE 3B. INDEX OF BIRTHS (ADJUSTED FOR UNDERREGISTRATION) BY

PLACE OF RESIDENCE FOR THE COUNTIES OF WEST VIRGINIA, $1950=100$

\begin{tabular}{|c|c|c|c|c|c|c|c|}
\hline COUNTY & 1940 & 1950 & 1955 & 1956 & 1957 & 1958 & 1959 \\
\hline Barbour & 127.0 & 100.0 & 84.0 & 79.1 & 74.2 & 87.5 & 76.1 \\
\hline Berkeley & 75.7 & 100.0 & 102.8 & 103.1 & 114.1 & 110.3 & 10h.4 \\
\hline Boone & 87.9 & 100.0 & 86.1 & 82.0 & 83.6 & 75.9 & 63.3 \\
\hline Braxton & 111.67 & 100.0 & 74.2 & 73.6 & 66.7 & 73.0 & 74.8 \\
\hline Brooke & 90.2 & 100.0 & 121.8 & 310.6 & 125.0 & 130.3 & 130.3 \\
\hline Cabell & 84.0 & 100.0 & 95.2 & 100,6 & 96.7 & 97.0 & 89.2 \\
\hline Calhoun & 316.5 & 100.0 & 75.5 & 63.0 & 68.5 & 60.7 & 61.9 \\
\hline Clay & 78.9 & 100.0 & 80.6 & 69.0 & 67.1 & 71.2 & 57.1 \\
\hline Doddridge & 119.4 & 100.0 & 76.4 & 65.4 & 69.8 & 83.0 & 86,3 \\
\hline Fayette & 98.7 & 100.0 & 73.4 & 69.5 & 67.0 & 62.0 & 57.0 \\
\hline Gilmer & 155.1 & 100.0 & 88.3 & 67.3 & 74.5 & 80.1 & 96.9 \\
\hline Grant & 115.2 & 100.0 & 77.0 & 84.0 & 73.3 & 77.4 & 84.4 \\
\hline Greenbrier & 81.6 & 100.0 & 81.3 & 74.9 & 75.1 & 72.1 & 68.6 \\
\hline Hampshire & 102.8 & 100.0 & 78.7 & 89.5 & 78.0 & 85.7 & 79.1 \\
\hline Hancock & 83.6 & 100.0 & 111.3 & 114.1 & 121.2 & 113.6 & 123.5 \\
\hline Hardy & 111.1 & 100.0 & 93.2 & 88.9 & 85.9 & 81.2 & 88.0 \\
\hline Harrison & 90.1 & 100.0 & 91.0 & 89.9 & 87.4 & 91.1 & 82.7 \\
\hline Jackson & 135.8 & 100.0 & 90.9 & 97.3 & 122.7 & 143.9 & 160.6 \\
\hline Jefferson & 100.2 & 100.0 & 106.2 & 112.3 & 114.8 & 110.4 & 106.9 \\
\hline Kana wha & 73.6 & 100.0 & 99.3 & 94.2 & 94.7 & 95.4 & 92.5 \\
\hline Lewis & 95.5 & 100.0 & 87.3 & 89.2 & 91.9 & 87.3 & 87.3 \\
\hline Lincaln & 122.3 & 100.0 & 102.7 & 97.4 & 93.7 & 99.7 & 84.9 \\
\hline Logan & 84.3 & 100.0 & 69.8 & 78.9 & 73.8 & 72.5 & 63.9 \\
\hline McDowell & 99.3 & 100.0 & 74.7 & 72.5 & 70.9 & 68.5 & 60.0 \\
\hline Marion & 92.2 & 100.0 & 81.9 & 77.9 & 87.3 & 84.5 & 81.7 \\
\hline Marshall & 102.9 & 100.0 & 92.8 & 98.1 & 109.0 & 109.5 & 111.0 \\
\hline Mason & 96.8 & 100.0 & 109.2 & 103.6 & 100.7 & 115.6 & 106.6 \\
\hline Mercer & 93.8 & 100.0 & 86.3 & 86.7 & 89.0 & 83.9 & 78.3 \\
\hline Mineral & 91.9 & 100.0 & $80 . \overline{6}$ & 66.5 & 81.4 & 77.7 & 81.3 \\
\hline Mingo & 82.0 & 100.0 & 81.9 & 76.2 & 71.5 & 77.7 & 71.6 \\
\hline Monongalia & 764 & 100.0 & 82.6 & 91.4 & 89.1 & 93.4 & 82.2 \\
\hline Monrne & 111.6 & 100.0 & 92.7 & 82.9 & 88.0 & 82.9 & 82.5 \\
\hline Morgan & 97.1 & 100.0 & 101.0 & 104.8 & 109.7 & 105.8 & 102.4 \\
\hline Nicholas & 6.6 & 100,0 & 79.3 & 76.4 & 76.5 & 79.4 & 70.0 \\
\hline Ohio & 78.7 & 100.0 & 96.0 & 94.0 & 92.0 & 93.0 & 96.1 \\
\hline Pendleton & 140.6 & 100.0 & 97.2 & 88.0 & 85.7 & 81.6 & 84.8 \\
\hline Pleasants & 106.9 & 100.0 & 95.0 & 91.9 & 93.8 & 106.2 & 98.1 \\
\hline Pocahontas & 126.6 & 100.0 & 107.7 & 104.7 & 96.7 & 90.9 & 89.8 \\
\hline Preston & 94.9 & 100.0 & 87.3 & 81.6 & 78.7 & 80.0 & 80.6 \\
\hline Putnam & 90.0 & 100.0 & 89.6 & 91.9 & 97.8 & 90.9 & 86.6 \\
\hline Raleigh & 93.3 & 100.0 & 71.3 & 68.3 & 73.2 & 75.8 & 65.9 \\
\hline Raodolph & 95.0 & 100.0 & 84.0 & 81.6 & 77.2 & 74.9 & 81.7 \\
\hline Rirchie & 126.7 & 100.0 & 80.0 & 87.1 & 74.9 & 88.2 & 98.4 \\
\hline Roane & 108.1 & 100.0 & 80.0 & 64.4 & 70.7 & 68.4 & 61.9 \\
\hline Summets & 100.6 & 100.0 & 77.0 & 81.5 & 71.4 & 75.1 & 64.3 \\
\hline Taylor & 95.0 & 100.0 & 76.1 & 75.8 & 71.6 & 69.4 & 74.2 \\
\hline Tucker & 128.5 & 100.0 & 86.6 & 77.0 & 76.6 & 87.0 & 70.7 \\
\hline Tyler & 103.2 & 100.0 & 85.9 & 78.2 & 84.1 & 89.1 & 104.1 \\
\hline Upshur & 79.9 & 100.0 & 82.2 & 77.3 & 80.1 & 74.0 & 74.8 \\
\hline Wayne & 93.1 & 100.0 & 79.3 & 79.0 & 78.4 & 80.8 & 81.1 \\
\hline Webster & 108.6 & 100.0 & 69.5 & 77.8 & 83.8 & 81.5 & 69.1 \\
\hline Wetzel & 99.6 & 100.0 & 86.7 & 91.9 & 92.0 & 89.2 & 104.2 \\
\hline Wirt & 244.1 & 100.0 & 88.2 & 95.1 & 94.1 & 97.1 & 89.2 \\
\hline Wood & 70.6 & 100.0 & 102.7 & 113.3 & 116.3 & 119.2 & 116.0 \\
\hline Wyoming & 88.1 & 100.0 & 84.1 & 93.8 & 88.3 & 83.7 & 78.7 \\
\hline TOTAL & 90.3 & 100.0 & 86.8 & 85.8 & 86.0 & 86.2 & 81.9 \\
\hline
\end{tabular}

Section 1

POPULATION AND VITAL STATISTICS
W. Va. Univ.
Agr. Exp. Sta.

Bul. No. 464

Page 11 
TABLE 3C. THE CRUDE BIRTH RATE FOR THE COUNTIES OF WEST VIRGINIA

Data in this table were computed by dividing the data in Table $3 \mathrm{~A}$, this section, by those in Table $2 \mathrm{~A}$, this section, and multiplying the quotient by 1,000 . This is standard procedure for developing the crude birth rate. The results may be interpreted as the number of births per 1,000 population for the given geographic area.

Section 1

POPULATION AND

VITAL STATISTICS
W. Va. Univ.

Agr. Exp. Sta.

But. No. 464

Page 12

\begin{tabular}{|c|c|c|c|c|c|c|}
\hline COUNTY & 1940 & 1950 & 1955 & 1956 & 1957 & 1958 \\
\hline Barbour & 27.2 & 27.6 & 19.5 & 19.5 & 18.7 & 20.6 \\
\hline Berkeley & 18.0 & 22.7 & 22.1 & 22.0 & 24.1 & 22.9 \\
\hline Boone & 32.7 & 32.1 & 25.9 & 25.2 & 25.9 & 23.3 \\
\hline Braxton & 26.3 & 27.4 & 21.1 & 21.9 & 19.6 & 22.2 \\
\hline Bronke & 18.7 & 19.6 & 22.5 & 19.9 & 22.4 & 24.5 \\
\hline Cabell & 22.8 & 24.4 & 22.8 & 24.3 & 23.5 & 23.6 \\
\hline Calhaun & 30.4 & 25.1 & 19.9 & 17.1 & 18.5 & 16.2 \\
\hline Clay & 30.3 & 39.0 & 30.5 & 26.6 & 26.7 & 28.0 \\
\hline Doddridge & 24.9 & 20.2 & 17.3 & 15.9 & 13.7 & 21.6 \\
\hline Fayette & 30.3 & 30.0 & 23.8 & 23.1 & 22.6 & 21.0 \\
\hline Gilmer & 25.2 & 20.1 & 19.5 & 15.6 & 17.7 & 19.2 \\
\hline Grant & 31.8 & 27.8 & 21.9 & 24.4 & 21.2 & 22.3 \\
\hline Greenbrier & 24.9 & 30.0 & 24.9 & 23.0 & 23.1 & 22.6 \\
\hline Hampshire & 22.7 & 22.8 & 17.9 & 20.7 & 17.5 & 18.9 \\
\hline Hancack & 22.3 & 24.5 & 24.9 & 25.4 & 26.4 & 23.7 \\
\hline Hardy & 24.0 & 23.3 & 22.4 & 22.1 & 21.2 & 20.1 \\
\hline Harrisan & 21.2 & 22.9 & 21.5 & 21.9 & 21.2 & 22.2 \\
\hline Jackson & 27.0 & 21.6 & 19.5 & 20.4 & 23.8 & 24.9 \\
\hline Jefferson & 24.2 & 23.6 & 25.0 & 27.8 & 27.9 & 25.8 \\
\hline Kanawha & 26.1 & 28.9 & 27.6 & 26.4 & 26.2 & 26.2 \\
\hline Lewis & 17.9 & 19.8 & 17.7 & 18.2 & 19.3 & 18.5 \\
\hline Lincola & 33.3 & 27.7 & 26.8 & 26.9 & 25.0 & 26.0 \\
\hline Lagan & 33.2 & 34.5 & 26.4 & 29.1 & 26.7 & 26.2 \\
\hline McDowell & 35.6 & 34.2 & 27.6 & 28.0 & 27.6 & 27.3 \\
\hline Marion & 21.3 & 22.2 & 19.7 & 19.3 & 21.5 & 20.9 \\
\hline Marshall & 18.6 & 19.7 & 18.6 & 19.6 & 21.9 & 21.1 \\
\hline Mason & 24.5 & 23.9 & 25.4 & 23.8 & 23.1 & 26.8 \\
\hline Mercer & 26.8 & 26.0 & 23.0 & 23.7 & 24.3 & 22.6 \\
\hline Mineral & 24.1 & 26.1 & 27.6 & 18.7 & 22.3 & 21.4 \\
\hline Miago & 34.9 & 36.7 & 29.1 & 25.8 & 25.3 & 27.9 \\
\hline Monongalia & 21.6 & 23.8 & 20.7 & 23.6 & 22.9 & 24.5 \\
\hline Monine & 22.6 & 21.0 & 18.7 & 17.4 & 18.5 & 17.9 \\
\hline Morgan & 23.0 & 25.0 & 25.3 & 26.6 & 27.4 & 26.8 \\
\hline Nichalas & 24.7 & 33.2 & 25.9 & 25.3 & 24.7 & 25.9 \\
\hline Ohis & 17.8 & 23.1 & 23.1 & 22.5 & 21.8 & $22 . ?$ \\
\hline Pendleta & 28.0 & 23.3 & 23.2 & 21.2 & 20.9 & 20.0 \\
\hline Pleasants & 25.6 & 25.1 & 21,8 & 20,6 & 20.9 & 22.5 \\
\hline Pocahontas & 25.0 & 22.0 & 25.2 & 24.6 & 23.4 & 22.0 \\
\hline Preston & 26.1 & 26.6 & 23.9 & 23.6 & 23.2 & 23.8 \\
\hline Putaam & 23.4 & 24.2 & 18.6 & 19.3 & 20.4 & 18.4 \\
\hline Raleigh & 31.0 & 29.9 & 22.4 & 22.4 & 23.8 & 24.5 \\
\hline RandoIph & 24.9 & 26.0 & 23.1 & 22.7 & 21.9 & 21.4 \\
\hline Ritchic & 21.0 & 20.3 & 18.0 & 20.8 & 17.7 & 20.8 \\
\hline Roane & 22.4 & 23.4 & 19.0 & 15.8 & 17.8 & 17.6 \\
\hline Summers & 22.9 & 24.2 & 20.6 & 22.6 & 19.9 & 20.7 \\
\hline Taylor & 20.1 & 22.9 & 18.7 & 19.0 & 18.4 & 18.1 \\
\hline Tucke: & 23.3 & 22.5 & 23.5 & 22.3 & 22.3 & 25.9 \\
\hline Tyler & 18.1 & 20.9 & 18.6 & 16.8 & 18.4 & 19.2 \\
\hline Upahur & 22.1 & 26.3 & 22.3 & 21.2 & 22.9 & 21.0 \\
\hline Wayne & 26.9 & 26.5 & 20.1 & 20.1 & 20.0 & 20.3 \\
\hline Webster & 30.0 & 27.9 & 20.3 & 23.0 & 24.0 & 24.5 \\
\hline Wetzel & 21.1 & 23.5 & 21.1 & 22.6 & 22.9 & 21.4 \\
\hline Wirt & 22.7 & 19.9 & 17.9 & 20.3 & 19.4 & 20.5 \\
\hline Wood & 19.2 & 25.5 & 25.1 & 27.0 & 26.9 & $26 . ?$ \\
\hline Wyoming & 36.5 & 32.8 & 25.1 & 27.9 & 26.0 & 24.7 \\
\hline TOTAL & 25.6 & 26.9 & 23.6 & 23.7 & 23.6 & 23.6 \\
\hline
\end{tabular}




\section{TABLE 3D. INDEX OF CRUDE BIRTH RATE FOR THE COUNTIES OF WEST \\ VIRGINIA, $1950=100$}

The changes indicated by this index may be the results of an increase or decrease in the number of births for the number of women of child-bearing age or an increase or decrease in the relative number of women (of child-bearing age) due to migration.

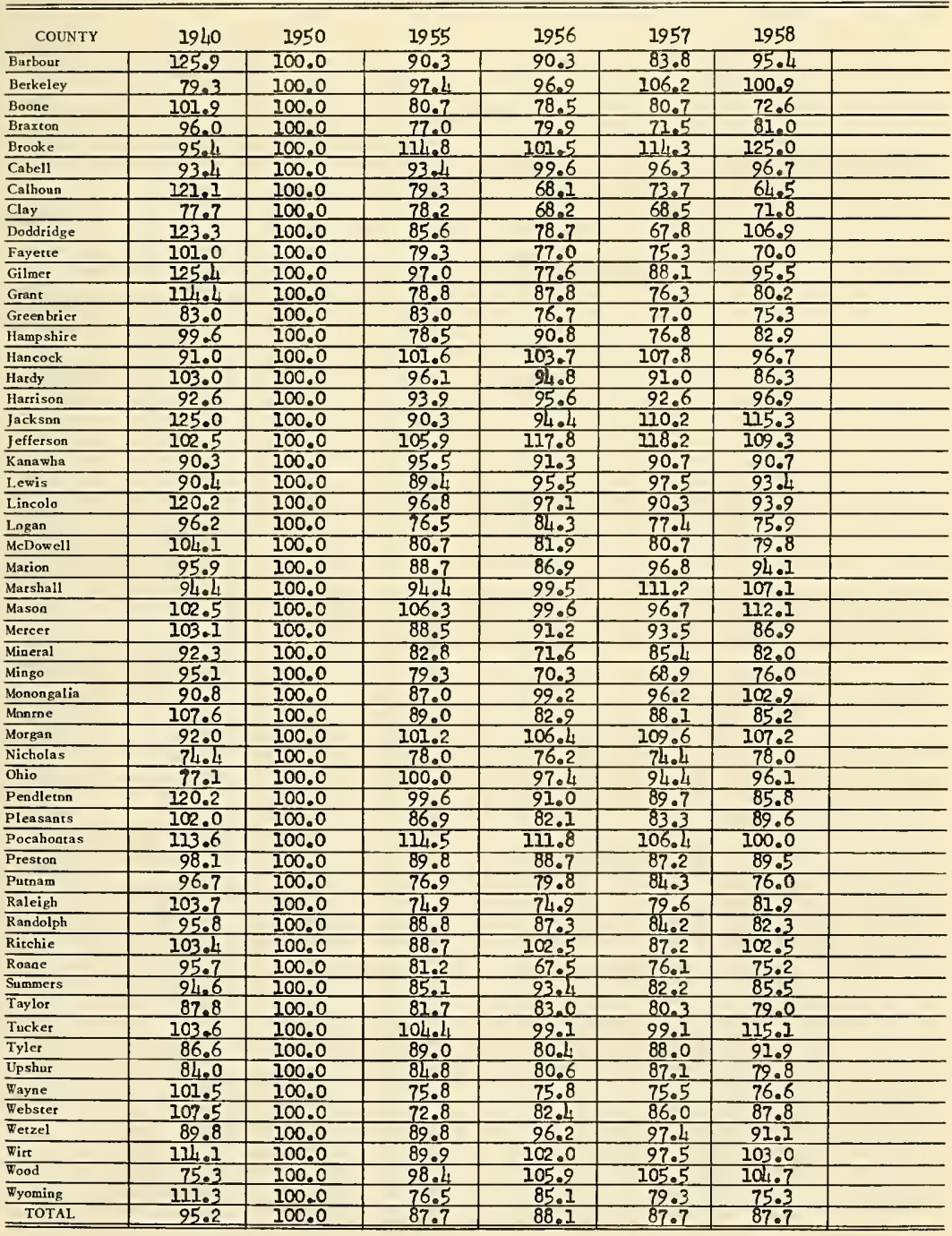

Section I

POPULATION AND

VITAL STATISTICS

W. Va. Unir.

Agr. Exp. Sta.

Bul. Na. 464

Page 13 
The number of deaths is taken, for the respective years, from Vital Statistics of the United States, publis hed by the United States Department of Health, Education, and Welfare or from photostatic copies (for recent years) of reports furnished by the West Virginia Department of Health. No adjustments were made on the reported number of deaths.

\section{Section 1 \\ POPULATION AND VITAL STATISTICS}

W. Va, Univ, Agr. Exp. Sto. Bul. No. 464

Page 14

\begin{tabular}{|c|c|c|c|c|c|c|c|}
\hline COUNTY & 1940 & 1950 & 1955 & 1956 & 1957 & 1958 & 1959 \\
\hline Barbour & 212 & 191 & 203 & 186 & 179 & 164 & 207 \\
\hline Berkeley & 324 & 312 & 319 & 332 & 373 & 298 & 31,5 \\
\hline Boone & 188 & 210 & 213 & 208 & 216 & 227 & 206 \\
\hline Braxton & 174 & 181 & 180 & 148 & 186 & 151 & 189 \\
\hline Brooke & 225 & 206 & 250 & 250 & 259 & 240 & 257 \\
\hline Cabell & 1,015 & 1,024 & 991 & 1,062 & 1,096 & 1,033 & 1,078 \\
\hline Calhoun & 111 & 105 & 83 & 87 & 88 & 87 & 85 \\
\hline Clay & 113 & 106 & 84 & 67 & 82 & 88 & 104 \\
\hline Doddridge & 90 & 123 & 93 & 95 & 88 & 76 & 100 \\
\hline Fayette & 705 & 637 & 614 & 611 & 608 & 616 & 576 \\
\hline Gilmer & 83 & 95 & 93 & 74 & 82 & 80 & 78 \\
\hline Grant & 87 & 63 & 84 & 69 & 65 & 67 & 75 \\
\hline Greenbrier & 387 & 377 & 322 & 340 & 357 & 353 & 359 \\
\hline Hampshire & 132 & 116 & 113 & 128 & 130 & 123 & 130 \\
\hline Hancock & 239 & 280 & 303 & 286 & 317 & 281 & 302 \\
\hline Hardy & 87 & 101 & 64 & 87 & 91 & 83 & 100 \\
\hline Harrison & 758 & 809 & $7 \longdiv { 4 8 }$ & 797 & 853 & 836 & 799 \\
\hline Jackson & 165 & 142 & 130 & 120 & 154 & 170 & 151 \\
\hline Jefferson & 228 & 195 & 211 & 196 & 209 & 210 & 212 \\
\hline Kanawha & 1,645 & 1,963 & 1,929 & 1,908 & 2,045 & 1,958 & 2,008 \\
\hline Lewis & 326 & 230 & 239 & 255 & 227 & 234 & 227 \\
\hline Lincoln & 198 & 181 & 160 & 151 & 182 & 149 & 188 \\
\hline Logan & 496 & 593 & 500 & 473 & 503 & 477 & 463 \\
\hline McDowell & 924 & 729 & 586 & 653 & 694 & 659 & 658 \\
\hline Marion & 688 & 682 & 664 & 663 & 698 & 734 & 700 \\
\hline Marshall & 455 & 364 & 339 & 365 & 360 & 385 & 372 \\
\hline Mason & 261 & 224 & 199 & 188 & 236 & 209 & 210 \\
\hline Mercer & 587 & 657 & 641 & 699 & 708 & 714 & 641 \\
\hline Mineral & 219 & 232 & 208 & 206 & $2 /, 6$ & 228 & 256 \\
\hline Mingo & 303 & 315 & 299 & 291 & 335 & 367 & 367 \\
\hline Monongalia & 467 & 506 & 512 & 1,84 & 513 & 525 & 535 \\
\hline Monroe & 110 & 135 & 131 & 135 & 124 & 144 & 107 \\
\hline Morgan & 89 & 94 & 89 & 104 & 109 & 94 & 93 \\
\hline Nicholas & 157 & 204 & 211 & 200 & 214 & 252 & 236 \\
\hline Ohio & 862 & 852 & 766 & 818 & 836 & 810 & 871 \\
\hline Pendleton & 98 & 65 & 78 & 69 & 82 & 71 & 80 \\
\hline Pleasants & 67 & 63 & 67 & 81 & 67 & 79 & 60 \\
\hline Pocahontas & 146 & 110 & 94 & 111 & 120 & 111 & 132 \\
\hline Preston & 312 & 265 & 232 & 271 & 254 & 286 & 266 \\
\hline Potnam & 140 & 156 & 160 & 161 & 156 & 165 & 189 \\
\hline Raleigh & 694 & 668 & 645 & 617 & 676 & 666 & 638 \\
\hline Randalph & 286 & 258 & 264 & 281 & 304 & 272 & 268 \\
\hline Ritchie & 159 & 167 & 164 & 146 & 145 & Ili4 & 140 \\
\hline Roane & 252 & 178 & 170 & 150 & 153 & 152 & 140 \\
\hline Summers & 207 & 179 & 189 & 182 & 179 & 182 & 158 \\
\hline Taylor & 209 & 176 & 195 & $19 ?$ & 205 & 227 & 213 \\
\hline Tucker & 121 & 118 & 106 & 95 & 115 & 101 & 103 \\
\hline Tyleq & 136 & 108 & 127 & 108 & 119 & 112 & 119 \\
\hline Upshur & 183 & 171 & 204 & 213 & 220 & 237 & 201 \\
\hline Wayne & 292 & 246 & 295 & 259 & 272 & 303 & 304 \\
\hline Webster & 120 & 132 & 102 & 113 & 124 & 133 & 134 \\
\hline Wetzel & 215 & 200 & 192 & 219 & 206 & 235 & 211 \\
\hline Wirt & 82 & 65 & 58 & 54 & 66 & 40 & 58 \\
\hline Wood & 616 & 658 & 688 & 733 & 729 & 824 & 765 \\
\hline Wyoming & 224 & 211 & 186 & 172 & 211 & 209 & 213 \\
\hline TOTAL & 17,669 & 17.428 & 16.787 & 16.968 & 17.856 & 17.665 & 17.677 \\
\hline
\end{tabular}


TABLE 4B. INDEX OF THE NUMBER OF DEATHS BY PLACE OF RESIDENCE

FOR THE COUNTIES OF WEST VIRGINIA, $1950=100$

\begin{tabular}{|c|c|c|c|c|c|c|c|}
\hline COUNZY & 1940 & 1950 & 1955 & 1956 & 1957 & 1958 & 1959 \\
\hline Barbour & 111.0 & 100.0 & 106.3 & 97.4 & 93.7 & 85.9 & 108.4 \\
\hline Berkeley & 103.8 & 100.0 & 102.2 & 106.4 & 119.6 & 95.5 & 110.6 \\
\hline Boone & 89.5 & 100.0 & 101.4 & 99.0 & 102.9 & 108.1 & 98.1 \\
\hline Braxton & 96.1 & 100.0 & 99.4 & 81.8 & 102.8 & 83.4 & 104.4 \\
\hline Brooke & 109.2 & 100.0 & 121.4 & 121.4 & 125.7 & 116.5 & 124.8 \\
\hline Cabell & 99.1 & 100.0 & 96.8 & 103.7 & 107.0 & 100.9 & 105.3 \\
\hline Calhoun & 105.7 & 100.0 & 79.0 & 82.9 & 83.8 & 82.9 & 81.0 \\
\hline Clay & 106.6 & 100.0 & 79.2 & 63.2 & 77.4 & 83.0 & 98.1 \\
\hline Doddridge & 73.2 & 100.0 & 75.6 & 77.2 & 71.5 & 61.8 & 81.3 \\
\hline Fayette & 110.7 & 100.0 & 96.4 & 95.9 & 95.4 & 96.7 & 90.4 \\
\hline Gilmer & 87.4 & 100.0 & 97.9 & 77.9 & 86.3 & 84.2 & 82.1 \\
\hline Grant & 138.1 & 100.0 & 133.3 & 109.5 & 103.2 & 106.3 & 119.0 \\
\hline Green brier & 102.7 & 100.0 & 85.4 & 90.2 & 94.7 & 93.6 & 95.2 \\
\hline Hampshire & 113.8 & 100.0 & 97.4 & 110.3 & 112.1 & 106.0 & 112.1 \\
\hline Hancock & 85.4 & 100.0 & 108.2 & 102.1 & 113.2 & 100.4 & 107.9 \\
\hline Hardy & 86.1 & 100.0 & 63.4 & 86.1 & 90.1 & 82.2 & 99.0 \\
\hline Harrison & 93.7 & 100.0 & 92.5 & 98.5 & 105.4 & 103.3 & 98.8 \\
\hline Jacksoa & 116.2 & 100.0 & 91.5 & 84.5 & 108.4 & 119.7 & 106.3 \\
\hline Jefferson & 116.9 & 100.0 & 108.2 & 100.5 & 107.2 & 107.7 & 108.7 \\
\hline Kanawha & 83.8 & 100.0 & 98.3 & 97.2 & 104.2 & 99.7 & 102.3 \\
\hline Lewis & 1.1.? & 100.0 & 103.9 & 110.9 & 98.7 & 101.7 & 98.7 \\
\hline Lincola & 109.4 & 100.0 & 88.4 & 83.4 & 100.6 & 82.3 & 103.9 \\
\hline Logao & 83.6 & 100.0 & 84.3 & 79.8 & 84.8 & 80.4 & 78.1 \\
\hline McDowell & 126.7 & 100.0 & 80.4 & 89.6 & 95.2 & 90.4 & 90.3 \\
\hline Marion & 100.9 & 100.0 & 97.4 & 97.2 & 102.3 & 107.6 & 102.6 \\
\hline Marshall & 725.0 & 100.0 & 93.1 & 100.3 & 98.9 & 105.8 & 102.2 \\
\hline Mason & 116.5 & 100.0 & 88.8 & 83.9 & 105.4 & 93.3 & 93.7 \\
\hline Mercer & 89.3 & 100.0 & 97.6 & 106.4 & 107.8 & 108.7 & 97.6 \\
\hline Mineral & 24.4 & 100.0 & 89.7 & 88.8 & 106.0 & 98.3 & 110.3 \\
\hline Mingo & 96.2 & 100.0 & 94.9 & 92.4 & 106.3 & 116.5 & 116.5 \\
\hline Monongalia & 92.3 & 100.0 & 101.2 & 95.7 & 101.4 & 103.8 & 105.7 \\
\hline Monroe & 81.5 & 100.0 & 97.0 & 100.0 & 91.9 & 106.7 & 79.3 \\
\hline Morgan & 94.7 & 100.0 & 94.7 & 110.6 & 116.0 & 100.0 & 98.9 \\
\hline Nicholas & 77.0 & 100.0 & 103.4 & 98.0 & 104.9 & 123.5 & 115.7 \\
\hline Ohio & 101.2 & 100.0 & 89.9 & 96.0 & 98.1 & 95.1 & 102.2 \\
\hline Pendleroo & 150.8 & 100.0 & 120.0 & 106.2 & 126.2 & 109.2 & 123.1 \\
\hline Pleasants & 106.3 & 100.0 & 106.3 & 128.6 & 106.3 & 125.4 & 95.2 \\
\hline Pocahootas & 132.7 & 100.0 & 85.5 & 100.9 & 109.1 & 100.9 & 120.0 \\
\hline Prestoa & 117.7 & 100.0 & 87.5 & 102.3 & 95.8 & 107.9 & 100.4 \\
\hline Putaam & 89.7 & 100.0 & 102.6 & 103.2 & 100.0 & 105.8 & 121.2 \\
\hline Raleigh & 1039 & 100.0 & 96.6 & 92.4 & 101.2 & 99.7 & 95.5 \\
\hline Randolph & 110.9 & 100.0 & 102.3 & 108.9 & 117.8 & 105.4 & 103.9 \\
\hline Ritchie & 95.2 & 100.0 & 98.2 & 87.4 & 86.8 & 86.2 & 83.8 \\
\hline Roane & 111.6 & 100.0 & 95.5 & 84.3 & 86.0 & 85.4 & 78.7 \\
\hline Summers & 175.6 & 100.0 & 105.6 & 101.7 & 100.0 & 101.7 & 88.3 \\
\hline Taylor & 118.7 & 100.0 & 110.8 & 111.9 & 116.5 & 125.6 & 121.0 \\
\hline Tucker & 102.5 & 100.0 & 89.8 & 80.5 & 97.5 & 85.6 & 87.3 \\
\hline Tyler & 125.9 & 100.0 & 117.6 & 100.0 & 110.2 & 103.7 & 110.2 \\
\hline Upshur & 107.0 & 100.0 & 119.3 & 124.6 & 122.8 & 138.6 & 117.5 \\
\hline Wayoe & 118.7 & 100.0 & 119.9 & 105.3 & 110.6 & 123.2 & 123.6 \\
\hline Webster & 90.9 & 100.0 & 77.3 & 85.6 & 93.9 & 100.8 & 101.5 \\
\hline Weczel & -107.5 & 100.0 & 96.0 & 109.5 & 103.0 & 117.5 & 105.5 \\
\hline Wirt & 126.2 & 100.0 & 89.2 & 83.1 & 101.5 & 61.5 & 89.2 \\
\hline Wood & 93.6 & 100.0 & 104.6 & 111.4 & 110.8 & 125.2 & 116.3 \\
\hline Wyoming & 106.2 & 100.0 & 88.2 & 81.5 & 100.0 & 99.1 & 100.9 \\
\hline TOTAL & 10104 & 100.0 & 96.3 & 97.4 & 102.5 & 101.4 & 101.4 \\
\hline
\end{tabular}

Section I

POPULATION AND VITAL STATISTICS

W. Va. Univ.

Agr. Exp. Sto.

Bul. No. 464

Page 15 
TABLE 4C. THE CRUDE DEATH RATE FOR THE COUNTIES OF WEST VIRG INIA

Data presented here were computed by dividing the data in Table $4 \mathrm{~A}$, this section, by the data in Table $2 \mathrm{~A}$, this section, and multiplying the results by 1,000 . This is standard procedure for developing crude death rate and may be interpreted as the number of deaths per 1,000 inhabitants of a given geographic area.

Section 1

POPULATION AND VITAL STATISTICS
W. Va. Univ.

Agr. Exp. Sta.

Bul. No. 464

Page 16




TABLE 4D. INDEX OF CRUDE DEATH RATE FOR THE COUNTIES OF WEST

VIRGINIA, $1950=100$

Changes indicated in this index may be the results of a change in the proportion of persons having entered the older age brackets due to increased longevity, or change in the proportion due to the migration influence.

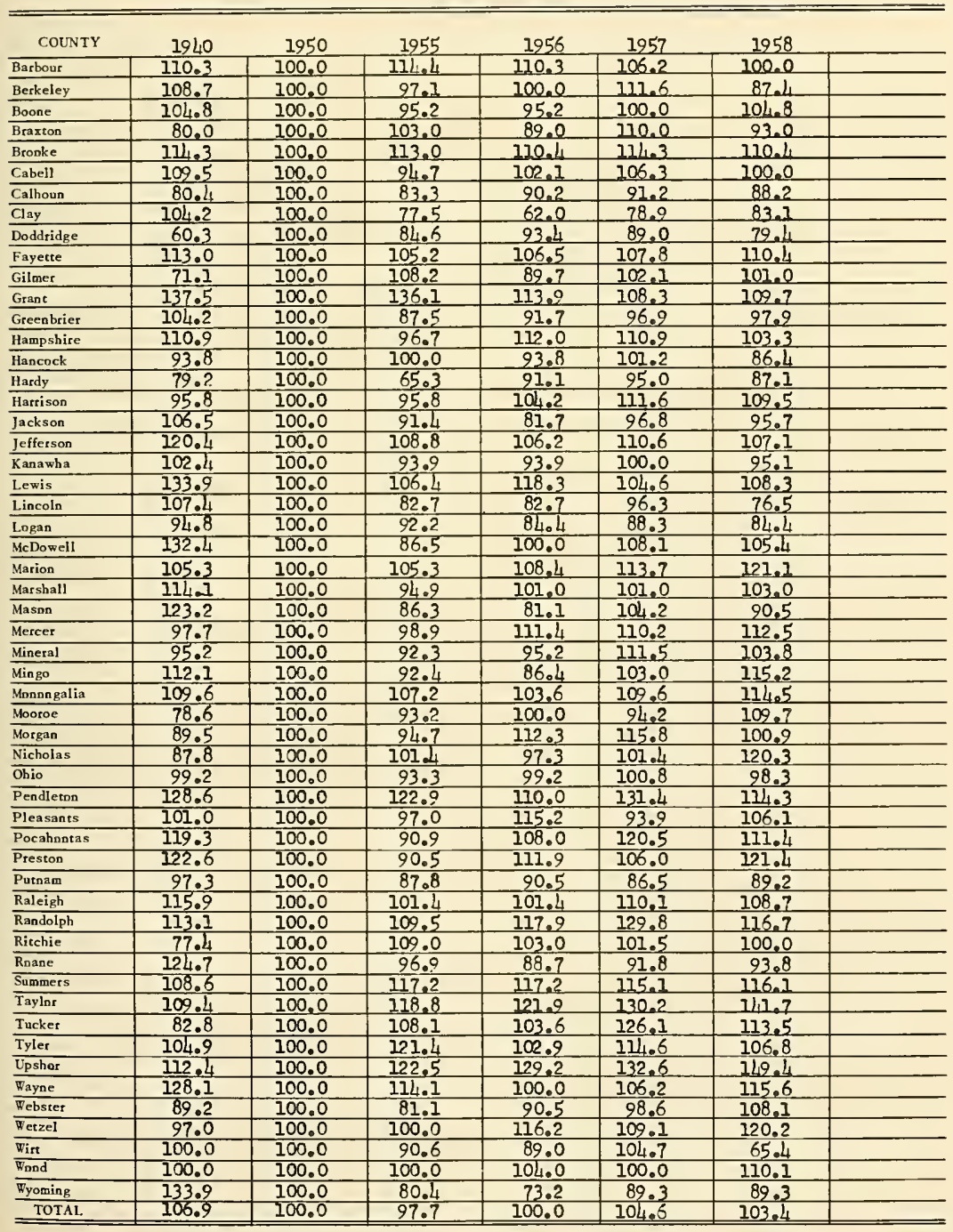

Section I

POPULATION AND VITAL STATISTICS

W. Va. Univ. Agr. Exp. Sta. Bul. No. 464

Page 17 



\section{Section II GOVERNMENT}

1 A Total Assessed Valuation (in Millions of Dollars) of all Properties of all Classes of the Counties of West Virginia ....

1B Total Assessed Valuation (in Millions of Dollars, Adjusted by the Wholesale Commodity Index) of all Properties of all Classes of the Counties of West Virginia ....

1C Index of Assessed Valuation (Adjusted by the Wholesale Commodity Index) of all Properties of all Classes of the Counties of West Virginia, $1950=100 \ldots$.

ID Index of Assessed Valuation (Adjusted by the Wholesale Commodity Index) of all Properties of all Classes of the Counties of West Virginia, $1930=100 \ldots$.

1E The Relationship Between Total Assessed Valuation of all Properties of all Classes and the Total Personal Income for the Counties-the Relationship is Expressed as the Number of Dollars of Assessed Valuation to the Number of Dollars of Personal Income

IF Index of the Relationship Between Total Assessed Valuation of all Properties of all $\mathrm{Cl}$ as s es and Total Personal Income for the Counties, $1950=100 \ldots$.

2A Total Expenditure (in Thousands of Dollars) Made by County Governments in West Virginia ....

2B Total Expenditures (in Thousands of Dollars, Adjusted by the Wholesale Commodity Index) Made by Counry Governments in West Virginia ....

2C Index of Total Expenditures (Adjusted by the Wholesale Commodity Index) Made by County Governments in West Virginia, $1950=10028$ 
TABLE IA. TOTAL ASSESSED VALUATION (IN MILLIONS OF DOLLARS) OF ALL PROPERTIES OF ALL CLASSES OF THE COUNTIES OF WEST VIRGINIA

The data presented in this table are taken from the West Virginia Blue Book, and the annual reports of the State Tax Commissioner of West Virginia. In this particular table, the 1930 data is added so as to give information previous to the adoption of the "Tax Limitation Amendment" in 1932.

Section II GOVERNMENT
W. Vo. Univ.

Agr. Exp. Sto. Bul. No. 464

Page 20

\begin{tabular}{|c|c|c|c|c|c|c|c|}
\hline COUNTY & & 1940 & 1950 & 1955 & 1958 & 1959 & 2960 \\
\hline Barbour & 16,600 & 12,218 & 19.333 & 18.961 & 22,611 & 19,203 & 370 \\
\hline Berkeley & 30,462 & 27,304 & 37.033 & 45,408 & 55,423 & 53,223 & 54,148 \\
\hline Boone & 28,807 & 23,290 & 30,256 & 41,520 & 47,146 & 49,567 & 50,809 \\
\hline Braxton & 16.527 & 14.287 & 19,273 & 22,910 & 29,205 & 26,287 & 25,378 \\
\hline Brooke & 39.788 & 39.739 & 52,971 & 62.508 & 70,480 & 65,848 & 66,251 \\
\hline Cabell & 127,843 & 130,011 & 201,394 & 244,579 & 300,448 & 350,702 & 350,056 \\
\hline Calhoun & 9,865 & 10,311 & 11,537 & 13,501 & 16,397 & 15,320 & 15,517 \\
\hline Clay & 13,315 & 9.257 & 14,117 & 15,837 & 17,250 & 15,858 & 16,360 \\
\hline Doddridge & 21,122 & 18,738 & 20,258 & 20,461 & 21,374 & 19,744 & 19,873 \\
\hline Fayette & 57,238 & 58,058 & 79,673 & 85,222 & 99,829 & 98,839 & 99,379 \\
\hline Gilmer & 14.463 & 13.524 & 16,739 & 17,204 & 18,496 & 17,164 & 17,603 \\
\hline Grant & 6,668 & 4,970 & 9,692 & 11,488 & 14,080 & 13,598 & 20 \\
\hline Green brier & 31,284 & 24,023 & 36,487 & 42,109 & 53,654 & 51,707 & 417 \\
\hline Hampshire & 10,092 & 9,736 & 16,321 & 20,165 & 22,596 & 21,762 & 22,033 \\
\hline Hancock & 26,044 & 37,892 & 58,950 & 99,983 & 115,715 & 104,880 & 105,668 \\
\hline Hardy & 5.777 & 5.743 & 10,421 & 14.657 & 17.721 & 18,640 & 18,611 \\
\hline Harrison & 120,399 & 100,876 & 144.154 & $162, L 19$ & 185,042 & 170.052 & 173.575 \\
\hline Jackson & 12.335 & $11,4,87$ & 21,983 & 29.571 & 54.506 & 51,345 & 582 \\
\hline Jefferson & 27,268 & 18,729 & 23,826 & 29,615 & 34,586 & 34,516 & 38,116 \\
\hline Kanawha & 218,609 & 232.925 & 329,383 & 418,639 & 533,772 & 556,958 & 579,858 \\
\hline Lewis & 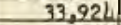 & 30,316 & 32,556 & 40,813 & 48,766 & 46,456 & 47.594 \\
\hline Lincoln & 17,958 & 18,183 & 23,683 & 26,104 & 26,310 & 27.929 & 27,876 \\
\hline Logan & 44,246 & 45,309 & 84,186 & 97,150 & 116,743 & 108,187 & 102,331 \\
\hline McDowell & 80,218 & 72.451 & 28,803 & 100,593 & 103,533 & 109,595 & 108,152 \\
\hline Marion & 100,346 & 70,749 & 93,624 & 108,914 & 152,466 & 140,109 & 140,901 \\
\hline Marshall & 51,101 & 40.594 & 56,949 & 69,883 & 103,723 & 116,693 & 118,636 \\
\hline Masan & 17.740 & 15,190 & 35,215 & 48,936 & 56,799 & 53,331 & 458 \\
\hline Mercer & 63.248 & 53,650 & 79,843 & 99,042 & 124,402 & 119,882 & 124,782 \\
\hline Minexal & 22,631 & 18.590 & 25,909 & 30,610 & 32,664 & 31,978 & 70 \\
\hline Mingo & 10,331 & 35.186 & 55.413 & 64.571 & 76,763 & 158 & 20 \\
\hline Monnogalia & 85,669 & 57.367 & 84.773 & 94,855 & 106,884 & 98,311 & 524 \\
\hline Montne & 10,210 & 8,868 & 12,451 & 11,013 & 17,403 & 17,346 & 17,504 \\
\hline Morgan & 14,516 & 12,083 & 14,173 & 16,583 & 19,379 & 19,081 & 511 \\
\hline Nicholas & 17,886 & 11,868 & 22,270 & 28,323 & 33,318 & 31,575 & 873 \\
\hline Ohin & 110,921 & 125,332 & 162,744 & 201,509 & 216,620 & 193,083 & 206,968 \\
\hline Pendleton & 5,719 & 4.985 & 8,092 & 11,376 & 12,737 & 395 & 966 \\
\hline Pleasants & 8.551 & 7.642 & 16,635 & 18.286 & 20,056 & 18,871 & 18,550 \\
\hline Pacahontas & 14.564 & 10,348 & 15,026 & 17,670 & 19,925 & 19,933 & 21,401 \\
\hline Preston & 28,346 & 22,179 & 38,262 & 49,223 & 55,018 & 53,210 & 53,510 \\
\hline Patnam & 15,371 & 17.352 & 23,159 & 32,980 & 45,6142 & 47,872 & 25 \\
\hline Raleigh & 49.366 & 47,721 & 80.695 & 99,586 & 102,117 & 102,502 & $1 a_{4}$ \\
\hline Randolph & 22.236 & 18,842 & 26,965 & 33,276 & 44,002 & 43,101 & 35 \\
\hline Ritchie & 24.736 & 20,416 & 22.612 & 23,907 & 26,487 & 24,557 & \\
\hline Roane & 27,361 & $22, \angle 125$ & 25,862 & 27,331 & 29,268 & 27.818 & \\
\hline Sammers & 27,481 & 15,923 & 21.790 & 22.686 & 25.522 & 991 & \\
\hline Taylor & $23,1,58$ & 18,954 & 23,957 & 28.525 & 31.057 & 28,805 & 58 \\
\hline Tucker & 9,702 & 7,755 & 9,648 & 10,835 & 13,022 & 13,388 & 755 \\
\hline Tyler & 16,138 & 14.173 & 17,034 & 19,420 & 23,616 & 19,385 & 362 \\
\hline Upshar & 15,283 & 12,342 & 19,776 & 25,558 & 33,822 & 32,190 & 32,638 \\
\hline Wayne & 39,460 & 35,550 & 10,329 & 63,157 & 66,085 & 67,192 & 69,164 \\
\hline Webater & 11,012 & 8.513 & 15,447 & 15,516 & 18,421 & 17.861 & 18,527 \\
\hline Wetzel & 30,421 & 27,716 & 36,413 & 39,263 & 44.803 & 50,987 & 51,654 \\
\hline Wirt & 5,572 & 4.457 & 5,951 & 6,406 & 6,898 & 6,360 & 67 \\
\hline Wood & 77.505 & 68.713 & 96,293 & 126,771 & 163,834 & 143,125 & 154,166 \\
\hline Wyoming & 28.539 & 28.533 & 50.750 & 57,882 & 70,970 & 71,603 & 70,877 \\
\hline TOTAL & $2,010,264$ & 1.840 .425 & $2,640,206$ & 3,188 & $3.879,476$ & $3,770,372$ & 328 \\
\hline
\end{tabular}


TABLE IB. TOTAL ASSESSED VALUATION (IN MILLIONS OF DOLLARS, ADJUSTED BY THE WHOLESALE COMMODITY INDEX) OF ALL PROPERTIES OF ALL CLASSES OF THE COUNTIES OF WEST VIRGINIA

Data presented here are taken from the West Virginia Blue Book or the annual reports of the State Tax Commissioner of West Virginia.

\begin{tabular}{|c|c|c|c|c|c|c|c|}
\hline COUNTY & 1930 & 1940 & 1950 & 1955 & 1958 & 1959 & 1960 \\
\hline Barbour & 29,590 & 23,911 & 18,751 & 17,128 & 18,960 & 16,083 & 16,223 \\
\hline Berkeley & 54.299 & 53,433 & 35.919 & 41,019 & 46,496 & 44.576 & 45,350 \\
\hline Boone & 51,349 & 45,577 & 29,346 & 37,507 & 39,552 & 41,513 & 42,554 \\
\hline Braxtoo & 29,460 & 27,958 & 18,694 & 20,696 & 24,500 & 22,016 & 21,255 \\
\hline Brooke & 70,923 & 77.766 & 51,378 & 56,466 & 59,128 & 55,149 & 55,487 \\
\hline Cabell & 227,884 & 254,424 & 195,339 & 220,939 & 252,054 & 293,720 & 293,179 \\
\hline Calhoun & 17,585 & 20,179 & 11,190 & 12,196 & 13,756 & 12,831 & 12,996 \\
\hline Clay & 23,734 & 18,116 & 13,692 & 14,306 & 14,472 & 13,281 & 13,702 \\
\hline Doddridge & 37,651 & 36,670 & 19,649 & 18,484 & 17.932 & 16,536 & 16,644 \\
\hline Fayette & 102,029 & 113,616 & 77,277 & 76,985 & 83,749 & 82,780 & 83,232 \\
\hline Gilmer & 25,781 & 26,466 & 16,236 & 15,541 & 15,517 & 14.375 & 14,743 \\
\hline Grant & 11,886 & 9,727 & 9,401 & 10,377 & 11,812 & 11,389 & 11,575 \\
\hline Greenbrier & 55,765 & 47,011 & 35,390 & 38,039 & 45,011 & 43,306 & 43,063 \\
\hline Hampshire & 17,989 & 19,053 & 15,830 & 18,216 & 18,956 & 18,226 & 18,453 \\
\hline Hancock & 46,124 & 74,153 & 57,177 & 90,319 & 97,076 & 87,839 & 88,499 \\
\hline Hardy & 10,298 & 11,239 & 10,108 & 13,241 & 14,867 & 15,612 & 15,587 \\
\hline Harrison & 214,615 & 197,409 & 139,820 & 146,720 & 155,237 & 142,422 & 145,373 \\
\hline Jackson & 21,988 & 22,479 & 21,322 & 26,713 & 45,727 & 43,003 & 45,714 \\
\hline Jefferson & 37,911 & 36,652 & 23,110 & 26,752 & 29,015 & 28,908 & 31,923 \\
\hline Kanawba & 389,677 & 469,521 & 319,479 & 378,175 & 447,795 & 466,453 & 485,642 \\
\hline Lewis & 60,471 & 59,326 & 31,577 & 36,868 & 40,911 & 38,907 & 39,861 \\
\hline Lincoln & 32,011 & 35,583 & 22,971 & 23,581 & 22,072 & 23,391 & 23,347 \\
\hline Logan & 78,870 & 88,667 & 81,655 & 87,760 & 97,939 & 90,609 & 85,704 \\
\hline McDawell & 142,991 & 141,782 & 95,832 & 90,870 & 86,856 & 91,786 & 90,580 \\
\hline Marioo & 178,870 & 138,453 & 90,809 & 98,387 & 127,908 & 117,344 & 118,008 \\
\hline Marshall & 91,089 & 79,439 & 55,236 & 63,128 & 87,016 & 97,733 & 99,360 \\
\hline Masnn & 31,622 & 29,725 & 34,156 & 44,206 & 47,651 & 44,665 & 46,447 \\
\hline Mercer & 112,742 & 104,991 & 77,442 & 89,469 & 104,364 & 100,404 & 104,508 \\
\hline Mineral & 40,340 & 36,380 & 25,130 & 27.651 & 27.403 & 26,782 & 27,278 \\
\hline Mingo & 71,891 & 68,858 & 53,746 & 58,329 & 64,398 & 63,198 & 63,333 \\
\hline Monongal ia & 152,708 & 112,265 & 82,224 & 85.687 & 89,668 & 82,338 & 81,678 \\
\hline Monroe & 18,200 & 17.355 & 12,077 & 12,658 & 14,600 & 14,527 & 14,660 \\
\hline Morgan & 25,875 & 23,646 & 13,747 & 14,980 & 16,257 & 15,981 & 16,425 \\
\hline Nichnlas & 31,882 & 23,226 & 21,600 & 25,585 & 27,951 & 26,444 & 26,694 \\
\hline Ohiv & 197,720 & 245,269 & 157,851 & 182,032 & 181,728 & 161,711 & 173,340 \\
\hline Peadletoo & 10,194 & 9,755 & 7,849 & 10,276 & 10,686 & 10,381 & 10,859 \\
\hline Pleasants & $15,2 \longdiv { 4 2 }$ & 14.956 & 16,135 & 16,519 & 16,825 & 15,805 & 15,536 \\
\hline Pncabontas & 25,961 & 20,250 & 14,575 & 15,962 & 16,716 & 16,694 & 17,924 \\
\hline Preston & 50,531 & 43,403 & 37,112 & 44,466 & 46,156 & 44,564 & 44,816 \\
\hline Pntasm & 27,399 & 33,957 & 22,463 & 29,792 & 38,290 & 40,094 & 42,567 \\
\hline Raleigh & 87,996 & 93,388 & 78,269 & 89,960 & 85,668 & 85,848 & 87,679 \\
\hline Raadolph & 39,636 & 36,873 & 26,154 & 30,060 & 36,913 & 36,098 & 38,137 \\
\hline Ritchie & 44,093 & 39,954 & 21,932 & 21,596 & 22,221 & 20,567 & 21,374 \\
\hline Rnane & 48,772 & 43,885 & 25,084 & 24,692 & 24,554 & 23,298 & 23,692 \\
\hline Summers & 31,160 & 31,160 & 21,134 & 20,493 & 21,411 & 20,931 & 20,979 \\
\hline Taylnr & 41,815 & 37,092 & 23,237 & 25,768 & 26,055 & 24,725 & 23.583 \\
\hline Tucker & 17,294 & 15,176 & 9,357 & 9,788 & 10,924 & 11,213 & 10,683 \\
\hline Tyler & 28,766 & 27,736 & 16,522 & 27,543 & 19,812 & 16,236 & 17,054 \\
\hline Upshnr & 27,242 & 24,152 & 19,181 & 23,088 & 28,433 & 26,960 & 27.335 \\
\hline Wayoe & 70,339 & 69,569 & 47,846 & 57,052 & 55,441 & 56,275 & 57,926 \\
\hline Webster & 19,629 & 16,659 & 14,982 & 14,043 & 15,454 & 14,959 & 15,517 \\
\hline Wetzel & 54,209 & 54,238 & 35,318 & 35,468 & 37,586 & 42,703 & 43,261 \\
\hline Wirt & 9,932 & 8,723 & 5,772 & 5,786 & 5,787 & 5,326 & 5,332 \\
\hline Wood & 138,155 & 134,527 & 93,398 & 114,517 & 137,445 & 119,870 & 129,117 \\
\hline Wyoming & 50,872 & 55,837 & 49,224 & 52,287 & 59,539 & 59,969 & 59,361 \\
\hline TOTAL & $3,583,358$ & 3,601, & $.560,724$ & $2,880,166$ & $3,204,259$ & $3,157,766$ & $3,225,149$ \\
\hline
\end{tabular}

Section II GOVERNMENT
W. Va. Univ.
Agr. Exp. Sta.
Bul. No. 464 
TABLE IC. INDEX OF ASSESSED VALUATION (AD JUSTED BY THE WHOLESALE COMMODITY INDEX) OF ALL PROPERTIES OF ALL CLASSES OF THE COUNTIES OF WEST VIRGINIA, $1950=100$

This index is based on the data presented in the preceding table, Table 1B, Section Il.

Section II GOVERNMENT

W. Va. Univ.

Agr. Exp. Sto.

Bol. Na. 464

Page 22

\begin{tabular}{|c|c|c|c|c|c|c|c|}
\hline COUNTY & 1930 & 1940 & 1950 & 1955 & 1958 & 1959 & 1960 \\
\hline Barbour & 757.8 & 127.5 & 100.0 & 97.3 & 101.2 & 85.8 & 86.5 \\
\hline Berkeley & 151.2 & 148.8 & 100.0 & 174.2 & 129.4 & 124.1 & 126.3 \\
\hline Boooe & 175.0 & 155.3 & 100.0 & 127.8 & 134.8 & $1,1.5$ & 145.0 \\
\hline Braxton & 157.6 & 149.6 & 100.0 & 110.7 & 131.1 & 117.8 & 113.7 \\
\hline Brooke & 138.0 & 151.4 & 100.0 & 109.9 & 115.1 & 107.3 & 108.0 \\
\hline Cabell & 116.7 & 130.2 & 100.0 & 113.1 & 129.0 & 150.4 & 150.1 \\
\hline Calhoun & 157.1 & 180.3 & 100.0 & 109.0 & 122.9 & 274.7 & 116.1 \\
\hline Clay & 173.3 & 132.3 & 100.0 & 104.5 & 105.7 & 97.0 & 100.1 \\
\hline Doddridge & 191.6 & 186.6 & 100.0 & 94.1 & 91.3 & 84.2 & 84.7 \\
\hline Fayette & 132.0 & 147.0 & 100.0 & 99.6 & 108.4 & 107.1 & 107.7 \\
\hline Gilmer & 158.8 & 163.0 & 100.0 & 95.7 & 95.6 & 88.5 & 90.8 \\
\hline Grant & 126.4 & 103.5 & 100.0 & 110.4 & 125.6 & 121.2 & 123.1 \\
\hline Greenbrier & 157.6 & 132.8 & 100.0 & 107.5 & 127.2 & 122.4 & 121.7 \\
\hline Hampshire & 113.6 & 120.4 & 100.0 & 115.1 & 119.7 & 115.1 & 116.6 \\
\hline Haocock & 81.2 & 129.7 & 100.0 & 158.0 & 169.8 & 153.6 & 154.8 \\
\hline Hardy & 101.9 & 111.2 & 100.0 & 131.0 & 147.1 & 154.4 & 154.2 \\
\hline Harrison & 153.5 & 141.2 & 100.0 & 104.9 & 111.0 & 101.9 & 104.0 \\
\hline Jacksoo & 103.1 & 105.4 & 100.0 & 125.3 & 214.5 & 201.7 & 214.4 \\
\hline Jeffersoo & 164.0 & 158.6 & 100.0 & 115.8 & 125.6 & 125.1 & 138.1 \\
\hline Kanawha & 122.0 & य1. & 100.0 & 118.4 & 140.2 & 146.0 & 152.0 \\
\hline Lewis & 191.5 & 187.9 & 100.0 & 116.8 & 129.6 & 123.2 & 126.2 \\
\hline Lincoln & 139.4 & 154.9 & 100.0 & 102.7 & 96.1 & 101.8 & 101.6 \\
\hline Logan & 96.6 & 108.6 & 100.0 & 107.5 & 119.9 & 111.0 & 105.0 \\
\hline McDowell & 149.2 & 147.9 & 100.0 & 94.8 & 90.6 & 95.8 & 94.5 \\
\hline Marioo & 197.0 & 152.5 & 100.0 & 108.3 & 140.9 & 129.2 & 130.0 \\
\hline Marshall & 164.9 & 143.8 & 100.0 & 114.3 & I57.5 & 176.9 & 179.9 \\
\hline Masnn & 92.6 & 87.0 & 100.0 & 129.4 & 139.5 & 130.8 & 136.0 \\
\hline Mercer & 145.6 & 135.6 & 100.0 & 115.5 & 134.8 & 129.6 & 135.0 \\
\hline Mineral & 160.5 & 144.8 & 100.0 & 110.0 & 109.0 & 106.6 & 108.5 \\
\hline Mingo & 133.8 & 128.1 & 100.0 & 108.5 & 119.8 & 117.6 & 99.4 \\
\hline Manongalia & 185.7 & 136.5 & 100.0 & 104.2 & 109.1 & 100.1 & 99.3 \\
\hline Mooroe & 150.7 & 143.7 & 100.0 & 104.8 & 120.9 & 720.3 & 121.4 \\
\hline Margan & 188.2 & 172.0 & 100.0 & 109.0 & 118.3 & 116.2 & 119.5 \\
\hline Nicholas & 147.6 & 107.5 & 100.0 & 118.4 & 129.4 & 122.4 & 123.6 \\
\hline Ohio & 125.3 & 155.4 & 100.0 & 115.3 & 115.1 & 102.4 & 109.8 \\
\hline Pendletoo & 129.9 & 124.3 & 100.0 & 130.9 & 136.1 & 132.3 & 138.3 \\
\hline Pleasants & 94.5 & 92.7 & 100.0 & 102.4 & 104.3 & 98.0 & 96.3 \\
\hline Pocahootas & 178.1 & 138.9 & 100.0 & 109.5 & 114.7 & 114.5 & 123.0 \\
\hline Prestoo & 136.2 & 117.0 & 100.0 & 119.8 & 124.4 & 120.1 & 120.8 \\
\hline Putoam & 222.0 & 151.2 & 100.0 & 132.6 & 170.5 & 178.5 & 189.5 \\
\hline Raleigh & 112.4 & 119.3 & 100.0 & 114.9 & 109.5 & 109.7 & 112.0 \\
\hline Randalph & 151.5 & 141.0 & 100.0 & 114.9 & 111.1 & 138.0 & 145.8 \\
\hline Ritchie & 201.0 & 182.2 & 100.0 & 98.5 & 101.3 & 93.8 & 97.5 \\
\hline Roane & 194.4 & 175.0 & 100.0 & 98.4 & 97.9 & 92.9 & 94.4 \\
\hline Sommers & 147.4 & 147.4 & 100.0 & 97.0 & 101.3 & 99.0 & 99.3 \\
\hline Taylor & 180.0 & 159.6 & 100.0 & 110.9 & 112.1 & 103.8 & 101.5 \\
\hline Tucket & 184.8 & 162.2 & 100.0 & 104.6 & 116.7 & 119.8 & 114.2 \\
\hline Tyler & 174.1 & 167.9 & 100.0 & 106.2 & 119.9 & 98.3 & 103.2 \\
\hline Upshar & 112.0 & 125.9 & 100.0 & 120.4 & 148.2 & 140.6 & 142.5 \\
\hline Wayoe & 147.0 & 145.4 & 100.0 & 119.2 & 115.9 & 117.6 & 121.1 \\
\hline Webster & 131.0 & 111.2 & 100.0 & 93.7 & 103.1 & 99.8 & 103.6 \\
\hline Wetzel & 153.5 & 153.6 & 100,0 & 100.4 & 106.4 & 120.9 & 122.5 \\
\hline Wirt & 172.1 & 151.1 & 100.0 & 100.3 & 100.3 & 92.3 & 92.4 \\
\hline Wood & 247.9 & 1) & 100.0 & 122.6 & 147.2 & 128.3 & 138.2 \\
\hline Wyoming & 103,3 & 113.4 & 100.0 & 106.2 & 121.0 & 121.8 & 120.6 \\
\hline TOTAL & 139.9 & 240.6 & 100.0 & 112.5 & 125.1 & 123.3 & 125.9 \\
\hline
\end{tabular}


TABLE 1D. INDEX OF ASSESSED VALUATION (ADJUSTED BY THE WHOLESALE COMMODITY INDEX) OF ALL PROPERTIES OF ALL CLASSES OF THE COUNTIES OF WEST VIRGINIA, $1930=100$

\begin{tabular}{|c|c|c|c|c|c|c|c|}
\hline COUNTY & 1930 & 1940 & 1950 & 1955 & 1958 & 1959 & 1960 \\
\hline Barbour & 100.0 & 80.8 & 63.4 & 57.9 & 64.1 & 54.4 & 54.8 \\
\hline Berkeley & 100.0 & 98.4 & 66.2 & 75.5 & 85.6 & 82.1 & 83.5 \\
\hline Boone & 100.0 & 88.8 & 57.2 & 73.0 & 77.0 & 80.8 & 82.9 \\
\hline Braxtoo & 100.0 & 94.9 & 63.5 & 70.3 & 83.2 & 74.7 & 72.1 \\
\hline Brooke & 100.0 & 109.6 & 72.4 & 79.6 & 83.4 & 77.8 & 78.2 \\
\hline Cabell & 100.0 & 111.6 & 85.7 & 97.0 & 110.6 & 128.9 & 128.7 \\
\hline Calhoun & 100,0 & 114.8 & 63.6 & 69.4 & 78.2 & 73.0 & 73.9 \\
\hline Clay & 100.0 & 76.3 & 57.7 & 60.3 & 61.0 & 56.0 & 57.7 \\
\hline Doddridge & 100.0 & 97.4 & 52.2 & 49.1 & 47.6 & 43.9 & 44.2 \\
\hline Fayette & 100.0 & 111.4 & 75.7 & 75.5 & 82.1 & 81.1 & 81.6 \\
\hline Gilmer & 100.0 & 102.7 & 63.0 & 60.3 & 60.2 & 55.8 & 57.2 \\
\hline Grant & 100.0 & 81.8 & 79.1 & 87.3 & 99.4 & 95.8 & 97.4 \\
\hline Greenbrier & 100.0 & 84.3 & 63.5 & 68.2 & 80.7 & 77.7 & 77.2 \\
\hline Hampshire & 100.0 & 105.9 & 88.0 & 101.3 & 105.4 & 101.3 & 102.6 \\
\hline Haocock & 100.0 & 159.7 & 123.2 & 194.6 & 209.1 & 189.2 & 190.6 \\
\hline Hardy & 100.0 & 109.1 & 98.2 & 128.6 & 144.4 & 151.6 & 151.4 \\
\hline Harrison & 100.0 & 92.0 & 65.1 & 68.4 & 72.3 & 66.4 & 67.7 \\
\hline Jacksoa & 100.0 & 102.2 & 97.0 & 121.5 & 208.0 & 195.6 & 207.9 \\
\hline Jeffersoa & 100.0 & 96.7 & 61.0 & 70.6 & 76.5 & 76.3 & 84.2 \\
\hline Kanawha & 100.0 & 120.5 & 82.0 & 97.0 & 114.4 & 119.7 & 124.6 \\
\hline Lewis & 100.0 & 98.1 & 52.2 & 61.0 & 67.7 & 64.3 & 65.9 \\
\hline Liacola & 100.0 & 111.2 & 71.8 & 73.7 & 69.0 & 73.1 & 72.9 \\
\hline Logaa & 100.0 & 112.4 & 103.5 & 111.3 & 124.2 & 114.9 & 108.7 \\
\hline McDowell & 100.0 & 99.2 & 67.0 & 63.5 & 60.7 & 64.2 & 63.3 \\
\hline Marioo & 100.0 & 77.4 & 50.8 & 55.0 & 71.5 & 65.6 & 66.0 \\
\hline MarshalI & 100.0 & 87.2 & 60.6 & 69.3 & 95.5 & 107.3 & 109.1 \\
\hline Mason & 100.0 & 94.0 & 108.0 & 139.8 & 150.7 & 141.2 & 146.9 \\
\hline Mercer & 100.0 & 93.1 & 68.7 & 79.4 & 92.6 & 89.1 & 92.7 \\
\hline Mineral & 100.0 & 90.2 & 62.3 & 68.5 & 67.9 & 66.4 & 67.6 \\
\hline Mingo & 100.0 & 95.8 & 74.8 & 81.8 & 89.6 & 87.9 & 88.1 \\
\hline Mooongalia & 100.0 & 73.5 & 53.8 & 56.1 & 58.7 & 53.9 & 53.5 \\
\hline Mooroe & 100.0 & 95.4 & 66.4 & 69.5 & 80.2 & 79.8 & 80.5 \\
\hline Morgao & 100.0 & 91.4 & 53.1 & 57.9 & 62.8 & 61.8 & 63.5 \\
\hline Nicholas & 100,0 & 72.8 & 67.7 & 80.2 & 87.7 & 82.9 & 83.7 \\
\hline Obio & 100.0 & 124.0 & 79.8 & 92.1 & 91.9 & 81.8 & 87.7 \\
\hline Pendletoo & 100.0 & 95.7 & 77.0 & 100.8 & 104.8 & 101.8 & 106.5 \\
\hline Pleasaots & 100.0 & 98.1 & 105.9 & 108.4 & 110.4 & 103.7 & 101.9 \\
\hline Pocahoatas & 100.0 & 78.0 & 56.1 & 61.5 & 64.4 & 64.3 & 69.0 \\
\hline Prestoo & 100.0 & 85.9 & 73.4 & 88.0 & 93.1 & 88.2 & 88.7 \\
\hline Potoam & 100.0 & 123.9 & 82.0 & 208.7 & 139.7 & 246.3 & 255.4 \\
\hline Raleigh & 100.0 & 106.1 & 88.9 & 102.2 & 97.4 & 97.6 & 99.6 \\
\hline Raodolph & 100,0 & 93.0 & 66.0 & 75.8 & 93.1 & 91.1 & 96.2 \\
\hline Ritchie & 100.0 & 90.6 & 49.7 & 49.0 & 50.4 & 46.6 & 48.5 \\
\hline Roaae & 100.0 & 90.0 & 51.4 & 50.6 & 50.3 & 47.8 & 48.6 \\
\hline Summers & 100.0 & 100.0 & 67.8 & 65.8 & 68.7 & 67.2 & 67.3 \\
\hline Taylor & 100,0 & 88.7 & 55.6 & 61.6 & 62.3 & $57 . ?$ & 56.4 \\
\hline Tucker & 100.0 & 87.8 & 54.2 & 56.6 & 63.2 & 64.8 & 61.8 \\
\hline Tyler & 100,0 & 96.4 & 57.4 & 61.0 & 68.9 & 56.4 & 59.3 \\
\hline Upshur & 100.0 & 88.7 & 70.4 & 84.8 & 104.4 & 99.0 & 100.3 \\
\hline Wayne & 100.0 & 98.9 & 68.0 & 81.1 & 78.8 & 80.0 & 82.4 \\
\hline Webster & 100.0 & 84.9 & $76 . \overline{3}$ & 71.5 & 78.7 & 76.2 & 79.1 \\
\hline Wetzel & 100.0 & 100.1 & 65.2 & 65.4 & 69.3 & 78.8 & 79.8 \\
\hline Wirt & 100.0 & 87.8 & 58.1 & 58.3 & 58.3 & 53.6 & 53.7 \\
\hline Wood & 100.0 & 97.4 & 67.6 & 82.9 & 99.5 & 86.8 & 93.5 \\
\hline Wyoming & 100.0 & 109.8 & 96.8 & 102.8 & 117.0 & 117.9 & 116.7 \\
\hline TOTAL & 100.0 & 100.5 & 71.5 & 80.4 & 89.4 & 88.1 & 90.0 \\
\hline
\end{tabular}

Section II GOVERNMENT
W. Ya. Univ.

Agr. Exp. Sto.

Bul. No. 464

Page 23 
TABLE IE. THE RELATIONSHIP BETWEEN TOTAL ASSESSED VALUATION OF ALL PROPERTIES OF ALL CLASSES AND THE TOTALPERSONAL INCOME FOR THE COUNTIES - THE RELATIONSHIP IS EXPRESSED AS THE NUMBER OF DOLLARS OF ASSESSED EVALUATION TO THE NUMBER OF DOLLARS OF PERSONAL INCOME

Data presented here were computed by dividing the data in Table 1A, Section II, by the data in Table 1A, Section VIII. Personal income data by counties for 1930 are apparently not available.

Section II GOVERNMENT

W. Va. Univ. Agr, Exp. Sta. Bul. No. 464

Page 24

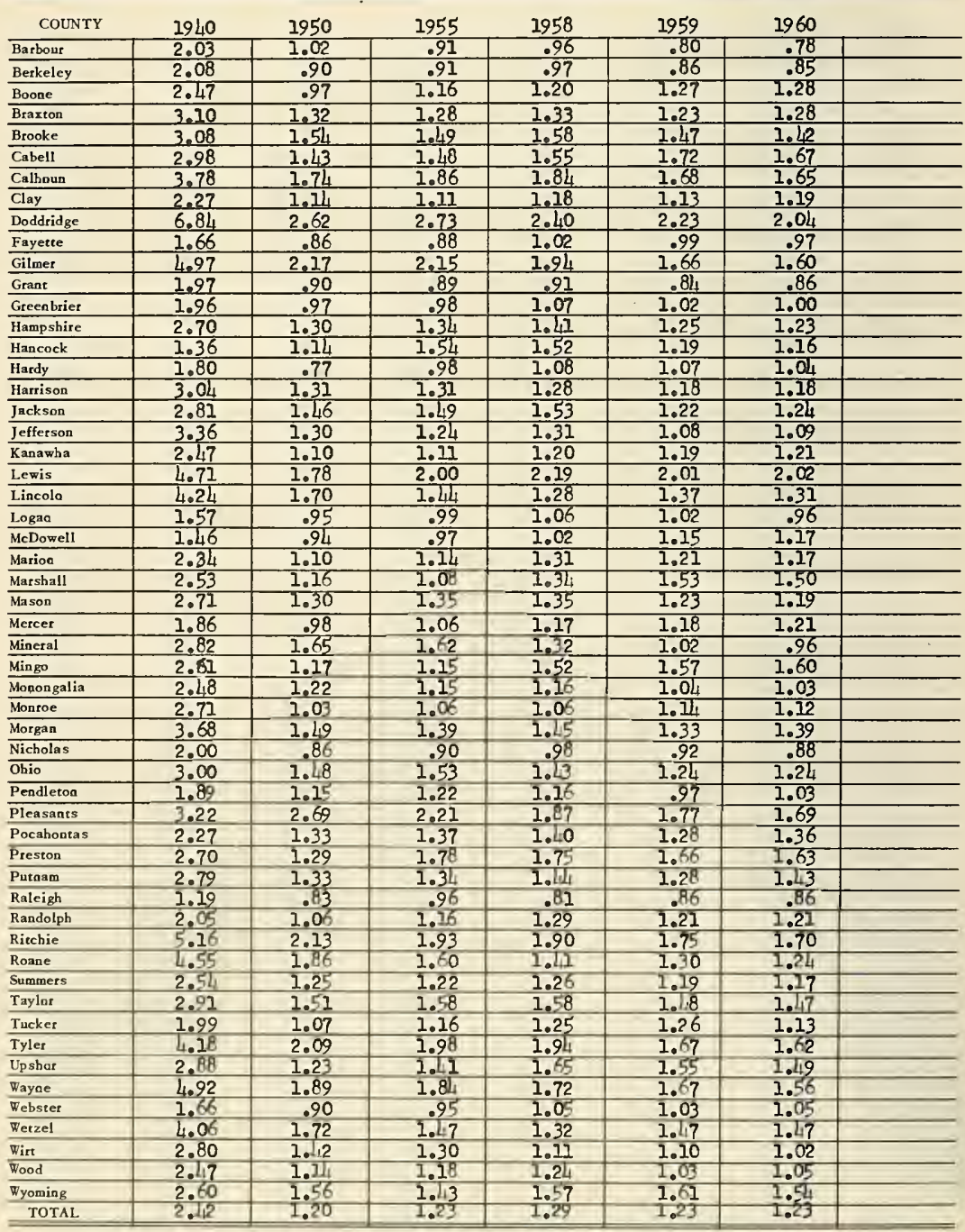


This index was prepared from the data presented in the preceding table, Table 1E. Section II.

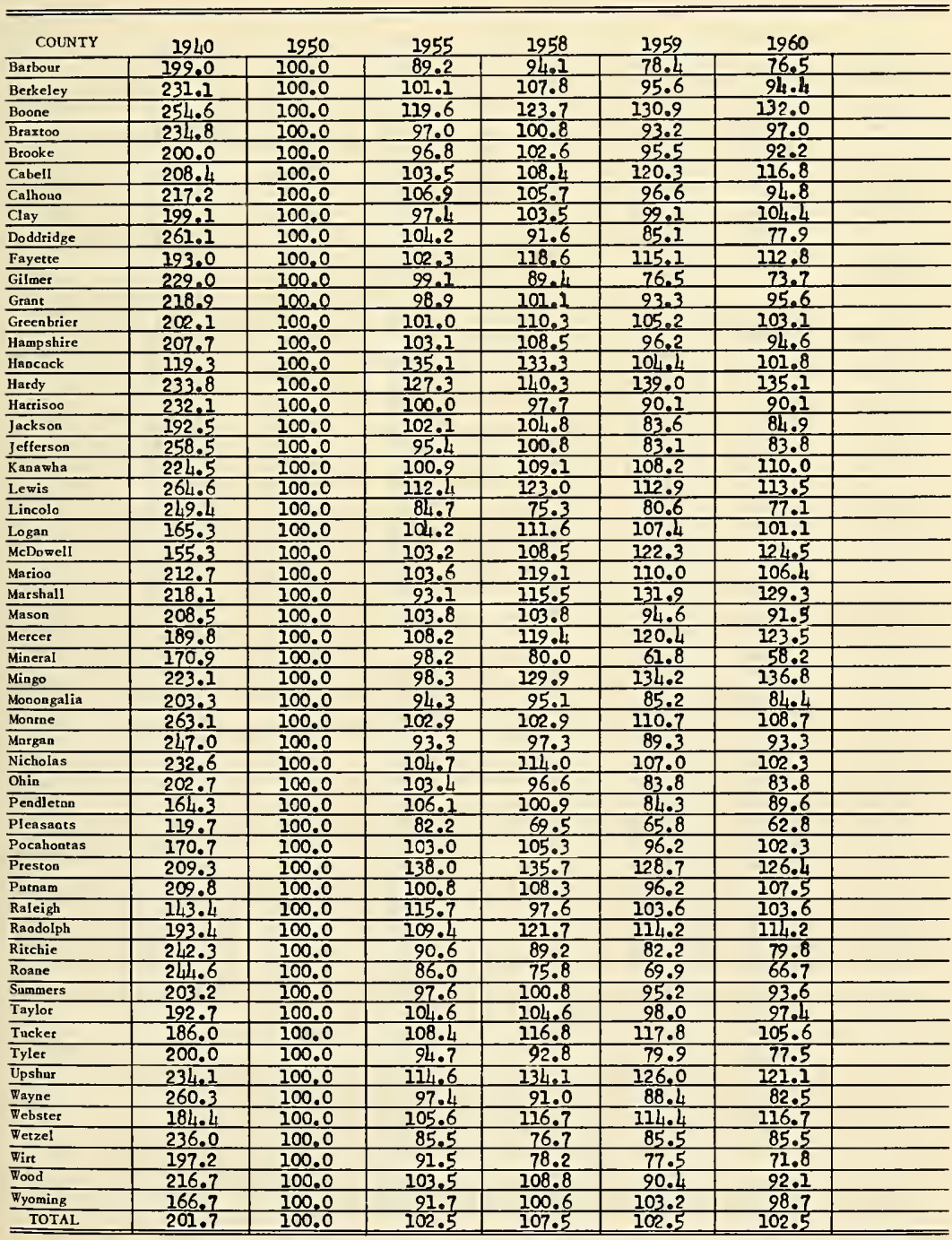

Section II GOVERNMENT
W. Va. Univ.

Agr. Exp. Sto. Bul. No. 464

Page 25 
Data in this table are based upon two sources. They are Report of Trend in Costs of Marketing Ordinary Functions of County Govemment in West Virginia for the Twenty-Two Year Period 1937-1958, published on August 16, 1958 by the West Virginia Chamber of Commerce, and Municipal and County Budgets in West Virginia, 1958-1960, written by Claude J. Davis, Eugene R. Elkins, and Paul E. Kidd and published by the West Virginia University Bureau for Government Research.

Section II GOVERNMENT

\begin{tabular}{|c|c|c|c|c|c|c|c|}
\hline COUNTY & 1940 & 1950 & 1955 & 2957 & 1958 & 1959 & 1960 \\
\hline Barbour & 47.9 & 81.8 & 93.5 & 99.28 & 311.8 & 118.2 & 111.6 \\
\hline Berkeley & 100.5 & 152.2 & 204.2 & $216.7 \times$ & 236.3 & 277.2 & 266 . \\
\hline Boone & 105.7 & 153.2 & 198.5 & 224.1 & 271.3 & 295.7 & 287.9 \\
\hline Braxton & 48.0 & 78.4 & 105.7 & 110.7 & 127.8 & 153.0 & 146.8 \\
\hline Brooke & 107.2 & 159.1 & 229.3 & $254.6 \times$ & 260.4 & 302.2 & 304.7 \\
\hline Cahell & 445.5 & 659.0 & 956.4 & $995.8 \pm$ & $1,006.7$ & 963.9 & $1,209.2$ \\
\hline Calhoun & 44.5 & 45.0 & 57.3 & 63.9 & 75.6 & 89.4 & 87.3 \\
\hline Clay & 40.7 & 53.3 & 75.9 & 81.5 & 99.0 & 87.6 & 97.5 \\
\hline Doddridge & 64.0 & 79.7 & 104.3 & 104.2 & 110.5 & 109.5 & 102.6 \\
\hline Fayetre & 231.4 & 360.1 & 468.6 & 488.2 견 & 517.9 & 592.1 & 575.5 \\
\hline Gilmer & 42.2 & 45.4 & 65.7 & 69.3 & 94.5 & 103.5 & 85.1 \\
\hline Grant & 18.7 & 37.8 & 41.8 & 47.0 & 45.8 & 222.8 & 264.9 \\
\hline Green brier & 80.2 & 138.3 & 189.5 & $217.2 \times$ & 257.6 & 279.9 & 283.2 \\
\hline Hampshire & 37.0 & 55.3 & 74.3 & 77.08 & 72.5 & 89.4 & 256.1 \\
\hline Haacock & 130.5 & 210.0 & 357.4 & $431.0 \mathrm{x}$ & 448.1 & 471.8 & 473.6 \\
\hline Hardy & 17.2 & 39.4 & 500.0 & 58.9 & 61.0 & 65.3 & 73.6 \\
\hline Harrison & 311.6 & 506.9 & 580.9 & 651.6 & 733.8 & 823.0 & 848.6 \\
\hline Jacksoa & 36.9 & 77.1 & 99.5 & 113.14 & 184.1 & 284.0 & 377.5 \\
\hline Jeffersoa & 60.5 & 87.0 & 118.5 & 131.2 & $11,1.2$ & 158.9 & 163.0 \\
\hline Kanawha & 843.4 & $1,291.6$ & $1,683.9$ & $2,094,3$ & $2,108,6$ & $2,350.0$ & $2,760,3$ \\
\hline Lewis & 94.6 & 101.0 & 112.4 & 163.5 & 188.8 & 225.9 & 245.4 \\
\hline Lincoln & 84.4 & 112.0 & 158.1 & 136.9 & 146.7 & 112.5 & 153.8 \\
\hline Logan & 180.8 & 375.0 & 458.8 & 529.7 & 559.7 & 602.0 & 574.3 \\
\hline McDowell & 340.3 & 453.2 & 543.2 & 499.1 & 628.5 & 631.3 & 637.5 \\
\hline Marion & 260.8 & 365.2 & 574.8 & $582.2=$ & 656.5 & 784.2 & 639.4 \\
\hline Marshall & 151.4 & 181.4 & 244.6 & 471.0 & 439.0 & 414.6 & 373.8 \\
\hline Mason & 49.2 & 133.5 & 230.0 & $246.9 \times$ & 257.0 & 278.2 & 289.8 \\
\hline Mercer & 198.0 & 321.2 & 465.3 & 471.4 & 533.5 & 579.6 & $6 I_{4.9}$ \\
\hline Mineral & 67.0 & 91.3 & 126.8 & 137.4 & 198.6 & 208.7 & 791.4 \\
\hline Mingo & 134.2 & 253.3 & 302.2 & 316.6 & 382.9 & 406.1 & 413.6 \\
\hline Moaongalia & 210.3 & 285.2 & 414.9 & $461.5=$ & 492.6 & 501.4 & 473.8 \\
\hline Monroe & 28.5 & 56.9 & 51.4 & 58.33 & 57.8 & 72.4 & 73.7 \\
\hline Morgao & 37.5 & 65.0 & 70.2 & 98.37 & 109.3 & 105.4 & 99.6 \\
\hline Nicholas & 51.2 & 84.4 & 138.0 & 149.5 & 161.4 & 174.5 & 170.5 \\
\hline Ohio & 378.8 & 467.7 & 640.9 & $721.2=$ & 741.5 & 768.6 & $1,031.3$ \\
\hline Pendleton & 15.8 & 38.3 & 47.2 & $58.3=$ & 61.0 & 69.3 & 71.9 \\
\hline Pleasaots & 25.1 & 49.4 & 82.0 & 92.9 & 105.4 & 98.7 & 107.0 \\
\hline Pocahontas & 35.7 & 53.5 & 78.9 & 96.0 & 91.4 & 88.3 & 89.3 \\
\hline Preston & 98.7 & 135.1 & 220.4 & 238.8 & 240.9 & 260.1 & 276.4 \\
\hline Putnam & 62.5 & 84.7 & 129.0 & $\coprod_{4} 6.8$ & 254.4 & 250.0 & 245.6 \\
\hline Raleigh & 483.3 & 385.9 & 550.4 & 604.64 & 578.2 & 565.5 & 612.4 \\
\hline Randolpb & 73.4 & 103.7 & 243.7 & 167.6 & 205.0 & 270.7 & 234.4 \\
\hline Ritchie & 71.7 & 103.3 & 98.6 & 123.13 & 131.9 & 250.8 & 141.8 \\
\hline Roane & 69.0 & 88.6 & 135.4 & $150.2 *$ & 161.2 & 161.4 & 168.6 \\
\hline Sommers & 61.2 & 87.7 & 105.1 & 124.7 여 & 120.0 & 123.4 & 143.1 \\
\hline Taylor & 67.0 & 201.4 & 178.4 & $149 \cdot 4$ & 153.3 & 165.0 & 153.7 \\
\hline Tucker & 39.4 & 44.9 & 51.0 & 69.24 & 67.4 & 68.8 & 71.0 \\
\hline Tylet & 48.5 & 64.5 & 68.3. & 76.0 & 84.7 & 94.5 & 90.1 \\
\hline Upsbur & 43.2 & 72.4 & 109.0 & 115.2 & 147.3 & 154.1 & 178.9 \\
\hline Wayoe & 143.4 & 222.6 & 258.5 & 338.8 & 371.9 & 388.0 & 418.5 \\
\hline Webster & 37.5 & 67.7 & 81.8 & 71.39 & 78.2 & 81.7 & 90.5 \\
\hline Wetzel & 107.7 & 147.8 & 182.4 & 188.1म & 266.4 & 240.8 & 280.8 \\
\hline Wirt & 19.3 & 19.1 & 25.9 & 31.4 和 & 35.1 & 39.6 & 38.2 \\
\hline Wood & 233.2 & 326.7 & 515.0 & 588.2 & 642.9 & 672.3 & 692.3 \\
\hline wyoming & 720.8 & 203.5 & 269.1 & 380.5 & 461.6 & 409.7 & 403.9 \\
\hline TOTAL & $6,935.9$ & $10,051.4$ & $13,646.3$ & $15,337.6$ & $16,776.4$ & $18,025.5$ & $19,206.6$ \\
\hline
\end{tabular}

w. Yo. Univ. Agr. Exp. Sto. Bul. No. 464

Page 26 
TABLE 2B. TOTAL EXPENDITURES (IN THOUSANDS OF DOLLARS, ADJUSTED BY THE WHOLE-SALE COMMODITY INDEX) MADE BY COUNTY GOVERNMENTS IN WEST VIRGINIA

The data presented here are based on those contained in the preceding table, Table $2 \mathrm{~A}$, Section II.

\begin{tabular}{|c|c|c|c|c|c|c|c|}
\hline COUNTY & 1940 & 1950 & 1955 & 1957 & 1958 & 1959 & 1960 \\
\hline Barbour & 94.3 & 83.1 & 84.9 & 85.4 & 94.2 & 99.0 & 93.5 \\
\hline Berkeley & 197.8 & 154.7 & 185.5 & 186.0 & 199.1 & 232.2 & 223.1 \\
\hline Boone & 208.1 & 155.7 & 180.3 & 192.9 & 228.6 & 247.7 & 241.1 \\
\hline Braxton & 94.5 & 79.7 & 96.0 & 95.3 & 107.7 & 128.1 & 122.9 \\
\hline Brooke & 211.0 & 161.7 & 208.3 & 219.1 & 219.4 & 253.1 & 255.2 \\
\hline Cabell & 877.0 & 669.7 & 868.7 & 857.0 & 848.1 & 807.3 & $1,012.7$ \\
\hline Calhoun & 87.6 & 45.6 & 52.0 & 55.0 & 63.7 & 74.9 & 73.1 \\
\hline Clay & 78.9 & 54.2 & 68.9 & 70.1 & 83.4 & 73.4 & 81.7 \\
\hline Doddridge & 126.0 & 81.0 & 94.7 & 89.7 & 93.1 & 91.7 & 85.9 \\
\hline Fayette & 455.5 & 366.0 & 425.6 & 420.1 & 436.3 & 495.9 & 482.0 \\
\hline Gilmer & 83.1 & 46.1 & 59.7 & 59.6 & 79.6 & 86.7 & 71.3 \\
\hline Grant & 36.8 & 38.4 & 38.0 & 40.4 & 38.6 & 186.6 & 221.9 \\
\hline Green brier & 157.9 & 110.5 & 772.1 & 186.9 & 217.0 & 234.4 & 237.2 \\
\hline Hampshire & 72.8 & 56.2 & 67.5 & 66.3 & 61.1 & 74.9 & 214.5 \\
\hline Hancock & 256.9 & 213.4 & 324.6 & 370.9 & 377.5 & 395.1 & 396.6 \\
\hline Hardy & 33.9 & 40.0 & 45.4 & 50.7 & 51.4 & 54.7 & 61.6 \\
\hline Harrison & 613.4 & 515.1 & 527.6 & 560.8 & 618.2 & 689.3 & 710.7 \\
\hline Jackson & 72.6 & 78.3 & 90.4 & 123.4 & 155.1 & 237.9 & 265.9 \\
\hline Jeffersoo & 119.1 & 88.4 & 107.6 & 112.9 & 119.0 & 133.1 & 136.5 \\
\hline Kanawha & $1,660.2$ & $1,321.6$ & 1.529 .4 & $1,802.3$ & $1,776.4$ & $1,968.2$ & $2,311.8$ \\
\hline Lewis & 186.2 & 102.6 & 129.3 & 140.7 & 159.1 & 189.2 & 205.5 \\
\hline Lincola & 166.1 & 113.7 & 143.6 & 117.8 & 123.6 & 119.3 & 128.8 \\
\hline Logan & 355.9 & 381.1 & 416.7 & 455.9 & 471.5 & 504.2 & 481.0 \\
\hline McDowell & 669.9 & 460.6 & 493.4 & 429.5 & 529.5 & 528.7 & 533.9 \\
\hline Marion & 513.4 & 371.1 & 522.1 & 501.0 & 553.1 & 656.8 & 535.5 \\
\hline Marshall & 298.0 & 184.3 & 222.2 & 353.7 & 369.8 & 347.2 & 313.1 \\
\hline Masoa & 96.7 & 135.7 & 208.9 & 212.5 & 216.5 & 233.0 & 242.7 \\
\hline Mercer & 389.8 & 326.4 & 422.6 & 405.7 & 449.5 & 485.4 & 515.0 \\
\hline Mineral & 1319 & 92.8 & 115.2 & 118.2 & 167.3 & 174.8 & 160.3 \\
\hline Mingo & 264.2 & 257.4 & 274.5 & 272.5 & 322.6 & 340.1 & 346.4 \\
\hline Monongalia & 414.0 & 289.8 & 376.8 & 397.2 & 415.0 & 419.9 & 396.8 \\
\hline Montoe & 56.1 & 57.8 & 46.7 & 50.2 & 48.7 & 60.6 & 61.7 \\
\hline Morgan & 73.8 & 66.1 & 63.8 & 84.6 & 92.1 & 88.3 & 83.4 \\
\hline Nicholns & 100.8 & 85.8 & 125.3 & 128.7 & 136.0 & 146.1 & 142.8 \\
\hline Ohio & 745.7 & 475.3 & 582.1 & 620.7 & 624.7 & 643.7 & 863.7 \\
\hline Pendletnn & 31.1 & 38.9 & 42.9 & 50.2 & 51.4 & 58.0 & 60.2 \\
\hline Pleasants & 49.4 & 50.2 & 74.5 & 79.9 & 88.8 & 82.7 & 89.6 \\
\hline Pocahontas & 70.3 & 54.4 & 71.7 & 82.6 & 77.0 & 74.0 & 74.8 \\
\hline Preston & 194.3 & 137.3 & 200.2 & 205.5 & 202.9 & 217.8 & 231.5 \\
\hline Putnam & 123.0 & 86.1 & 117.1 & 126.3 & 214.3 & 209.4 & 205.7 \\
\hline Raleigh & 951.4 & 392.2 & 499.9 & 520.3 & 487.1 & 473.6 & 512.9 \\
\hline Randolph & 141.5 & 105. & 130.5 & 139.1 & 172.7 & 176.5 & 196.3 \\
\hline Ritchie & 140.9 & 105.0 & 89.6 & 105.9 & 111.1 & 126.3 & 118.8 \\
\hline Roane & 135.8 & 90.0 & 123.0 & 129.3 & 135.8 & 135.2 & 141.2 \\
\hline Summers & 120.5 & 89.1 & 95.5 & 98.2 & 101.0 & 103.4 & 119.8 \\
\hline Taylor & 131.9 & 103.0 & 162.0 & 128.6 & 129.1 & 138.2 & 728.7 \\
\hline Tucker & 77.6 & 45.6 & 46.2 & 59.6 & 56.8 & 57.6 & 59.5 \\
\hline Tyler & 95.5 & 65.5 & 61.9 & 65.4 & 71.4 & 79.1 & 75.5 \\
\hline Upshur & 85.0 & 73.6 & 99.0 & 99.1 & 124.1 & 129.1 & 149.8 \\
\hline Wayne & 282.3 & 226.2 & 234.8 & 291.6 & 313.3 & 325.0 & 350.5 \\
\hline Wehster & 73.8 & 68.8 & 74.3 & 61.4 & 65.9 & 68.4 & 75.8 \\
\hline Wetzel & 212.0 & 14. 1 & 165.7 & 161.9 & 224.4 & 201.7 & 235.2 \\
\hline Wirt & 38.0 & 19.4 & 23.5 & 27.0 & 29.6 & 33.2 & 32.0 \\
\hline Wood & 459.1 & 332.0 & 467.8 & 506.2 & $5\lfloor 7.6$ & 563.1 & 579.8 \\
\hline Wyoming & 237.8 & 206.8 & 244.4 & 327.5 & 388.9 & 343.1 & 338.3 \\
\hline TOTAL & $13,653.9$ & 10.211 .8 & $12,394.6$ & 13.292 .0 & 13.133 .4 & $15,096.7$ & $16,085.9$ \\
\hline
\end{tabular}

Section 11

GOVERNMENT
W. Vo. Univ.

Agr. Exp. Sto.

Bul. Na. 464 
TABLE 2C. INDEX OF TOTAL EXPENDITURES (AD JUSTED BY THE WHOLESALE COMMODITY INDEX) MADE BY COUNTY GOVERNMENTS IN WEST

VIRGINIA, $1950=100$

This index was prepared from the data presented in the pre-

ce ding table, Table 2B, Section II.

Section II GOVERNMENT

W. Ya. Univ.

Agr. Exp. Sta.

Bul. Na. 464

Page 28

\begin{tabular}{|c|c|c|c|c|c|c|c|}
\hline COUNTY & 1940 & 1950 & 1955 & 1957 & 1958 & 1959 & 1960 \\
\hline Basbour & 113.5 & 100.0 & 102.2 & 102.8 & 113.4 & 119.1 & 112.5 \\
\hline Berkeley & 127.9 & 100.0 & 112.9 & 120.2 & 128.7 & 150.1 & 144.2 \\
\hline Boone & 133.7 & 100.0 & 115.8 & 123.9 & 246.8 & 159.1 & 154.8 \\
\hline Braxton & 118.6 & 100.0 & 120.5 & 119.6 & 235.1 & 160.7 & 154.2 \\
\hline Brooke & 130.5 & 100.0 & 128.8 & 135.5 & $135 . ?$ & 156.5 & 157.8 \\
\hline Cabell & 131.0 & 100.0 & $129 . ?$ & 128,0 & 126.6 & 120.5 & 151.2 \\
\hline Calhoun & 192.1 & 100,0 & 114.0 & 120.6 & 139.7 & 164.3 & 160.3 \\
\hline Clay & 7.5 .6 & 100.0 & 127.1 & 129.3 & 153.9 & 135.4 & 150.7 \\
\hline Doddridge & 155.6 & 100.0 & 116.9 & 110.7 & 114.9 & 113.2 & 106.0 \\
\hline Fayette & 124.5 & 100.0 & 116.3 & 774.8 & 119.2 & 235.5 & 131.7 \\
\hline Gilmer & 180.3 & 100.0 & 129.5 & 129.3 & 172.7 & 188.1 & 154.7 \\
\hline Grant & 95.8 & 100.0 & 99.0 & 105.2 & 100.5 & 485.9 & 577.9 \\
\hline Green brier & 112.0 & 100,0 & 122.5 & 133.0 & 154.4 & 166.8 & 168.8 \\
\hline Hampshire & 129.5 & 100.0 & 120.1 & 118.0 & 108.7 & 133.3 & 381.7 \\
\hline Hancock & 120.4 & 100.0 & 152.1 & 173.8 & 176.9 & 185.1 & 185.8 \\
\hline Hardy & 84.8 & 100.0 & 113.5 & 126.8 & 128.5 & 136.8 & 154.0 \\
\hline Harrison & 119.1 & 100.0 & 102.4 & 108.9 & 120.0 & 133.8 & 138.0 \\
\hline Jackson & 92.7 & 100.0 & 115.5 & 157.6 & 198.1 & 303.8 & 339.6 \\
\hline Jefferson & 134.7 & 100.0 & $121 . ?$ & 127.7 & 134.6 & 150.6 & 154.4 \\
\hline Kanawha & 126.5 & 100.0 & 116.5 & 137.3 & 135.3 & 149.9 & 176.1 \\
\hline Lewis & 181.5 & 100,0 & 126.0 & 137.1 & 155.1 & 184.4 & 200.3 \\
\hline Lincoln & 146.1 & 100.0 & 126.3 & 103.6 & 108.7 & 104.9 & 113.3 \\
\hline Logan & 93.4 & 100.0 & 109.3 & 119.6 & 123.7 & 132.3 & 126.2 \\
\hline McDowell & 145.4 & 100.0 & 107.1 & 93.2 & 115.0 & 114.8 & 115.9 \\
\hline Marioo & 138.3 & 100.0 & 140.7 & 135.0 & 249.0 & 177.0 & 144.3 \\
\hline Marshall & 161.7 & 100.0 & 120.6 & 191.9 & 200.7 & 188.4 & 169.9 \\
\hline Mason & 71.3 & 100.0 & 153.9 & 156.6 & 159.5 & 171.0 & 178.6 \\
\hline Mercer & 119.4 & 100.0 & 129.5 & 124.3 & 137.7 & 148.7 & 157.8 \\
\hline Mineral & $1 / 12.7$ & 100.0 & $12 / . .7$ & $127 . / 1$ & 180.3 & 188.4 & 172.7 \\
\hline Mingo & 102.6 & 100.0 & 106.6 & 105.9 & 125.3 & 132.1 & 134.6 \\
\hline Monongalia & 142.9 & 100.0 & 130.0 & 137.1 & 113.2 & 144.9 & 136.9 \\
\hline Monroe & 97.1 & 100.0 & 80.8 & 86.9 & 81.3 & 104.8 & 106.7 \\
\hline Morgan & 171.6 & 100.0 & 96.5 & 128.0 & 139.3 & 133.6 & 126.2 \\
\hline Nicholas & 117.5 & 100.0 & 346.0 & 150.0 & 158.5 & 170.3 & 166.4 \\
\hline Ohio & 156.9 & 100.0 & 122.5 & 130.6 & 131.4 & 135.4 & 181.7 \\
\hline Pendleton & 79.9 & 100.0 & 110.3 & 129.0 & 132.1 & 149.1 & 154.8 \\
\hline Pleasants & 98.4 & 100.0 & 148.4 & 159.2 & 176.9 & 164.7 & 178.5 \\
\hline Pocahootas & 129.2 & 100.0 & 131.8 & 151.8 & 141.5 & 136.0 & 137.5 \\
\hline Prestoo & 141.5 & 100.0 & 145.8 & 149.7 & 147.8 & 158.6 & 168.6 \\
\hline Potoam & 142.9 & 100.0 & 136.0 & 146.7 & 248.9 & 243.2 & 238.9 \\
\hline Raleigh & 242.6 & 100.0 & 127.5 & 132.7 & $124 \cdot 2$ & 120.6 & 130.8 \\
\hline Randolph & 137.1 & 100.0 & 123.8 & 132.0 & 163.9 & 167.5 & 186.2 \\
\hline Ritchie & 134.2 & 100.0 & 85.3 & 100.9 & 205.8 & 120.3 & 113.1 \\
\hline Roane & 150.9 & 100.0 & 136.7 & 143.7 & 150.9 & 150.2 & 156.9 \\
\hline Summers & 135.2 & 100.0 & 107.2 & 110.2 & 113.4 & 116.0 & 134.5 \\
\hline Taylor & 128.1 & 100.0 & 157.3 & 124.9 & 125.3 & $13 / .2$ & 125.0 \\
\hline Tucker & 170.2 & 100.0 & 101.3 & 130.7 & 124.6 & 126.3 & 130.5 \\
\hline Tyler & 145.8 & 100.0 & 94.5 & 99.8 & 109.0 & 120.8 & 115.3 \\
\hline Upshur & 115.5 & 100,0 & 134.5 & 134.6 & 168.6 & 175.4 & 203.8 \\
\hline Wayne & 124.8 & 100.0 & 103.8 & 128.9 & 138.5 & 143.7 & 155.0 \\
\hline Webster & 107.3 & 100.0 & 108.0 & 89.2 & 95.8 & 99.4 & 110.2 \\
\hline Wetzel & 147.1 & 100.0 & 115.0 & 112.4 & 155.7 & 140.0 & 163.2 \\
\hline Wirt & 195.9 & 100.0 & 121.1 & 139.2 & 152.6 & 171.1 & 164.9 \\
\hline Wood & 138.3 & 100.0 & 140.9 & 152.5 & 163.1 & 169.6 & 174.6 \\
\hline Wyoming & 115.0 & 100.0 & 118.2 & 158.4 & 188.1 & 165.9 & 163.6 \\
\hline TOTAL & 133.7 & 100.0 & 121.3 & 129.2 & 138.4 & 147.8 & 157.5 \\
\hline
\end{tabular}




\section{WELfARE}

1A The Total Amounts (in Thousands of Dollars) for the Welfare Programs as Allocated, in the Annual Reports, to the Counties by the State Department of Public Assistance ....

1B The Total Amonats (in Thousands of Dollars Adjusted by Wholesale Commodity Index) for the Welfare Programs as Allocated, in the Annual Reports, to the Counties by the State Department of Public Assistance ....

1C Index of the Total Amounts (Adjusted by the Wholesale Commodity Index) for the Welfare Programs as Allocated, in the Annual Reports, to the Counties by the State Department of Public Assistance, $1950=100 \quad \ldots$.

ID A Comparison Between the Total Expenditures for Welfare in the Counties of West Virginia and the Total Personal Income of the Counties of West Virginia: Total Expenditures for Welfare is Represented as Percentages of the Total Personal Income ....

2A The Total Amounts (in Thousands of Dollars) of Transfer Payments of all Public Welfare Programs as Allocated, in the Annual Reports, to the Counties by the State Department of Public Assistance...

2B The Total Amounts (in Thousands of Dollars Adjusted by the Wholesale Commodity Index) of Transfer Payments of all Public Welfare Programs as Allocated, in the Annual Reports, to the Counties by the State Department of Public Assistance ....

2C Index of the Total Amounts (Adjusted by the Wholesale Commodity Index) of Transfer Payments of all Public Welfare Programs as Allocated, in the Annual Reports, to the Counties by the State Department of Public Assistance, $1950=100 \quad \ldots$.

$3 A$ The Total Amounts (in Thousands of Dollars) of Transfer Payments Through the Program of Old Age Assistance to Recipients in the Counties of West Virginia ....

3B The Total Amounts (in Thousands of Dollars Adjusted by the Wholesale Commodity Index) of Transfer Payments Through the Program of Old Age Assistance to Recipients in the Counties of West Virginia $\ldots$.

3C Index of The Amounts of Transfer Payments (Adjusted by the Wholesale Commodity Index) in the Old Age Assistance Program in the Counties of West Virginia, $1950=100 \quad \ldots$.

4A The Amounts (in Thousands of Dollars) of Transfer Payments Paid Througb the Programs of Aid fot Dependent Children to Recipients in the Counties of West Virginia ....

4B The Amounts (in Thousands of Dollars Adjusted by the Wholesale Commodity lndex) of Transfer Payments Paid Thtough the Program of Aid for Dependent Children to Recipients in the Counties of West Virginia ....

4C Index of the Amounts of Transfet Payments (Adjusted by the Wholesale Commodity Index) in the Aid for Dependent Children Program in the Counties of West Virginia, $1950=100 \quad \ldots \ldots$ 
The amounts listed below contain all the transfer payments of the federal, state, and local governments and administrative and casework programs allocated to the counties.

Some state and federal funds, in the amount of four million dollars (1958), are not allocated as a budget procedure to the counties. No value has been assigned to assistance received in the form of commodities, nor are amounts expended by private welfare groups included. To obtain a comprehensive view of welfare programs in the counties, the additional sources should be taken into account.
Section III

WELFARE

W. Va. Univ.

Agr. Exp. Sta.

Bul. No. 464

Page 30

\begin{tabular}{|c|c|c|c|c|c|c|c|}
\hline COUNTY & $1939-40$ & $1949-50$ & $1954-55$ & $1955-56$ & $1957-58$ & $1958-59$ & $1959-60$ \\
\hline$\overline{\text { Barbour }}$ & 137 & 445 & 499 & 452 & L61 & 466 & 469 \\
\hline Berkeley & 87 & 182 & 224 & 198 & 224 & 256 & 303 \\
\hline Boone & 71 & 286 & 677 & 608 & 699 & 731 & 747 \\
\hline Braxtoo & 107 & 617 & 675 & 623 & 644 & 671 & 691 \\
\hline Brooke & 97 & $1 \longdiv { 3 }$ & 167 & 144 & 164 & 186 & 202 \\
\hline Cabell & 362 & 614 & 711 & 655 & 851 & 951 & 1,040 \\
\hline Calhoun & 61 & 293 & 195 & 193 & 235 & $2 ब 4$ & 284 \\
\hline Clay & 88 & 385 & 550 & 486 & 540 & 579 & 578 \\
\hline Doddridge & 59 & 196 & 191 & 150 & 168 & 183 & 183 \\
\hline Fayette & 294 & 570 & 1,299 & 1,263 & 1,459 & 1,593 & 1,720 \\
\hline Gilmer & 62 & 226 & 313 & 286 & 290 & 304 & 307 \\
\hline Graot & 54 & 101 & 153 & 132 & 150 & 150 & 168 \\
\hline Greenbrier & 122 & 664 & 756 & 656 & 598 & 637 & 660 \\
\hline Hampshire & 80 & 173 & 229 & 198 & 212 & 232 & 255 \\
\hline Hancock & 72 & 120 & 154 & 144 & 171 & 184 & 195 \\
\hline Hardy & 60 & 136 & 169 & 153 & 176 & 193 & 273 \\
\hline Harrison & 262 & 378 & 408 & 389 & 382 & 415 & 417 \\
\hline Jackson & 87 & 247 & 324 & 290 & 310 & 340 & 340 \\
\hline Jefferson & 89 & 125 & 149 & 148 & 183 & 209 & 229 \\
\hline Kanawha & 677 & 1,559 & 3,439 & $3,4,60$ & 3,560 & 3.554 & 3,467 \\
\hline Lewis & 79 & 385 & 533 & 505 & 558 & 599 & 655 \\
\hline Lincoln & 139 & 54 & 812 & 737 & 879 & 961 & 1,035 \\
\hline Logan & 181 & 574 & 1,591 & 1,472 & 1,706 & 1,933 & 2,048 \\
\hline McDowell & 277 & 753 & 1.695 & 1,638 & 1,885 & 2,270 & 2,488 \\
\hline Marion & 211 & 473 & 529 & 471 & 531 & 588 & 597 \\
\hline Marshall & 196 & 41 & 462 & 437 & 435 & 461 & 507 \\
\hline Mason & 124 & 276 & 371 & 340 & 385 & 413 & 423 \\
\hline Merces & 229 & 698 & 1,250 & 1,276 & 1,540 & 1,788 & 2,110 \\
\hline Mineral & 111 & 187 & 280 & 271 & 279 & 296 & 310 \\
\hline Mingo & 179 & 847 & 1,248 & 1,111 & 1,282 & 1,450 & 1,583 \\
\hline Mooongalia & 197 & 375 & 476 & 420 & 476 & 490 & 491 \\
\hline Monroe & 72 & 254 & 354 & 310 & 350 & 360 & 406 \\
\hline Morgaa & 66 & 106 & 113 & 100 & 108 & 131 & 153 \\
\hline Nicholas & 134 & 405 & 659 & 598 & 640 & 677 & 725 \\
\hline Obio & 271 & 526 & 645 & 546 & 590 & 640 & 694 \\
\hline Pendlecon & 42 & 145 & 226 & 200 & 212 & 223 & 235 \\
\hline Pleasants & 47 & 105 & 125 & 114 & 120 & 126 & 131 \\
\hline Pocahootas & 67 & 231 & 249 & 245 & 253 & 263 & 282 \\
\hline Preston & 179 & 421 & 437 & 371 & 356 & 371 & 369 \\
\hline Putnam & 109 & 317 & 424 & 387 & 416 & 444 & 438 \\
\hline Raleigh & 269 & 749 & 1,443 & 1,322 & 1,265 & 1,342 & 1,476 \\
\hline Randolph & 199 & 473 & 603 & 610 & 619 & 642 & 743 \\
\hline Ritchie & 112 & 270 & 242 & 231 & 256 & 280 & 292 \\
\hline Roane & 96 & 155 & 288 & 293 & 354 & 409 & $L 76$ \\
\hline Summers & 91 & 450 & 814 & 730 & 763 & 848 & 933 \\
\hline Taylor & 107 & 261 & 246 & 223 & 232 & 237 & 235 \\
\hline Tucker & 88 & 300 & 326 & 320 & 288 & 299 & 331 \\
\hline Tyler & 75 & 256 & 365 & 333 & 345 & 364 & 378 \\
\hline Upshas & 124 & 310 & 410 & 410 & 482 & 538 & 599 \\
\hline Wayoe & 183 & 927 & 1,196 & 1,127 & 1,268 & 1,372 & 1,485 \\
\hline Webster & 107 & 377 & 672 & 674 & 607 & 643 & 718 \\
\hline Wetzel & 150 & 414 & 542 & 465 & 452 & 467 & 497 \\
\hline Wirt & 45 & 112 & 118 & 112 & 112 & 119 & 121 \\
\hline Wood & 313 & 794 & 1,000 & 953 & 912 & 968 & 1,036 \\
\hline Tyoming & 128 & 416 & 697 & 635 & 758 & 872 & 1,012 \\
\hline TOTAL & 7.225 & 21,781 & 32,723 & 30,615 & 33,191 & 35.983 & 38,481 \\
\hline
\end{tabular}


TABLE IB. THE TOTAL AMOUNTS (IN THOUSANDS OF DOLLARS, ADJUSTED BY THE WHOLESALE COMMODITY INDEX) FOR THE WELFARE PROGRAMS AS ALLOCATED, IN THE ANNUAL REPORTS, TO THE COUNTIES BY THE STATE DEPARTMENT OF PUBLIC ASSISTANCE

The data presented in this table were compiled from the preceding table, Table 1A, Section Ill.

\begin{tabular}{|c|c|c|c|c|c|c|c|}
\hline COUNTY & $1939-40$ & $1949-50$ & $1954-55$ & $1955-56$ & $1957-58$ & $1958-59$ & $1959-60$ \\
\hline Barbour & 270 & 452 & 453 & 403 & 386 & 390 & 393 \\
\hline Berkeley & 171 & 185 & 203 & 176 & 189 & 214 & 254 \\
\hline Boone & 140 & 291 & 615 & 542 & 589 & 612 & 626 \\
\hline Braxton & 211 & 627 & 613 & 555 & 543 & 562 & 579 \\
\hline Brooke & 191 & 3145 & 152 & 128 & 138 & 156 & 169 \\
\hline Cabell & 713 & 624 & 646 & 584 & 717 & 796 & 871 \\
\hline Calhoun & 120 & 298 & 177 & 172 & 198 & 221 & 238 \\
\hline Clay & 173 & 391 & 500 & 433 & 455 & 485 & 484 \\
\hline Doddridge & 116 & 199 & 173 & 134 & 142 & 153 & 153 \\
\hline Fayette & 579 & 579 & 1,180 & 1,126 & 1,229 & 1,334 & $1,4 \sqrt{1}$ \\
\hline Gilmer & 122 & 230 & 284 & 255 & 24 & 255 & 257 \\
\hline Grant & 106 & 103 & 139 & 118 & 126 & 126 & 141 \\
\hline Greeabrier & 240 & 675 & 687 & 585 & 504 & 534 & 553 \\
\hline Hampshire & 157 & 176 & 208 & 176 & 179 & 194 & 214 \\
\hline Hancock & Iद2 & 122 & 140 & 128 & 144 & 154 & 163 \\
\hline Hardy & 118 & 138 & 153 & 136 & 118 & 162 & 178 \\
\hline Harrison & 516 & 384 & 371 & 347 & 322 & 348 & 349 \\
\hline Jackson & 171 & $25 I$ & 294 & 258 & 261 & 285 & 285 \\
\hline Jefferson & 175 & 127 & 135 & 132 & 154 & 175 & 192 \\
\hline Kanawha & 1,333 & 1,584 & 3,124 & 3,084 & 2,999 & 2,977 & 2,904 \\
\hline Lewis & 156 & 391 & 484 & 450 & 470 & 502 & 549 \\
\hline Lincoln & 274 & 553 & 738 & 657 & 741 & 805 & 867 \\
\hline Logan & 356 & 583 & 1,445 & 1,312 & 1,437 & 1,619 & 1,715 \\
\hline McDowell & 545 & 765 & 1,540 & 1,460 & 1,588 & 1,901 & 2.084 \\
\hline Marion & 415 & 481 & 480 & 420 & 447 & 492 & 500 \\
\hline Marshall & 386 & 448 & 420 & 389 & 366 & 386 & 425 \\
\hline Mason & 24 & 280 & 337 & 303 & 324 & 346 & 354 \\
\hline Mercer & 451 & 709 & 1,135 & 1,137 & 1,297 & 1,497 & 1,767 \\
\hline Mineral & 218 & 190 & 254 & 242 & 235 & 248 & 260 \\
\hline Mingo & 352 & 855 & 1,134 & 990 & 1,080 & 1,214 & 1,326 \\
\hline Mbaoogalia & 388 & 381 & 432 & 374 & 401 & 410 & 411 \\
\hline Monroe & 112 & 258 & 322 & 276 & 295 & 302 & 340 \\
\hline Morgan & 130 & 108 & 103 & 89 & 91 & 110 & 128 \\
\hline Nicholas & 264 & 412 & 599 & 533 & 539 & 567 & 607 \\
\hline Ohis & 533 & 535 & 586 & 487 & 497 & 536 & 581 \\
\hline Pendleton & 83 & 147 & 205 & 178 & 179 & 187 & 197 \\
\hline Pleasants & 93 & 107 & 114 & 102 & 101 & 106 & 110 \\
\hline Pocahoatas & 132 & 235 & 226 & 218 & 213 & 220 & 236 \\
\hline Preston & 352 & 428 & 397 & 331 & 300 & 311 & 309 \\
\hline Putnam & 215 & 322 & 385 & 345 & 350 & 372 & 367 \\
\hline Raleigh & 530 & 761 & 1,311 & 1,178 & 1,066 & 1,124 & 1,236 \\
\hline Randolph & 392 & 481 & 548 & 544 & 521 & 538 & 622 \\
\hline Ritchie & 220 & 274 & 220 & 206 & 216 & 234 & 215 \\
\hline Roane & 189 & 158 & 262 & 261 & 298 & 343 & 399 \\
\hline Summers & 179 & 457 & 739 & 651 & 61,3 & 710 & 781 \\
\hline Taylor & 211 & 265 & 223 & 199. & 195 & 198 & 197 \\
\hline Tucker & 173 & 305 & 296 & 285 & 243 & 250 & 277 \\
\hline Tyler & 148 & 260 & 332 & 297 & 291 & 305 & 317 \\
\hline Upsher & 24l & 315 & 372 & 365 & $L 06$ & 451 & 502 \\
\hline Wayne & 360 & 942 & 1,086 & 1,004 & 1,068 & 1,149 & 1,244 \\
\hline Webster & 211 & 383 & 610 & 601 & 511 & 539 & 601 \\
\hline Wetzel & 295 & 421 & 492 & WII & 381 & 391 & 416 \\
\hline Wirt & 89 & 114 & 107 & 100 & 94 & 100 & 101 \\
\hline Wood & 616 & 807 & 908 & 849 & 768 & 811 & 868 \\
\hline Wyaming & 252 & 423 & 633 & 566 & 639 & 730 & 848 \\
\hline TOTAL & 15,600 & 22,135 & 29,721 & 27,286 & 27,962 & 30,136 & 32,229 \\
\hline
\end{tabular}

Section III WELFARE
W. Va. Univ.

Agr. Exp. Sta.

Bul. Na. 464 
TABLE IC. INDEX OF THE TOTAL AMOUNTS (ADJUSTED BY THE WHOLESALE COMMODITY INDEX) FOR THE WELFARE PROGRAMS AS ALLOCATED, IN THE ANNUAL REPORTS, TO THE COUNTIES BY THE STATE DEPARTMENT OF PUBLIC ASSISTANCE, $1950=100$

The data presented here are based on the preceding table,

Table 1B, Section III.

Section III

WELFARE

W. Vo. Univ.

Agr. Exp. Sta.

Bul. Na. 464

Page 32

\begin{tabular}{|c|c|c|c|c|c|c|c|}
\hline COUNTY & $1939-40$ & $1949-50$ & $1954-55$ & $1955-56$ & $1957-58$ & $1958-59$ & $1959-60$ \\
\hline Barbour & 60 & 100 & 100 & 89 & 86 & 86 & 87 \\
\hline Berkeley & 92 & 100 & 110 & 95 & 102 & 116 & 137 \\
\hline Boooe & 48 & 100 & 231 & 186 & 202 & 210 & 215 \\
\hline Braxton & 34 & 100 & 98 & 89 & 87 & 90 & 92 \\
\hline Brooke & 132 & 100 & 105 & 88 & 95 & 108 & 117 \\
\hline Cabell & 114 & 100 & 104 & 94 & 115 & 128 & 140 \\
\hline Calhoun & 40 & 100 & 59 & 58 & 66 & 74 & 80 \\
\hline Clay & 44 & 100 & 228 & 111 & 116 & 124 & 124 \\
\hline Doddridge & 58 & 100 & 87 & 67 & 71 & 77 & 77 \\
\hline Fayecte & 100 & 100 & 204 & 194 & 212 & 230 & 249 \\
\hline Gilmer & 53 & 100 & 123 & 111 & 106 & 111 & 112 \\
\hline Grant & 103 & 100 & 135 & 115 & 122 & 122 & 137 \\
\hline Greenbrier & 36 & 100 & 102 & 87 & 75 & 79 & 82 \\
\hline Hampshire & 89 & 100 & 118 & 100 & 102 & 110 & 122 \\
\hline Haocock & 116 & 100 & 115 & 105 & 118 & 126 & 134 \\
\hline Hardy & 86 & 100 & 111 & 99 & 107 & 117 & 129 \\
\hline Harrison & 134 & 100 & 97 & 90 & 84 & 91 & 91 \\
\hline Jackson & 68 & 100 & 117 & 103 & 104 & 114 & 114 \\
\hline Jefferson & 138 & 100 & 106 & 104 & 121 & 138 & 151 \\
\hline Kanawha & 84 & 100 & 197 & 195 & 189 & 188 & 183 \\
\hline Lewis & 40 & 100 & 124 & 115 & 120 & 128 & 140 \\
\hline Lincolo & 50 & 100 & 133 & 119 & 134 & 146 & 157 \\
\hline Logao & 61 & 100 & 248 & 225 & 246 & 278 & 294 \\
\hline McDowell & 71 & 100 & 201 & 191 & 208 & 248 & 272 \\
\hline Marion & 86 & 100 & 100 & 87 & 93 & 102 & 104 \\
\hline Marshall & 86 & 100 & 24 & 87 & 82 & 86 & 95 \\
\hline Masoo & 87 & 100 & 120 & 108 & 116 & 124 & 126 \\
\hline Mercer & $6_{4}$ & 100 & 160 & 160 & 183 & 211 & 249 \\
\hline Mineral & 175 & 100 & 134 & 127 & 124 & 131 & 137 \\
\hline Mingo & 41 & 100 & 133 & 116 & 126 & 142 & 155 \\
\hline Monongalia & 102 & 100 & 113 & 98 & 105 & 108 & 108 \\
\hline Monroe & 55 & 100 & 125 & 107 & 114 & 117 & 132 \\
\hline Morgan & 120 & 100 & 95 & 82 & 84 & 102 & 119 \\
\hline Nicholas & 6 & 100 & 145 & 129 & 131 & 138 & 147 \\
\hline Ohio & 100 & 100 & 110 & 91 & 93 & 100 & 109 \\
\hline Pendletoo & 56 & 100 & 139 & 221 & 122 & 127 & 134 \\
\hline Pleasants & 87 & 100 & 107 & 95 & 94 & 99 & 103 \\
\hline Pocahootas & 56 & 100 & 96 & 93 & 91 & 94 & 100 \\
\hline Preston & 82 & 100 & 93 & 77 & 70 & 73 & 72 \\
\hline Putoam & 67 & 100 & 120 & 107 & 109 & 116 & 114 \\
\hline Raleigh & 70 & $100^{-}$ & 172 & 155 & 140 & 148 & 162 \\
\hline Randolph & 81 & 100 & 114 & 113 & 108 & 112 & 129 \\
\hline Ritchie & 80 & 100 & 80 & 75 & 79 & 85 & 89 \\
\hline Roaoe & 120 & 100 & 166 & 165 & 189 & 217 & 253 \\
\hline Summers & 39 & 100 & 162 & 142 & 141 & 155 & 171 \\
\hline Taylor & 80 & 100 & 84 & 75 & 74 & 75 & 74 \\
\hline Tucker & 57 & 100 & 97 & 93 & 80 & 82 & 91 \\
\hline Tyler & 57 & 100 & 128 & $11_{4}$ & 112 & 117 & 122 \\
\hline Upshur & 77 & 100 & 118 & 116 & $12 \overline{9}$ & 143 & 159 \\
\hline Wayoe & 38 & 100 & 115 & 107 & 113 & 122 & 132 \\
\hline Webscer & 55 & 100 & 159 & 157 & 133 & 141 & 157 \\
\hline Wetzel & 70 & 100 & 117 & 98 & 90 & 93 & 99 \\
\hline Wirt & 78 & 100 & 94 & $88^{-}$ & 82 & 88 & 89 \\
\hline Wood & 76 & 100 & 113 & 105 & 95 & 100 & 108 \\
\hline Wyoming & 60 & 100 & 150 & 134 & 151 & 173 & 200 \\
\hline TOTAL & 70 & 100 & 134 & 123 & 126 & 136 & 11,6 \\
\hline
\end{tabular}




\section{TABLE 1D. A COMPARISON BETWEEN THE TOTAL EXPENDITURES FOR WELFARE IN THE COUNTIES OF WEST VIRGINIA AND THE TOTAL PERSONAL INCOME OF THE COUNTIES OF WEST VIRGINIA - TOTAL EXPENDITURES FOR WELFARE IS REPRESENTED AS PERCENTAGES OF THE TOTAL PERSONAL INCOME}

The amounts considered in the data presented below contain all transfer payments of the federal, state, and local governments and a dministrative and casework programs allocated to the counties.

The amounts contain only those state funds allocated to specific county units. Some welfare funds are not allocated, as a budget procedure, to the counties but are used for the benefit of people in the counties. No values have been assigned to commodities made available by the Federal government and distributed through State and local facilities, nor are amounts expended by private welfare groups included. In order to secure a comprehensive view of welfare programs in the counties, these additional sources should be considered.

\begin{tabular}{|c|c|c|c|c|c|c|c|}
\hline COUNTY & 1940 & 1950 & 1955 & 1957 & 1958 & 1959 & 1960 \\
\hline Barbour & 2.28 & 2.34 & 2.38 & 2.03 & 1.96 & 1.94 & 1.89 \\
\hline Berkeley & .66 & .44 & .45 & .37 & .39 & .42 & .48 \\
\hline Boone & .75 & .91 & 1.90 & 1.55 & 1.78 & 1.87 & 1.88 \\
\hline Braxton & 2.32 & 4.24 & 3.78 & 3.06 & 2.93 & 3.15 & 3.50 \\
\hline Brooke & .75 & .12 & .40 & .33 & .37 & .012 & .43 \\
\hline Cabell & .83 & .44 & .133 & .39 &. $\mathrm{Lth}_{4}$ & .47 & .50 \\
\hline Calhoun & 2.24 & 4.43 & 2.69 & 2.32 & 2.64 & 2.89 & 3.02 \\
\hline Clay & 2.16 & 3.12 & 3.87 & 3.39 & 3.71 & 4.13 & 4.19 \\
\hline Doddridge & 2.15 & 2.54 & 2.55 & 1.99 & 1.88 & 2.07 & 1.88 \\
\hline Fayette & .84 & .61 & 1.35 & 1.34 & 1.49 & 1.59 & 1.68 \\
\hline Gilmer & 2.28 & 2.93 & 3.90 & 3.14 & 3.05 & 2.93 & 2.80 \\
\hline Grant & 2. . & .93 & 1.18 & .92 & .97 & .93 & 1.05 \\
\hline Greenbrier & .99 & 1.76 & 1.75 & 1.23 & 1.20 & 1.26 & 1.28 \\
\hline Hampshire & 2.22 & 1.38 & 1.53 & 1.24 & 1.32 & 1.34 & 1.43 \\
\hline Haucock & .26 & .23 & .24 & .20 & .22 & .21 & .21 \\
\hline Hardy & 1.88 & 1.01 & 1.13 & .99 & 1.08 & 1.11 & 1.19 \\
\hline Harrisna & .79 & .34 & .33 & .27 & .26 & .29 & .28 \\
\hline Jacksoo & 2.13 & 1.65 & 1.63 & .58 & .87 & .81 & .77 \\
\hline Jeffersoa & 1.59 & .68 & .63 & .65 & .69 & .65 & .56 \\
\hline Kanawha & .70 & .52 & .92 & .84 & .80 & .76 & .72 \\
\hline Lewis & 1.23 & 2.10 & 2.61 & 2.51 & 2.50 & 2.59 & 2.78 \\
\hline Liacoln & 3.24 & 3.91 & 4.49 & 3.81 & 4.29 & 4.71 & 4.85 \\
\hline Logan & .63 & .65 & 1.61 & 1.33 & 1.55 & 1.82 & 1.92 \\
\hline MeDnwell & .56 & .72 & 1.63 & 1.58 & 1.87 & 2.38 & 2.69 \\
\hline Marion & .70 & .55 & .55 & .47 & .46 & .51 & .50 \\
\hline Marshall & 1.22 & .90 & .71 & .60 & .56 & .61 & .64 \\
\hline Mason & 2.21 & 1.02 & 1.02 & .85 & .91 & .95 & .91 \\
\hline Mercer & .79 & .86 & 1.33 & 1.31 & 1.45 & 1.76 & 2.04 \\
\hline Mineral & 1.68 & 1.19 & 1,48 & 1.21 & 1.13 & .94 & .91 \\
\hline Miago & 1.33 & 1.77 & 2.22 & 2.13 & 2.54 & 3.01 & 3.34 \\
\hline Mooongalia & .85 & .54 & .58 & .48 & .52 & .52 & .52 \\
\hline Monsoe & 2.20 & 2.09 & 2.68 & 2.20 & 2.14 & 2.36 & 2.59 \\
\hline Morgao & 2.01 & 1.12 & .95 & .75 & .81 & .91 & 1.08 \\
\hline Nicholas & 2.26 & 1.56 & 2.09 & 1.69 & 1.89 & 1.97 & 2.01 \\
\hline Ohio & .65 & .48 & .49 & .37 & .39 & $.1,1$ & .42 \\
\hline Pendleton & 1.59 & 2.05 & 2.43 & 1.90 & 1.93 & 1.74 & 1.87 \\
\hline Pleasants & 1.98 & 1.70 & 1.51 & 1.21 & 1.12 & 1.18 & 1.19 \\
\hline Pocahootas & 1.47 & 2.05 & 1.93 & 1.57 & 1.77 & 1.69 & 1.80 \\
\hline Preston & 2.18 & 1.42 & 1.58 & 1.08 & 1.13 & 1.16 & 1.12 \\
\hline Putnam & 1.75 & 1.82 & 1.73 & 1.30 & 1.31 & 1.18 & 1.24 \\
\hline Raleigh & .67 & .77 & 1.40 & .98 & 1.01 & 1.13 & 1.21 \\
\hline Randolph & 2.17 & 1.86 & 2.10 & 1.84 & 1.81 & 1.80 & 1.97 \\
\hline Ritchie & 2.83 & 2.55 & 1.95 & 1.78 & 1.83 & 2.00 & 1.94 \\
\hline Roaoc & 1.95 & 1.11 & 1.69 & 1.63 & 1.70 & 1.92 & 2.08 \\
\hline Summers & 1.45 & 2.58 & 4.37 & 3.54 & 3.78 & 4.03 & 4.38 \\
\hline Taylor & 7.64 & 1,64 & 1.36 & 1,04 & 1.18 & 1.22 & 1.23 \\
\hline Tucker & 2.26 & 3,32 & 3.50 & 2.78 & 2.77 & 2.80 & 2.93 \\
\hline Tyler & 2.21 & 3.13 & 3.71 & 3.10 & 2.83 & 3.14 & 3.01 \\
\hline Upshur & 2.90 & 1.92 & 2.26 & 2.07 & 2.35 & 2.60 & 2.73 \\
\hline Wayae & 2.53 & 3.56 & 3.48 & 3.10 & 3.31 & 3.41 & 3.36 \\
\hline Webster & 2,08 & 2.19 & 4.12 & 3.38 & 3.46 & 3.70 & 4.09 \\
\hline Wetzel & 2.20 & 1.95 & 2.03 & 1.46 & 1.33 & 1.34 & 1.42 \\
\hline Wirt & 2.83 & 2.67 & 2.40 & 1.92 & 1.79 & 2.06 & 1.93 \\
\hline Wnod & 1.13 & .94 & .93 & .70 & .69 & .70 & .71 \\
\hline Wyoming & 1.17 & 1.28 & 1.72 & 1.43 & 1.68 & 1.96 & 2.20 \\
\hline TOTAL & 1.04 & .99 & 1.27 & 1.06 & 1.12 & 1.18 & 1.22 \\
\hline
\end{tabular}

Section III WELFARE

W. Va. Univ.

Agr. Exp. Sta.

Bul. Na. 464

Page 33 
TABLE 2A. THE TOTAL AMOUNTS (IN THOUSANDS OF DOLLARS) OF TRANSFER PAYMENTS OF ALL PUBLIC WELFARE PROGRAMS AS ALLOCATED, IN THE ANNUAL REPORTS, TO THE COUNTIES BY THE

STATE DEPARTMENT OF PUBLIC ASSISTANCE

The data presented here were taken from the Annual Report of the Department of Public Assistance, State of West Virginia. The total amounts consist of state and federal monies in such programs as Aid to the Blind, Aid for Dependent Children, Aid to Totally and Permanently Disabled, Public Assistance, and the County's General Relief Program. These amounts do not include any value for surplus commodities provided by the federal government to certified recipients.

Section III

WELFARE

W. Va. Univ.

Agr. Exp. Sta.

Bul. No. 464

Page 34

\begin{tabular}{|c|c|c|c|c|c|c|}
\hline COUNTY & $1939-40$ & $1949-50$ & $1954-55$ & $1957-58$ & $1958-59$ & $1959-60$ \\
\hline Barbour & 118 & 434 & 487 & 450 & 455 & 454 \\
\hline Berkeley & 70 & 177 & 218 & 220 & 252 & 292 \\
\hline Boone & 58 & 277 & 668 & 684 & 718 & 730 \\
\hline Braxton & 93 & 606 & 663 & 630 & 656 & 674 \\
\hline Brooke & 85 & 140 & 163 & 160 & 182 & 193 \\
\hline Cabell & 310 & 597 & 690 & 832 & 929 & 1,008 \\
\hline Calhoun & 50 & 288 & 189 & 228 & 256 & 276 \\
\hline Clay & 77 & 380 & 542 & 533 & 570 & 566 \\
\hline Doddridge & 50 & 191 & 188 & 161 & 177 & 175 \\
\hline Fayette & 24 & 552 & 1,277 & 1,433 & 1,566 & 2,673 \\
\hline Gilmer & 52 & 220 & 307 & 282 & 297 & 298 \\
\hline Grant & 46 & 97 & 151 & 146 & 146 & 164 \\
\hline Greenbrier & 100 & 649 & 741 & 580 & 618 & 639 \\
\hline Hampshire & 65 & 167 & 223 & 204 & 224 & 246 \\
\hline Haacock & 59 & 114 & 151 & 168 & 180 & 190 \\
\hline Hardy & 52 & 131 & 165 & 173 & 190 & 205 \\
\hline Harrison & 216 & 365 & 395 & 370 & 403 & 396 \\
\hline Jacksoa & 74 & 240 & 317 & 303 & 332 & 331 \\
\hline Jefferson & 75 & 118 & 143 & 175 & 201 & 218 \\
\hline Kanawha & 584 & 1,526 & 3,392 & 3,506 & 3,485 & 3,372 \\
\hline Lewis & 66 & 375 & 523 & 54 & 584 & 638 \\
\hline Lincola & 115 & 534 & 797 & 863 & 948 & 1,024 \\
\hline Logaa & 153 & 563 & 1,573 & 1,681 & 1,904 & 2,009 \\
\hline McDowell & 240 & 740 & 1,675 & 1,860 & 2,241 & 2,444 \\
\hline Marion & 181 & 461 & 515 & 514 & 572 & 574 \\
\hline Marshall & 171 & 430 & 453 & 427 & 451 & 491 \\
\hline Mason & 107 & 267 & 361 & 374 & 401 & 408 \\
\hline Mercer & 194 & 681 & 1,231 & 1,513 & 1,758 & 2,060 \\
\hline Mineral & 24 & 182 & 274 & 275 & 289 & 299 \\
\hline Miago & 151 & 826 & 1,231 & 1,259 & 1,425 & 1.552 \\
\hline Mooongalia & 164 & 365 & 465 & 465 & 479 & 471 \\
\hline Monroe & 59 & 247 & 347 & 342 & 352 & 391 \\
\hline Morgan & 55 & 103 & 110 & 106 & 128 & 150 \\
\hline Nicholas & 113 & 397 & 650 & 629 & 666 & 709 \\
\hline Ohio & 226 & 513 & 630 & 576 & 626 & 672 \\
\hline PendIeton & 35 & 140 & 221 & 205 & 215 & 227 \\
\hline Pleasants & 39 & 102 & 122 & 116 & 121 & 126 \\
\hline Pocaboatas & 55 & 223 & 243 & 245 & 255 & 273 \\
\hline Preston & 152 & 409 & 425 & 341 & 359 & 356 \\
\hline Putnam & 96 & 309 & 416 & 407 & 434 & 426 \\
\hline Raleigh & 232 & 731 & 1,423 & 1,238 & 1,314 & 1,433 \\
\hline Randolph & 171 & 459 & 591 & 604 & 627 & 722 \\
\hline Ritchie & 98 & 266 & 237 & 249 & 273 & 284 \\
\hline Roane & 80 & 149 & 282 & 346 & 401 & 462 \\
\hline Summers & 78 & 447 & 802 & 749 & 833 & 914 \\
\hline Taylor & 92 & 255 & 237 & 222 & 226 & 224 \\
\hline Tucker & 76 & 293 & 321 & 282 & 292 & 321 \\
\hline Tylet & 64 & 249 & 355 & 333 & 352 & 363 \\
\hline Upsbur & 109 & 300 & 401 & 472 & 526 & 584 \\
\hline Wayoe & 154 & 905 & 1,176 & 1,243 & 1,349 & 1,450 \\
\hline Webstex & 94 & 369 & 664 & 598 & 632 & 702 \\
\hline Wetzel & 127 & 405 & 533 & 447 & 455 & 483 \\
\hline Wirt & 38 & 109 & 215 & 108 & 114 & 117 \\
\hline Wood & 269 & 779 & 979 & 891 & 946 & 1,012 \\
\hline Wyomin $B$ & 111 & 409 & 685 & 745 & 858 & 990 \\
\hline TOTAL & 6.736 & 21,255 & 32,133 & 32,501 & 35,243 & 37,462 \\
\hline
\end{tabular}


TABLE 2B. THE TOTAL AMOUNTS (IN THOUSANDS OF DOLLARS ADJUSTED BY THE WHOLESALE COMMODITY INDEX) OF TRANSFER PAYMENTS OF

ALL PUBLIC WELFARE PROGRAMS AS ALLOCATED, IN THE ANNUAL REPORTS, TO THE COUNTIES BY THE STATE DEPARTMENT OF PUBLIC ASSISTANCE

Data presented in this table are based on those in the preced-

ing table, Table 2A, Section III.

\begin{tabular}{|c|c|c|c|c|c|c|c|}
\hline COUNTY & 1940 & 1950 & 1955 & 1957 & 1958 & 1959 & $1959-60$ \\
\hline Batbour & 231 & 421 & 440 & 401 & 378 & 381 & 380 \\
\hline Berkeley & 137 & 172 & 197 & 165 & 185 & 211 & 245 \\
\hline Boone & 114 & 269 & 603 & 561 & 574 & 601 & 611 \\
\hline Braxton & 182 & 588 & 599 & 554 & 529 & 549 & 564 \\
\hline Brooke & 166 & 136 & 147 & 126 & 134 & 152 & 162 \\
\hline Cabell & 607 & 579 & 623 & 640 & 698 & 778 & 844 \\
\hline Calhoun & 98 & 279 & 171 & 172 & 191 & 214 & 231 \\
\hline Clay & 151 & 369 & 490 & 439 & 447 & 477 & 474 \\
\hline Doddridge & 98 & 185 & 170 & 136 & 135 & 148 & 147 \\
\hline Fayette & 477 & 535 & 1,154 & 1,174 & 1,202 & 1,312 & 1,401 \\
\hline$\overline{\text { Gilmer }}$ & 102 & 213 & 277 & 241 & 237 & 249 & 250 \\
\hline Graot & 90 & 94 & 136 & 118 & 122 & 122 & 137 \\
\hline Green brier & 196 & 629 & 669 & 528 & 487 & 518 & 535 \\
\hline Hampshire & 127 & 162 & 201 & 170 & 171 & 188 & 206 \\
\hline Haocock & 115 & 111 & 136 & 128 & 141 & 151 & 159 \\
\hline Hardy & 102 & 127 & 149 & 140 & 145 & 159 & 172 \\
\hline Harrison & 423 & 354 & 357 & 329 & 310 & 338 & 332 \\
\hline Jackson & 145 & 233 & 286 & 269 & 254 & 278 & 277.2 \\
\hline Jeffersoo & 147 & 114 & 129 & 137 & 147 & 168 & 182.6 \\
\hline Kanawha & 1,143 & 1,480 & 3,064 & 3,157 & 2,941 & 2,919 & $2,824.1$ \\
\hline Lewis & 129 & 364 & 472 & 453 & 456 & 489 & 534.3 \\
\hline Liocoln & 225 & 518 & 720 & 689 & 724 & 794 & 857.6 \\
\hline Logan & 299 & 546 & 1,421 & 1,389 & 1,410 & 1,595 & $1,682.6$ \\
\hline McDowell & 470 & 718 & 1.513 & 1,504 & 1,560 & 1,877 & $2,046.9$ \\
\hline Marion & 354 & 447 & 465 & 446 & 431 & 479 & 480.7 \\
\hline Marsball & 335 & 417 & 409 & 370 & 358 & 378 & 411.2 \\
\hline Masoo & 209 & 259 & 326 & 290 & 314 & 336 & 341.7 \\
\hline Metcer & 380 & 661 & 1,112 & 1,219 & 1,269 & 1,472 & $1,725,3$ \\
\hline Mineral & 184 & 177 & 248 & 236 & 231 & 242 & 250.4 \\
\hline Miogo & 295 & 801 & 1,112 & 1,001 & 1,056 & 1,193 & 1.299 .8 \\
\hline Moooogalia & 321 & 354 & 420 & 385 & 390 & 401 & 394.5 \\
\hline Monroe & 115 & 240 & 313 & 284 & 287 & 295 & 327.5 \\
\hline Morgao & 108 & 100 & 99 & 86 & 89 & 107 & 125.6 \\
\hline Nicholas & 221 & 385 & 587 & 537 & 528 & 558 & 593.8 \\
\hline Obia & 442 & 498 & 569 & 478 & 483 & 524 & 562.8 \\
\hline Pendletoa & 68 & 136 & 200 & 169 & 172 & 180 & 190.1 \\
\hline Pleasaots & 76 & 99 & 110 & 105 & 97 & 101 & 105.5 \\
\hline Pocahootas & 108 & 216 & 220 & 206 & 206 & 214 & 228.6 \\
\hline Prestoa & 297 & 397 & 384 & 301 & 286 & 301 & 298.2 \\
\hline Putaam & 188 & 300 & 376 & 357 & 341 & 363 & 356.8 \\
\hline Raleigh & 452 & 709 & 1,285 & 1,111 & 1,039 & 1,100 & $1,200,2$ \\
\hline Randolph & 335 & 445 & 534 & 520 & 507 & 525 & 604.7 \\
\hline Ritchie & 192 & 258 & 214 & 210 & 209 & 229 & 237.9 \\
\hline Roade & 157 & 145 & 255 & 276 & 290 & 336 & 386.9 \\
\hline Summers & 153 & 428 & 724 & 631 & 628 & 698 & 765.5 \\
\hline Taylor & 180 & 247 & 214 & 180 & 186 & 189 & 187.6 \\
\hline Tucker & 149 & 284 & 290 & 244 & 237 & 245 & 268.8 \\
\hline Tyler & 125 & 242 & 321 & 285 & 279 & 295 & 304.0 \\
\hline Upshur & 213 & 291 & 362 & 372 & 396 & 441 & 489.1 \\
\hline Wayae & 301 & 878 & 1,062 & 1,026 & 1,043 & 1,130 & $1,214.4$ \\
\hline Webster & 184 & 358 & 600 & 534 & 502 & 529 & 587.9 \\
\hline Wetzel & 249 & 393 & 481 & 395 & 370 & 381 & 404.5 \\
\hline$\overline{\text { Wirt }}$ & 74 & 105 & 104 & 98 & 91 & 95 & 98.0 \\
\hline Wood & 526 & 756 & 884 & 778 & 747 & 792 & 847.6 \\
\hline Wyoming & 217 & 397 & 619 & 608 & 625 & 719 & 829.1 \\
\hline TOTAL & 13,182 & 20,616 & 29,027 & 27,360 & 27,266 & 29,517 & $31,375.2$ \\
\hline
\end{tabular}

Section III

WELFARE

W. Vo. Univ.

Agr. Exp. Sto.

Bul. No. 464 
TABLE 2C. INDEX OF THE TOTAL AMOUNTS (AD JUSTED BY THE WHOLESALE COMMODITY INDEX) OF TRANSFER PAYMENTS OF ALL PUBLIC WELFARE PROGRAMS AS ALLOCATED, IN THE ANNUAL REPORTS, TO THE COUNTIES BY THE STATE DEPARTMENT OF PUBLIC ASSISTANCE, $1950=100$

Data presented here are based on those presented in the preceding table, Table $2 \mathrm{~B}$, Section III.

Section III

WELFARE
W. Vo. Univ.

Agr. Exp. Sto. Bul. No. 464

Page 36

\begin{tabular}{|c|c|c|c|c|c|c|c|}
\hline COUNTY & 1940 & 1950 & 1955 & 1957 & 1958 & 1959 & 1960 \\
\hline Barbour & 54.9 & 100.0 & 104.5 & 95.2 & 89.8 & 90.5 & 90.3 \\
\hline Berkeley & 79.7 & 100.0 & 114.5 & 95.9 & 107.6 & 122.7 & 142.2 \\
\hline Boooe & 42.4 & 100.0 & 224.2 & 208.6 & 273.4 & 223.4 & 227.3 \\
\hline Braztoo & 37.0 & 100.0 & 101.9 & 91.2 & 90,0 & 93.4 & 96.0 \\
\hline Brooke & 122.1 & 100.0 & 108.1 & 92.6 & 98.5 & 111.8 & 118.8 \\
\hline Cabell & 104.8 & 100.0 & 107.6 & 110.5 & 120.6 & 134.11 & 145.8 \\
\hline Calhoun & 35.1 & 100.0 & 61.3 & 61.6 & 68.5 & 76.7 & 82.9 \\
\hline Clay & 40.9 & 100.0 & 132.8 & 119.0 & 121.7 & 729.3 & 128.5 \\
\hline Doddridge & 53.0 & 100.0 & 91.2 & 73.5 & 73.0 & 80.0 & 79.2 \\
\hline Fayezte & 89.2 & 100.0 & 215.7 & 219.4 & 224.7 & $24,5.2$ & 261.9 \\
\hline Gilmer & 47.9 & 100.0 & 130.0 & 173.1 & 111.3 & 716.9 & 1722 \\
\hline Grant & 95.7 & 100.0 & $71,4.7$ & 125.5 & 129.8 & 129.8 & 11.6 .2 \\
\hline Greenbrier & 31.2 & 100.0 & 106.4 & 83.9 & 77.14 & 82.4 & 85.1 \\
\hline Hampshire & 78.4 & 100.0 & 124.1 & 104.9 & 105.6 & 116.0 & 127.2 \\
\hline Haacock & 103.6 & 100.0 & 122.5 & 715.3 & 127.0 & 136.0 & 143.3 \\
\hline Hardy & 80.3 & 100.0 & 117.3 & 110.2 & 111.2 & 125.2 & 135.2 \\
\hline Hafrisoo & 119.5 & 100.0 & 100.8 & 92.9 & 87.6 & 95.5 & 93.7 \\
\hline Jackson & 62.2 & 100.0 & 122.7 & 115.4 & 109.0 & 119.3 & 119.0 \\
\hline Jefferson & 128.9 & 100.0 & 113.2 & 120.2 & 128.9 & 147.4 & 160.2 \\
\hline Kana wha & 77.2 & 100.0 & 207.0 & 213.3 & 198.7 & 197.2 & 190.8 \\
\hline Lewis & 35.4 & 100.0 & 129.7 & 124.4 & 125.3 & 134.3 & 11.6 .8 \\
\hline Lincoln & 43.4 & 100.0 & 139.0 & 133.0 & 139.8 & 153.3 & 165.6 \\
\hline Logan & 54.8 & 100.0 & 260.3 & 254.4 & 258.2 & 292.1 & 308.2 \\
\hline McDowell & 65.5 & 100.0 & 210.7 & 209.5 & 217.3 & 261.4 & 285.1 \\
\hline Marioo & 79.2 & 100.0 & 104.0 & 99.8 & 96.4 & 107.2 & 107.5 \\
\hline Marshall & 80.3 & 100.0 & 98.1 & 88.7 & 85.9 & 90.6 & 98.6 \\
\hline Mason & 80.7 & 100.0 & 125.9 & 112.0 & 121.2 & 129.7 & 131.9 \\
\hline Mercer & 57.5 & 100.0 & 168.2 & 184.4 & 192.0 & 222.7 & 261.0 \\
\hline Mineral & 104.0 & 100.0 & 140.1 & 133.3 & 130.5 & 136.7 & 111.5 \\
\hline Mingo & 36,8 & 100.0 & 138.8 & 125.0 & 131.8 & 148.9 & 162.3 \\
\hline Moooogalia & 90.7 & 100.0 & 113.6 & 108.8 & 110.2 & 113.3 & 111.4 \\
\hline Monroe & 47.9 & 100.0 & 130.4 & 118.3 & 110.6 & 122.9 & 136.5 \\
\hline Morgaa & 108.0 & 100.0 & 99.0 & 86.0 & 89.0 & 107.0 & 125.6 \\
\hline Nicholas & 57.4 & 100.0 & 152.5 & 139.5 & 137.1 & 144.2 & 154.2 \\
\hline Obio & 88.8 & 100.0 & 114.3 & 96.0 & 97.0 & 105.2 & 113.0 \\
\hline Pendletnn & 50.0 & 100.0 & 147.1 & 124.3 & 126.5 & 132.4 & 139.8 \\
\hline Pleasants & 76.8 & 100.0 & 111.1 & 106.1 & 98.0 & 102.0 & 106.6 \\
\hline Pocahootas & 50.0 & 100.0 & 101.9 & 95.4 & 95.4 & 99.1 & 105.8 \\
\hline Preston & 74.8 & 100,0 & 96.7 & 75.8 & 72.0 & 75.8 & 75.1 \\
\hline Pntnam & 62.7 & 100.0 & 125.3 & 119.0 & 113.7 & 121.0 & 118.9 \\
\hline Raleigh & 63.8 & 100.0 & 181.2 & 156.7 & 146.5 & 155.1 & 169.3 \\
\hline Raodolph & 75.3 & 100.0 & 120.0 & 116.9 & 113.9 & 118.0 & 135.9 \\
\hline Ritchie & 74.4 & 100.0 & 82.9 & 81.4 & 81,0 & 88.8 & 92.2 \\
\hline Roane & 108.3 & 100.0 & 175.9 & 190.3 & 200.0 & 231.7 & 266.8 \\
\hline Summers & 35.7 & 100.0 & 169.2 & 247.4 & 146.7 & 163.1 & 178.9 \\
\hline Taylor & 72.9 & 100.0 & 86.6 & 72.9 & 75.3 & 76.5 & 76.0 \\
\hline Tucker & 52.5 & 100,0 & 102.1 & 85.9 & 83.1 & 86.3 & 94.6 \\
\hline Tyler & 51.7 & 100.0 & 132.6 & 117.8 & 115.3 & 121.9 & 125.6 \\
\hline Upshur & 73.2 & 100.0 & 124.4 & 127.8 & 136.1 & 151.5 & 168.1 \\
\hline Wayoe & 34.3 & 100.0 & 121.0 & 116.9 & 178.8 & 128.7 & 138.3 \\
\hline Webster & 51.4 & 100.0 & 167.6 & 149.2 & $1 / 40.2$ & $7 / 17.8$ & 164.2 \\
\hline Wetze! & 63.4 & 100,0 & 122.11 & 100.5 & 94.1 & 96.9 & 102.9 \\
\hline Wirt & 70.5 & 100.0 & 99.0 & 93.3 & 86.7 & 90.5 & 93,3 \\
\hline Tood & 69.6 & 100.0 & 116.9 & 102.9 & 28.8 & 104.8 & 112.1 \\
\hline Tyoming & 54.7 & 100.0 & 155.9 & 153,1 & 157.4 & 181.1 & 208.8 \\
\hline TOTAL & 63.9 & 100.0 & 140.8 & 132.7 & 132.3 & 143.2 & 151.7 \\
\hline
\end{tabular}


TABLE 3A. THE TOTAL AMOUNTS (IN THOUSANDS OF DOLLARS) OF

TRANSFER PAYMENTS THROUGH THE PROGRAM OF OLD AGE ASSISTANCE

TO RECIPIENTS IN THE COUNTIES OF WEST VIRGINIA

The information presented in this table is taken from the annual reports of the Department of Public Assistance, State of West Virginia.

\begin{tabular}{|c|c|c|c|c|c|c|c|}
\hline COUNTY & $39-40$ & $49-50$ & $54-55$ & $56-57$ & $57-58$ & $58-59$ & $59-60$ \\
\hline Barbour & 53 & 152 & 145 & 136 & 130 & 129 & 120 \\
\hline Berkeley & 32 & 79 & 88 & 76 & 74 & 73 & 67 \\
\hline Boone & 22 & 95 & 318 & 109 & 112 & 111 & 107 \\
\hline Braxton & 46 & 208 & 221 & 195 & 192 & 197 & 191 \\
\hline Brooke & 27 & 61 & 57 & 48 & 53 & 52 & $\frac{121}{50}$ \\
\hline Cabell & 125 & 271 & 287 & 268 & 275 & 280 & 272 \\
\hline Calhnun & 20 & 69 & 64 & 65 & 65 & 69 & 69 \\
\hline Clay & 32 & 100 & 129 & 112 & 115 & 112 & 101 \\
\hline Doddridge & 26 & 78 & 82 & 67 & 69 & 73 & 67 \\
\hline Fayette & 78 & 178 & 24,3 & 237 & $\left.2 l_{1}\right)_{1}$ & 251 & $2 / 15$ \\
\hline Gilmer & 26 & 70 & 79 & 77 & 72 & 69 & 64 \\
\hline Grant & 21 & 39 & 59 & 52 & 54 & 52 & 50 \\
\hline Greeohrier & 10 & 234 & 204 & 171 & 158 & 160 & 156 \\
\hline Hampshire & 35 & 84 & 92 & 93 & 93 & 96 & 94 \\
\hline Hancock & 22 & 47 & 47 & 48 & 53 & 55 & 57 \\
\hline Hardy & 29 & 63 & 73 & 69 & 72 & 72 & 69 \\
\hline Harrison & 77 & 182 & 174 & 164 & 160 & 162 & 156 \\
\hline Jacksan & 41 & 106 & 121 & 118 & 115 & 11/4. & 104 \\
\hline Jefferson & 38 & 46 & 52 & 1.6 & 1,7 & 48 & 48 \\
\hline Xanawha & 203 & 542 & 755 & $7 \sqrt{2}$ & 735 & 722 & 691 \\
\hline Lewis & 35 & 176 & 228 & 226 & 224 & 222 & 221 \\
\hline Lincnln & 43 & 164 & 178 & 180 & 177 & 182 & 173 \\
\hline Logan & 38 & 166 & 263 & 272 & 262 & 269 & 259 \\
\hline McDowell & 70 & 180 & 201 & 195 & 198 & 200 & 201 \\
\hline Marion & 60 & 207 & 190 & 173 & 163 & 160 & 152 \\
\hline Marshall & 71 & 166 & 157 & 155 & 151 & 119 & 11,5 \\
\hline Mason & 67 & 158 & 176 & 161 & 151 & 152 & 146 \\
\hline Mercer & 67 & 228 & 268 & 266 & 266 & 278 & 285 \\
\hline Mineral & 41 & 80 & 89 & 90 & 84 & 86 & 81 \\
\hline Miogo & 54 & 220 & 230 & 199 & 202 & 210. & 204 \\
\hline Mooongalia & 57 & 176 & 176 & 177 & 171 & 159 & 150 \\
\hline Monroe & 34 & 109 & 117 & 97 & 92 & 90 & 92 \\
\hline Morgao & 22 & 37 & 36 & 33 & 33 & 33 & 31 \\
\hline Nicholas & 10 & 127 & 144 & 128 & 128 & 132 & 127 \\
\hline Ohio & 73 & 207 & 207 & 175 & 164 & 157 & 155 \\
\hline Pendleton & 16 & 16 & 56 & 50 & 52 & 53 & 51 \\
\hline Pleasants & 19 & 52 & 52 & Lil & Lil & 13 & $\frac{21}{11}$ \\
\hline Pocahontas & 27 & 74 & 75 & 74 & 68 & 65 & 63 \\
\hline Preston & 72 & 179 & 153 & 122 & 120 & 120 & 107 \\
\hline Putnam & 50 & 136 & 136 & 132 & 130 & 125 & 712 \\
\hline Raleigh & 60 & 205 & $2 \mathrm{l}]$ & 210 & 206 & 206 & 209 \\
\hline Randolph & 86 & 179 & 205 & 198 & 187 & 191 & 190 \\
\hline Ritchie & 52 & 126 & 118 & 114 & 118 & 125 & 117 \\
\hline Roane & 33 & 65 & 100 & 100 & 100 & 102 & 98 \\
\hline Summers & 30 & 127 & 190 & 170 & 168 & 182 & 179 \\
\hline Taylor & 47 & 125 & 96 & 96 & 92 & 98 & 93 \\
\hline Tucker & 36 & 122 & 108 & 100 & 98 & 102 & 95 \\
\hline Tyler & 3) & 741 & 756 & 734 & 128 & 130 & 121 \\
\hline Upshur & 55 & 116 & 1) & $1 \sqrt{11}$ & $1 / 2$ & 71.7 & 47 \\
\hline Wayoe & 58 & 290 & 281 & 269 & 264 & 272 & 270 \\
\hline Webster & 45 & 117 & 144 & 132 & 126 & 128 & 222 \\
\hline Wetzel & 56 & 132 & 162 & 144 & 115 & 145 & 135 \\
\hline Wirt & 18 & 50 & 54 & 17 & 1,6 & 19 & 17 \\
\hline Wood & 13 & 342 & 400 & 369 & 364 & 349 & 319 \\
\hline Wyoming & 37 & 120 & 120 & 108 & 111 & 176 & 122 \\
\hline TOTAL & 2603 & 7843 & 8747 & 8179 & 8073 & 8121 & 7832 \\
\hline
\end{tabular}

Section III

WELFARE

W. Va. Univ.

Agr. Exp. Sto.

Bul. No. 464 
TABLE 3B. THE TOTAL AMOUNTS (IN THOUSANDS OF DOLLARS ADJUSTED

BY THE WHOLESALE COMMODITY INDEX) OF TRANSFER PAYMENTS

THROUGH THE PROGRAM OF OLD AGE ASSISTANCE TO RECIPIENTS

IN THE COUNTIES OF WEST VIRG INIA

Data presented here are based on those in the preceding table,

Table 3A, Section III.

Section III

WELFARE

W. Va. Univ.

Agr. Exp. Sta.

Bul. Na. 464

Page 38

\begin{tabular}{|c|c|c|c|c|c|c|c|}
\hline COUNTY & 1940 & 1950 & 1955 & 1957 & 1958 & 1959 & 1960 \\
\hline Barbour & $1 \mathrm{OL}_{4}$ & 1147 & 131 & 176 & 109 & 108 & 100 \\
\hline Berkeley & 63 & 77 & 79 & 65 & 62 & 67 & 56 \\
\hline Boone & 43 & 92 & 107 & 93 & 94 & 93 & 90 \\
\hline Braxton & 90 & 202 & 200 & 166 & 767 & 165 & 160 \\
\hline Brooke & 53 & 59 & 57 & 1,7 & 14 & 14.4 & 112 \\
\hline Cabell & 245 & 263 & 259 & 228 & 231 & 234 & 228 \\
\hline Calhoun & 39 & 67 & 58 & 55 & 55 & 58 & 58 \\
\hline Clay & 63 & 97 & 117 & 95 & 96 & 94 & 85 \\
\hline Doddridge & 51 & 76 & 74 & 57 & 58 & 61 & 56 \\
\hline Fayette & 153 & 173 & 220 & 202 & 205 & 210 & 205 \\
\hline Gilmer & 51 & 68 & 71 & 65 & 60 & 58 & 54 \\
\hline Grant & 41 & 38 & 53 & 44 & 45 & hil & 42 \\
\hline Green hrier & 78 & 227 & 184 & 145 & 133 & 134 & 131 \\
\hline Hampshire & 68 & 81 & 83 & 79 & 78 & 80 & 79 \\
\hline Haccock & 43 & 40 & 42 & 41 & 44 & 46 & 48 \\
\hline Hardy & 57 & 61 & 66 & 59 & 60 & 60 & 58 \\
\hline Harrisoo & 151 & 177 & 157 & 139 & 134 & 136 & 131 \\
\hline Jackson & 80 & 103 & 109 & 100 & 96 & 95 & 87 \\
\hline Jeffersoo & 74 & 45 & 47 & 39 & 39 & 40 & 10 \\
\hline Kanawha & 397 & 526 & 682 & 635 & 617 & 605 & 579 \\
\hline Lewis & 68 & 171 & 206 & 192 & 188 & 186 & 185 \\
\hline Lincola & 84 & 159 & 161 & 153 & $1 / 18$ & 152 & 11,5 \\
\hline Logad & 74 & 167 & 238 & 231 & 220 & 225 & 217 \\
\hline McDowell & 137 & 175 & 182 & 166 & 166 & 168 & 168 \\
\hline Marion & 117 & 201 & 172 & 147 & 137 & 13山 & 127 \\
\hline Marshall & 139 & 161 & 142 & 132 & 127 & 125 & 121 \\
\hline Masoo & 131 & 153 & 159 & 137 & 129 & 127 & 122 \\
\hline Mercer & 131 & 221 & 242 & 226 & 223 & 233 & 239 \\
\hline Mineral & 80 & 78 & 80 & 77 & 70 & 72 & 68 \\
\hline Mingo & 106 & 213 & 208 & 169 & 169 & 176 & 171 \\
\hline Monongal ia & 100 & 171 & 159 & 151 & 143 & 133 & 126 \\
\hline Mooroe & 67 & 106 & 106 & 82 & 77 & 75 & 77 \\
\hline Morgan & 13 & 36 & 33 & 28 & 28 & 28 & 26 \\
\hline Nicholas & 78 & 123 & 130 & 109 & 107 & 111 & 106 \\
\hline Ohio & 14,3 & 201 & 187 & 149 & 138 & 131 & 130 \\
\hline Peadleton & 31 & 45 & 51 & 43 & 44 & 44 & 43 \\
\hline Pleasants & 37 & 50 & 47 & 37 & 37 & 36 & 34 \\
\hline Pocahontas & 53 & 72 & 68 & 63 & 57 & 54 & 53 \\
\hline Preston & 141 & $17 \mathrm{~h}$ & 138 & 104. & 101 & 101 & 90 \\
\hline Putnam & 28 & 132 & 123 & 312 & 109 & 105 & 94 \\
\hline Raleigh & 117 & 199 & 218 & 179 & 173 & 173 & 175 \\
\hline Raodolph & 168 & $17 \mathrm{~L}$ & 185 & 768 & 157 & 162 & 159 \\
\hline Ritchie & 102 & 122 & 107 & 97 & 99 & 105 & 98 \\
\hline Roane & 65 & 63 & 90 & 85 & 84 & 85 & 82 \\
\hline Summers & 59 & 123 & 172 & 145 & 141 & 152 & 150 \\
\hline Taylor & 92 & 121 & 87 & 82 & 83 & 82 & 78 \\
\hline Tucker & 70 & 118 & 98 & 85 & 82 & 85 & 80 \\
\hline Tyler & 67 & 137 & 141 & 124 & 107 & 109 & 101 \\
\hline Upahar & $10^{8}$ & 113 & 130 & 120 & 119 & 118 & 118 \\
\hline Wayoe & IIL & 281 & 254 & 229 & 221 & 228 & 226 \\
\hline Webster & 88 & 113 & 130 & 112 & 106 & 107 & 102 \\
\hline Wetzel & 110 & 128 & 116 & 122 & 122 & 121 & 173 \\
\hline Wirt & 35 & 48 & 119 & 40 & 39 & 41 & 39 \\
\hline Wood & 25 & 332 & 361 & 314 & 305 & 292 & 267 \\
\hline Wyoming & 72 & 116 & $10 \mathrm{~B}$ & 92 & 93 & 97 & 102 \\
\hline TOTAL & 5094 & 7607 & 7896 & 6955 & 6773 & $68 n 2$ & 6559 \\
\hline
\end{tabular}


This index is based on the data presented in the preceding table, Table 3B, Section III.

\begin{tabular}{|c|c|c|c|c|c|c|c|}
\hline COUNTY & 1940 & 1950 & 1955 & 1957 & 1958 & 1959 & 1960 \\
\hline Barbour & 70.7 & 100.0 & 89.1 & 78.9 & 74.1 & 73.5 & 68.0 \\
\hline Berkeley & 81.8 & 100,0 & 102.6 & 84.4 & 80.5 & 79.2 & 72.7 \\
\hline Boone & 46.7 & 100.0 & 116.3 & 101.1 & 102.2 & 101.1 & 97.8 \\
\hline Braxton & 44.6 & 100.0 & 99.0 & 82.2 & 79.7 & 81.7 & 79.2 \\
\hline Brooke & 89.8 & 100.0 & 86.4 & 69.5 & 74.6 & 74.6 & 71.2 \\
\hline Cabell & 93.2 & 100.0 & 98.5 & 86.7 & 87.8 & 89.0 & 86.7 \\
\hline Calhoun & 58.2 & 100.0 & 86.6 & 82.1 & 82.1 & 86.6 & 86.6 \\
\hline Clay & 64.9 & 200.0 & 120.6 & 97.9 & 99.0 & 96.9 & 87.6 \\
\hline Doddridge & 67.1 & 100.0 & 97.4 & 75.0 & 76.3 & 80.3 & 73.7 \\
\hline Fayette & 88.4 & 100.0 & 127.2 & 116.8 & 118.5 & 121.4 & 118.5 \\
\hline Gilmer & 75.0 & 100.0 & 104.4 & 95.6 & 88,2 & 85.3 & 79.4 \\
\hline Grant & 107.9 & 100.0 & 139.5 & 115.8 & 118.4 & 115.8 & 110.5 \\
\hline Greenbrier & 34.4 & 100,0 & 81.1 & 63.8 & 58.6 & 59.0 & 57.7 \\
\hline Hampshire & 84.0 & 100.0 & 102.5 & .97 .5 & 96.3 & 98.8 & 97.5 \\
\hline Haocock & 107.5 & 100.0 & 105.0 & 102.5 & 110,0 & 115.0 & 120.0 \\
\hline Hardy & 93.4 & 100.0 & 108.2 & 26.7 & 98.4 & 98.4 & 95.1 \\
\hline Harrisoa & 85.3 & 100.0 & 88.7 & 78.5 & 75.7 & 76.8 & 7). 0 \\
\hline Jacksoa & 77.7 & 100.0 & 105.8 & 97.1 & 93.2 & 92.2 & 84.5 \\
\hline Jefferson & 164.4 & 100.0 & 104.4. & $86 . ?$ & 86.7 & 88.9 & 88.9 \\
\hline Kanawha & 75.5 & 100.0 & 129.7 & 120.7 & 117.3 & 115.0 & 110.1 \\
\hline Lewis & 39.8 & 100.0 & 120.5 & 112.3 & 109.9 & 108.8 & 108.2 \\
\hline Lincoln & 52.8 & 100.0 & 101.3 & 96.2 & 93.1 & 95.6 & 91.2 \\
\hline Logan & 46.0 & 100.0 & 147.8 & 143.5 & 136.6 & 139.8 & 129.9 \\
\hline McDowell & 78.3 & 100.0 & 104.0 & 94.9 & 94.9 & 96.0 & 96.0 \\
\hline Marion & 58.2 & 100.0 & 85.6 & 73.1 & 68.2 & 66.7 & 63.2 \\
\hline Marshall & 86.3 & 100.0 & 88.2 & 82.0 & 78.9 & 77.6 & 75.2 \\
\hline Mason & 85.6 & 100.0 & 103.9 & 89.5 & 84.3 & 83.0 & 79.7 \\
\hline Mercer & 59.3 & 100.0 & 109.5 & 102.3 & 100.9 & 105.4 & 108.1 \\
\hline Mineral & 102.6 & 100.0 & 102.6 & 98.7 & 89.7 & 92.3 & 87.2 \\
\hline Mingo & 49.8 & 100.0 & 97.7 & 79.3 & 79.3 & 82.6 & 80.3 \\
\hline Monoogalia & 58.5 & 100.0 & 93.0 & 88.3 & 83.6 & 77.8 & 73.7 \\
\hline Monroe & 63.2 & 100.0 & 100.0 & 77.4 & 72.6 & 70.8 & 72.6 \\
\hline Morgan & 119.4 & 100.0 & 91.7 & 77.8 & 77.8 & 77.8 & 72.2 \\
\hline Nicholas & 63.4. & 100.0 & 105.7 & 88.6 & 87.0 & 90.2 & 86.2 \\
\hline Ohio & 71.1 & 100.0 & 93.0 & 24.1 & 68.7 & 65.2 & 64.7 \\
\hline Pendleton & 68.9 & 100.0 & 113.3 & 95.6 & 97.8 & 97.8 & 95.6 \\
\hline Pleasants & 74.0 & 100.0 & 94.0 & 74.0 & 74.0 & 72.0 & 68.0 \\
\hline Pocahontas & 73.6 & 100.0 & 94.4 & 87.5 & 79.2 & 75.0 & 73.6 \\
\hline Prestoo & 81.0 & 100,0 & 79.3 & 59.8 & 58.0 & 58.0 & 51.7 \\
\hline Putnam & 74.2 & 100.0 & 93.2 & 84.8 & 82.6 & 79.5 & 71.2 \\
\hline Raleigh & 58.8 & 100,0 & 109.5 & 89.9 & 86.9 & 86.9 & 87.9 \\
\hline Randolph & 96.6 & 100.0 & 106.3 & 96.6 & 90.2 & 93.1 & 91.4 \\
\hline Ritchie & 83.6 & 100.0 & 87.7 & 79.5 & 81.1 & 86.1 & 80.3 \\
\hline Roane & 103.2 & 100.0 & 142.9 & 134.9 & 133.3 & 134.9 & 130.2 \\
\hline Summers & 48.0 & 100.0 & 139.8 & 117.9 & 114.6 & 123.6 & 122.0 \\
\hline Taylor & 76.0 & 100.0 & 71.2 & 67.8 & 68.6 & 67.8 & 64.5 \\
\hline Tucker & 59.3 & 100.0 & 83.0 & 72.0 & 69,5 & 72.0 & 67.8 \\
\hline Tyler & 4.8 .9 & 100.0 & 102.2 & 83.2 & 78.7 & 79.6 & 73.7 \\
\hline Upshur & 95.6 & 100.0 & 115.0 & 106.2 & 105.3 & 104.4 & 104.4 \\
\hline Wayne & 40.6 & 100.0 & 90.4 & 81.5 & 78.6 & 81.1 & 80.4 \\
\hline Wehster & 77.9 & 100.0 & 115.0 & 99.1 & 93.8 & 91.7 & 90.3 \\
\hline Wetzel & 85.9 & 100.0 & 114.2 & 25.3 & 95.3 & 94.5 & 88.3 \\
\hline Wirt & 72.9 & 100.0 & 102.1 & 83.3 & 81.2 & 85.4 & 81.2 \\
\hline Wond & 7.5 & 100.0 & 108.7 & 94.6 & 92.9 & 88.0 & 80.4 \\
\hline Wyoming & 62.1 & 100.0 & 93.1 & 79.3 & 80.2 & 83.6 & 87.9 \\
\hline TOTAL & 67.0 & 100.0 & 103.8 & 91.4 & 89.0 & 89.12 & 86.2 \\
\hline
\end{tabular}

Section III WELFARE
W. Va. Unir.

Agr. Exp. Sta.

Bul. No. 464 
TABLE 4A. THE AMOUNTS (IN THOUSANDS OF DOLLARS) OF TRANSFER

PAYMENTS PAID THROUGH THE PROGRAMS OF AID FOR DEPENDENT

CHILDREN TO RECIPIENTS IN THE COUNTIES OF WEST VIRGINIA

The information presented here was taken from the annual reports of the Department of Public Assistance, State of West Virginia.

Section III

WELFARE

\begin{tabular}{|c|c|c|c|c|c|c|c|}
\hline COUNTY & 1940 & 1950 & 1955 & 1957 & 1958 & 1959 & 1960 \\
\hline Basbour & 25 & 221 & 232 & 243 & 239 & 249 & 230 \\
\hline Berkeley & 15 & 57 & 79 & 70 & 96 & 125 & 134 \\
\hline Boone & 21 & 138 & 436 & 437 & 463 & 502 & 493 \\
\hline Braxton & 32 & 306 & 345 & 371 & 358 & 370 & 362 \\
\hline Brooke & 16 & 42 & 59 & 55 & 64 & 76 & 82 \\
\hline Cabell & 66 & 207 & 220 & 272 & 338 & 427 & 457 \\
\hline Calhoun & 13 & 183 & 95 & 107 & 129 & 151 & 154 \\
\hline Clay & 28 & 242 & 353 & 339 & 356 & 392 & 367 \\
\hline Daddridge & 10 & 73 & 64 & 59 & 56 & 67 & 60 \\
\hline Fayette & 82 & 278 & 731 & 841 & 916 & 1,030 & 1,039 \\
\hline Gilmer & 8 & 122 & 182 & 168 & 175 & 191 & 185 \\
\hline Grant & 9 & 46 & 69 & 62 & 69 & 69 & 77 \\
\hline Greenbrier & 34 & 316 & 365 & 313 & 298 & 337 & 326 \\
\hline Hamp shire & 13 & 66 & 101 & 84 & 88 & 103 & 108 \\
\hline Hancock & 12 & 46 & 44 & 41 & 49 & 54 & 60 \\
\hline Hardy & 13 & 55 & 66 & 68 & 74 & 85 & 82 \\
\hline Harrison & 42 & 104 & 93 & 89 & 94 & 106 & 101 \\
\hline Jacksoo & 17 & 98 & 144 & 157 & 152 & 170 & 178 \\
\hline Jefferson & 17 & 51 & 56 & 78 & 93 & 113 & 118 \\
\hline Kanawha & 190 & 696 & 1,842 & 2,096 & 1,980 & 2,002 & 1,817 \\
\hline Lewis & 12 & 138 & 205 & 222 & 234 & 263 & 270 \\
\hline Lincola & 34 & 309 & 512 & 517 & 569 & 641 & 668 \\
\hline Logaa & 60 & 297 & 992 & 1,033 & 1,113 & 1,310 & 1,350 \\
\hline McDowell & 86 & 451 & 1,192 & 1.276 & 1,375 & 1,732 & 1,907 \\
\hline Marion & 53 & 176 & 180 & 212 & 216 & 249 & 250 \\
\hline MarshalI & 40 & 171 & 171 & 179 & 173 & 201 & 206 \\
\hline Mason & 19 & 73 & 108 & 110 & 139 & 160 & 162 \\
\hline Mercer & 65 & 344 & 715 & 922 & 1,010 & 1,220 & 1,399 \\
\hline Mineral & 19 & 82 & 137 & 137 & 141 & 151 & 146 \\
\hline Mingo & 43 & 492 & 796 & 786 & 862 & 1,018 & 1,088 \\
\hline Monongalia & 35 & 120 & 175 & 158 & 166 & 186 & 182 \\
\hline Monroe & 15 & 104 & 163 & 177 & 196 & 211 & 215 \\
\hline Morgan & 20 & 46 & 50 & 46 & 51 & 71 & 82 \\
\hline Nicholas & 41 & 217 & 415 & 411 & 416 & 443 & 427 \\
\hline Ohio & 33 & 156 & 227 & 206 & 226 & 286 & 311 \\
\hline Pendleton & 10 & 78 & 134 & 122 & 128 & 136 & 137 \\
\hline Pleasaots & 6 & 34 & 45 & 47 & 46 & 56 & 54 \\
\hline Pocahontas & 15 & 103 & 119 & 122 & 135 & 148 & 144 \\
\hline Preston & 40 & 167 & 172 & 150 & 149 & 165 & 156 \\
\hline Putnam & 22 & 138 & 208 & 211 & 209 & 227 & 212 \\
\hline Raleigh & 99 & 397 & 830 & 789 & 766 & 822 & 890 \\
\hline Randolph & 40 & 210 & 277 & 305 & 309 & 318 & 322 \\
\hline Ritchie & 20 & 86 & 74 & 87 & 95 & 109 & 113 \\
\hline Roane & 25 & 67 & 140 & 177 & 198 & 243 & 277 \\
\hline Sommers & 31 & 247 & 442 & 427 & 432 & 494 & 516 \\
\hline Taylor & 16 & 94 & 77 & 67 & 65 & 75 & 71 \\
\hline Tucker & 17 & 117 & 142 & 127 & 126 & 128 & 121 \\
\hline Tyler & 9 & 70 & 120 & 128 & 136 & 146 & 143 \\
\hline Upshux & 23 & 149 & 200 & 234 & 266 & 314 & 334 \\
\hline Wayoe & 60 & 514 & 701 & 770 & 825 & 896 & 931 \\
\hline Webster & 33 & 193 & 410 & 401 & 392 & 420 & 424 \\
\hline WetzeI & 33 & 208 & 255 & 231 & 214 & 224 & 230 \\
\hline Wirt & 7 & 44 & 42 & 49 & 44 & 44 & 42 \\
\hline Wood & 46 & 261 & 342 & 340 & 351 & 405 & 415 \\
\hline Wyoming & 52 & 241 & 442 & 475 & 522 & 614 & 701 \\
\hline TOTAL & 1,842 & 9,941 & 16,786 & 17,601 & 18,382 & 20,745 & 21,326 \\
\hline
\end{tabular}

W. Va. Unir.

Agr. Exp. Sto.

Bul. No. 464

Page 40 
TABLE 4B. THE AMOUNTS (IN THOUSANDS OF DOLLARS, AD JUSTED BY THE WHOLESALE COMMODITY INDEX) OF TRANSFER PAYMENTS PAID THROUGH THE PROGRAM OF AID FOR DEPENDENT CHILDREN TO RECIPIENTS IN THE COUNTIES OF WEST VIRGINIA

Data presented here are based on those in the previous table,

Table 4A, Section III.

\begin{tabular}{|c|c|c|c|c|c|c|c|}
\hline COUNTY & 1940 & 1950 & 1955 & $195 ?$ & 1958 & 1959 & 1960 \\
\hline Barbour & 49 & 214 & 210 & 207. & 200 & 209 & 193 \\
\hline Berkeley & 29 & 55 & 71 & 60 & 81 & 105 & 112 \\
\hline Boone & 41 & 134 & 394 & 372 & 388 & 420 & 413 \\
\hline Braxton & 63 & 297 & 312 & 375 & 300 & 310 & 303 \\
\hline Brooke & 31 & 41 & 53 & 117 & 54 & 64 & 69 \\
\hline Cabell & 129 & 201 & 199 & 231 & 284 & 358 & 383 \\
\hline Calhoun & 25 & 177 & 86 & 97 & 108 & 126 & 129 \\
\hline Clay & 55 & 235 & 319 & 288 & 299 & 328 & 307 \\
\hline Doddridge & 20 & 71 & 58 & 50 & 47 & 56 & 50 \\
\hline Fayette & 160 & 270 & 660 & 715 & 768 & 863 & 870 \\
\hline Gilmer & 16 & 118 & 164 & $1 \longdiv { 3 }$ & 147 & 160 & 155 \\
\hline Grant & 18 & 1,5 & 62 & 53 & 58 & 58 & 64 \\
\hline Greeabrier & 67 & 306 & 330 & 266 & 250 & 282 & 273 \\
\hline Hampshire & 25 & 64 & 91 & 71 & 74 & 86 & 90 \\
\hline Hancock & 23 & 45 & 40 & 35 & L1. & 1,5 & 50 \\
\hline Hardy & 25 & 53 & 60 & 58 & 62 & 71 & 69 \\
\hline Harrisoo & 82 & 101 & 84 & 76 & 79 & 89 & 85 \\
\hline Jacksoa & 33 & 95 & 130 & 134 & 128 & 142 & 149 \\
\hline Jeffersoo & 33 & 49 & 51 & 66 & 78 & 95 & 99 \\
\hline Kanawha & 372 & 675 & 1,664 & 1,782 & 1,661 & 1.677 & 1,522 \\
\hline Lewis & 23 & 134 & 185 & 189 & 196 & 220 & 226 \\
\hline Lincola & 67 & 300 & 463 & 440 & 177 & 537 & 559 \\
\hline Logan & 117 & 288 & 896 & 878 & 934 & $1,09 ?$ & 1,131 \\
\hline McDowell & 168 & 437 & 1,077 & 1,085 & 1,154 & 1,451 & 1,597 \\
\hline Marioo & 104 & 171 & 163 & 180 & 181 & 209 & 209 \\
\hline Marshall & 78 & 166 & 154 & 152 & 11,5 & 168 & 173 \\
\hline Mason & 37 & 71 & 98 & 94 & 117 & 134 & 136 \\
\hline Mercer & 127 & 334 & 646 & 784 & 847 & 1,022 & 1,172 \\
\hline Mineral & 37 & 80 & 124 & 116 & 378 & 126 & 122 \\
\hline Mingo & 84 & 477 & 719 & 668 & 723 & 853 & 911 \\
\hline Mooongalia & 68 & 116 & 158 & 13i & 139 & 156 & 152 \\
\hline Monroe & 29 & 101 & 117 & 151 & 164 & 177 & 180 \\
\hline Morgan & 39 & 15 & 45 & 39 & 13 & 59 & 69 \\
\hline Nicholas & 80 & 210 & 375 & 349 & 319 & 371 & 358 \\
\hline Ohio & 65 & 151 & 205 & 775 & 190 & 240 & 260 \\
\hline Peadleton & 20 & 76 & 121 & 101 & 107 & $12 \%$ & 215 \\
\hline Pleasaots & 12 & 33 & 12 & 10 & 39 & 17 & 1,5 \\
\hline Pocahootas & 29 & ino & $10 ?$ & 104 & 113 & $12 h$ & 121 \\
\hline Preston & 78 & 162 & 155 & 128 & 125 & 138 & 131 \\
\hline Putnam & 43 & 134 & 188 & 179 & 275 & 190 & 178 \\
\hline Raleigh & 194 & 385 & 750 & 671 & 64,3 & 688 & 7.5 \\
\hline Randolph & 78 & 204 & 250 & 259 & 259 & 266 & 270 \\
\hline Ritchie & 39 & 83 & 67 & 74 & 80 & 91 & 25 \\
\hline Roaoe & 49 & 65 & 126 & 151 & 166 & 204 & 232 \\
\hline Summers & 61 & 240 & 399 & 363 & 362 & 1.14 & 432 \\
\hline Taylor & 31 & 91 & 70 & 57 & 55 & 63 & 59 \\
\hline Tucker & 33 & 113 & 128 & 108 & 106 & 107 & 101 \\
\hline Tylet & 18 & 68 & 108 & 109 & 114 & 122 & 120 \\
\hline Upshur & 45 & 15 & 781 & 299 & 223 & 263 & 280 \\
\hline Wayae & $11 ?$ & 499 & 633 & 655 & 692 & 750 & 780 \\
\hline Webster & 65 & 187 & 370 & 3) & 329 & 352 & 355 \\
\hline Wetzel & 65 & 202 & $23 n$ & 196 & 180 & 188 & 193 \\
\hline Wirt & 14 & 43 & 38 & 42 & 37 & 37 & 35 \\
\hline Wood & 90 & 253 & 309 & 287 & 221 & 339 & 348 \\
\hline Wyoming & 102 & 234 & 399 & 1001 & 438 & 52 & 587 \\
\hline TOTAL & 3605 & 96112 & 15,164 & $14,26 ?$ & 15,121 & 17,374 & 17,861 \\
\hline
\end{tabular}

Section III WELFARE

W. Va. Univ.

Agr. Exp. Sta. Bul. Na. 464

Page 47 


\section{TABLE 4C. INDEX OF THE AMOUNTS OF TRANSFER PAYMENTS (ADJUSTED BY THE WHOLESALE COMMODITY INDEX) IN THE AID FOR DEPENDENT CHILDREN PROGRAM IN THE COUNTIES OF WEST VIRGINIA $1950=100$}

This index was prepared from the data in the preceding table, Table $4 \mathrm{~B}$, Section III.

Section III

WELFARE

W. Ya. Univ.

Agr. Exp. Sto

Bul, No. 464

Page 42

\begin{tabular}{|c|c|c|c|c|c|c|c|}
\hline COUNTY & 1940 & 1950 & 1955 & 1957 & 1958 & 1959 & 1960 \\
\hline Barbour & 22.9 & 100.0 & 98.1 & 96.7 & 93.5 & 97.7 & 90.2 \\
\hline Betkeley & 52.7 & 100.0 & 129.1 & 109.1 & 147.3 & 190.9 & 203.6 \\
\hline Boone & 30.6 & 100.0 & 294.0 & 277.6 & 289.6 & 313.4 & 308.2 \\
\hline Braxton & 21.2 & 100.0 & 105.0 & 106.1 & 101.0 & 204.4 & 102.0 \\
\hline Brooke & 75.6 & 100,0 & 129.3 & $11 / 1.6$ & 137.7 & 156.7 & 168.3 \\
\hline Cabell & 64.2 & 100.0 & 99.0 & 114.9 & 111.3 & 178.1 & 190.5 \\
\hline Calhoug & 14.1 & 100.0 & 18.6 & 51.4 & 61.0 & 732 & 72.9 \\
\hline Clay & 23.4 & 100.0 & 135.7 & 122.6 & 127.2 & 139.6 & 130.6 \\
\hline Doddridge & 28.2 & 100.0 & 81.7 & 70.4 & 66.2 & 78.9 & 70.4 \\
\hline Fayette & 59.3 & 100.0 & 244.4 & 264.8 & 284.14 & 319.6 & 322.2 \\
\hline Gilmer & 13.6 & 100.0 & 139.0 & 121.2 & 124.6 & 135.6 & 131.4 \\
\hline Grant & 40.0 & 100.0 & 137.8 & 117.8 & 128.9 & 128.9 & 142.2 \\
\hline Greenbrier & 21.9 & 100.0 & 107.8 & 86.9 & 81.7 & 92.2 & 89.2 \\
\hline Hampshire & 39.1 & 100.0 & 142.2 & 110.9 & 115.6 & 134.4 & 140.6 \\
\hline Haacnck & 51.1 & 100.0 & 88.9 & 77.8 & 91.1 & 100.0 & 171.1 \\
\hline Hardy & $1,7.2$ & 100.0 & 113.2 & 109. & 117.0 & 134.0 & 130.2 \\
\hline Harrisoo & 81.2 & 100.0 & 83.2 & 75.2 & 78.2 & 88.1 & 84.2 \\
\hline Jackson & 34.7 & 100.0 & 136.8 & $1,1.1$ & 134.7 & 149.5 & 156.8 \\
\hline Jeffersno & 67.3 & 100.0 & 101.9 & 134.7 & $159 . ?$ & 193.9 & 202.0 \\
\hline Kanawha & 55.1 & 100.2 & 246.5 & 26.0 & 26.1 & 248.4 & 225.5 \\
\hline Lewis & 17.2 & 100.0 & 138.1 & 1) 1.0 & 1.6 .3 & 164.2 & 168.7 \\
\hline Lincaln & 22.3 & 100.0 & $15 / .3$ & 146.7 & 159.1 & 179.0 & 186.3 \\
\hline Logan & 40.6 & 100.0 & 311.1 & 301.9 & 324.3 & 380.9 & 392.7 \\
\hline McDowell & 38.1 & 100.0 & 246.5 & 248.3 & 261.1 & 332. & 365.4 \\
\hline Marion & 60.8 & 100.0 & 95.3 & 105.3 & 105.8 & 122.2 & 122.2 \\
\hline Marshall & 47.0 & 100.0 & 92.8 & 91.6 & 87.3 & 101.2 & 104.2 \\
\hline Mason & 52.1 & 100.0 & 138.0 & 132.4 & 164.8 & 188.7 & 191.5 \\
\hline Mercer & 38.0 & 100.0 & 193.4 & 231.7 & 253.6 & 306.0 & 350.9 \\
\hline Mineral & 116,2 & 100.0 & 155.0 & 115.0 & 177.5 & 157.5 & 152.5 \\
\hline Mingo & 17.6 & 100.0 & 150.7 & 140.0 & 151.6 & 178.8 & 191.0 \\
\hline Monongalia & 58.6 & 700.0 & 136.2 & 115.5 & 119.8 & 131.5 & 131.0 \\
\hline Moorne & 28.7 & 100.0 & 145.5 & 19.5 & 162.11 & 175.2 & 178.2 \\
\hline Morgan & 86.7 & 100.0 & 100.0 & 86.7 & 95.6 & 132.7 & 153.3 \\
\hline Nicholas & 38.1 & 100.0 & 278.6 & 166.2 & $166 . ?$ & 176.7 & 170.5 \\
\hline Ohio & 43.0 & 100.0 & 135.8 & 175.9 & 125.8 & 158.9 & 172.2 \\
\hline Pendleton & 26.3 & 100.0 & 159.2 & 136.8 & 110.8 & 150.0 & 151.3 \\
\hline Pleasaats & 36.1 & 100.0 & 124.2 & 121.2 & 118.2 & 142.1 & 136.11 \\
\hline Pocahontas & 27.0 & 100.0 & 107.0 & 10.0 & 113.0 & 124.0 & 121.0 \\
\hline Preston & 18.1 & 100.0 & 95.7 & 79.0 & 77.2 & 85.2 & 80.9 \\
\hline Patnam & 32.1 & 100.0 & 110.3 & 133.6 & 130.6 & 11.8 & 132.8 \\
\hline Raleigh & 50.4 & 100.0 & 191.8 & 174.3 & 167.0 & 238.7 & 193.5 \\
\hline Randolph & 38.2 & 100.0 & 122.5 & 127.0 & 127.0 & 130.1 & 132.4 \\
\hline Ritchie & 12.0 & 100.0 & 80.7 & 89.2 & $96 . h$ & 109.6 & $11 / .5$ \\
\hline Roane & 75.4 & 100.0 & 193.8 & 232.3 & 255.4 & 313.8 & 356.9 \\
\hline Summers & 25.1 & 100.0 & 166.2 & $151 . ?$ & 150.8 & 172.5 & 180.0 \\
\hline Taylor & 3.1 & 100.0 & 76.9 & 62.6 & 60.4 & 69.2 & 64.8 \\
\hline Tucker & 29.2 & 100.0 & 113.3 & 95.6 & 93,8 & 94.7 & 89.4 \\
\hline Tyler & 26.5 & 100.0 & 158.9 & 160.3 & 167.6 & 179.4 & 176.5 \\
\hline Upshar & 31.0 & 100.0 & 121.8 & 137.2 & 153.9 & 181.) & 193.0 \\
\hline Wayne & 23.4 & 100.0 & 126.9 & 131.3 & 130.7 & 150.3 & 156.3 \\
\hline Webster & 34.8 & 100.0 & 197.9 & 182.4 & 175.9 & 188.2 & 189.8 \\
\hline Wetzel & 32.2 & 100.0 & 113.9 & 97.0 & 89.1 & 93.1 & 95.5 \\
\hline Wirt & 32.6 & 100.0 & 88.11 & 97.7 & 86.0 & 86.0 & 81.4 \\
\hline Food & 35.6 & 100.0 & 122.1 & 111.2 & 116.2 & 134.0 & 137.5 \\
\hline Wyoming & 43.6 & 100.0 & 170.5 & 172.6 & 187.2 & 219.7 & 250.9 \\
\hline TOTAL & 37.4 & 100.0 & 157.3 & 155.2 & 159.9 & 180.2 & 185.2 \\
\hline
\end{tabular}




\section{Section IV}

\section{EDUCATION}

Toble

IA The Total Amounts (in Thousands of Dollars) Expended for Public School Education in the Counties of West Virginia ....

IB A Moving Average of Total Expenditures (in Thousands of Dollars, Adjusted by the Wholesale Commodity Index) for Public School Education in the Counties of West Virginia ....

IC Index of the Moving Average of Total Expenditures (Adjusted by the Wholesale Commodity Index) for Public School Education in the Counties of West Virginia ....

2A A Comparison of the Total Expenditures for Public School Education in the Counties of West Virginia and the Total Personal Income: Expenditures are Given as a Percentage of Total Personal Income $\ldots .$.

Index of a Comparison Between Total Expenditures for Public School Education in the Counties of West Virginia and the Total Personal Income in the Counties of West Virginia, $1950=100$

The Expenditures (in Thousands of Dollars) for Instructional Purposes in the Public Schools in the Counties of West Virginia

The Expenditures (in Thousands of Dollars, Adjusted by the Wholesale Commodity Index) for Instructional Purposes in the Counties of West Virginia ....

Index of the Expenditures (Adjusted by the Wholesale Commodity Index) for Instructional Purposes in the Counties of West Virginia, $1950=100 \ldots \ldots$

4A Average Daily Attendance in Public Schools in the Counties of West Virginia ....

4B Index of the Average Daily Attendance in the Public Schools in the Counties of West Virginia, I950 $=100 \ldots$.

5A The Relationship Between Number of Sophomores of the Previous Years to the Number of Juniors of the Specified Year Enrolled in High Schools for the Counties of West Virginia: The Relationship is Expressed as the Percentage of Juniors to Sophomores

Index of the Relationship Between the Number of Sophomores of the Previous Year to the Number of Juniors of the Specified Year Enrolled in High Schools for the Counties of West Virginia 
TABLE IA. THE TOTAL AMOUNTS (IN THOUSANDS OF DOLLARS)EXPENDED FOR PUBLIC SCHOOL EDUCATION IN THE COUNTIES OF WEST VIRGINIA

Data presented in this table were compiled from the Annual

Report of the State Superintendent of Free Schools.

Section IV

EDUCATION

W. Va. Univ.

Agr. Exp. Sta.

Bul. No. 464

\begin{tabular}{|c|c|c|c|c|c|c|c|}
\hline COUNTY & $39-40$ & $49-50$ & $54-55$ & $56-57$ & $57-58$ & $58-59$ & $59-60$ \\
\hline Barbour & 284 & 715 & 720 & $86 / 1$ & 875 & 858 & 835 \\
\hline Berkeley & 348 & 933 & 1,064 & $1,4,1$ & 1,403 & 1,455 & 1,508 \\
\hline Bonne & 406 & 1,057 & $1,1,68$ & 1.819 & 1,886 & 1,926 & 1,808 \\
\hline Braxton & 323 & 659 & 740 & 895 & 922 & $9 /, 3$ & 941 \\
\hline Bronke & 467 & 840 & 1,388 & 1,399 & 1,323 & 1,363 & 1,544 \\
\hline Cahell & 1.671 & 4,299 & 4.611 & 4.952 & 5.487 & 5,814 & 6,414 \\
\hline CsIhoun & 212 & 465 & 415 & 195 & 525 & 535 & 515 \\
\hline Clay & 209 & -535 & 642 & 718 & 810 & 787 & 810 \\
\hline Doddridge & 269 & 527 & 460 & 527 & 529 & 508 & 517 \\
\hline Fayette & 1,117 & 2,970 & 3,464 & 3,929 & 3,943 & 3,918 & 4.518 \\
\hline Gilmer & 196 & 472 & 454 & .764 & 547 & 193 & 488 \\
\hline Grant & $1 / 10$ & 315 & 399 & 490 & L9\% & 4.55 & 489 \\
\hline Greenhrier & 570 & 1,434 & 1,476 & 1,719 & 1.830 & 1,879 & 2,043 \\
\hline Hampshire & 175 & 481 & 567 & 600 & 617 & 633 & 607 \\
\hline Hancack & 504 & 1.073 & 1,425 & 1,770 & 1,866 & 2,554 & 3,375 \\
\hline Hardy & 16) & 121 & 511 & 552 & 511 & 559 & 638 \\
\hline Harrison & 1,056 & 2,597 & $2,81 \overline{3}$ & 3,280 & 3,598 & 4,403 & 4,335 \\
\hline Jackson & $2 / 6$ & 836 & 619 & 766 & 809 & 891 & 1,157 \\
\hline Jeffersan & 194 & 598 & 747 & 1,306 & 1,494 & 1,111 & 1,061 \\
\hline Kanawha & 3,571 & 8,106 & 13.749 & 12,183 & 12,628 & 14,114 & 16,878 \\
\hline Lewis & 316 & 724 & 778 & 910 & 1,122 & 1.035 & 1,087 \\
\hline Lincoln & 354 & 973 & 1,155 & 1.367 & 1,320 & 1,306 & $1,4,79$ \\
\hline Logan & 2,5 & 2,319 & 3,871 & 1.709 & 4,472 & 4,818 & 4,832 \\
\hline McDowell & 1,627 & 3,260 & 4.239 & 16.792 & 5,778 & 5,341 & 5,579 \\
\hline Marino & 94/4 & 2,218 & 2,479 & 2,842 & 3.119 & 3,326 & 3.452 \\
\hline Marshall & 524 & 945 & 1,643 & 1,780 & 1.609 & 1,568 & 2,174 \\
\hline Masnn & 346 & 772 & 1,072 & 1.520 & 1.189 & 1,293 & $1,4,30$ \\
\hline Mercer & 969 & 2,712 & 3,461 & 6,069 & 3,872 & 3,969 & 4,029 \\
\hline Mineral & 257 & 671 & 222 & 1,118 & 1,215 & 1,202 & 1,288 \\
\hline Mingo & 723 & 1,811 & 2,685 & 2,613 & 2,769 & 2,729 & 3,137 \\
\hline Monongal ia & 827 & 2.099 & 3,359 & $2,8,3$ & 2.822 & 3,032 & 3,181 \\
\hline Monroe & 216 & 556 & 568 & 670 & 672 & 667 & 673 \\
\hline Morgan & 148 & 336 & 364 & 728 & 538 & $5 \longdiv { 3 3 }$ & 537 \\
\hline Nichalas & 327 & 265 & 1,102 & 1,395 & 1,499 & $1,5]^{14}$ & 1,625 \\
\hline Ohio & 1,073 & 1,968 & 2,178 & 2.598 & 2,819 & 2.851 & 2,9311 \\
\hline Pendleton & 210 & 394 & 40 & 181 & 526 & 480 & 525 \\
\hline Pleasants & 105 & 246 & 787 & 403 & 453 & 465 & 638 \\
\hline Pocahontaa & 234 & $5 \longdiv { 1 0 }$ & 542 & 587 & 563 & 593 & 608 \\
\hline Preston & 519 & 1,332 & 1,195 & 1,670 & 1,722 & 1,730 & 1,809 \\
\hline Potnam & 301 & 654 & 965 & 1,120 & 1.249 & 1.236 & 1.367 \\
\hline Raleigh & 1,282 & 3,325 & 4,158 & 4,669 & 4,894 & 4,868 & 5,211 \\
\hline Randolph & 150 & 1,161 & 1,352 & 1,498 & 1,522 & 1.517 & 1.546 \\
\hline Ritchie & 260 & 576 & 536 & 566 & 587 & 613 & 613 \\
\hline Roane & 307 & 785 & 693 & 812 & 80 & 794 & 851 \\
\hline Summers & 317 & 703 & 806 & 918 & 221 & 990 & 922 \\
\hline Taylor & 252 & 575 & 625 & 225 & 710 & 756 & 757 \\
\hline Tncker & 220 & 463 & 432 & 55 & 496 & 500 & 509 \\
\hline Tyler & 182 & 489 & 152 & 533 & 533 & 544 & 620 \\
\hline Upshnr & 288 & 641 & 756 & 1,178 & 1,517 & 1.092 & 1.055 \\
\hline Wayne & 551 & 1,112 & 1,706 & 1,999 & 2,367 & 2,213 & 2,333 \\
\hline Wehster & 281 & 647 & 1,046 & 858 & 856 & 819 & 861 \\
\hline Wetzel & 374 & 729 & 954 & 1.072 & 1.259 & 2,033 & 1,489 \\
\hline Wirt & 111 & 270 & 237 & 256 & 379 & 267 & 287 \\
\hline Wood & 782 & 1,896 & 2,199 & 4,789 & 4,024 & 3,439 & 4,299 \\
\hline Wyoming & 560 & 1,626 & 1.894 & 2,258 & 2.527 & 2,673 & 3,926 \\
\hline TOTAL & 29,364 & 39.936 & 89,953 & 103,341 & $10+, 808$ & 109,035 & 18,848 \\
\hline
\end{tabular}


TABLE IB. A MOVING AVERAGE OF TOTAL EXPENDITURES (IN THOUSANDS OF DOLLARS, ADJUSTED BY THE WHOLESALE COMMODITY INDEX) FOR

PUBLIC SCHOOL EDUCATION IN THE COUNTIES OF WEST VIRGINIA

\begin{tabular}{|c|c|c|c|c|c|c|c|}
\hline COUNTY & 1940 & 1950 & 1955 & 1956 & 1957 & 1958 & 1950 \\
\hline Barbour & 561 & 655 & 668 & 687 & 715 & 733 & 718 \\
\hline Berkeley & 696 & 888 & 1251 & 1319 & 1391 & 1213 & 1221 \\
\hline Boone & 807 & 1066 & 1348 & 1427 & 1513 & 1589 & 1572 \\
\hline Braxton & 612 & 635 & 706 & 744 & 779 & 779 & 785 \\
\hline Brooke & 935 & 812 & 1228 & 1214 & 1165 & 1154 & 1783 \\
\hline Cabell & 3071 & 3735 & 4064 & 4176 & 4321 & 4585 & 1955 \\
\hline Calhoun & 390 & 454 & 4.12 & 400 & 422 & 139 & 440 \\
\hline Clay & 417 & 528 & 593 & 599 & 632 & 653 & 673 \\
\hline Doddridge & 441 & 445 & 419 & 429 & 438 & 442 & 435 \\
\hline Fayette & 2169 & 2822 & 3356 & 3174 & 3233 & 3328 & 3462 \\
\hline Gilmer & 390 & 442 & 451 & 527 & 543 & 510 & 128 \\
\hline Grant & 268 & 365 & 364 & 381 & 399 & 406 & 102 \\
\hline Green brier & 1097 & 1301 & 1348 & 1381 & 1448 & 1532 & 1609 \\
\hline Hampshise & 351 & 433 & 488 & 503 & 505 & 522 & 519 \\
\hline Haocock & 889 & 1004 & 1420 & 1465 & 1557 & 1745 & 2179 \\
\hline Hardy & 346 & 4.17 & 460 & 468 & 468 & $\frac{.14}{469}$ & $\frac{1+1}{489}$ \\
\hline Harrison & 2132 & 2392 & 2617 & 2738 & 2897 & 3181 & 3450 \\
\hline Jackson & 487 & 724 & 579 & 603 & 643 & 696 & 799 \\
\hline Jeffersoa & 394 & 587 & 701 & 853 & 1047 & 1105 & 1026 \\
\hline Kanawha & 6683 & 7517 & 12168 & 10953 & 10336 & 10981 & 12199 \\
\hline Lewis & 641 & 666 & 764 & 796 & 875 & 865 & 908 \\
\hline Lincola & 673 & 798 & 1101 & 1076 & 1097 & 1127 & 1148 \\
\hline Logan & 1786 & 2214 & 4394 & 3897 & 3981 & 3952 & 3950 \\
\hline McDowell & 2919 & 3141 & 3776 & 3822 & 4161 & 4488 & 4671 \\
\hline Marion & 1780 & 2099 & 2269 & 2325 & 2450 & 2620 & 2768 \\
\hline Marshall & 994 & 952 & 1554 & 1689 & 1644 & 2400 & 1497 \\
\hline Mason & 642 & 839 & 986 & 1093 & 1102 & 1137 & 1094 \\
\hline Mercer & 1860 & 2468 & 3415 & 4214 & 1,238 & 3921 & 3305 \\
\hline Mineral & 526 & 674 & 849 & 881 & 943 & 997 & 1036 \\
\hline Mingo & 1439 & 1669 & 2386 & 2261 & 2226 & 2289 & 2415 \\
\hline Monongalia & 1547 & $195 \mathrm{~L}$ & 2983 & 2768 & $25 \lcm{43}$ & 2455 & 2527 \\
\hline Montoe & 426 & 505 & 534 & 547 & 563 & 567 & 563 \\
\hline Margan & 297 & 312 & 412 & 509 & 550 & 511 & 452 \\
\hline Nicholas & 648 & 937 & 101 & 2085 & 1.172 & 12L4 & 1297 \\
\hline Ohio & 2058 & 1947 & 2209 & 2210 & 2251 & 2333 & 2407 \\
\hline Peadleton & 410 & 393 & 393 & 413 & 436 & 421. & 428 \\
\hline Pleasants & 207 & 304 & 493 & 497 & 386 & 373 & 435 \\
\hline Pocahontas & 461 & 517 & 484 & 483 & 477 & 492 & 493 \\
\hline Preston & 996 & 1259 & 1382 & $\mathrm{IHO}_{4}$ & $\sqrt{35}$ & 1446 & 1472 \\
\hline Putnam & 581 & 729 & 1060 & 926 & 984 & 1017 & 1077 \\
\hline Raleigh & 2365 & 3230 & 3937 & 3796 & 3912 & 4073 & 4188 \\
\hline Randolph & 927 & 1.170 & 1358 & 1231 & $1 2 \longdiv { 1 9 }$ & $\frac{4013}{1281}$ & 1283 \\
\hline Ritcbie & 532 & 5.15 & 189 & 483 & 485 & 507 & 516 \\
\hline Roane & 582 & 762 & 629 & 651 & 667 & 680 & 685 \\
\hline Summers & 713 & 662 & 792 & 758 & 773 & 798 & 792 \\
\hline Taylor & 495 & 51.5 & 575 & 584 & 591 & 615 & $\frac{126}{622}$ \\
\hline Tucker & 500 & 1,24 & 398 & 411 & 420 & 126 & 421 \\
\hline Tyler & 359 & 422 & 413 & 433 & 445 & 455 & 475 \\
\hline Upsbur & 560 & 626 & 693 & 802 & 998 & 1069 & 2025 \\
\hline Wayne & 1156 & 1122 & 2577 & 1671 & 1879 & 1856 & 1934 \\
\hline Webster & 565 & 566 & 854 & 806 & 730 & 725 & 700 \\
\hline Wetzel & 711 & 706 & 876 & 886 & 951 & $12 \sqrt{3}$ & 1351 \\
\hline Wirt & 210 & 252 & 217 & 213 & 248 & 254 & 261 \\
\hline Wood & 1519 & 2752 & 2197 & 2909 & 3374 & 3464 & 34,86 \\
\hline Wyoming & 1084 & 1203 & $181 \%$ & 1794 & 1930 & 2087 & 2535 \\
\hline TOTAL & 56,310 & 65,754 & 83,943 & 82.363 & 86.562 & 89.239 & 02,772 \\
\hline
\end{tabular}

Section IV EDUCATION w. Va. Univ.

Agr. Exp. Sta. Bul. No. 464

Page 45 
TABLE 1C. INDEX OF THE MOVING AVERAGE OF TOTAL EXPENDITURES (ADJUSTED BY THE WHOLESALE COMMODITY INDEX) FOR PUBLIC SCHOOL EDUCATION IN THE COUNTIES OF WEST VIRGINIA

Data presented in this table are based on those presented in the preceding table, Table $1 B$, Section IV.

Section IV EDUCATION

W. Ya. Univ. Agr. Exp. Sta. Bul. Na. 464

Page 46

\begin{tabular}{|c|c|c|c|c|c|c|c|}
\hline COUNTY & 1940 & 1950 & 1955 & 1956 & 1957 & 1958 & 1959 \\
\hline Barbour & 86 & 100.0 & 102 & 105 & 109 & 112 & 110 \\
\hline Berkeley & 78 & 100.0 & 141 & 149 & 157 & 137 & 138 \\
\hline Boone & 76 & 100.0 & 126 & 134 & 142 & 149 & 147 \\
\hline Braxtno & 96 & 100.0 & 111 & 117 & 123 & 123 & 124 \\
\hline Brooke & 115 & 100.0 & 151 & 150 & 143 & 142 & 146 \\
\hline Cabell & 82 & 100.0 & 109 & 112 & 116 & 123 & 133 \\
\hline Calhoun & 86 & 100.0 & 91 & 88 & 93 & 97 & 97 \\
\hline Clay & 79 & 100.0 & 112 & 113 & 120 & 124 & 127 \\
\hline Doddridge & 99 & 100.0 & 94 & 96 & 98 & 99 & 98 \\
\hline Fayette & 77 & 100.0 & 119 & 112 & 115 & 118 & 123 \\
\hline Gilmer & 88 & 100.0 & 102 & 119 & 123 & 115 & 97 \\
\hline Grant & 73 & 100.0 & 100 & 104 & 109 & 111 & 110 \\
\hline Greenbrier & 84 & 100.0 & 104 & 106 & 111 & 118 & 124 \\
\hline Hampshire & 81 & 100.0 & 113 & 116 & 117 & 121 & 120 \\
\hline Hancock & 89 & 100.0 & 141 & 146 & 155 & 174 & 217 \\
\hline Hardy & 83 & 100.0 & 110 & 112 & 112 & -112 & 117 \\
\hline Harrison & 89 & 100.0 & 109 & 114 & 121 & 133 & 144 \\
\hline Jackson & 67 & 100.0 & 80 & 83 & 89 & 96 & 110 \\
\hline Jefferson & 67 & 100.0 & 119 & 145 & 178 & 188 & 175 \\
\hline Kanawha & 8.2 & 100.0 & 162 & 146 & 138 & 146 & 162 \\
\hline Lewis & 96 & 100.0 & 115 & 120 & 131 & 130 & 136 \\
\hline Lincolo & 84 & 100.0 & 138 & 135 & 137 & 141 & 144 \\
\hline Logan & 81 & 100.0 & 198 & 176 & 180 & 178 & 178 \\
\hline McDowell & 93 & 100,0 & 120 & 122 & 132 & 143 & 149 \\
\hline Marion & 85 & 100.0 & 108 & 111 & 117 & 125 & 132 \\
\hline Marshall & 104 & 100.0 & 163 & 177 & 173 & 147 & 157 \\
\hline Masoo & 77 & 100.0 & 118 & 130 & 131 & 136 & 130 \\
\hline Metcer & 75 & 100.0 & 138 & 171 & 172 & 159 & 134 \\
\hline Mineral & 78 & 100.0 & 126 & 131 & 140 & 148 & 154 \\
\hline Miogo & 86 & 100.0 & 143 & 135 & 133 & 137 & 145 \\
\hline Monongalia & 79 & 100.0 & 153 & 142 & 130 & 126 & 129 \\
\hline Mooroe & 84 & 100.0 & 106 & 108 & 111 & 112 & 111 \\
\hline Morgan & 25 & 100.0 & 132 & 163 & 176 & 164 & 145 \\
\hline Nicholas & 69 & 100.0 & 111 & 116 & 125 & 133 & 138 \\
\hline Ohio & 106 & 100.0 & 113 & 114 & 116 & 120 & 124 \\
\hline Pendleton & 104 & 100.0 & 100 & 105 & 111 & 107 & 109 \\
\hline Pleasants & 68 & 100.0 & 162 & 163 & 127 & 123 & 143 \\
\hline Pocahootas & 89 & 100.0 & 94 & 93 & 92 & 95 & 95 \\
\hline Preston & 79 & 100.0 & 110 & 112 & 114 & 115 & 117 \\
\hline Patoam & 80 & 100.0 & 145 & 127 & 135 & 140 & 148 \\
\hline Raleigh & 73 & 100.0 & 122 & 118 & 121 & 126 & 130 \\
\hline Randolph & 79 & 100.0 & 116 & 105 & 107 & 109 & 110 \\
\hline Ritchie & 103 & 100.0 & 95 & 94 & 94 & 98 & 100 \\
\hline Roane & 76 & 100.0 & 83 & 85 & 88 & 89 & 90 \\
\hline Summers & 108 & 100.0 & 120 & 114 & 117 & 121 & 120 \\
\hline Taylor & 91 & 100.0 & 106 & 107 & 109 & 113 & 114 \\
\hline Tucker & 118 & 100.0 & 94 & 97 & 99 & 101 & 99 \\
\hline Tyler & 85 & 100.0 & 98 & 103 & 105 & 108 & 113 \\
\hline Upshur & 89 & 100.0 & $1 I I$ & 128 & 159 & 171 & 164 \\
\hline Wayne & 103. & 100.0 & 141 & 149 & 162 & 165 & 172 \\
\hline Webster & 100 & 100,0 & 151 & 142 & 129 & 126 & 125 \\
\hline Wetzel & 101 & 100.0 & 124 & 125 & 135 & 176 & 191 \\
\hline Wirt & 83 & 100.0 & 86 & 85 & 98 & 101 & 104 \\
\hline Wood & 87 & 100.0 & 125 & 166 & 193 & & 199 \\
\hline Wyoming & 77 & 100.0 & 129 & 128 & 138 & 149 & 181 \\
\hline TOTAL & 86 & 100.0 & 128 & 128 & 132 & 136 & 141 \\
\hline
\end{tabular}


TABLE 2A. A COMPARISON OF THE TOTALEXPENDITURES FOR PUBLIC SCHOOL EDUCATION IN THE COUNTIES OF WEST VIRGINIA AND THE TOTAL PERSONAL INCOME: EXPENDITURES ARE GIVEN AS A PERCENTAGE OF TOTAL PERSONAL INCOME

Data for this table were obtained by dividing the data in Table 1B of this section by the data of Table $1 B$ of Section VIII and multiplying by 100 .

The educational "enterprise" in many West Virginia connties is the greatest single enterprise of the connty, employing the largest number of people and making the largest expenditures.

\begin{tabular}{|c|c|c|c|c|c|c|c|}
\hline COUNTY & 1940 & 1950 & 1955 & 1956 & 1957 & 1958 & 1959 \\
\hline Barbour & 7.09 & 3.56 & 3.53 & 3.45 & 3.53 & 3.72 & 3.56 \\
\hline Berkeley & 4.02 & 2.23 & 2.79 & 2.76 & 2.99 & 2.54 & 2.37 \\
\hline Boone & 6.48 & 3.51 & 4.18 & 4.08 & 4.11 & 4.83 & 4.81 \\
\hline Braxton & 9.99 & 4.50 & 4.38 & 4.28 & 4.23 & 4.22 & 4.39 \\
\hline Brooke & 5.50 & 2.44 & 3.24 & 3.11 & 3.02 & 3.09 & 3.15 \\
\hline Cahell & 5.34 & 2.81 & 2.71 & 2.56 & 2.55 & 2.81 & 2.90 \\
\hline Calhouo & 10,96 & 7.08 & 6.30 & 5.48 & 5.54 & 5.87 & 5.75 \\
\hline Clay & 7.67 & 4.41 & 4.62 & 4.66 & 4.81 & 5.34 & 5.73 \\
\hline Doddridge & 12.39 & 5.95 & 6.19 & 6.09 & 6.17 & 5.91 & 5.88 \\
\hline Fayette & 4.70 & 3.14 & 3.85 & 3.40 & 3.62 & 4.04 & 4.14 \\
\hline Gilmer & 10.66 & 5.91 & 6.23 & 7.22 & 6.89 & 6.39 & 4.93 \\
\hline Grant & 8.22 & 3.49 & 3.12 & 3.03 & 3.04 & 3.13 & 2.97 \\
\hline Greenbrier & 6.81 & 3.56 & 3.46 & 3.28 & 3.30 & 3.66 & 3.80 \\
\hline Hampshire & 7.40 & 3.56 & 3.60 & 3.77 & 3.56 & 3.88 & 3.57 \\
\hline Hagcock & 3.76 & 2.00 & 2.42 & 2.32 & 2.36 & 2.73 & 2.95 \\
\hline Hardy & 8.14 & 3.20 & 3.40 & 3.51 & 3.24 & 3.42 & 3.36 \\
\hline Harrisoa & 4.88 & 2.24 & 2.33 & 2.27 & 2.30 & 2.63 & 2.85 \\
\hline Jackson & 8.96 & 4.98 & 3.22 & 2.35 & 1.36 & 2.33 & 2.27 \\
\hline Jeffersoo & 5.39 & 3.31 & 3.26 & 3.81 & 4.80 & 4.98 & 3.83 \\
\hline Kanawha & 5.21 & 2.59 & 3.58 & 3.03 & 2.70 & 2.95 & 3.11 \\
\hline Lewis & 7.54 & 3.76 & 4.14 & 4.21 & 4.76 & 4.63 & 4.68 \\
\hline Liocolo & 11.94 & 5.93 & 6.73 & 5.94 & 5.96 & 6.55 & 6.71 \\
\hline Logan & 4.68 & 2.58 & 4.94 & 3.76 & 3.76 & 4.28 & 4.45 \\
\hline McDowell & 4.47 & 3.09 & 4.02 & 4.08 & 4.30 & 5.29 & 5.85 \\
\hline Marion & 4.47 & 2.54 & 2.63 & 2.50 & 2.50 & 2.69 & 2.85 \\
\hline Marshall & 4.68 & 2.01 & 2.66 & 2.64 & 2.62 & 2.16 & 2.35 \\
\hline Masoa & 8.66 & 3.19 & 4.54 & 3.26 & 3.13 & 3.21 & 3.02 \\
\hline Mercer & 4.89 & 3.14 & 4.03 & 4.52 & 4.48 & 4.39 & 3.88 \\
\hline Mineral & 6.05 & 4.44 & 4.38 & 4.54 & 4.78 & 4.82 & 3.94 \\
\hline Mingo & 8.37 & 3.63 & 4.71 & 4.47 & 4.65 & 5.40 & 5.99 \\
\hline Monoogalia & 5.08 & 2.91 & 3.99 & 3.58 & 3.09 & 3.17 & 3.19 \\
\hline Manroe & 9.79 & 4.30 & 4.48 & 4.18 & 4.28 & 4.13 & 4.41 \\
\hline Morgan & 6.83 & 3.40 & 3.83 & 4.49 & 4.76 & 4.55 & 3.77 \\
\hline Nicholas & 8.30 & 3.72 & 3.65 & 3.53 & 3.63 & 4.38 & 4.50 \\
\hline Obio & 3.73 & 1.83 & 1.85 & 1.72 & 1.70 & 1.84 & 1.84 \\
\hline Pendletoa & 11.85 & 5.75 & 4.67 & 4.69 & 4.74 & 4.56 & 3.99 \\
\hline Pleasants & 6.75 & 5.08 & 6.60 & 6.17 & 4.32 & 4.16 & 4.87 \\
\hline Pocahontas & 7.64 & 4.74 & 4.14 & 3.76 & 3.56 & 4.11 & 3.79 \\
\hline Preston & 9.24 & 4.40 & 5.53 & 5.31 & 4.96 & 5.47 & 5.49 \\
\hline Putoam & 7.08 & 4.32 & 4.78 & 3.61 & 3.50 & 3.81 & 3.43 \\
\hline Raleigh & 4.48 & 3.43 & 4.21 & 3.49 & 3,41 & 3.87 & 4.21 \\
\hline Randolpb & 7.69 & 4.76 & 5.24 & 4.49 & 4.32 & 4.47 & 4.30 \\
\hline Ritchie & 9.97 & 5.02 & 4.36 & 4.26 & 4.01 & 4.33 & 4.40 \\
\hline Roace & 8.92 & 5.66 & 4.08 & 4.04 & 3.84 & 3,90 & 3.83 \\
\hline Summers & 8.59 & 3.92 & 4.71 & 4.43 & 4.26 & 4.71 & 4.50 \\
\hline Taylor & 5.76 & 3.54 & 3.52 & 3.27 & 3.28 & 3.74 & 3.81 \\
\hline Tucker & 9.73 & 4.84 & 4.73 & 4.80 & 4.70 & 4.89 & 4.71 \\
\hline Tyler & 7.90 & 5.34 & 4.65 & 4.53 & 4.70 & 4.45 & 4.90 \\
\hline Upshur & 9.94 & 4.01 & 4.24 & 4.61 & 5.42 & 6.21 & 5.91 \\
\hline Wayoe & 12,18 & 4.45 & 5.08 & 5.14 & 5.41 & 5.77 & 5.74 \\
\hline Webster & 8.28 & 3.40 & 5.80 & 5.16 & 4.55 & 4.86 & 4.87 \\
\hline Wetzel & 7.94 & 3.44 & 3.64 & 3.38 & 3.45 & 4.37 & 4.64 \\
\hline Wirt & 10.12 & 6.21 & 4.89 & 4.45 & 4.72 & 4.85 & 5.38 \\
\hline Wood & 4.14 & 2.15 & 2.27 & 2.70 & 2.99 & 3.12 & 3.01 \\
\hline Wyoming & $7: 51$ & 4.47 & 4.95 & 4.37 & 4.45 & 5.51 & 6.80 \\
\hline TOTAL & 5.70 & 3.08 & 3.59 & 3.35 & 3.29 & 3.58 & 3.63 \\
\hline
\end{tabular}

Section IV EDUCATION

W. Va. Univ.

Agr. Exp. Sta Bul. Na. 464

Page 47 
TABLE 2B. INDEX OF COMPARISON BETWEEN TOTAL EXPENDITURES FOR PUBLIC SCHOOL EDUCATION IN THE COUNTIES OF WEST

VIRGINIA AND TOTAL PERSONAL INCOME IN

THE COUNTIES OF WEST VIRGINIA, $1950=100$

These data are based on the preceding table, Table $1 \mathrm{~B}$,

Section IV.

Section IV

EDUCATION
W. Va. Univ.

Agr. Exp. Sto. Bul. No. 464

Page 48

\begin{tabular}{|c|c|c|c|c|c|c|c|}
\hline COUNTY & 1940 & 1950 & 1955 & 1956 & 1957 & 1958 & 1959 \\
\hline Basbour & 199.2 & 100.0 & 99.2 & 96.9 & 99.2 & 104.5 & 100.0 \\
\hline Berkeley & 180.3 & 100.0 & 125.1 & 123.8 & 134.1 & 113.9 & 106,3 \\
\hline Boone & 184.6 & 100.0 & 119.1 & 116.2 & 117.1 & 137.6 & 137.0 \\
\hline Braxton & 222.0 & 100.0 & 97.3 & 95.1 & 94.0 & 93.8 & 97.6 \\
\hline Brooke & 225.4 & 100.0 & 132.8 & 127.5 & 123.8 & 126.6 & 129.1 \\
\hline Cahell & 190.0 & 100.0 & 96.4 & 91.1 & 90.7 & 100,0 & 103.2 \\
\hline Calhoun & 154.8 & 100,0 & 82.0 & 77.4 & 78.2 & 82.9 & 81.2 \\
\hline Clay & 173.9 & 100.0 & 104.8 & 105.7 & 102.1 & 121.1 & 129.9 \\
\hline Doddridge & 208.2 & 100.0 & 104.0 & 102.4 & 103.7 & 99.3 & 98,8 \\
\hline Fayette & 149.7 & 100.0 & 122.6 & 108,3 & 115.3 & 128.7 & 131.8 \\
\hline Gilmer & 180.4 & 100.0 & 105.4 & 122.2 & 116.6 & 108.1 & 83.4 \\
\hline Grant & 235.5 & 100.0 & 89.4 & 86.8 & 87.1 & 89.7 & 85.1 \\
\hline Greea hrier & 191.3 & 100.0 & 97.2 & 92.1 & 92.7 & 102.8 & 106.7 \\
\hline Hampshire & 207.9 & 100,0 & 101,1 & 105.9 & 100.0 & 109,0 & 100.3 \\
\hline Hancock & 188.0 & 100.0 & 121.0 & 116.0 & 118,0 & 136.5 & 147.5 \\
\hline Hardy & 254.4 & 100.0 & 106,2 & 109.7 & 101.2 & 106.9 & 105.0 \\
\hline Marrison & 217.9 & 100.0 & 104.0 & 101.3 & 102.7 & 117.4 & 127.2 \\
\hline Jackson & 179.9 & 100.0 & 64.7 & 47.2 & 27.3 & 46.8 & 45.6 \\
\hline Jefferson & 162.8 & 100.0 & 98.5 & 115.1 & 145.0 & 150.5 & 115.7 \\
\hline Kanawha & 201.2 & 100.0 & 138.2 & 117.0 & 104.2 & 113.9 & 120.1 \\
\hline Lewis & 200.5 & 100.0 & 110.1 & 112.0 & 126.6 & 123.1 & 124.5 \\
\hline Lincoln & 201.3 & 100.0 & 113.5 & 100.2 & 100.5 & 110.5 & 113.2 \\
\hline Logan & 181.4 & 100.0 & 191.5 & 145,7 & 145.7 & 165.9 & 172,5 \\
\hline McDawell & 144.7 & 100,0 & 130.1 & 132.0 & 139.2 & 171.2 & 189.3 \\
\hline Marion & 176,0 & 100.0 & 103.5 & 98.4 & 98.4 & 105.9 & 112.2 \\
\hline Marshall & 232.8 & 100.0 & 132.3 & 131.3 & 130.3 & 107.5 & 116.9 \\
\hline Mason & 271.5 & 100.0 & 142.3 & 102.2 & 98.1 & 100.6 & 94.7 \\
\hline Mercer & 155.7 & 100.0 & 128.3 & 143.9 & 142.7 & 139.8 & 123.6 \\
\hline Mineral & 136.3 & 100.0 & 98.6 & 102.3 & 107.7 & 108.6 & 88.7 \\
\hline Mingo & 230.6 & 100.0 & 129.8 & 123.1 & 128.1 & 148.8 & 165.0 \\
\hline Mannngalia & 174.6 & 100.0 & 137.1 & 123.0 & 106.2 & 108.9 & 109.6 \\
\hline Mooroe & 227.7 & 100.0 & 104.2 & 97.2 & 99.5 & 96.0 & 102.6 \\
\hline Morgan & 200.9 & 100.0 & 112.6 & 132.1 & 140.0 & 133.8 & 110.9 \\
\hline Nicholas & 223.1 & 100.0 & 98.1 & 94.9 & 97.6 & 117.7 & 121.0 \\
\hline Ohio & 203.8 & 100.0 & 101.1 & 94.0 & 92.9 & 100.5 & 100.5 \\
\hline Pendlecon & 206.1 & 100.0 & 81.2 & 81.6 & 82.4 & 79.3 & 69.4 \\
\hline Pleasants & 132.9 & 100,0 & 129.9 & 121.5 & 85.0 & 81.9 & 95.9 \\
\hline Pocahontas & 161.2 & 100.0 & 87.3 & 79.3 & 75.1 & 86.7 & 80.0 \\
\hline Preston & 210.0 & 100.0 & 125.7 & 120.7 & 112.7 & 124.3 & 124.8 \\
\hline Patoam & 163.9 & 100.0 & 110.6 & 83.6 & 81.0 & 88.2 & 79.4 \\
\hline Raleigh & 130.6 & 100.0 & 122.7 & 101.7 & 99.4 & 112.8 & 122.7 \\
\hline RandoIph & 161.6 & 100.0 & 110.1 & 94.3 & 90.8 & 93.9 & 90.3 \\
\hline Ritchie & 198.6 & 100.0 & 86.9 & 84.9 & 79.9 & 86.3 & 87.6 \\
\hline Roane & 157.6 & 100.0 & 72.1 & 71.4 & 67.8 & 68.9 & 67.7 \\
\hline Summers & 219.1 & 100.0 & 120.2 & 113.0 & 108.7 & 120,2 & 114.8 \\
\hline Taylot & 162.7 & 100.0 & 99.4 & 92.4 & 92.7 & 105.6 & 107.6 \\
\hline Tucket & 201.0 & 100,0 & 97.7 & 99.2 & 97.1 & 101.0 & 97.3 \\
\hline Tyler & 147.9 & 100.0 & 87.1 & 84.8 & 88.0 & 83.3 & 91.8 \\
\hline Upshur & 247.9 & 100.0 & 105.7 & 115.0 & 135.2 & 154.9 & 147.4 \\
\hline Wayne & 273.7 & 100.0 & 114.2 & 115.5 & 121.6 & 129.7 & 129.0 \\
\hline Wehster & 243.5 & 100.0 & 170.6 & 151.8 & 133.8 & 142.9 & 143,2 \\
\hline Wetzel & 230.8 & 100,0 & 105.8 & 98.3 & 100.3 & 127.0 & 134.9 \\
\hline Wirt & 163.0 & 100.0 & 78.7 & 71.7 & 76.0 & 78.1 & 86.6 \\
\hline Wood & & 100.0 & $105-6$ & 125.6 & 139.1 & 145,1 & 140.0 \\
\hline Wyoming & 168.0 & 100.0 & 110.7 & 97.8 & 99.6 & 123.3 & 152.1 \\
\hline TOTAL & 185,1 & 100.0 & 116.6 & 108.8 & 106.8 & 116.2 & 117.9 \\
\hline
\end{tabular}


TABEL 3A. THE EXPENDITURES (IN THOUSANDS OF DOLLARS) FOR INSTRUCTIONAL PURPOSES IN THE PUBLIC SCHOOLS OF THE COUNTIES OF WEST VIRGINIA

The information presented in this table was taken from the annual reports of the State Superintendent of Free Schools.

\begin{tabular}{|c|c|c|c|c|c|c|c|}
\hline COUN'TY & 1940 & 1950 & 1955 & 1957 & 1958 & 1959 & 1960 \\
\hline Barbour & 206.4 & 397.2 & 511.2 & 578.8 & 565.2 & 54.1 & 548.1 \\
\hline Berkeley & 241.5 & 521.7 & 699.2 & 900.3 & 898.5 & 962.0 & 1000.5 \\
\hline Boone & 272.4 & 591.3 & 843.8 & 1001.7 & 1065.8 & 1115.2 & 1109.3 \\
\hline Brarton & 235.5 & 418.1 & 503.1 & 577.0 & 582.4 & 593.6 & 618.6 \\
\hline Brooke & 279.6 & 548.7 & 675.8 & 843.9 & 852.8 & 851.2 & 986.0 \\
\hline Cabell & 983.5 & 2000.3 & 2641.0 & 3136.7 & 3247.4 & 3489.4 & 4086.7 \\
\hline Calhoun & 133.2 & 232.5 & 280.2 & 309.5 & 308.0 & 317.1 & 322.4 \\
\hline Clay & 153.5 & 326.4 & 417.1 & 454.3 & 477.0 & 470.7 & 160.6 \\
\hline Doddridge & 134.9 & 213.1 & 252.6 & 285.9 & 276.8 & 271.9 & 275.2 \\
\hline Fayette & 777.2 & 1685.5 & 2033.0 & 2391.1 & 2446.2 & 2553.3 & 2926.5 \\
\hline Gilmer & 142.7 & 254.9 & 289.8 & 320.4 & 312.6 & 312.7 & 317.7 \\
\hline Grant & 92.9 & 174.4 & 226.2 & 268.3 & 270.6 & 266.4 & 282.7 \\
\hline Greeobrier & 404.7 & 779.2 & 973.1 & 1098.7 & 1118.4 & 1210.7 & 1227.0 \\
\hline Hampshire & 120.4 & 236.4 & 324.4 & 372.5 & 373.8 & 391.6 & 389.5 \\
\hline Hancock & 276.8 & 636.7 & 892.4 & 1196.8 & 1304.1 & 1396.4 & 1658.4 \\
\hline Hardy & 220.4 & 229.1 & 294.9 & 331.2 & 322.9 & 335.7 & 396.5 \\
\hline Harrisoo & 771.1 & 1616.4 & 2027.0 & 2166.1 & 2275.4 & 2365.2 & 2580.4 \\
\hline Jacksoo & 172.1 & 310.5 & 400.4 & $\angle 58.8$ & 492.6 & 515.7 & 601.4 \\
\hline Jefferson & 135.8 & 351.5 & 497.4 & 593.8 & 629.3 & 649.4 & 675.3 \\
\hline Kanawha & 2072.0 & 4798.8 & 6589.8 & 7877.6 & 8288.5 & 8776.2 & 9662.2 \\
\hline Lewis & 208.2 & 397.3 & 465.1 & 527.3 & 523.7 & 519.8 & 541.1 \\
\hline Liocolo & 236.0 & 473.6 & 656.0 & $74 \mathrm{he?}$ & 744.7 & 752.0 & 800.9 \\
\hline Logan & 588.4 & 1262.6 & 1882.4 & 2159.0 & 2399.2 & 2615.3 & 2748.1 \\
\hline McDowell & 1013.3 & 1920.8 & 2514.3 & 2990.1 & 3070.4 & 3072.4 & 3432.8 \\
\hline Marion & 617.6 & 1376.6 & 1705.4 & 1917,3 & 1985.8 & 2136.5 & 2256.4 \\
\hline Marshall & 335.6 & 586.2 & 743.3 & 811.6 & 915.3 & 931.7 & 1155.9 \\
\hline Mason & 225.1 & 458.8 & 638.0 & 764.6 & 731.3 & 758.3 & 872.0 \\
\hline Mercer & 655.6 & 1514.1 & 1970.9 & 2297.5 & 2334.7 & 2380.7 & 2507.3 \\
\hline Mineral & 177.3 & 380.9 & 586.7 & 708.9 & 741.5 & 761.5 & 839.5 \\
\hline Mingo & 102.1 & 1027.4 & 1395.0 & 1640.3 & 1669.9 & 1702.9 & 1967.7 \\
\hline Monoogalia & 251.8 & 1063.0 & 1497.6 & 1736.8 & 1731.7 & 1735.4 & 2001.8 \\
\hline Mooroe & 7.5 .4 & 266.1 & 360.0 & $\angle 18.9$ & 421.4 & 413.7 & $1,17.5$ \\
\hline Morgan & 99.7 & 184.5 & 219.1 & 247.5 & 303.8 & 317.2 & 318.0 \\
\hline Nicholas & 241.7 & 555.8 & 731.2 & 819.9 & 837.5 & 872.3 & 905.2 \\
\hline Ohio & $6 ! 2,0$ & 1152.6 & 1369.1 & 1578.3 & 1667.3 & 1716.0 & 1949.6 \\
\hline Pendleton & 132.9 & 212.3 & 221.5 & 253.0 & 248.1 & 250.5 & 255.0 \\
\hline Pleasants & 68.1 & 136.9 & 177.9 & 198.6 & 240.8 & 256.2 & 299.7 \\
\hline Pocahootas & 156.8 & 273.1 & 332.8 & 363.3 & 367.9 & 352.6 & 384.8 \\
\hline Prestoo & 351.7 & 694.5 & 903.5 & 1051.9 & 1032.9 & 1059.4 & 1.1 40.0 \\
\hline Putnam & 198.0 & 394.8 & 547.9 & 697.7 & 727.4 & 782.7 & 834.3 \\
\hline Raleigh & 832.4 & 1963.9 & 2634.0 & 3006.0 & 3084.9 & 3153.5 & 3584.2 \\
\hline Raodolph & 337.4 & 684.7 & 877.2 & 1001.0 & 1001.9 & 983.0 & 100.0 \\
\hline Ritchie & 176.3 & 316.3 & 327.2 & 343.9 & 344.6 & 358.9 & 363.5 \\
\hline Roane & 211.5 & 374.9 & 448.0 & 503.6 & 487.9 & 187.9 & 519.2 \\
\hline Summers & 232.1 & 380.1 & 482 & 555.7 & 51.6 .5 & 581.9 & 589.5 \\
\hline Taylor & 171.0 & 328.2 & 394.1 & 447.1 & 450.7 & 157.9 & 156.6 \\
\hline Tucker & 162.0 & 276.4 & 306.3 & 331.0 & 318.7 & 318.3 & 319.9 \\
\hline Tyler & 125.6 & 224.6 & 271.5 & 322.6 & 313.2 & 329.7 & 383.6 \\
\hline Upshar & 205.0 & 392.2 & 509.7 & 572.0 & 585.2 & 612.0 & 625.3 \\
\hline Wayne & 366.5 & 720.0 & 1033.3 & 1218.9 & 1260.1 & 1276.9 & 1525.0 \\
\hline Webster & 195.8 & 363.4 & 468.1 & 533.9 & 524.2 & 542.0 & 537.4 \\
\hline Wetzel & 250.7 & 457.0 & 555.0 & 666.4 & 688.3 & 694.1 & 840.7 \\
\hline Wirt & 75.1 & 129.7 & 141.5 & 157.6 & 158.0 & 165.5 & 168.1 \\
\hline Food & 512.9 & 1060.2 & 1538.1 & $21,5.2$ & 2207.1 & 2232.9 & 2654.0 \\
\hline Wyoming & 337.9 & 804.0 & 1111.3 & 1337.3 & 1456.4 & 1592.5 & 1827.7 \\
\hline TOTAL & 18959.1 & $9,130.2$ & $1,386.6$ & $60,269.0$ & $62,231.3$ & $64,571.6$ & $71,151.0$ \\
\hline
\end{tabular}

Section IV EDUCATION
W. Ya. Univ. Agr. Exp. Sta. Bul. No. 464

Page 49 
TABLE 3B. THE EXPENDITURES (IN THOUSANDS OF DOLLARS ADJUSTED BY THE WHOLESALE COMMODITY INDEX) FOR INSTRUCTIONAL PURPOSES IN THE COUNTIES OF WEST VIRGINIA

The information in this table has been prepared from that in the preceding table, Table $3 \mathrm{~A}$, Section IV.

Section IV EDUCATION

W. Va. Univ, Agr. Exp. Sto. Bul. No. 464

Page 50

\begin{tabular}{|c|c|c|c|c|c|c|c|}
\hline COUNTY & 1940 & 1950 & 1955 & 1957 & 1958 & 1959 & 1960 \\
\hline Barbour & 406.3 & 403.7 & 464.3 & 498.1 & 476.2 & 455.7 & 459.0 \\
\hline Berkeley & 475.4 & 530.2 & 635.1 & 774.8 & 757.0 & 805.7 & 837.9 \\
\hline Boone & 536.2 & 600.9 & 766.4 & 862.0 & 897.9 & 934.0 & 929.1 \\
\hline Braxtoo & 1.63 .6 & 424.9 & 456.9 & 496.6 & 490.6 & 497.2 & 518.1 \\
\hline Brooke & 550.4 & 557.6 & 613.8 & 726.2 & 718.4 & 712.9 & 825.8 \\
\hline Cabell & 1936.0 & $2032 . .8$ & 2398.7 & 2699.4 & 2735.8 & 2922.4 & 3422.7 \\
\hline Calhoun & 262.2 & 236.3 & 254.5 & 266.4 & 259.5 & 265.6 & 270.0 \\
\hline Clay & 302.2 & 331.7 & 378.8 & 391.0 & 401.9 & 394.2 & 385.8 \\
\hline Doddridge & 265.6 & 216.6 & 229,4 & 246.0 & 233.2 & 227.7 & 230.5 \\
\hline Fayette & 1529.9 & 1712.9 & 1846.5 & 2057.7 & 2060.8 & $2 \pm 38.4$ & 2451.0 \\
\hline Gilmer & 280.9 & 259.0 & 263.2 & 275.7 & 263.4 & 261.9 & 266.1 \\
\hline Grant & 182.9 & 177.2 & 205.4 & 230.9 & 228.0 & 223.1 & 236.8 \\
\hline Greenbrier & 796.7 & 791.9 & 883.8 & 945.5 & 942.2 & 1014.0 & 1027.6 \\
\hline Hampshire & 237.0 & 240.2 & 294.6 & 320.6 & 314.9 & 328.0 & 326.2 \\
\hline Hancock & 544.9 & 647.1 & 810.5 & 1029.9 & 1098.7 & 1169.5 & 1388.9 \\
\hline Hardy & 237.0 & 232.8 & 267.8 & 288.2 & 272.0 & 281.2 & 332.1 \\
\hline Harrison & 1523.8 & 1642.7 & 1841,1 & 1864.1 & 1916.9 & 1980.9 & 21611 \\
\hline Jackson & 338.8 & 315.5 & 363.7 & 394.8 & 415.0 & 431.9 & 503.7 \\
\hline Jeffersno & 267.3 & 357.2 & 451.8 & 511.0 & 530.2 & 543.9 & 565.6 \\
\hline Kanawha & 4078.7 & 4876.8 & 5985.3 & 6779.3 & 6982.7 & 7350.3 & 8092.3 \\
\hline Lewis & 409.8 & 403.8 & 422.4 & 453.8 & 4412 & 435.3 & 453.2 \\
\hline Lincolo & 464.6 & 481.3 & 595.8 & 640.4 & 627.4 & 629.8 & 670.8 \\
\hline Logan & 1158.3 & 1283.1 & 1709.7 & 1858.0 & 2021.2 & 2190.4 & 2301.6 \\
\hline McDnwell & 1994.7 & 1952.0 & 2283.7 & 2573.2 & 2586.7 & 2573.2 & 2875.0 \\
\hline Marinn & 1215.7 & 1399.0 & 1549.0 & 1650.0 & 1673.0 & 1789.4 & 1889.8 \\
\hline Marshall & 660.6 & 595.7 & 675.1 & 724.3 & 771,1 & 780.3 & 968.1 \\
\hline Mason & 443.1 & 466.3 & 579.5 & 658.0 & 616.1 & 635.1 & 730.3 \\
\hline Mercer & 1290.6 & 1538.7 & 1790.1 & 1977.2 & 1966.9 & 1993.9 & 2100.0 \\
\hline Mineral & 342.0 & 387.1 & 532.9 & 610.1 & 624.7 & 637.8 & 703.1 \\
\hline Mingo & 968.7 & 1044.1 & 1267.0 & 1411.6 & 1406.8 & 1426.2 & 1648.0 \\
\hline Monongalia & 889.4 & 1080.3 & 1360,2 & 1494.7 & 1458.9 & 1453.4 & 1676.5 \\
\hline Monroe & 286.2 & 270.4 & 327.0 & 360.5 & 355.0 & 346.5 & 350.0 \\
\hline Morgao & 196.3 & 187.5 & 199.0 & 213.0 & 255.9 & 265.7 & 266.3 \\
\hline Nicholas & 475.8 & 564.8 & 664.1 & 705,6 & 705.6 & 730.6 & 758.1 \\
\hline Ohio & 1263.8 & 1171.3 & 1243.5 & 1358.3 & 1404.6 & 1437.2 & 1632.8 \\
\hline Pendletnn & .261 .6 & 215.8 & 201.2 & 217.7 & 209.0 & 209.8 & 213.6 \\
\hline Plea sants & 134.1 & 139.1 & 161.6 & 170.9 & 202.9 & 214,6 & 251.0 \\
\hline Pocahontas & 308.7 & 277.5 & 302.3 & 312.6 & 309.9 & 303.7 & 322.3 \\
\hline Preston & 692.3 & 705.8 & 820.6 & 905.2 & 870.2 & 887.3 & 954.8 \\
\hline Putnam & 389.8 & 401.2 & 497.6 & 600.4 & 612.8 & 655.5 & 698.7 \\
\hline Raleigh & 1638.6 & 1995.8 & 2392.4 & 2586.9 & 2598.9 & 2641.1 & 3001.8 \\
\hline Randolph & 664.2 & 695.8 & 796.6 & 864.0 & 844.1 & 823,3 & 840,9 \\
\hline Ritchie & 347.0 & 321.4 & 297.2 & 296.0 & 290.3 & 300.6 & 304.4 \\
\hline Roaoe & 416.3 & 381.0 & 406.9 & 433.4 & 411.0 & 408.6 & 434.8 \\
\hline Summers & 456.9 & 386.3 & 438.1 & 478.2 & 460.4 & 487.4 & 493.7 \\
\hline Taylor & 336.6 & 333.5 & 357.9 & 384.8 & 379.7 & 383.5 & 382.4 \\
\hline Tucker & 318.9 & 280.9 & 278.2 & 284.9 & 268.5 & 266.6 & 267.9 \\
\hline Tyler & 247.2 & 228.3 & 246.6 & 277.6 & 263.9 & 276.1 & 321.3 \\
\hline Upshur & 403.5 & 398.6 & 462.0 & 492.3 & 493.0 & 512.6 & 523.7 \\
\hline Wayoe & 721.5 & 731.7 & 938.5 & 1049.0 & 1061.6 & 1069.4 & 1277.2 \\
\hline Webster & 385.4 & 369.3 & 425.2 & 459.5 & 441.6 & 453.1 & 450.1 \\
\hline Wetzel & 493.5 & 464.4 & 504.1 & 573.5 & 579.9 & 581.3 & 704.1 \\
\hline Wirt & 147.8 & 131.8 & 128.5 & 135.6 & 133.1 & 138.6 & 140.8 \\
\hline Wood & 10096 & 1077.4 & 1397.0 & 1846.1 & 1859.4 & 1870.1 & 2222.8 \\
\hline Wyoming & 665.2 & 817.1 & 1009.4 & 1150.9 & 1227.0 & 1333.8 & 1530.7 \\
\hline TOTAL & 37321.1 & 39766.5 & 46672.7 & 51866.6 & 52427.4 & 54080.1 & 59590.5 \\
\hline
\end{tabular}


TABLE 3C. INDEX OF THE EXPENDITURES (ADJUSTED BY THE WHOLESALE COMMODITY INDEX) FOR INSTRUCTIONAL PURPOSES IN THE COUNTIES OF WEST VIRGINIA, $1950=100$

Data presented here are based on those in the preceding table,

Table 3B, Section IV.

\begin{tabular}{|c|c|c|c|c|c|c|c|}
\hline COUNTY & 79,0 & 1950 & 1955 & 1057 & 1958 & 1959 & 1960 \\
\hline Barbour & 100.6 & 100.0 & 715.0 & 723.4 & 178.0 & 112.9 & 113.7 \\
\hline Berkeley & 89.7 & 100.0 & 119.8 & 146.1 & 112.8 & 152.0 & 158.0 \\
\hline Boone & 89.2 & 100.0 & 127.5 & 143.5 & 119.4 & 155.4 & 154.6 \\
\hline Braxton & 109.1 & 100.0 & 107.5 & 116.9 & 115.5 & 117.0 & 121.9 \\
\hline Brooke & 98.7 & 100.0 & 170.7 & 130.2 & 128.8 & 127.9 & 148,1 \\
\hline Cabell & 95.2 & 100.0 & 118.0 & 132.8 & 134.6 & 143.8 & 168.4 \\
\hline Calhoun & 111.0 & 100.0 & 107.7 & 112.7 & 109.8 & 112.4 & 1.14 .3 \\
\hline Clay & 91.1 & 100.0 & 714.2 & 177.9 & 721.2 & 778.8 & 116.3 \\
\hline Doddridge & 122.6 & 100.0 & 105.9 & 113.6 & 107.7 & 305.1 & 106.4 \\
\hline Fayette & 89.3 & 100.0 & 107.8 & 120.1 & 120.3 & $12 L .8$ & 143.1 \\
\hline Gilmer & 108.5 & 100.0 & 101.6 & 106.4 & 107.7 & 102.1 & 102.7 \\
\hline Grant & 103.2 & 100.0 & 115.9 & 130.3 & 128.7 & 125.9 & 133.6 \\
\hline Green briet & 100.6 & 100.0 & 111.6 & 112.4 & 110.0 & 128.0 & 129.8 \\
\hline Hampshire & 98.7 & 100.0 & 122.6 & 133.5 & 131.1 & 136.6 & 135.8 \\
\hline Hancock & 84.2 & 100.0 & 125.3 & 159.2 & 169.8 & 180.7 & 214.6 \\
\hline Hardy & 101.8 & 100.0 & 115.0 & 123.8 & 116.8 & 120.8 & 142.7 \\
\hline Harrison & 92.8 & 100.0 & 112.1 & 113.5 & 116.7 & 120.6 & 131.6 \\
\hline Jackson & 107.4 & 100.0 & 115.3 & 125.1 & 131.5 & 136.9 & 159.7 \\
\hline Jefferson & 74.8 & 100.0 & 126.5 & 143.1 & 148.4 & 152.3 & 158.3 \\
\hline Kanawha & 83.6 & 100.0 & 122.7 & 139.0 & I/ $3=2$ & 150.7 & 165.9 \\
\hline Lewis & 101.5 & 100.0 & 104.6 & 112.4 & 109.3 & 107.8 & 112.2 \\
\hline Lincolo & 96.5 & 100.0 & 123.8 & 133.1 & 130.4 & 130.9 & 139.4 \\
\hline Logac & 90.3 & 100.0 & 133.2 & 144.8 & 157.5 & 170.7 & 179.4 \\
\hline MeDowell & 102.2 & 100.0 & 117.0 & 131.8 & 132.5 & 131.8 & 147.3 \\
\hline Marion & 86.9 & 100.0 & 110.7 & 117.9 & 119.6 & 127.9 & 135.1 \\
\hline Marshall & 110.9 & 100.0 & 113.3 & 121.6 & 129.4 & 131.0 & 162.5 \\
\hline Mason & 95.0 & 100.0 & 124.3 & 141.1 & 132.1 & 136.2 & 156.6 \\
\hline Metcer & 83.9 & 100.0 & 116.3 & 128.5 & 127.8 & 129.6 & 136.5 \\
\hline Mineral & 90.2 & 100.0 & 137.7 & 157.6 & 151.4 & 164.8 & 181.6 \\
\hline Mingo & 92.8 & 100.0 & 121.3 & 135.2 & 134.7 & 136.6 & 157.8 \\
\hline Moooogalia & 82.3 & 100.0 & 125.9 & 138.4 & 135.0 & 134.5 & 155.2 \\
\hline Monroe & 105.8 & 100.0 & 120.9 & 133.3 & 131.3 & 128.1 & 129.4 \\
\hline Morgan & 104.7 & 100.0 & 106.1 & 113.6 & 136.5 & 141.7 & 142.0 \\
\hline Nicholas & 84.2 & 100.0 & 117.6 & 124.9 & 124.9 & 129.4 & 134.2 \\
\hline Ohio & 107.9 & 100.0 & 106.2 & 116.0 & 119.9 & 122.7 & 139.4 \\
\hline Pendleroa & 121.2 & 100.0 & 93.2 & 100.9 & 96.8 & 97.2 & 99.0 \\
\hline Pleasants & 96.4 & 100.0 & 116.2 & 122.9 & 145.9 & $1 5 \longdiv { 4 . 3 }$ & 180.4 \\
\hline Pocahontas & 111.2 & 100.0 & 108.9 & 112.6 & 111.7 & 109.4 & 116.1 \\
\hline Preston & 98.1 & 100.0 & 116.3 & 128.3 & 123.3 & 125.7 & 135.3 \\
\hline Putnam & 97.2 & 100.0 & 124.0 & 149.7 & 152.7 & 163.4 & 174.2 \\
\hline Raleigh & 82.1 & 100.0 & 119.9 & 129.6 & 130.2 & 132.3 & 150.4 \\
\hline Randolph & 95.5 & 100.0 & 114.5 & 124.2 & 121.3 & 118.3 & 120.9 \\
\hline Ritebie & 108.0 & 100.0 & 92.5 & 92.1 & 90.3 & 93.5 & 94.7 \\
\hline Rosce & 109.3 & 100.0 & 106.8 & 113.8 & 107.9 & 107.2 & 114.1 \\
\hline Summers & 118.3 & 100.0 & 113.4 & 123.8 & 119.2 & 126.2 & 127.8 \\
\hline Taylor & 100.9 & 100.0 & 107.3 & 115.4 & 113.9 & 175.0 & 111.7 \\
\hline Tucker & 113.5 & 100,0 & 99.0 & 101.4 & 95.6 & 94.9 & 95.4 \\
\hline Tyler & 108.3 & 100.0 & 108.0 & 121.6 & 115.6 & 120.9 & 140.7 \\
\hline Upshur & 101.2 & 100.0 & 115.9 & 123.5 & 123.7 & 128.6 & 131.4 \\
\hline Wayoe & 98.6 & 100,0 & 128.3 & 143.4 & 145.1 & 146.2 & 174.6 \\
\hline Webster & 104.4 & 100.0 & 115.1 & 124.4 & 119.6 & 122.7 & 121.9 \\
\hline Werzel & 106.3 & 100.0 & 108.5 & 123.5 & 124.9 & 125.2 & 151.6 \\
\hline Wirt & 112.1 & 100.0 & 97.5 & 102.9 & 101.0 & 105.2 & 106.8 \\
\hline Food & 93.7 & 100.0 & 129.7 & 171.3 & 172.6 & 173.6 & 206.3 \\
\hline Wyoming & 81.4 & 100.0 & 123.5 & 140.9 & 150.2 & 163.2 & 187.3 \\
\hline TOTAL & 93.8 & 100.0 & 117.4 & 130.4 & 131.8 & 136.0 & 149.9 \\
\hline
\end{tabular}

Section IV EDUCATION
W. Vo. Univ. Agr. Exp. Sto. Bul. No. 464

Page 51 
Data presented in this table are taken from the annual reports of the Superintendent of Free Schools. Annual changes in Average Daily Attendance may come from several sources - first, the migration of children of $\mathrm{school}$ age; second, from the increased length of the school year; third, from changes in the beginning age; and fourth, from an increase in the size of the entering age group compared with the terminal age group based on variation in the birth rate.

Section IV EDUCATION
W. Va. Univ.

Agr. Exp. Sta,

Bul. Na. 464

Page 52

\begin{tabular}{|c|c|c|c|c|c|c|c|}
\hline COUNTY & 1940 & 1950 & 1955 & 1957 & 1958 & 1959 & 1960 \\
\hline Barbour & 4252 & 1,157 & 3995 & 3737 & 3675 & 3602 & 3510 \\
\hline Berkeley & 5242 & 4805 & 5521 & 5858 & 5862 & 6101 & 6232 \\
\hline Bonne & 7052 & 7449 & 8345 & 8376 & 8409 & 8455 & 8147 \\
\hline Braxton & 4980 & 4179 & 3963 & 3838 & 3715 & 3837 & 3793 \\
\hline Bronke & 5349 & 4513 & 5007 & 5104 & 5169 & 5236 & 5382 \\
\hline Cabell & 18014 & 17424 & 19020 & 19504 & 19491 & 20201 & 20012 \\
\hline Calhoun & 2778 & 2327 & 2094 & 1977 & 1933 & 1951 & 1952 \\
\hline Clay & 3568 & 3571 & 3727 & 3611 & 3567 & 3697 & 3578 \\
\hline Doddridge & 2434 & 1933 & 1774 & 1649 & 1575 & 1579 & 1574 \\
\hline Fayette & 19223 & 19373 & 18592 & 18091 & 17980 & 18031 & 17382 \\
\hline Gilmer & 2754 & 2131 & 1961 & 1839 & 1756 & 1831 & 1787 \\
\hline Grant & 1764 & 1862 & 1922 & 1972 & 1938 & 1967 & 1952 \\
\hline Greeohriet & 9103 & 8602 & 8568 & 8544 & 8446 & 8684 & 8453 \\
\hline Hampshire & 2601 & 2426 & 2562 & 2582 & 2518 & 2566 & 2552 \\
\hline Hancock & 6177 & 5811 & 6615 & 6867 & 6965 & 7163 & 7355 \\
\hline Hardy & 2313 & 2041 & 2099 & 2121 & 2096 & 2142 & 2138 \\
\hline Harrison & 17302 & 15353 & 15579 & 15439 & 15334 & 15505 & 15452 \\
\hline Jackson & 3520 & 3193 & 3200 & 3358 & 3630 & 3877 & 4216 \\
\hline Jeffersoo & 3282 & 3360 & 3696 & 3894 & 3904 & 3985 & $\lcm{1019}$ \\
\hline Kanawha & 40606 & 45646 & 51424 & 53301 & 53985 & 55647 & 55626 \\
\hline Lewis & 3958 & 3352 & 3257 & 3216 & 3191 & 3280 & 3291. \\
\hline Lincoln & 5336 & 5469 & 5624 & 5473 & 5509 & 5776 & 5298 \\
\hline Logaa & 15694 & 16158 & 17034 & 17946 & 17922 & 18136 & 17580 \\
\hline McDowell & 22950 & 22945 & 22475 & 21923 & 2114,6 & 21308 & 204,36 \\
\hline Marion & 11430 & 12968 & 12834 & 12848 & 12751 & 13029 & 12790 \\
\hline Marshall & 7262 & 5683 & 6141 & 6347 & 6513 & 6606 & 6647 \\
\hline Mason & 4680 & 4724 & 5100 & 4960 & 4979 & 5228 & 5339 \\
\hline Mercer & 15374 & 15551 & 16016 & 16210 & 16159 & 16407 & 16076 \\
\hline Mineral & 4376 & 4604 & 1911 & 4901 & 4858 & 4935 & 4876 \\
\hline Mingo & 11295 & 12218 & 13387 & 13454 & 13000 & 13006 & 72675 \\
\hline Monongalia & 10565 & 9976 & 30257 & 10452 & 10461 & 10639 & 10442 \\
\hline Montbe & 2808 & 2619 & 2789 & $27 / 17$ & 2710 & 2725 & 2696 \\
\hline Morgan & 1937 & 1765 & 1795 & 1807 & 1843 & 1828 & 1866 \\
\hline Nichnlas & 5645 & 6453 & 6693 & 6889 & 6904 & 7029 & 6806 \\
\hline Obio & 11100 & 8248 & 8418 & 8712 & 8737 & 8837 & 8899 \\
\hline Pendleron & 2532 & 2006 & 1921 & 1869 & 1809 & 1829 & 1827 \\
\hline Pleasaots & 1537 & 1196 & 1358 & 1449 & 1494 & 1537 & 1575 \\
\hline Pocahoutas & 3302 & 2802 & 2626 & 2472 & $24 \mathrm{IL}_{4}$ & 2450 & 2368 \\
\hline Prestoo & 6976 & 6736 & 6923 & 6731 & 6650 & 6769 & 6622 \\
\hline Potoam & 4432 & 4347 & 5116 & 5337 & 5401 & 5590 & 5660 \\
\hline Raleigh & 21365 & 21947 & 21379 & $216 / 1$ & 21849 & 21832 & 20548 \\
\hline Randolph & 6716 & 6722 & 6481 & 621,8 & 6063 & 6126 & 5982 \\
\hline Ritchie & 3409 & 2507 & 2389 & 2378 & 2308 & 2346 & 2313 \\
\hline Rpace & 4592 & 3513 & 3670 & 3576 & 3438 & 3582 & 3446 \\
\hline Summers & 4445 & 3898 & 3561. & 3527 & 3484 & 3606 & 3501 \\
\hline Taylor & $L 079$ & 3352 & 3285 & 3203 & 3207 & 3212 & 3066 \\
\hline Tucker & 3166 & 2527 & 2095 & 1925 & 1836 & 1850 & 1803 \\
\hline Tyler & 2595 & 1923 & 2017 & 2034 & 2021 & 2124 & 2082 \\
\hline Upshur & 4774 & 3883 & 3974 & 3971 & 3949 & 4098 & 2094 \\
\hline Wayne & 8835 & 8635 & 9275 & 9238 & 9230 & 9377 & 9311 \\
\hline Wehster & 4289 & 4207 & 4133 & 1,011 & 3846 & 3986 & 3730 \\
\hline Vetzel & 5344 & 4090 & 4086 & 1106 & 4237 & 4293 & $\lcm{2416}$ \\
\hline Wirt & 1444 & 1183 & 1121 & 1058 & 1028 & 1024 & 1000 \\
\hline Wood & $1114 ?$ & 11580 & 13038 & 13936 & 14474 & 15094 & 15540 \\
\hline Wyoming & 7524 & 8970 & 10446 & 11012 & 10983 & 10992 & 10760 \\
\hline TOTAL & 411627 & 398913 & 415289 & 419189. & 418692 & 426537 & 420503 \\
\hline
\end{tabular}


TABLE 4B. INDEX OF THE AVERAGE DAILY ATTENDANCE IN THE PUBLIC SCHOOLS IN THE COUNTIES OF WEST VIRGINIA, $1950=100$

The data presented here are based on those presented in the preceding table, Table $4 \mathrm{~A}$, Section IV.

\begin{tabular}{|c|c|c|c|c|c|c|c|}
\hline COUNTY & 1940 & 1950 & 1955 & 1957 & 1958 & 1959 & 1960 \\
\hline Barbour & 102.3 & 100.0 & 96.1 & 89.9 & 87.0 & 86.6 & 85.2 \\
\hline Berkeley & 109.1 & 100.0 & 104.9 & 121.9 & 122.0 & 127.0 & 129.7 \\
\hline Boone & 94.7 & 100.0 & 112.0 & 112.4 & 112.9 & 113.5 & 109.4 \\
\hline Braxton & 119.2 & 100.0 & 94.8 & 91.8 & 88.9 & 91.8 & 90.8 \\
\hline Brooke & 118.5 & 100.0 & 110.9 & 113.1 & 114.5 & 116.0 & 119.3 \\
\hline Cabell & 103.4 & 100.0 & 109.2 & 111.9 & 111.9 & 115.9 & 114.9 \\
\hline Calhoun & 119.4 & 100.0 & 90.0 & 85.0 & 83.1 & 83.8 & 83.9 \\
\hline Clay & 99,9 & 100.0 & 104.4 & 101.1 & 99.9 & 103.5 & 100,2 \\
\hline Doddridge & 125.9 & 100.0 & 91.8 & 85.3 & 81.5 & 81.7 & 81.4 \\
\hline Fayetie & 99.2 & 100.0 & 96.0 & 93.4 & 92.8 & 93.1 & 89.7 \\
\hline Gilmer & 129.2 & 100.0 & 92,0 & 86.3 & 82.4 & 85.9 & 83.9 \\
\hline Grant & 94.7 & 100,0 & 103.2 & 105.9 & 104.1 & 105.3 & 104.8 \\
\hline Greenbrier & 105.8 & 100.0 & 99.6 & 99.3 & 98.2 & 101.0 & 98.3 \\
\hline Hampshire & 107.2 & 100.0 & 105.6 & 106.4 & 103.8 & 105.8 & 105.2 \\
\hline Haocock & 106.3 & 100.0 & 113.8 & 118.2 & 119.9 & 123.3 & 126.6 \\
\hline Hardy & 113.3 & 100.0 & 102.8 & 103.9 & 102.7 & 104,9 & 104.8 \\
\hline Harrison & 112.7 & 100.0 & 101.5 & 100.6 & 99.9 & 101.0 & 100.6 \\
\hline Jackson & 110.2 & 100.0 & 100.2 & 105.2 & 113.7 & 121.4 & 132.0 \\
\hline Jeffersoo & 97.7 & 100.0 & 110.0 & 115.9 & 116.2 & 118.6 & 119.6 \\
\hline Kanawha & 89.0 & 100.0 & 112.7 & 116.8 & 118.3 & 121.9 & 121.9 \\
\hline Lewis & 118.1 & 100.0 & 97.2 & 95.9 & 95.2 & 97.9 & 98.2 \\
\hline Lincolo & 97.6 & 100.0 & 102.8 & 100.1 & 100.7 & 105.6 & 96.9 \\
\hline Logaa & 97.2 & 100,0 & 105.4 & 111.1 & 111.4 & 112.2 & 108.8 \\
\hline McDowell & 100.0 & 100.0 & 98.0 & 95.5 & 93.5 & 92.9 & 89.1 \\
\hline Marioo & 111.3 & 100.0 & 92.0 & 99.1 & 98.3 & 100.5 & 98.6 \\
\hline Marshall & 127.8 & 100.0 & 108.1 & 14.7 & 215.2 & 116.2 & 117.0 \\
\hline Mason & 99.1 & 100.0 & 108.0 & 105.0 & 105.4 & 110.7 & 113.0 \\
\hline Mercer & 98.9 & 100.0 & 103.0 & 104.2 & 103.9 & 105.5 & 103.4 \\
\hline Mineral & 95.0 & 100.0 & 106.7 & 106.4 & 105.5 & 107.2 & 105.9 \\
\hline Miogo & 92.4 & 100.0 & 109.6 & 110.1 & 106.4 & 106.4 & 103.7 \\
\hline Monongalia & 105.9 & 100.0 & 102.8 & 104.8 & 104.9 & 106.6 & 104.7 \\
\hline Mooroe & 107.2 & 100.0 & 106.5 & 104.9 & 103.5 & 104,0 & 102.9 \\
\hline Morgan & 109.7 & 100.0 & 101.7 & 102.4 & 104.4 & 103.6 & 105.7 \\
\hline Nicholas & 87.5 & 100.0 & 103.7 & 106.8 & 107.0 & 108.9 & 105.5 \\
\hline Ohio & 134.6 & 100.0 & 102.1 & 106.0 & 105.9 & 107.1 & 107.9 \\
\hline Peodleton & 126.2 & 100.0 & 95.8 & 93.2 & 90.2 & 91.2 & 91.1 \\
\hline Pleasants & 128.5 & 100.0 & 113.5 & 121.2 & 124.9 & 128.5 & 131.7 \\
\hline Pocahoatas & 117.8 & 100.0 & 93.7 & 88.2 & 86.2 & 87.4 & 84.5 \\
\hline Prestoo & 103.6 & 100.0 & 102.8 & 99.9 & 98.7 & 100.5 & 98.3 \\
\hline Putnam & 102.0 & 100.0 & 117.7 & 122.8 & 124.2 & 128,6 & 130.2 \\
\hline Raleigh & 97.3 & 100.0 & 97.4 & 98.6 & 99.6 & 99.5 & 93.6 \\
\hline Randolpb & 99.9 & 100.0 & 96.4 & 92.9 & 90.2 & 91.1 & 89.0 \\
\hline Ritchie & 136.0 & 100.0 & 25.3 & 92.5 & 92.1 & 93.6 & 92.3 \\
\hline Roaoe & 130.7 & 100.0 & 104.5 & 100.1 & 97.9 & 102,0 & 98.1 \\
\hline Summers & 1140 & 100.0 & 91.4 & 90.5 & 89.4 & 92.5 & 89.8 \\
\hline Taylor & 121.7 & 100.0 & 98.0 & 95.6 & 95.7 & 95.8 & 91.5 \\
\hline Tucker & 125.3 & 100.0 & 82.9 & 76.2 & 72.7 & 73.2 & 71.3 \\
\hline Tyler & 134.9 & 100.0 & 104.9 & 105.8 & 105.1 & 110.5 & 108.3 \\
\hline Upshur & 107.5 & 100.0 & 102.3 & 102.3 & 101.7 & 105.5 & 105.4 \\
\hline Wayoe & 102.3 & 100.0 & 107.4 & 107.0 & 106.9 & 108.6 & 107.8 \\
\hline Webster & 101.9 & 100.0 & 98.2 & 95.3 & 91.4 & 94.7 & 88.7 \\
\hline Wetzel & 130.7 & 100.0 & 99.9 & 100.4 & 103.6 & 105.0 & 108.0 \\
\hline Wirt $_{\text {int }}$ & 122.1 & 100.0 & 94.8 & 89.4 & 86.9 & 86.6 & 84.5 \\
\hline W̄ood & 96.3 & 100.0 & 112.6 & 120.3 & 125.0 & 130.3 & 134.2 \\
\hline Wyomiog & 83.9 & 100.0 & 116.5 & 122.8 & 122.4 & 122.5 & 120.0 \\
\hline TOTAL & 103.2 & 100.0 & 104.1 & 105.1 & 105.0 & 106.9 & 105.4 \\
\hline
\end{tabular}

Section IV EDUCATION
W. Ya. Univ.
Agr. Exp. Sta.
Bul. Na. 464

Page 53 


\section{TABLE 5A. THE RELATIONSHIP BETWEEN NUMBER OF SOPHOMORES OF THE PREVIOUS YEAR TO THE NUMBER OF JUNIORS OF THE SPECIFIED YEAR ENROLLED IN HIGH SCHOOLS FOR THE COUNTIES OF WEST VIRGINIA: THE RELATIONSHIP IS EXPRESSED AS THE PERCENTAGE OF JUNIORS TO SOPHOMORES}

These data may be interpreted, with caution, as a measure of the holding power of the high schools. The comparison is narrowed to a specified year with its preceding year in order to eliminate as nearly as possible the effects of migration. Even with this one-year span, the 1940 records for Cabell and Kanawlra counties reveal values of 102.3 and 101.2 , demonstrating the influence of of the migration factor.

Since there is considerable migration, local studies involving personal knowledge of migration and student attendance are needed if an accurate picture is to be obtained.

An examination of other grade levels reveal losses, but these in most cases are proportionally less than between the Junior and Sophomore classes. It should be remembered that some students in these grade levels may be exhausting the benefits formal education holds for them.
Section IV EDUCATION

W. Va. Univ.

Agr. Exp. Sta.

Bul. No. 464

Page 54

\begin{tabular}{|c|c|c|c|c|c|c|c|}
\hline COUNTY & 1940 & 1950 & 1955 & 1956 & 1957 & 1958 & 1959 \\
\hline Batbour & 87.6 & 84.6 & 81.8 & 83.7 & 80.0 & 90.7 & 90.1 \\
\hline Berkeley & 78.4 & 85.4 & 86.0 & 80.1 & 77.5 & 81.3 & 78.7 \\
\hline Boone & 80.6 & 85.6 & 82.8 & 81.1 & 85.9 & 84.0 & 84.9 \\
\hline Braxtoo & 91.0 & 88.8 & 85.6 & 81.9 & 84.3 & 91.4 & 91.8 \\
\hline Brooke & 82,9 & 88.1 & 83.5 & 87.7 & 85.7 & 83.7 & 81.0 \\
\hline Cabell & 102.3 & 88.6 & 82.5 & 83.4 & 85.9 & 90.8 & 86.4 \\
\hline Calhoun & 81.0 & 89.8 & 86.3 & 83.8 & 88.0 & 84.0 & 81.0 \\
\hline Clay & 91.3 & 87,9 & 82.6 & 80.0 & 85.0 & 85.7 & 87.9 \\
\hline Doddridge & 79.4 & 82.8 & 80.0 & 75.8 & 87.7 & 77.6 & 77.2 \\
\hline Fayetre & 81.1 & 87.6 & 82.7 & 81.8 & 82.3 & 83.8 & 83.7 \\
\hline Gilmer & 98.6 & 85.5 & 81.6 & 87.3 & 89.3 & 80.8 & 78.1 \\
\hline Grant & 81.8 & 90.4 & 85.5 & 92.9 & 88.1 & 89.5 & 86.5 \\
\hline Greeabrier & 88.1 & 84.0 & 85.4 & 80.3 & 84.5 & 84.9 & 82.2 \\
\hline Hampshire & 90.4 & 90.3 & 87.9 & 86.3 & 82.5 & 87.4 & 84.5 \\
\hline Hancock & 91.0 & 87.3 & 93.5 & 86.0 & 88.8 & 89.7 & 90.3 \\
\hline Hardy & 87.5 & 87.4 & 80.2 & 79.0 & 84.7 & 80.3 & 84.2 \\
\hline Hartison & 86.0 & 85.8 & 82.4 & 81.9 & 82.7 & 86.3 & 86.7 \\
\hline Jackson & 86.0 & 92.4 & 89.2 & 86.3 & 101.7 & 89.8 & 84.5 \\
\hline Jeffers on & 78.7 & 81.8 & 89.2 & 91.2 & 86.2 & 83.1 & 80.7 \\
\hline Kanawha & 101.2 & 84.9 & 85.7 & 84.9 & 87.1 & 87.7 & 86.3 \\
\hline Lewis & 97.0 & 86.2 & 81.8 & 92.4 & 79.9 & 88.2 & 93.0 \\
\hline Liacoln & 87.0 & 81.0 & 81.9 & 79.9 & 86.0 & 88.2 & 86.9 \\
\hline Logan & 82.6 & 76.6 & 76.1 & 74.9 & 79.0 & 77.3 & 73.1 \\
\hline McDowell & 75.5 & 80.3 & 81.0 & 78.7 & 82.6 & 86.7 & 73.2 \\
\hline Marion & 88.8 & 88.9 & 86.4 & 87.0 & 85.9 & 88.0 & 85.5 \\
\hline Marshall & 85.3 & 84.6 & 92.7 & 86.9 & 89.4 & 84.8 & 85.5 \\
\hline Mason & 82.9 & 82.5 & 81.4 & 84.8 & 73.7 & 97.5 & 89.3 \\
\hline Mercer & 93.5 & 83.2 & 78.3 & 80.8 & 82.7 & 84.7 & 83.5 \\
\hline Mineral & 83.5 & 86.3 & 90.8 & 88.8 & 89.9 & 91.2 & 95.2 \\
\hline Mingo & 78.5 & 84.3 & 80.3 & 84.7 & 82.5 & 83.7 & 81.9 \\
\hline Monongalia & 83.8 & 88.2 & 87.0 & 89.1 & 90.1 & 90.4 & 91.7 \\
\hline Montoe & 81.8 & 87.7 & 91.5 & 94.2 & 87.3 & 89.4 & 93.2 \\
\hline Morgan & 87.8 & 79.4 & 82.2 & 79.0 & 75.7 & 84.9 & 96.6 \\
\hline Nicholas & 90.5 & 84.0 & 85.0 & 86.9 & 85.0 & 86.5 & 83.1 \\
\hline Ohio & 85.8 & 85.5 & 87.7 & 85.7 & 86.8 & 88.6 & 85.4 \\
\hline Pendletoa & 97.0 & 82.9 & 89.0 & 91.7 & 92.3 & 95.0 & 91.5 \\
\hline Pleasants & 91.0 & 89.9 & 92.8 & 87.6 & 93.7 & 95.8 & 96.5 \\
\hline Pocahootas & 87.0 & 88.1 & 90.4 & 82.1 & 86.3 & 95.3 & 86.3 \\
\hline Preston & 90.0 & 88.3 & 82.1 & 84.2 & 87.4 & 90.2 & 85.7 \\
\hline Putaam & 87.9 & 93.9 & 91.7 & 88.7 & 89.9 & 95,6 & 84.7 \\
\hline Raleigh & 78.6 & 82.1 & 76.9 & 78.2 & 79.7 & 80.0 & 75.9 \\
\hline Raodolph & 82.0 & 87.5 & 83.2 & 80.7 & 86.0 & 86.8 & 79.3 \\
\hline Ritchie & 90.6 & 96.7 & 87.1 & 89.9 & 91.5 & 89.2 & 91.0 \\
\hline Roave & 89.7 & 90.2 & 82.3 & 90.6 & 90.5 & 86.0 & 89.5 \\
\hline Summers & 78.0 & 90.6 & 79.5 & 86.1 & 86.6 & 85.1 & 82.3 \\
\hline Taylor & 85.0 & 89.4 & 83.0 & 82,2 & 85.9 & 84.1 & 80.0 \\
\hline Tucker & 89.0 & 80.4 & 88.2 & 80.8 & 89.6 & 99.4 & 93.1 \\
\hline Tyler & 89.0 & 87.2 & 91.0 & 85.1 & 89.7 & 87.6 & 94.2 \\
\hline Upshtur & 80.8 & 76.8 & 87.2 & 81.8 & 89.9 & 82.1 & 89.5 \\
\hline Wayne & 78.6 & 78.5 & 81.3 & 82.1 & 82.9 & 84.5 & 87.4 \\
\hline Wehster & 58.0 & 85,2 & 82.6 & 82.8 & 80.6 & 88.8 & 82.5 \\
\hline Werzel & 94.8 & 94.4 & 87.3 & 87.7 & 96.4 & 87.0 & 87.8 \\
\hline Wirt & 93.0 & 84.0 & 87.3 & 80.7 & 88.4 & 95.3 & 87.8 \\
\hline Wood & 93,6 & 83.9 & 87.3 & 89.3 & 91.1 & 89.7 & 86.1 \\
\hline Wyoming & 94.7 & 84.3 & 82.0 & 90.1 & 88.6 & 80.7 & 82.6 \\
\hline TOTAL & 88.3 & 86.0 & 84.9 & 84.1 & 85.3 & 86.5 & 84.2 \\
\hline
\end{tabular}


TABLE 5B. INDEX OF THE RELATIONSHIP BETWEEN THE NUMBER OF

SOPHOMORES OF THE PREVIOUS YEAR TO THE NUMBER OF JUNIORS OF

THE SPECIFIED YEAR ENROLLED IN HIGH SCHOOLS

FOR THE COUNTIES OF WEST VIRGINIA, $1950=10 \mathrm{C}$

Data presented here are based on information in Table $5 \mathrm{~A}$,

Section IV.

\begin{tabular}{|c|c|c|c|c|c|c|c|}
\hline COUNTY & 1940 & 1950 & 1955 & 1956 & 1957 & 1958 & 1959 \\
\hline Barbour & 103.5 & 100.0 & 96.7 & 98.9 & 94.6 & 107.2 & 106.5 \\
\hline Berkeley & 91.8 & 100.0 & 100.7 & 93.8 & 90.7 & 95.2 & 92.2 \\
\hline Boone & 94.2 & 100.0 & 96.7 & 94.7 & 100.4 & 98.1 & 99.2 \\
\hline Braxton & 102.5 & 100.0 & 96.4 & 92.2 & 94.9 & 102.9 & 103.4 \\
\hline Brooke & 94.1 & 100.0 & 94.8 & 99.5 & 97.3 & 95.0 & 91.9 \\
\hline Cabell & 115.5 & 100.0 & 93.1 & 94.1 & 97.0 & 102.5 & 97.5 \\
\hline Calhoun & 90.2 & 100.0 & 96.1 & 93.3 & 98.0 & 93.5 & 90.2 \\
\hline Clay & 103,9 & 100.0 & 94.0 & 91.0 & 96.7 & 97.5 & 100,0 \\
\hline Doddridge & 95.9 & 100.0 & 96.6 & 91.5 & 105.9 & 93.7 & 93.2 \\
\hline Fayette & 92.6 & 100.0 & 94.4 & 93.4 & 93.9 & 95.7 & 95.5 \\
\hline Gilmer & 115.3 & 100.0 & 95.4 & 102.1 & 104.4 & 94.5 & 91.3 \\
\hline Grant & 90.5 & 100,0 & 94.6 & 102,8 & 97.4 & 99.0 & 95.7 \\
\hline Green brier & 104.9 & 100.0 & 101.7 & 95.6 & 100.6 & 101.1 & 97.9 \\
\hline Hampshire & 100.1 & 100.0 & 97.3 & 95.6 & 91.4 & 96.8 & 93.6 \\
\hline Hancock & 104.2 & 100.0 & 107.1 & 98.5 & 101.7 & 98.6 & 103.4 \\
\hline Hardy & 100.1 & 100.0 & 91.8 & 90.4 & 96.9 & 91.9 & 96.3 \\
\hline Harrison & 100.2 & 100.0 & 96.0 & 95.4 & 96.4 & 100.6 & 101.0 \\
\hline Jackson & 93.1 & 100.0 & 96.5 & 100.3 & 110.1 & 97.2 & 91.4 \\
\hline Jefferson & 96.2 & 100.0 & 113.3 & 111.5 & 105.4 & 101.6 & 98.7 \\
\hline Kanawha & 119.2 & 100.0 & 100.9 & 100.0 & 102.6 & 103.3 & 101.6 \\
\hline Lewis & 112,5 & 100.0 & 94.9 & 107.2 & 92.7 & 102.3 & 107.9 \\
\hline Lincnln & 107.4 & 100.0 & 101.0 & 98,6 & 106.2 & 108,9 & 107.3 \\
\hline Logan & 107.8 & 100.0 & 99.3 & 97.8 & 103.1 & 100.9 & 95.4 \\
\hline McDowell & 94.0 & 100.0 & 100.9 & 98.0 & 102.9 & 108.0 & 91.2 \\
\hline Marion & 99.9 & 100.0 & 97.2 & 97.9 & 96.6 & 99.0 & 96.2 \\
\hline Marshall & 100.8 & 100.0 & 109.6 & 102.7 & 105.7 & 100.2 & 101.1 \\
\hline Masoo & 100.5 & 100.0 & 98.7 & 102.8 & 89.3 & 118.2 & 108.2 \\
\hline Mercer & 112.4 & 100.0 & 94.1 & 97.1 & 99.4 & 101.8 & 100.4 \\
\hline Mineral & 96.8 & 100.0 & 105.2 & 102.9 & 104.2 & 105.7 & 110.3 \\
\hline Miogo & 93.1 & 100.0 & 95.2 & 100.5 & 97.9 & 99.3 & 97.2 \\
\hline Mnnnngalia & 95.0 & 100.0 & 98.6 & 101.0 & 102.2 & 102.5 & 104.0 \\
\hline Mooroe & 93.3 & 100.0 & 104.3 & 107.4 & 99.5 & 101.9 & 106.3 \\
\hline Morgan & 110.6 & 100.0 & 103.5 & 99.5 & 95.3 & 106.9 & 121.7 \\
\hline Nicholas & 107.7 & 100.0 & 101.2 & 103.4 & 101.2 & 103.0 & 98.9 \\
\hline Ohio & 100.4 & 100.0 & 102.6 & 100.2 & 101.5 & 103.6 & 99.9 \\
\hline Pendleton & 117.0 & 100.0 & 107.4 & 110.6 & 111.3 & 114.6 & 110.4 \\
\hline Pleasants & 101.2 & 100.0 & 103.2 & 97.4 & 104.2 & 106.6 & 107.3 \\
\hline Pocahootas & 98.8 & 100.0 & 102.6 & 93.2 & 98.0 & 108.2 & 98.0 \\
\hline Prestoo & 101.9 & 100.0 & 93.0 & 95.4 & 99.0 & 102.2 & 97.1 \\
\hline Putoam & 93.6 & 100.0 & 97.6 & 94.5 & 95.7 & 101.8 & 90.2 \\
\hline Raleigh & 95.7 & 100.0 & 93.7 & 95.2 & 97,1 & 97,4 & 92.4 \\
\hline Randolph & 93.7 & 100.0 & 95.1 & 92.2 & 98.3 & 99.2 & 90.6 \\
\hline Ritchie & 93.7 & 100.0 & 90.1 & 93.0 & 94.6 & 92.2 & 94.1 \\
\hline Roaoe & 99.4 & 100.0 & 91.2 & 100,4 & 100.3 & 95.3 & 99.2 \\
\hline Summers & $\frac{22}{86,1}$ & 100.0 & 87.7 & 95.0 & 95.6 & 93.9 & 90.8 \\
\hline Taylor & 95.1 & 100.0 & 92.8 & 91.9 & 96.1 & 94.1 & 89.5 \\
\hline Tucker & 110.7 & 100.0 & 109.7 & 100.5 & 111.4 & 123.6 & 115.8 \\
\hline Tyler & 102.1 & 100.0 & 104.4 & 97.6 & 102.9 & 100.4 & 108.0 \\
\hline Upshur & 105.2 & 100.0 & 113.5 & 106.5 & 117.0 & 106.9 & 116.5 \\
\hline Wayne & 100,1 & 100.0 & 103.6 & 104.6 & 105.6 & 107.6 & 111.3 \\
\hline Webster & 68,1 & 100.0 & 96.9 & 97.2 & 94.6 & 104.2 & 96.8 \\
\hline Wetzel & 100.4 & 100.0 & 92.5 & 92.9 & 102.1 & 92.2 & 93.0 \\
\hline Wirt & 110.7 & 100.0 & 103.9 & 96.1 & 105.2 & 113.4 & 104.5 \\
\hline Wood & 111.6 & 100.0 & $104-0$ & $105-4$ & 108,6 & 106.9 & 102,6 \\
\hline Wyoming & 112.3 & 100.0 & 97.3 & 106.9 & 105.1 & 95.7 & 98.0 \\
\hline TOTAL & 100.3 & 100.0 & 98.7 & 98.0 & 99.2 & 100.1 & 97.9 \\
\hline
\end{tabular}

Section IV

EDUCATION

W. Va. Univ.

Agr. Exp. Sta.

Bul. No. 464 



\section{Section V}

\section{HEALTH}

1A The Number of General Hospital Beds Located in the Counties of West Virginia ....

$1 B$ Index of the Number of General Hospital Beds Located in the Counties of West Virginia, $1950=100 \ldots$.

2A Number of Persons, Located in the Counties of West Virginia, Licensed to Practice Medicine ....

2B Index of Number of Persons, Located in the Counties of West Virginia, Licensed to practice Medicine, $1950=100 \ldots \ldots$

3A Number of Registered Dentists Licensed to Practice Dentistry in in West Virginia, by County of Residence for the Counties of West Virginia ....

3B Index of Number of Registered Dentists Licensed to Practice Dentistry in West Virginia, by County of Residence for the Counties of West Virginia, $1952=100 \ldots$

4A The Number of Registered Nurses Located in the Counties of West Virginia ....

4B Index of the Number of Nurses Located in the Counties in West Virginia, $1952=100 \ldots \ldots$ 
The data presented in this table were prepared from the reports of Hospitals and Medical Facilities Bureau of the State Department of Health. These data were furnished by Dr. H. N. Dyer,

Director of the State Department of Health, and Mr. Paul D. Bibby, Chief of the Bureau.

Section $V$

HEALTH

W. Va. Unir.

Agr. Exp. Sto.

Bul. Na. 464

Page 58

\begin{tabular}{|c|c|c|c|c|c|c|c|}
\hline COUNTY & 1950 & 1955 & 1956 & 1957 & 1958 & 1959 & 1960 \\
\hline Barbour & 69 & 106 & 102 & 100 & 102 & 102 & 102 \\
\hline Berkeley & 179 & 223 & 223 & 218 & 138 & 233 & 233 \\
\hline Boone & 35 & 30 & 50 & Wh & & 50 & 50 \\
\hline Braxton & 65 & 59 & 1,6 & 19 & 38. & 51 & 51 \\
\hline Brooke & & & & & & 8 & 8 \\
\hline Cabell & 700 & 672 & 542 & 743 & 802 & 984 & 986 \\
\hline Calhouo & & & & & 30 & 25 & 25 \\
\hline \multicolumn{8}{|l|}{ Clay } \\
\hline \multicolumn{8}{|l|}{ Doddridge } \\
\hline Fayette & 200 & 199 & 199 & 196 & 200 & 200 & 200 \\
\hline \multicolumn{8}{|l|}{ Gilmer } \\
\hline Grant & & & & & 47 & 52 & 52 \\
\hline Greenbrier & 58 & 48 & 48 & 56 & 58 & 58 & 58 \\
\hline Hampshire & & & & & 40 & 10 & ho \\
\hline Haocock & 17 & 171 & 191 & 189 & 175 & 191 & 191 \\
\hline \multicolumn{8}{|l|}{ Hardy } \\
\hline Harrison & 259 & 265 & 265 & 244 & 260 & 361 & 361 \\
\hline Jackson & 15 & 11 & 11 & 10 & & 11 & 52 \\
\hline Jefferson & 10 & 42 & 42 & 41 & 42 & 42 & 42 \\
\hline Kanawha & 981 & 1,281 & 1,297 & 1,233 & 1,150 & 1,410 & 1,446 \\
\hline Lewis & 85 & 76 & 74 & 85 & 87 & 83 & 84 \\
\hline \multicolumn{8}{|l|}{ Lincoln } \\
\hline Logan & 205 & 194 & 194 & 276 & 184 & 272 & 270 \\
\hline McDowell & 300 & 291 & 291 & 291 & 296 & 296 & 296 \\
\hline Marioa & 139 & 210 & 210 & 209 & 212 & 212 & 212 \\
\hline Marshall & 99 & 99 & 99 & 97 & 20 & 100 & 100 \\
\hline Mason & 9 & & & & 40 & 52 & 52 \\
\hline Mercer & 282 & 327 & 321 & 280 & 358 & 342 & 342 \\
\hline Mineral & 59 & 58 & 58 & 58 & 58 & 60 & 60 \\
\hline Mingo & 110 & 123 & 95 & 98 & 100 & 100 & 100 \\
\hline Mooongalia & 205 & 202 & 199 & 188 & 492 & 746 & 746 \\
\hline \multicolumn{8}{|l|}{ Monfoe } \\
\hline Morgan & 40 & 42 & 42 & 37 & 41 & 41 & 34 \\
\hline Nicholas & 35 & 105 & 60 & 114 & 78 & 85 & 85 \\
\hline Ohio & 540 & 568 & 568 & 553 & 508 & 743 & 756 \\
\hline \multicolumn{8}{|l|}{ Pendletoo } \\
\hline \multicolumn{8}{|l|}{ Pleasants } \\
\hline Pocabontas & 31 & & 54 & 54 & 54 & 45 & 45 \\
\hline Preston & & & 76 & 76 & 76 & 76 & 76 \\
\hline \multicolumn{8}{|l|}{ Putnam } \\
\hline Raleigh & 270 & 279 & 279 & 437 & 467 & 467 & 455 \\
\hline Randolph & 203 & 199 & 189 & 770 & 90 & 213 & 213 \\
\hline \multicolumn{8}{|l|}{ Ritchie } \\
\hline Roane & 38 & 45 & 45 & 53 & 45 & 45 & 45 \\
\hline Summers & 75 & 75 & 75 & 72 & 75 & 75 & -83 \\
\hline Taylor & 66 & 66 & 66 & 63 & 66 & 66 & 66 \\
\hline Tucker & 38 & 48 & 48 & 1,6 & & 49 & 49 \\
\hline Tylex & 20 & 20 & 20 & 17 & 4 & 18 & 18 \\
\hline Upshur & Lل L & 80 & 102 & 91 & 39 & 91 & 91 \\
\hline Wayne & 16 & & & & & & \\
\hline Webster & & 31 & 31 & 28 & 31 & 31 & 32 \\
\hline Wetzel & 35 & 54 & $\frac{21}{54}$ & 51 & 55 & 81 & 81 \\
\hline \multicolumn{8}{|l|}{ Wirt } \\
\hline Wood & 170 & 407 & 407 & 376 & 331 & 553 & 553 \\
\hline Wyoming & 26 & 45 & $\frac{75}{45}$ & 45 & 65 & 65 & 65 \\
\hline TOTAL & 5,758 & 6,751 & 6.718 & 6,988 & 7,024 & 8,825 & 8,905 \\
\hline
\end{tabular}


TABLE 1B. INDEX OF THE NUMBER OF GENERAL HOSPITAL BEDS LOCATED

IN THE COUNTIES OF WEST VIRGINIA $1950=100$

The information presented in this table is based npon Table 1A, Section V.

\begin{tabular}{|c|c|c|c|c|c|c|c|}
\hline COUNTY & 1950 & 1955 & 1956 & 1957 & 1958 & 1959 & 1960 \\
\hline Basbour & 100.0 & 153.6 & 147.8 & Whe.2 & 147.8 & 147.8 & 147.8 \\
\hline Betkeley & 100.0 & 124.6 & 124.6 & 121.8 & 77.1 & 130.2 & 130.2 \\
\hline Boone & 100.0 & 85.7 & 142.9 & 125.7 & & 142.9 & 112.9 \\
\hline Braxtoo & 100.0 & 90.8 & 70.8 & 75.4 & 58.5 & 78.5 & 78.5 \\
\hline Brooke & & & & & & 100.0 & 100.0 \\
\hline Cahell & 100.0 & 96.0 & 72.4 & 106.1 & 114.6 & 140.6 & 140.9 \\
\hline Calhoun & & & & & 100.0 & 100.0 & 100.0 \\
\hline \multicolumn{8}{|l|}{ Clay } \\
\hline \multicolumn{8}{|l|}{ Doddridge } \\
\hline Fayette & 100.0 & 99.5 & 99.5 & 98.0 & 100.0 & 100.0 & 100.0 \\
\hline \multicolumn{8}{|l|}{ Gilmer } \\
\hline Grant & & & & & 100.0 & 100.0 & 100.0 \\
\hline Greea brier & 100.0 & 82.8 & 82.8 & 26.6 & 100.0 & 100.0 & 100.0 \\
\hline Hampshite & & & & & & 100.0 & 100.0 \\
\hline Hancock & 100.0 & 100.6 & 112,4 & 111.2 & 102.9 & $1,123,5$ & $1,123.5$ \\
\hline \multicolumn{8}{|l|}{ Hardy } \\
\hline Harrison & 100,0 & 102.3 & 102.3 & 94.2 & 100.4 & 139.4 & 139.4 \\
\hline Jacksoa & 100.0 & 73.3 & 73.3 & 66.7 & & 73.3 & 346.7 \\
\hline Jefferson & 100.0 & $105 . \Omega$ & 105.0 & 102.5 & 105.0 & 105.0 & 105,0 \\
\hline Kanawha & 100.0 & 130.6 & 132.2 & 125.7 & 117.2 & 143.7 & 147.4 \\
\hline Lewis & 100.0 & 89.4 & 87.1 & 100.0 & 102.4 & 97.6 & 98.8 \\
\hline \multicolumn{8}{|l|}{ Lincoln } \\
\hline Logan & 100.0 & 94.6 & 94.6 & 134.6 & 89.8 & 132.7 & 131.7 \\
\hline McDowell & 100.0 & 97.0 & 97.0 & 97.0 & 98.7 & 98.7 & 98.7 \\
\hline Marioa & 100.0 & 151.1 & 151.1 & 150.4 & 152.5 & 152.5 & 152.5 \\
\hline Marshall & 100.0 & 100.0 & 100.0 & 98.0 & 92.0 & 101.0 & 101.0 \\
\hline Mason & & & & & Whald & 577.8 & 577.3 \\
\hline Mercer & 100.0 & 116.0 & 113.8 & 99.3 & 127.0 & 121.3 & 121.3 \\
\hline Mineral & 100.0 & 98.3 & 98.3 & 98.3 & 98.3 & 101.7 & 101.7 \\
\hline Miago & 100.0 & 111.8 & 86.4 & 89.1 & 90.9 & 90.9 & 90.9 \\
\hline Monoogalia & 100.0 & 98.5 & 97.1 & 91.7 & 240.0 & 363.9 & 363.9 \\
\hline \multicolumn{8}{|l|}{ Monroe } \\
\hline Morgaa & 100.0 & 105.0 & 105.0 & 92.5 & 102.5 & 102.5 & 85.0 \\
\hline Nicholas & 100.0 & 300.0 & $170 \mathrm{ds}$ & 325.7 & 222.9 & 2142.9 & 242.9 \\
\hline Ohio & 100.0 & 105.2 & 105.2 & $102 \mathrm{a}$ & 94.1 & 137.6 & 140.0 \\
\hline \multicolumn{8}{|l|}{ Pendletoa } \\
\hline \multicolumn{8}{|l|}{ Pleasants } \\
\hline Pocahnotas & 100.0 & & $17 \mathrm{h.} .2$ & 174.2 & 174.2 & 145.2 & 145.2 \\
\hline Preston & & & 100.0 & 100.0 & 100,0 & 100.0 & 100.0 \\
\hline \multicolumn{8}{|l|}{ Putaam } \\
\hline Raleigh & 100.0 & 103.3 & 103.3 & 161.9 & 173.0 & 173.0 & 168.5 \\
\hline Raadolph & 100.0 & 98.0 & 93.1 & 83.7 & Lu. 3 & 104.9 & 104.9 \\
\hline \multicolumn{8}{|l|}{ Ritchic } \\
\hline Roane & 100.0 & 118.4 & 118.4 & 139.5 & 118.4 & 118.4 & 118.4 \\
\hline Summers & 100.0 & 100.0 & 100.0 & 96.0 & 100.0 & 100.0 & 110.7 \\
\hline Taylor & 100.0 & 100.0 & 100.0 & 95.5 & 100.0 & 100.0 & 100.0 \\
\hline Tucker & $100_{2} 0$ & 126.3 & 126.3 & 121.1 & & 128.9 & 128.9 \\
\hline Tyler & 100.0 & 100.0 & 100.0 & 85.0 & 20.0 & 90.0 & 90.0 \\
\hline Upshur & 100.0 & 181.8 & 231.8 & 206.8 & 88.6 & 206.8 & 206.8 \\
\hline Wayne & 100.0 & & & & & & \\
\hline Webster & & 100.0 & 100.0 & 90.3 & 100.0 & 100.0 & 100.0 \\
\hline Wetzel & 100.0 & $15 \mathrm{~h} .3$ & 154.3 & 1.5 .7 & 157.1 & 231.4 & 231.4 \\
\hline \multicolumn{8}{|l|}{ Wirt } \\
\hline Wood & 100.0 & 239.4 & 239.4 & 221.2 & 194.7 & 325.3 & 325.3 \\
\hline Wyoming & 100.0 & 173.1 & 173.1 & 173.1 & 250.0 & 250.0 & 250.0 \\
\hline TOTAL & 100.0 & 117.2 & & 121.4 & 122.0 & 153.3 & 154.7 \\
\hline
\end{tabular}

Section $V$

HEALTH

W. Va. Univ.

Agr. Exp. Sta. Bul. Na. 464

Page 59 


\section{TABLE 2A. NUMBER OF PERSONS LOCATED IN THE COUNTIES OF WEST VIRGINIA, LICENSED TO PRACTICE MEDICINE}

Persons licensed to practice medicine in West Virginia include medical doctors and osteopaths. Sources for the data presented here are the American Medical Directory, reports of The Medical Licensing Board of West Virginia, and the West Virginia Board of Osteopathy. Adjustments as to date and availability of licensee were occasionally required. Discussion of the procedures used in making such adjustments will be provided, if requested.

NOTE: In certain instances doctors were reported from cities that are located in two counties. In these cases, the doctors were credited to the county in which the greater portion of the city's population is located.
Section V

HEALTH

W. Va. Univ.

Agr. Exp. Sta.

Bul. No. 464

Page 60

\begin{tabular}{|c|c|c|c|c|}
\hline COUNTY & 1938 & 1950 & 1957 & 1960 \\
\hline Barbour & 15 & 17 & 17 & 20 \\
\hline Berkeley & 32 & 30 & 34 & 34 \\
\hline Boone & 14 & 21 & 20 & 16 \\
\hline Braxton & 17 & 16 & 7 & 6 \\
\hline Brooke & 10 & 20 & 14 & 17 \\
\hline Cabell & 153 & 172 & 164 & 164 \\
\hline Calhoun & 6 & 5 & 3 & 5 \\
\hline Clay & 5 & 4 & 3 & 4 \\
\hline Doddridge & 10 & 5 & 4 & 2 \\
\hline Fayette & 71 & 59 & 36 & 31 \\
\hline Gilmer & 7 & 4 & 4 & 4 \\
\hline Grant & 6 & 5 & 5 & 6 \\
\hline Greenbrier & 33 & 34 & 35 & 38 \\
\hline Hampshire & 6 & 4 & 5 & 5 \\
\hline Hancock & 30 & 24 & 31 & 30 \\
\hline Hardy & 7 & 6 & 6 & 7 \\
\hline Harrison & 94 & 90 & 84 & 76 \\
\hline Jackson & 14 & 8 & 8 & 12 \\
\hline Jefferson & 14 & 11 & 12 & 10 \\
\hline Kanawha & 245 & 320 & 299 & 308 \\
\hline Lewis & 33 & 28 & 18 & 16 \\
\hline Lincnln & 8 & 5 & 4 & 4 \\
\hline Logan & 63 & 48 & 51 & 42 \\
\hline McDowell & 82 & 69 & 51 & 48 \\
\hline Marion & 76 & 66 & 61 & 76 \\
\hline Marshall & 24 & 19 & 18 & 19 \\
\hline Mason & 15 & 16 & 19 & 19 \\
\hline Mercer & 78 & 73 & 79 & 81 \\
\hline Mineral & 15 & 12 & 15 & 15 \\
\hline Mingo & 35 & 26 & 39 & 37 \\
\hline Mooongalia & 62 & 62 & 57 & 57 \\
\hline Monroe & 13 & 12 & 12 & 8 \\
\hline Morgan & 3 & 6 & 3 & 6 \\
\hline Nicholas & 15 & 17 & 18 & 14 \\
\hline Ohio & 138 & 131 & 121 & 124 \\
\hline Pendleton & 5 & 4 & 4 & 4 \\
\hline Pleasants & 8 & 6 & 4 & 7 \\
\hline Pocahontas & 14 & 8 & 9 & 8 \\
\hline$\overline{\text { Preston }}$ & 23 & 19 & 18 & 15 \\
\hline Putnam & 10 & 5 & 3 & 6 \\
\hline Raleigh & 73 & 91 & 115 & 124 \\
\hline Randslph & 31 & 25 & 33 & 38 \\
\hline Ritchie & 15 & 5 & 5 & 5 \\
\hline Roaoe & 18 & 12 & 10 & 8 \\
\hline Summers & 12 & 10 & 13 & 11 \\
\hline Taylor & 14 & 15 & 15 & 10 \\
\hline Tucker & 11 & 4 & 4 & 3 \\
\hline Tyler & 9 & 10 & 4 & 4 \\
\hline Upahur & 18 & 15 & 14 & 10 \\
\hline Wayne & 12 & 12 & 8 & 7 \\
\hline Webster & 8 & 7 & 8 & 8 \\
\hline Wetzel & 21 & 15 & 15 & 15 \\
\hline Wirt & 1 & 2 & 1 & 1 \\
\hline Wood & 80 & 84 & $\frac{1}{81}$ & 80 \\
\hline Wyoming & 19 & $\frac{04}{16}$ & 19 & 20 \\
\hline TOTAL & 1,856 & 1,807 & 1,740 & 1,745 \\
\hline
\end{tabular}


TABLE 2B. INDEX OF NUMBER OF PERSONS, LOCATED IN THE COUNTIES

OF WEST VIRGINIA, LICENSED TO PRACTICE MEDICINE, $1950=100$

The data presented in this table are based upon the information in the preceding table, Table $2 \mathrm{~A}$, Section V.

\begin{tabular}{|c|c|c|c|c|}
\hline COUNTY & 1938 & 1950 & 1957 & 1960 \\
\hline Barbour & 88,2 & 100,0 & 100.0 & 117.6 \\
\hline Berkeley & 106.7 & 100.0 & 113.3 & 113.3 \\
\hline Bopne & 66.7 & 100.0 & 95.2 & 76.2 \\
\hline Braxton & 106.2 & 100.0 & 43.8 & 37.5 \\
\hline Brnoke & 50.0 & 100.0 & 70.0 & 85.0 \\
\hline Cabell & 89.0 & 100.0 & 95.3 & 95.3 \\
\hline Calhoun & 120.0 & 100.0 & 60.0 & 100.0 \\
\hline Clay & 125.0 & 100.0 & 75.0 & 100.0 \\
\hline Doddridge & 200.0 & 100.0 & 80.0 & 40.0 \\
\hline Fayette & 120.3 & 100.0 & 61.0 & 52.5 \\
\hline Gilmes & 175.0 & 100.0 & 100.0 & 100.0 \\
\hline Grant & 120.0 & 100.0 & 100.0 & 120.0 \\
\hline Green brier & 97.1 & 100.0 & 102.9 & 111.8 \\
\hline Hampshire & 150.0 & 100.0 & 125.0 & 125.0 \\
\hline HancDck & 125.0 & 100.0 & 129.2 & 125.0 \\
\hline Hardy & 116.7 & 100.0 & 100.0 & 116.7 \\
\hline Harrison & 104.4 & 100.0 & 93.3 & 84.4 \\
\hline Jackson & 175.0 & 100.0 & 100.0 & 150.0 \\
\hline Jefferson & 127.3 & 100.0 & 109.1 & 90.9 \\
\hline Kanawha & 76.6 & 100.0 & 93.4 & 96.2 \\
\hline Lewis & 117.9 & 100.0 & 64.3 & 57.1 \\
\hline Lincoln & 160.0 & 100.0 & 80.0 & 80.0 \\
\hline Logan & 131.2 & 100.0 & 106.2 & 87.5 \\
\hline McDowell & 118.8 & 100.0 & 73.9 & 69.6 \\
\hline Marion & 115.2 & 100.0 & 92.4 & 115.2 \\
\hline Marshall & 126.3 & 100.0 & 94.7 & 100.0 \\
\hline Masnn & 93.8 & 100.0 & 118.8 & 118.8 \\
\hline Mercer & 106.8 & 100.0 & 108.2 & 111.0 \\
\hline Mineral & 125.0 & 100.0 & 125.0 & 125.0 \\
\hline Mingo & 134.6 & 100.0 & 150.0 & 142.3 \\
\hline Monongalia & 100.0 & 100.0 & 91.9 & 91.9 \\
\hline Monrpe & 108.3 & 100.0 & 100,0 & 66.7 \\
\hline Mnrgan & 133.3 & 100.0 & 50.0 & 100.0 \\
\hline Nichalas & 88.2 & 100.0 & 105.9 & 82.4 \\
\hline Obio & 105.3 & 100.0 & 92.4 & 94.7 \\
\hline Pendleton & 125.0 & 100.0 & 100.0 & 100.0 \\
\hline Pleasants & 133.3 & 100.0 & 66.7 & 116.7 \\
\hline Pocahontas & 175.0 & 100.0 & 112.5 & 100.0 \\
\hline Preston & 121.1 & 100.0 & 94.7 & 78.9 \\
\hline Putnam & 200.0 & 100.0 & 60.0 & 120.0 \\
\hline Raleigh & 80.2 & 100.0 & 126.4 & 136.3 \\
\hline Randolph & 124.0 & 100.0 & 132.0 & 152.0 \\
\hline Ritchie & 300.0 & 100.0 & 100.0 & 100.0 \\
\hline Roane & 150.0 & 100.0 & 83.3 & 66.7 \\
\hline Summers & 120.0 & 100.0 & 130.0 & 110.0 \\
\hline Taylor & 93.3 & 100.0 & 100.0 & 66.7 \\
\hline Tucker & 275.0 & 100.0 & 100.0 & 75.0 \\
\hline Tylet & 90.0 & 100.0 & 40.0 & 40.0 \\
\hline Upshur & 120.0 & 100.0 & 93.3 & 66.7 \\
\hline Wayne & 133.3 & 100.0 & 88.9 & 77.8 \\
\hline Webster & 114.3 & 100.0 & 114.3 & 114.3 \\
\hline Wetzel & 140.0 & 100.0 & 100.0 & 100.0 \\
\hline Wirt & 50.0 & 100.0 & 50.0 & 50.0 \\
\hline Wnad & 95.2 & 100.0 & 96,4 & 95.2 \\
\hline Wyoming & 118,8 & 100.0 & 118.8 & 125.0 \\
\hline TOTAL & 102.7 & 100.0 & 96.3 & 96.6 \\
\hline
\end{tabular}

Section $V$ HEALTH

W. Va. Univ.

Agr. Exp. Sta.

Bul. No. 464 


\section{TABLE 3A. NUMBER OF REGISTERED DENTISTS LICENSED TO PRACTICE DENTISTRY IN WEST VIRGINIA, BY COUNTY OF RESIDENCE FOR THE COUNTIES OF WEST VIRGINIA}

In a few instances, such as in the case of Huntington, the city occupies area in more than one county. In these cases, the dentists were all credited to the county in which the major portion of the city's population is located. As was the case when compiling Table $2 \mathrm{~A}$, Section $\mathrm{V}$, it is the intention of the author to report the availability of the practitioner to the general public in the counties. It is expected that improvement in this regard will be possible in subsequent publications.

Section $V$

HEALTH
W. Va. Univ.

Agr. Exp. Sta.

Bul. No. 464

Page 62

\begin{tabular}{|c|c|c|c|c|c|c|c|}
\hline COUNTY & 1952 & 1955 & 1956 & 1957 & 1958 & 1960 & \\
\hline Barbour & 4 & 4 & 3 & 3 & 4 & 5 & \\
\hline Berkeley & 8 & 6 & 8 & 8 & 8 & 9 & \\
\hline Boone & 6 & 6 & 6 & 7 & 6 & 4 & \\
\hline Braxton & 1 & 2 & 3 & 3 & 3 & 3 & \\
\hline Brooke & 6 & 6 & 6 & 6 & 5 & 7 & \\
\hline Cabell & 59 & 73 & 71 & 73 & 71 & 68 & \\
\hline Calhouo & 1 & 1 & 1 & 1 & 1 & 1 & \\
\hline Clay & - & 1. & 1 & 1 & 3 & 3 & \\
\hline Doddridge & 2 & 2 & 2 & 2 & 2 & 2 & \\
\hline Fayette & 16 & 17 & 17 & 19 & 17 & 16 & \\
\hline Gilmer & 1 & 2 & 1 & 1 & 2 & 1 & \\
\hline Grant & 2 & 2 & 2 & 2 & 2 & 2 & \\
\hline Greenbrier & 18 & 14 & 12 & 14 & 15 & 14 & \\
\hline Hampshire & 2 & 3 & 3 & 4 & 4 & 6 & \\
\hline Hancock & 14 & 15 & 16 & 17 & 16 & 18 & \\
\hline Hardy & 4 & 3 & 2 & 2 & 3 & 3 & \\
\hline Harrisoo & 42 & 43 & 43 & 40 & 39 & 41 & \\
\hline Jackson & 4 & 4 & 5 & 4 & 5 & 6 & \\
\hline Jeffersoo & 6 & 5 & 5 & 6 & 5 & 5 & \\
\hline Kanawha & 115 & 120 & 126 & 127 & 125 & 114 & \\
\hline Lewis & 7 & 5 & 5 & 6 & 5 & 5 & \\
\hline Lincolo & 2 & 1 & 1 & 1 & 1 & 1 & \\
\hline Logaa & 13 & 13 & 12 & 12 & 12 & 9 & \\
\hline McDowell & 17 & 19 & 16 & 17 & 18 & 14 & \\
\hline Marion & 32 & 39 & 39 & 36 & 34 & 34 & \\
\hline Marshall & 8 & 8 & 9 & 9 & 11 & 8 & \\
\hline Mason & 6 & 6 & 7 & 7 & 7 & 5 & \\
\hline Mercer & 24 & 24 & 25 & 25 & 23 & 26 & \\
\hline Mineral & 7 & 9 & 8 & 8 & प9 & 9 & \\
\hline Mingo & 9 & 10 & 9 & 11 & 14 & 11 & \\
\hline Mooongalia & 24 & 29 & 28 & 29 & 33 & 36 & \\
\hline Monroe & 2 & 4 & 4 & 4 & 4 & 4 & \\
\hline Mnrgan & 2 & 1 & 2 & 1 & 1 & 1 & \\
\hline Nicholas & 4 & 5 & 5 & 5 & 6 & 5 & \\
\hline Ohio & 56 & 59 & 58 & 54 & 58 & 58 & \\
\hline Pendleton & 3 & 4 & 4 & 4 & 4 & 3 & \\
\hline Pleasanrs & 3 & 3 & 3 & 3 & 2 & 3 & \\
\hline Pocahootas & 2 & 2 & 2 & 2 & 2 & 2 & \\
\hline Prestoo & 7 & 8 & 7 & 8 & 7 & 5 & \\
\hline Putaam & 1 & 1 & 1 & 1 & 2 & 2 & \\
\hline Raleigh & 28 & 27 & 31 & 28 & 26 & 27 & \\
\hline Raadolph & 8 & 9 & 7 & 11 & 11 & 12 & \\
\hline Ritchie & 3 & 4 & 4 & 4 & 4 & 4 & \\
\hline Roane & 5 & 6 & 4 & 4 & 5 & 5 & \\
\hline Summers & 4 & 4 & 6 & 4 & 5 & 5 & \\
\hline Taylor & 4 & 7 & 5 & 5 & 6 & 3 & \\
\hline Tucker & 3 & 2 & 3 & 3 & 3 & 2 & \\
\hline Tyler & 3 & 3 & 3 & 2 & 2 & 2 & \\
\hline Upshur & 8 & 10 & 9 & 8 & 8 & 8 & \\
\hline Wayne & 4 & 5 & 5 & 6 & 6 & 6 & \\
\hline Webster & 2 & 3 & 3 & 3 & 4 & 1 & \\
\hline Wetzel & 8 & 8 & 9 & 10 & 10 & 12 & \\
\hline Wirt & 1 & 1 & 1 & 1 & 1 & 1 & \\
\hline Wood & 31 & 35 & 35 & 36 & 34 & 33 & \\
\hline Wyoming & 6 & 6 & 7 & 8 & 7 & 6 & \\
\hline TOTAL & 658 & 709 & 710 & 716 & 721 & 696 & \\
\hline
\end{tabular}


TABLE 3B. INDEX OF NUMBER OF REGISTERED DENTISTS LICENSED TO

PRACTICE DENTISTRY IN WEST VIRGINIA, BY COUNTY OF RESIDENCE

FOR THE COUNTIES OF WEST VIRGINIA, $1952=100$

The data presented in this table is based upon the preceding

table, Table 3A, Section V.

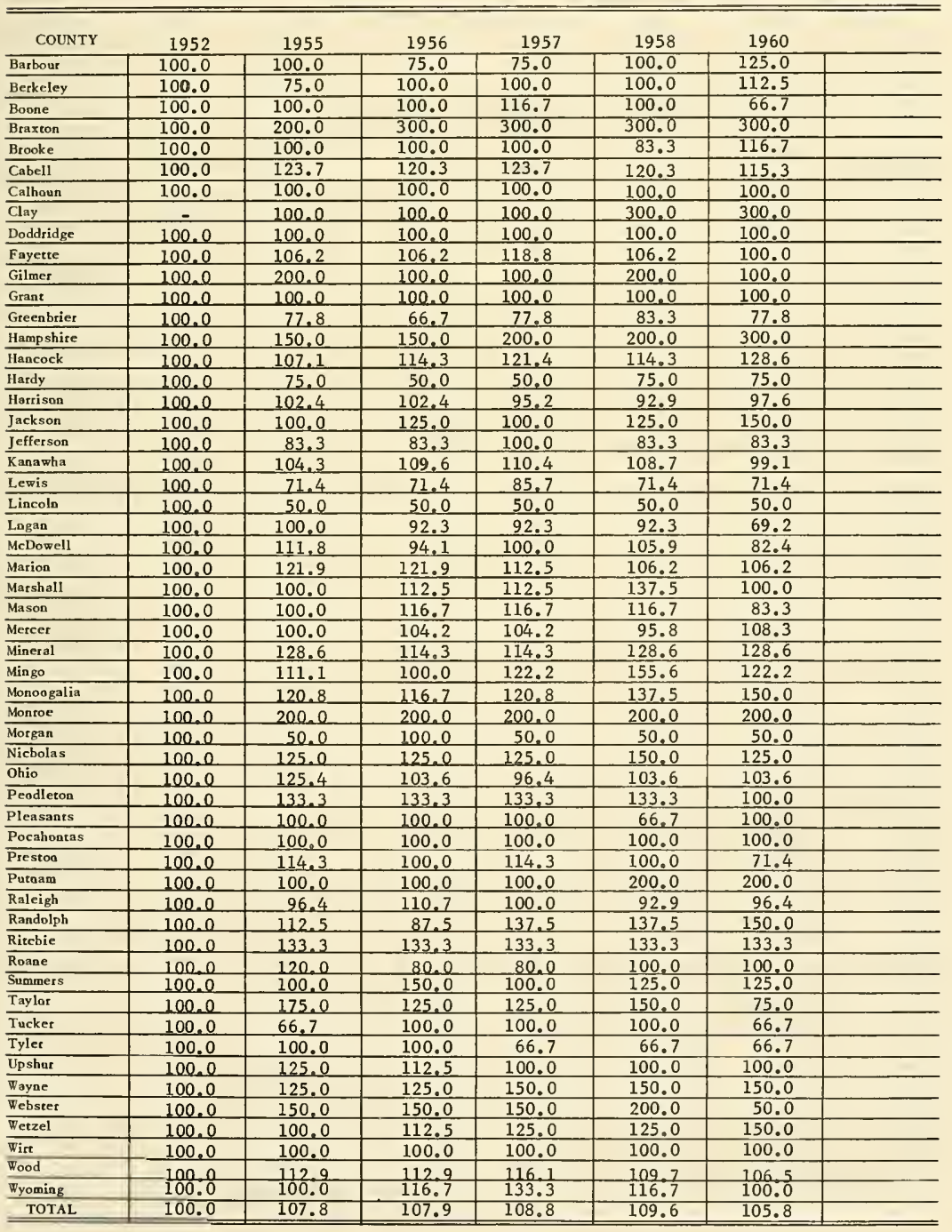

Section V

HEALTH

W. Va. Univ.

Agr. Exp. Sta.

Bul. No. 464

Page 63 
Data presented in this table are based upon information supplied by the Board of Examiners for Registered Nurses, Marjorie E. Dumez, R.N., Executive Secretary.

Nurses reported from cities occupying area in more than one county were credited to the county in which the major portion of that city's population was located.

Section V

HEALTH
W. Vo. Univ.

Agr. Exp. Sta.

Bul. Na. 464

Page 64

\begin{tabular}{|c|c|c|c|c|c|c|c|}
\hline COUNTY & 1952 & 1955 & 1956 & 1957 & 1958 & 1959 & 1960 \\
\hline Barbour & 22 & 30 & 32 & 26 & 27 & 31 & 32 \\
\hline Berkeley & 150 & 154 & 156 & 159 & 152 & 164 & 158 \\
\hline Boone & 21 & 25 & 14 & 16 & 16 & 15 & 18 \\
\hline Braxtoc & 13 & 9 & 11 & 10 & 9 & 6 & 6 \\
\hline Brnoke & 30 & 43 & 29 & 33 & 50 & 33 & 34 \\
\hline Cabell & 393 & 414 & 378 & 372 & 393 & 388 & 399 \\
\hline Calhoug & 4 & 2 & 4 & 2 & 1 & 3 & 5 \\
\hline Clay & 2 & 1 & 3 & 2 & 3 & 3 & 2 \\
\hline Doddridge & 6 & 3 & 3 & 3 & 1 & 2 & 1 \\
\hline Fayette & 105 & 109 & 114 & 102 & 103 & 87 & 87 \\
\hline Gilmet & 6 & 6 & 3 & 4 & 5 & 2 & 4 \\
\hline Grant & 3 & 8 & 5 & 5 & 9 & 16 & 13 \\
\hline Greecbrier & 54 & 60 & 41 & 40 & 36 & 37 & 38 \\
\hline Hampshire & 5 & 4 & 7 & 6 & 7 & 11 & 12 \\
\hline Haacock & 26 & 57 & 95 & 92 & 101 & 100 & 98 \\
\hline Hardy & 7 & 9 & 7 & 4 & 5 & 5 & 4 \\
\hline Harrison & 276 & 290 & 263 & 250 & 261 & 264 & 251 \\
\hline Jacksan & 10 & 7 & 6 & 11 & 13 & 12 & 12 \\
\hline Jefferson & 36 & 42 & 34 & 26 & 28 & 30 & 30 \\
\hline Kanawha & 800 & 858 & 729 & 726 & 753 & 746 & 733 \\
\hline Lewis & 46 & 53 & 47 & 45 & 40 & 41 & 42 \\
\hline Liocoln & 3 & 1 & 2 & - & - & 1 & 1 \\
\hline Logan & 61 & 67 & 72 & 80 & 101 & 86 & 75 \\
\hline McDowell & 83 & 84 & 80 & 80 & 73 & 62 & 54 \\
\hline Marion & 229 & 232 & 191 & 195 & 169 & 185 & 188 \\
\hline Marsball & 98 & 110 & 98 & 90 & 93 & 103 & 102 \\
\hline Ma son & 17 & 27 & 17 & 15 & 18 & 16 & 30 \\
\hline Mercer & 160 & 165 & 151 & 138 & 148 & 148 & 149 \\
\hline Mineral & 41 & 44 & 43 & 43 & 43 & 40 & 33 \\
\hline Mingo & 47 & 51 & 48 & 37 & 32 & 30 & 34 \\
\hline Moooagalia & 165 & 173 & 181 & 175 & 166 & 152 & 151 \\
\hline Mooroe & 13 & 13 & 9 & 9 & 6 & 5 & 6 \\
\hline Morgao & 10 & 8 & 6 & 11 & 12 & 13 & 16 \\
\hline Nicholas & 28 & 34 & 24 & 24 & 28 & 28 & 20 \\
\hline Ohio & 378 & 354 & 371 & 372 & 409 & 409 & 441 \\
\hline Peadleton & 1 & 3 & - & 1 & 1 & 4 & 2 \\
\hline Pleasants & 7 & 10 & 6 & 9 & 5 & 7 & 7 \\
\hline Pocahontas & 16 & 16 & 7 & 8 & 7 & 11 & 11 \\
\hline Preston & 33 & 39 & 31 & 39 & 39 & 38 & 36 \\
\hline Putnam & 17 & 28 & 8 & 14 & 13 & 19 & 15 \\
\hline Raleigh & 192 & 197 & 213 & 216 & 226 & 224 & 224 \\
\hline Raodolph & 77 & 75 & 65 & 65 & 66 & 71 & 67 \\
\hline Ritchie & 11 & 12 & 14 & 7 & 6 & 7 & 5 \\
\hline Roaoe & 26 & 25 & 19 & 18 & 15 & 19 & 13 \\
\hline Summers & 44 & 39 & 40 & 30 & 35 & 31 & 33 \\
\hline Taylor & 44 & 47 & 39 & 35 & 40 & 38 & 38 \\
\hline Tucker & 11 & 12 & 8 & 9 & 12 & 11 & 10 \\
\hline Tyler & 13 & 12 & 9 & 10 & 10 & 11 & 12 \\
\hline Upahur & 31 & 28 & 20 & 16 & 24 & 23 & 20 \\
\hline Wayoe & 38 & 38 & 37 & 29 & 24 & 34 & 33 \\
\hline Webster & 5 & 7 & 10 & 9 & 10 & 10 & 10 \\
\hline Wetzel & 44 & 44 & 34 & 36 & 38 & 34 & 39 \\
\hline Wirt & 4 & 7 & 7 & 4 & 4 & 3 & 2 \\
\hline Wood & 260 & 293 & 277 & 296 & 293 & 307 & 317 \\
\hline Wyoming & 20 & 22 & 19 & 17 & 20 & 18 & 21 \\
\hline TOTAL & 4,242 & 4.501 & 4.137 & 6 unknown. & 2 unknown & 1 unknown & 4 unknown \\
\hline & & & & 4,077 & 4,201 & 4,195 & 4,198 \\
\hline
\end{tabular}


TABLE 4B. INDEX OF THE NUMBER OF REGISTERED NURSES LOCATED IN THE COUNTIES IN WEST VIRGINIA, $1952=100$

Data presented in this table are based on the information in in the preceding table, Table $4 \mathrm{~A}$, Section $\mathrm{V}$.

\begin{tabular}{|c|c|c|c|c|c|c|c|}
\hline COUNTY & 1952 & 1955 & 1956 & 1957 & 1958 & 1959 & 1960 \\
\hline Barbour & 100 & 136 & 145 & 118 & 123 & 141 & 145 \\
\hline Berkeley & 100 & 103 & 104 & 106 & 101 & 109 & 105 \\
\hline Boone & 100 & 119 & 67 & 76 & 76 & 71 & 86 \\
\hline Braxton & 100 & 69 & 85 & 77 & 69 & 46 & 46 \\
\hline Btooke & 100 & 143 & 97 & 110 & 167 & 110 & 113 \\
\hline Cabell & 100 & 105 & 96 & 95 & 100 & 99 & 102 \\
\hline Calhnun & 100 & 50 & 100 & 50 & 25 & 75 & 125 \\
\hline Clay & 100 & 50 & 150 & 100 & 150 & 150 & 100 \\
\hline Doddridge & 100 & 50 & 50 & 50 & 17 & 33 & 17 \\
\hline Fayette & 100 & 104 & 109 & 97 & 98 & 83 & 83 \\
\hline Gilmer & 100 & 100 & 50 & 67 & 83 & 33 & 67 \\
\hline Grant & 100 & 267 & 167 & 167 & 300 & 533 & 433 \\
\hline Greenbrier & 100 & 111 & 76 & 74 & 67 & 69 & 70 \\
\hline Hampshire & 100 & 80 & 140 & 120 & 140 & 220 & 240 \\
\hline Hancock & 100 & 219 & 365 & 354 & 388 & 385 & 377 \\
\hline Hardy & 100 & 129 & 100 & 57 & 71 & 71 & 57 \\
\hline Hatrisoo & 100 & 105 & 95 & 91 & 95 & 96 & 91 \\
\hline Jackson & 100 & 70 & 60 & 110 & 130 & 120 & 120 \\
\hline Jefferson & 100 & 117 & 94 & 72 & 78 & 83 & 83 \\
\hline Kanawha & 100 & 107 & 91 & 91 & 94 & 93 & 92 \\
\hline Lewis & 100 & 115 & 102 & 98 & 87 & 89 & 91 \\
\hline Lincoln & 100 & 33 & 67 & 0 & 0 & 33 & 33 \\
\hline Lagan & 100 & 110 & 118 & 131 & 166 & 141 & 123 \\
\hline McDowell & 100 & 101 & 96 & 96 & 88 & 75 & 65 \\
\hline Marion & 100 & 101 & 83 & 85 & 74 & 81 & 82 \\
\hline Marshall & 100 & 112 & 100 & 92 & 95 & 105 & 104 \\
\hline Masoo & 100 & 159 & 100 & 88 & 106 & 94 & 176 \\
\hline Mercer & 100 & 103 & 94 & 86 & 92 & 92 & 93 \\
\hline Mineral & 100 & 107 & 105 & 105 & 105 & 98 & 80 \\
\hline Mingo & 100 & 109 & 102 & 79 & 68 & 64 & 72 \\
\hline Monoagalia & 100 & 105 & 110 & 106 & 101 & 92 & 92 \\
\hline Manroe & 100 & 100 & 69 & 69 & 46 & 38 & 46 \\
\hline Morgan & 100 & 80 & 60 & 110 & 120 & 130 & 160 \\
\hline Nicbolas & 100 & 121 & 86 & 86 & 100 & 100 & 71 \\
\hline Ohio & 100 & 94 & 98 & 98 & 108 & 108 & 117 \\
\hline Pendleton & 100 & 300 & 0 & 100 & 100 & 400 & 200 \\
\hline Pleasanrs & 100 & 143 & 86 & 129 & 71 & 100 & 100 \\
\hline Pocahootas & 100 & 100 & 44 & 50 & 44 & 69 & 69 \\
\hline Prestoo & 100 & 118 & 94 & 118 & 118 & 115 & 109 \\
\hline Putnam & 100 & 165 & 47 & 82 & 76 & 112 & 88 \\
\hline Raleigh & 100 & 103 & 111 & 112 & 118 & 117 & 117 \\
\hline Randolph & 100 & 97 & 84 & 84 & 86 & 92 & 87 \\
\hline Ritchie & 100 & 109 & 127 & 64 & 55 & 64 & 45 \\
\hline Roane & 100 & 96 & 73 & 69 & 58 & 73 & 50 \\
\hline Summers & 100 & 89 & 91 & 68 & 80 & 70 & 75 \\
\hline Taylor & 100 & 107 & 89 & 80 & 91 & 86 & 86 \\
\hline Tucker & 100 & 109 & 73 & 82 & 109 & 100 & 91 \\
\hline Tyler & 100 & 92 & 69 & 77 & 77 & 85 & 92 \\
\hline Upsbur & 100 & 90 & 65 & 52 & 77 & 74 & 65 \\
\hline Wayne & 100 & 100 & 97 & 76 & 63 & 89 & 87 \\
\hline Webster & 100 & 140 & 200 & 180 & 200 & 200 & 200 \\
\hline Werzel & 100 & 100 & 77 & 82 & 86 & 77 & 89 \\
\hline Wirt & 100 & 175 & 175 & 100 & 100 & 75 & 50 \\
\hline Wood & 100 & 113 & 107 & 114 & 113 & 118 & 122 \\
\hline Wyoming & 100 & 110 & 95 & 85 & 100 & 90 & 105 \\
\hline TOTAL & 100 & 106 & 97 & 96 & 99 & 99 & 99 \\
\hline
\end{tabular}

Section V

HEALTH

W. Va. Univ.

Agr. Exp. Sta.

Bul. Na. 464 



\section{Section VI}

\section{AGRICULTURE}

Table

Page

1 A The Total Milk Production (in Thousands of Pounds) for the Counties of West Virginia for Specified Years ....

$1 B$ Index to Total Milk Production for the Counties of West Virginia for Specified Years, $1954=100 \ldots$.

2A Total Egg Production (in Thousands) for the Counties of West Virginia for Specified Years ....

2B Index of Total Egg Production for the Counties of West Virginia for Specified Years, $1950=100 \ldots$. 


\section{TABLE 1A. THE TOTAL MILK PRODUCTION (IN THOUSANDS OF POUNDS) FOR THE COUNTIES OF WEST VIRGINIA FOR THE SPECIFIED YEARS}

The data presented in this table were taken from C. R. Bulletin No. 3, Agricultural Statistics, West Virginia - 1960, a publication of the Agricultural Marketing Service of the United States Department of Agriculture and the West Virginia Department of Agriculture. Earlier editions of this publication were also used. Much additional agricultural data, by county on an annual basis, may be found in these volumes.

Section VI AGRICULTURE

W. Yo. Univ. Agr. Exp. Sta. Bul. Na. 464

Page 68

\begin{tabular}{|c|c|c|c|c|c|c|c|}
\hline COUNTY & 1940 & 1954 & 1955 & 1956 & 1957 & 1958 & 1959 \\
\hline Barbour & & 15,800 & 14,600 & 14,500 & 14,300 & 14,200 & 13,300 \\
\hline Berkeley & & 32,600 & 34,800 & 35,000 & 35,200 & 36,000 & 38,100 \\
\hline Boone & & 2,100 & 1,900 & 1,900 & 1,700 & 1,500 & 1,600 \\
\hline Braxton & & 15,000 & 14,800 & 14,700 & 14,500 & 14,500 & 15,600 \\
\hline Brooke & & 5,500 & 5,400 & 5,700 & 5,700 & 5,400 & 5.600 \\
\hline Cabell & & 12,800 & 12,400 & 11,900 & 11,100 & 10,900 & 10,200 \\
\hline CaIhoun & & 9,500 & 9,200 & 9,000 & 9,000 & 8,700 & 8,500 \\
\hline Clay & & 5,200 & 5.400 & 5,100 & 4.600 & 4,400 & 4.200 \\
\hline Daddridge & & 10,700 & 10,300 & 10,600 & 10,700 & 11,100 & 10,600 \\
\hline Fayette & & 9.400 & 9.300 & 8.800 & 8,800 & 9,000 & 8,500 \\
\hline Gilmer & & 9,200 & 9.500 & 9.900 & 9.600 & 9,000 & 8,800 \\
\hline Grant & & 7,200 & 7.500 & 7,700 & 7.800 & 7,500 & 7,900 \\
\hline Green brier & & 34,900 & 32,600 & 33,600 & 34,500 & 34,500 & 35,800 \\
\hline Hampshire & & 10,900 & 10,600 & 10.400 & 10,100 & 9,700 & 10,200 \\
\hline Hancock & & 3.100 & 3.200 & 3.200 & 3,000 & 3,200 & 3,000 \\
\hline Hardy & & 11,800 & 11,800 & 11,300 & 10,100 & 9,600 & 10,300 \\
\hline Harrison & & 29,900 & 28,600 & 27,900 & 27,900 & 27,300 & 25,500 \\
\hline Jackson & & 31,200 & 30,900 & 31,800 & 32,500 & 32,700 & 34,100 \\
\hline Jefferson & & 40,000 & 42,100 & 44,800 & 45,900 & 46,200 & 48,400 \\
\hline Kanawha & & 13,500 & 13,600 & 13,400 & 12,800 & 12,200 & 12,800 \\
\hline Lewis & & 20.600 & 20,500 & 19,600 & 18,600 & 18,000 & 17,200 \\
\hline Lincolo & & 8.500 & 8,100 & 8,200 & 7,900 & 7,200 & 7,500 \\
\hline Logan & & 2.700 & 2,600 & 2,400 & 2,200 & 2,100 & 2,000 \\
\hline McDowell & & 3,900 & 4,000 & 3,600 & 3,700 & 3,600 & 3,200 \\
\hline Marion & & 11,700 & 11,200 & 10,700 & 10,100 & 9,400 & 9,000 \\
\hline Marshall & & 34,900 & 35,300 & 35,700 & 34,900 & 35,300 & 32,100 \\
\hline Masoo & & 46,600 & 48,900 & 49,500 & 48,000 & 47,900 & 46,200 \\
\hline Mercer & & 17,800 & 17,700 & 17,300 & 17,000 & 17,700 & 19,000 \\
\hline Mineral & & 8,600 & 8,500 & 7,700 & 7,100 & 7,400 & 7,700 \\
\hline Mingo & & 3,600 & 3,900 & 3,800 & 3,900 & 4,000 & 3,500 \\
\hline Mooongal ia & & 17,400 & 17,900 & 18,000 & 16,600 & 16,300 & 14,700 \\
\hline Monroe & & 28,600 & 29,200 & 30,300 & 31,300 & 32,000 & 33,300 \\
\hline Morgan & & 4,500 & 4,600 & 4,500 & 3,700 & 3,400 & 3,600 \\
\hline Nichalas & & 11,600 & 11,300 & 11,300 & $1.1,300$ & 10,700 & 11,700 \\
\hline Ohio & & 18,400 & 19,500 & 20,100 & 19,700 & 19,900 & 18,400 \\
\hline Pendleton & & 11,500 & 11,200 & 11,300 & 11,400 & 11,600 & 12,400 \\
\hline Pleasants & & 3.900 & 3,900 & 4,000 & 3,600 & 3,400 & 2,900 \\
\hline Pocahontas & & 12,500 & 12,100 & 11,900 & 11,600 & 11,200 & 11,100 \\
\hline Prestan & & 33,200 & 33,500 & 34,000 & 35,100 & 36,100 & 34,100 \\
\hline Putoam & & 14,500 & 14,800 & 14,800 & 13,500 & 13,000 & 13,500 \\
\hline Raleigh & & 11,300 & 11,000 & 10,400 & 9,500 & 9,100 & 8,100 \\
\hline Randolph & & 17,100 & 16,700 & 16,800 & 17,600 & 18,100 & 17,900 \\
\hline Ritchie & & 13,800 & 13,500 & 13,300 & 12,700 & 12,700 & 11,700 \\
\hline Roane & & 13,500 & 13,300 & 13,200 & 13,300 & 12,900 & 13,000 \\
\hline Summers & & 13,800 & 12.500 & 11,300 & 10,800 & 10,500 & 10,200 \\
\hline Taylor & & 8.800 & 8,900 & 8,800 & 8,900 & 9.200 & 7,600 \\
\hline Tucker & & 6,500 & 6.300 & 6,000 & 5,700 & 5,800 & 5,900 \\
\hline Tylet & & 12,000 & 11,600 & 11,800 & 11,800 & 12,000 & 10,400 \\
\hline Upshor & & 18,700 & 19,000 & 19,300 & 18,900 & 18,900 & 17,000 \\
\hline Wayne & & 14,600 & 14,700 & 14,300 & 13,600 & 13,100 & 12,200 \\
\hline Webster & & 5,300 & 5.500 & 5,800 & 5,800 & 5,400 & 8,200 \\
\hline Wetzel & & 13,900 & 14.100 & 13,700 & 12,700 & 11,900 & 12,500 \\
\hline Wirt & & 8,400 & 8,900 & 8,800 & 7,900 & 7,700 & 8,100 \\
\hline Waod & & 26.500 & 26,500 & 26,700 & 26,200 & 25,600 & 24,800 \\
\hline Wyoming & & 5,500 & 5,300 & 4,900 & 4,600 & 4,300 & 4,300 \\
\hline TOTAL & & 815,000 & 815,000 & 815,000 & 801,000 & 795,000 & 788,000 \\
\hline
\end{tabular}


Data presented in this table are based on the preceding table, Table 1A, Section VI.

\begin{tabular}{|c|c|c|c|c|c|c|c|}
\hline COUNTY & 1940 & 1954 & 1955 & 1956 & 1957 & 1958 & 1959 \\
\hline Barbour & & 100.0 & 92.4 & 21.8 & 90.5 & 89.9 & 84.2 \\
\hline Berkeley & & 100.0 & 106.7 & 107.3 & 108.0 & 110.4 & 116.9 \\
\hline Boone & & 100.0 & 90.5 & 90.5 & 81.0 & 71.4 & 76.2 \\
\hline Brexton & & 100.0 & 98.7 & 98.0 & 96.7 & 96.7 & 104.0 \\
\hline Brooke & & 100.0 & 98.2 & 103,6 & 103.6 & 98.2 & 101.8 \\
\hline Cabell & & 100.0 & 96.9 & 93.0 & 86.7 & 85.2 & 79.7 \\
\hline Calhouo & & 100.0 & 96.8 & 94.7 & 94.7 & 91.6 & 89.5 \\
\hline $\mathrm{Clay}$ & & 100.0 & 103.8 & 98.7 & 88.5 & 84.6 & 80.8 \\
\hline Doddridge & & 100.0 & 96.3 & 99.1 & 100,0 & 103,7 & 99,1 \\
\hline Fayette & & 100.0 & 98.9 & 93.6 & 93.6 & 95.7 & 90.4 \\
\hline Gilmer & & 100,0 & 103.3 & 107.6 & 104.3 & 97.8 & 95.7 \\
\hline Grant & & 100.0 & 104.2 & 106.9 & 108.3 & 104.2 & 109.7 \\
\hline Green brier & & 100.0 & 93.4 & 96.3 & 98.9 & 98,9 & 102,6 \\
\hline Hampshire & & 200.0 & 97.2 & 95.4 & 92.7 & 89.0 & 93,6 \\
\hline Hancock & & 100.0 & 103,2 & 103.2 & 96.8 & 103,2 & 96.8 \\
\hline Hardy & & 100.0 & 100.0 & 95.8 & 85.6 & 81.4 & 87.3 \\
\hline Harrisoo & & 100.0 & 95.7 & 93.3 & 93.3 & 91.3 & 85.3 \\
\hline Jackson & & 100.0 & 99.0 & 101.9 & 104.2 & 104.8 & 109.3 \\
\hline Jefferson & & 100.0 & 105.2 & 112,0 & 114.8 & 115.5 & 121.0 \\
\hline Kanawha & & 100.0 & 100.7 & 99,3 & 94.8 & 90.4 & 94.8 \\
\hline Lewia & & 100.0 & 99.5 & 95.1 & 90.3 & 87.4 & 83.5 \\
\hline Lincola & & 100.0 & 95.3 & 96.5 & 92.9 & 84.7 & 88.2 \\
\hline Logaa & & 100.0 & 96.3 & 88.9 & 81.5 & 77.8 & 74.1 \\
\hline McDawell & & 100,0 & 102.6 & 92.3 & 94.9 & 92,3 & 82.1 \\
\hline Marion & & 100.0 & 95.7 & 91.5 & 86.3 & 80.3 & 76.9 \\
\hline Marshall & & 100.0 & 101.1 & 102.3 & 100.0 & 101.1 & 92.0 \\
\hline Маasa & & 100.0 & 104.9 & 106.2 & 103.0 & 102.8 & 99.1 \\
\hline Mercet & & 100.0 & 99.4 & 97.2 & 95.5 & 99.4 & 106.7 \\
\hline Mineral & & 100.0 & 98.8 & 89.5 & 82.6 & 86.0 & 89.5 \\
\hline Mingo & & 100.0 & 108.3 & 105.6 & 108.3 & 111.1 & 97.2 \\
\hline Monongalia & & 100.0 & 102.9 & 103.4 & 95.4 & 93.7 & 84.5 \\
\hline Manroe & & 100.0 & 102.1 & 105.9 & 109.4 & 111.9 & 116.4 \\
\hline Morgao & & 200.0 & 102.2 & 100.0 & 82.2 & 75.6 & 80.0 \\
\hline Nicholas & & 100.0 & 97.4 & 97.4 & 97.4 & 92.2 & 100.9 \\
\hline Ohio & & 100.0 & 106.0 & 109.2 & 107.1 & 108.2 & 100.0 \\
\hline Pendleroo & & 100.0 & 97.4 & 98.3 & 99.1 & 100.9 & 107.8 \\
\hline Pleasants & & 100.0 & 100.0 & 102.6 & 92,3 & 87.2 & 74.4 \\
\hline Pocahoatas & & 100.0 & 96.8 & 95.2 & 92.8 & 89.6 & 88.8 \\
\hline Preatoo & & 100.0 & 100.9 & 102.4 & 105.7 & 108.7 & 102.7 \\
\hline Putaa mo & & 100.0 & 102.1 & 102.1 & 93.1 & 89.7 & 93.1 \\
\hline Raleigh & & 100,0 & 97.3 & 92.0 & 84.1 & 80.5 & 71.7 \\
\hline Randalph & & 100.0 & 97.7 & 98.2 & 102.9 & 105.8 & 104.7 \\
\hline Ritchie & & 100.0 & 97.8 & 96.4 & 92.0 & 92.0 & 84.8 \\
\hline Rosae & & 100.0 & 98.5 & 97.8 & 98.5 & 95.6 & 96.3 \\
\hline Summera & & 100.0 & 90.6 & 81.9 & 78.3 & 76.1 & 73,9 \\
\hline Taylor & & 100.0 & $101+1$ & 100.0 & 101.1 & 104.5 & 86.4 \\
\hline Tucker & & 100.0 & 96.9 & 92.3 & 87.7 & 89.2 & 90.8 \\
\hline Tyler & & 100.0 & 96.7 & 98.3 & 98.3 & 100.0 & 86.7 \\
\hline Upahur & & 100.0 & 101.6 & 103.2 & 101.1 & 101.1 & 90.9 \\
\hline Wayae & & 100.0 & 100.7 & 97.9 & 93.2 & 89.7 & 83.6 \\
\hline Webster & & 100.0 & 103.8 & 109.4 & 109.4 & 101.9 & 104.7 \\
\hline Wetzel & & 100.0 & 101.4 & 98.6 & 91.4 & 85.6 & 89.9 \\
\hline Wirt & & 100.0 & 106.0 & 104.8 & 94.0 & 91.7 & 96.4 \\
\hline Wood & & 100.0 & 100.0 & 100.8 & 98.9 & 96,6 & 936 \\
\hline Wyaming & & 100.0 & 96.4 & 89.1 & 83.6 & 78.2 & 78.2 \\
\hline TOTAL & & 100.0 & 100.0 & 100.0 & 98.3 & 97.5 & 96.7 \\
\hline
\end{tabular}

Section VI AGRICULTURE
W. Va, Unlv.

Agr. Exp. Sta. Bul. No. 464

Page 69 
Data presented in this table were taken from Agricultural Statistics, West Virginia - 1960, and earlier editions of this publication. Agricultural Statistics is published by the Agricultural Marketing Service of the United States Department of Agriculture and the West Virginia Department of Agriculture.

Section VI AGRICULTURE

W. Va. Univ. Agr. Exp. Sta. Bul. Na. 464

\begin{tabular}{|c|c|c|c|c|c|c|c|}
\hline COUNTY & 1940 & 1950 & 1955 & 1956 & 1957 & 1958 & 1959 \\
\hline Barbour & & 11.499 & 7,593 & 7,231 & 6,562 & 7,035 & 7.724 \\
\hline Berkeley & & 9,065 & 8,760 & 8,553 & 7,938 & 7,927 & 7,808 \\
\hline Boone & & 3,155 & 3,407 & 3,412 & 3,408 & 3,714 & 3,840 \\
\hline Braxtoo & & 14,846 & 10,402 & 10,480 & 9,815 & 10,427 & 10,560 \\
\hline Brooke & & 2,809 & 2,623 & 2,592 & 2,264 & 2,456 & 2.277 \\
\hline Cabell & & 11,206 & 8,922 & 9,378 & 9,452 & 10,249 & 9,860 \\
\hline Calhnun & & 7,072 & 5,042 & 4,794 & 4,211 & 4,213 & 4,438 \\
\hline Clay & & 7.677 & 4,375 & 4,153 & 4.039 & 4,524 & 4,203 \\
\hline Doddridge & & 5,880 & 4,205 & 4,217 & 4,112 & 4,337 & 4,202 \\
\hline Fayette & & 10,378 & 8,764 & 8,804 & 8,509 & 8,529 & 9,146 \\
\hline Gilmer & & 6,602 & 5,410 & 5,017 & 4,650 & 5.113 & 5.070 \\
\hline Grant & & 9.432 & 5.698 & 5,407 & 4,863 & 4,916 & 5,183 \\
\hline Green brier & & 17,074 & 12,878 & 12,365 & 11,702 & 12,902 & 13,607 \\
\hline Hampshire & & 14,716 & 10,047 & 10,501 & 10,291 & 9,872 & 9,302 \\
\hline Haacock & & 2,259 & 1,983 & 2,018 & 1,947 & 1,908 & 1,789 \\
\hline Hardy & & 13,871 & 10,038 & 9,949 & 9,415 & 9,806 & 10,122 \\
\hline Harrisoo & & 14,541 & 10,329 & 10,902 & 10,976 & 11,544 & 12,700 \\
\hline Jackson & & 22,059 & 12,739 & 12,010 & 10,442 & 10,202 & 10,722 \\
\hline Jefferson & & 5,320 & 4,164 & 3,797 & 3,238 & 3,155 & 3,395 \\
\hline Kanawha & & 14,047 & 9,192 & 9,206 & 8,783 & 8,776 & 8,623 \\
\hline Lewis & & 9,071 & 6,523 & 6,673 & 6,331 & 6,672 & 7,198 \\
\hline Lincolo & & 10,852 & 6,726 & 6,584 & 6.078 & 5,883 & 6,456 \\
\hline Logan & & 5,412 & 3,196 & 3,103 & 3,038 & 2,919 & 2,715 \\
\hline McDowell & & 4,973 & 3,221 & 3,070 & 3,010 & 2,961 & 2,616 \\
\hline Marion & & 10,934 & 6,861 & 6,970 & 6,796 & 7,276 & 7,772 \\
\hline Marsball & & 10,276 & 8,808 & 8,985 & 8,112 & 8,024 & 8,135 \\
\hline Ma son & & 14,879 & 10,817 & 10,962 & 10,585 & 11,344 & 11,391 \\
\hline Mercer & & 12,347 & 10,721 & 11,060 & 10,378 & 10,348 & 11,153 \\
\hline Mineral & & 5,221 & 4,365 & 4.512 & 4,645 & 4.916 & 4.711 \\
\hline Miogo & & 5,228 & 4,096 & 4.222 & 3,999 & 3,779 & 3,411 \\
\hline Monongalia & & 10.114 & 8.934 & 8.549 & 7,951 & 8.482 & 8,850 \\
\hline Monroe & & 14.198 & 11.887 & 11.413 & 10,386 & 9.512 & 9.424 \\
\hline Morgao & & 9.343 & 6.838 & 6.697 & 6,389 & 6.313 & 6,288 \\
\hline Nicholas & & 11,311 & 9.164 & 9,015 & 8,502 & 8,339 & 9.072 \\
\hline Ohio & & 4,462 & 4,864 & 4.907 & 4,439 & 4.224 & 3.797 \\
\hline Pendletoo & & 14,068 & 10,167 & 9.821 & 9.212 & 9,545 & 9,372 \\
\hline Pleasaats & & 2,299 & 1.702 & 1,671 & 1,667 & 1,590 & 1.478 \\
\hline Pncabontas & & 5,953 & 5,307 & 5,004 & 4,345 & 4,414 & 4.527 \\
\hline Preston & & 16.782 & 15.744 & 15,057 & 13,571 & 14,303 & 15,662 \\
\hline Poenam & & 12,037 & 7.712 & 7,760 & 7,104 & 7.206 & 7.571 \\
\hline Raleigh & & 11,303 & 10,493 & 10.540 & 10,612 & 10,469 & 10.761 \\
\hline Randolph & & 9.106 & 7,770 & 7,400 & .6452 & 6.492 & 6.669 \\
\hline Ritchie & & 7,529 & 4,779 & 4.487 & 3,895 & 3.661 & 3,493 \\
\hline Roaoe & & 16,347 & 10.753 & 11.135 & 10,531 & 11.265 & 11.228 \\
\hline Summers & & 10,700 & 8,853 & 9,050 & 7,891 & 7,046 & 5,953 \\
\hline Taylor & & 4,237 & 3,896 & 3.984 & 3,644 & 4,058 & 3,892 \\
\hline Tucker & & 3,631 & 3,158 & 3,080 & 2,649 & 2,399 & 2,380 \\
\hline Tyler & & 5,003 & 3,430 & 3,269 & 2,777 & 2,784 & 2,842 \\
\hline Upshur & & 9,115 & 7,090 & 7,312 & 7,362 & 7,697 & 8,567 \\
\hline Wayoe & & 14,508 & 11,418 & 11,140 & 9,947 & 9,198 & 8,999 \\
\hline Webstex & & 5,880 & 4,577 & 4,232 & 3,912 & 3,574 & 3,774 \\
\hline Wetzel & & 7,598 & 6,654 & 6,785 & 6,069 & 5,613 & 5,323 \\
\hline Wirt & & 7,582 & 4,496 & 4,376 & 3,823 & 3,741 & 3,224 \\
\hline Wood & & 14,629 & 11.645 & 11.611 & 11,005 & 12,208 & 12,376 \\
\hline Wynming & & 5,564 & 4,764 & 4.778 & 4,276 & 4,142 & 4.338 \\
\hline TOTAL & & 526,000 & 398,000 & 394.000 & 368.000 & 374,000 & 380,000 \\
\hline
\end{tabular}


TABLE 2B. INDEX OF TOTAL EGG PRODUCTION FOR THE COUNTIES OF WEST VIRGINIA FOR SPECIFIED YEARS, $1950=100$

Data presented in this table is based on data presented in the preceding table, Table $2 \mathrm{~A}$, Section VI.

\begin{tabular}{|c|c|c|c|c|c|c|c|}
\hline COUNTY & 1940 & 1950 & 1955 & 1956 & 1957 & 1958 & 1959 \\
\hline Barbour & & 100.00 & 66.0 & 62.9 & 57.1 & 61.2 & 67.2 \\
\hline Berkeley & & 100.0 & 96.6 & 94.4 & 87.6 & 87.4 & 86.1 \\
\hline Boone & & 100,0 & 108.0 & 108.1 & 108.0 & 117.7 & 121.7 \\
\hline Braxton & & 100.0 & 70.1 & 70.6 & 66,1 & 70.2 & 71.1 \\
\hline Brooke & & 100.0 & 93.4 & 92.3 & 80.6 & 87.4 & 81.1 \\
\hline Cabell & & 100.0 & 79.6 & 83.7 & 84.3 & 91.4 & 88.0 \\
\hline Calhoun & & 100.0 & 71.3 & 67.8 & 59.5 & 59.6 & 62.8 \\
\hline Clay & & 100.0 & 57.0 & 54.1 & 52.6 & 58.9 & 54.7 \\
\hline Doddridge & & 100,0 & 71.5 & 71.7 & 69.9 & 73.8 & 71.5 \\
\hline Fayetre & & 100,0 & 84.4 & 84.8 & 82.0 & 82.2 & 88.1 \\
\hline Gilmer & & 100.0 & 81.9 & 76.0 & 70.4 & 77.4 & 76.8 \\
\hline Grant & & 100.0 & 60.4 & 57.3 & 51.6 & 52.1 & 55.0 \\
\hline Greenbrier & & 100,0 & 75.4 & 72.4 & 68.5 & 75.6 & 79.7 \\
\hline Hampshire & & 100,0 & 68.3 & 71.4 & 69.9 & 67.1 & 63.2 \\
\hline Hancock & & 100.0 & 87.8 & 89.3 & 86.2 & 84.5 & 79.2 \\
\hline Hardy & & 100.0 & 72.4 & 71.7 & 67.9 & 70.7 & 73.0 \\
\hline Harrison & & 100.0 & 71.0 & 75.0 & 75.5 & 79.4 & 87.4 \\
\hline Jackson & & 100.0 & 57.7 & 54.4 & 47.3 & 46.2 & 48.6 \\
\hline Jefferson & & 100.0 & 78.3 & 71.4 & 60.9 & 59.3 & 63.8 \\
\hline Kanawha & & 100.0 & 65.4 & 65.5 & 62,5 & 62.5 & 61.4 \\
\hline Lewis & & 100.0 & 71.9 & 73.6 & 69.8 & 73.6 & 79.4 \\
\hline Lincola & & 100.0 & 62.0 & 60.7 & 56.0 & 54.2 & 59.5 \\
\hline Logan & & 100.0 & 59.0 & 57.3 & 56,1 & 53.9 & 50.2 \\
\hline McDowell & & 100.0 & 64.8 & 61.7 & 60.5 & 59.5 & 52.6 \\
\hline Mation & & 100.0 & 62.7 & 63.7 & 62.2 & 66.5 & 71.1 \\
\hline Marshall & & 100.0 & 85.7 & 87.4 & 78.9 & 78.1 & 79.2 \\
\hline Mason & & 100.0 & 72.7 & 73.7 & 71.1 & 76.2 & 76.6 \\
\hline Mercer & & 100.0 & 86.8 & 89.6 & 84.0 & 83.8 & 90.3 \\
\hline Mineral & & 100.0 & 83.6 & 86.4 & 89.0 & 94.2 & 90.2 \\
\hline Mingo & & 100.0 & 78.3 & 80.8 & 76.5 & 72.3 & 65.2 \\
\hline Mooongalia & & 100.0 & 88.3 & 84.5 & 78.6 & 83.9 & 87.5 \\
\hline Monroe & & 100,0 & 83.7 & 80.4 & 73.2 & 67.0 & 66.4 \\
\hline Morgan & & 100.0 & 73.2 & 71.7 & 68.4 & 67.6 & 67.3 \\
\hline Nicholas & & 100.0 & 81.0 & 79.7 & 75.2 & 73.7 & 80.2 \\
\hline Ohio & & 100.0 & 109.0 & 110.0 & 99.5 & 94.7 & 85.1 \\
\hline Pendleton & & 100.0 & 72.3 & 69.8 & 65.5 & 67.8 & 66.6 \\
\hline Pleasants & & 100.0 & 74.0 & 72.7 & 72.5 & 69.2 & 64.3 \\
\hline Pocahontas & & 100.0 & 89.1 & 84.0 & 73.0 & 74.1 & 76.0 \\
\hline Prestoo & & 100.0 & 93.8 & 89.7 & 80.9 & 85.2 & 93.3 \\
\hline Putnam & & 100.0 & 64.1 & 64.5 & 59.0 & 59.9 & 62.9 \\
\hline Raleigh & & 100.0 & 92.8 & 93.2 & 93.9 & 92.6 & 95.2 \\
\hline Randolph & & 100.0 & 85.3 & 81.3 & 70.8 & 71.3 & 73.2 \\
\hline Ritchie & & 100,0 & 63.5 & 59.6 & 51.7 & 48.6 & 46.4 \\
\hline Roane & & 100.0 & 65.8 & 68.1 & 64.4 & 68.9 & 68.7 \\
\hline Summers & & 100,0 & 82.7 & 84.6 & 73.7 & 65.8 & 55.6 \\
\hline Taylor & & 100,0 & 92.0 & 94.0 & 86.0 & 95.8 & 91.8 \\
\hline Tucker & & 100.0 & 87.0 & 84.8 & 73.0 & 66.1 & 65.5 \\
\hline Tylet & & 100.0 & 68.6 & 65.3 & 55.5 & 55.6 & 56.8 \\
\hline Upshat & & 100.0 & 77.8 & 80.2 & 80.8 & 84.4 & 94.0 \\
\hline Wayne & & 100.0 & 78.7 & 76.8 & 68.6 & 63.4 & 62.0 \\
\hline Webster & & 100.0 & 77.8 & 72.0 & 66.5 & 60.8 & 64.2 \\
\hline Wetzel & & 100.0 & 87.6 & 89,3 & 79,9 & 73.9 & 70.0 \\
\hline Wirt & & 100.0 & 59.3 & 57.7 & 50.4 & 49.3 & 42.5 \\
\hline Food & & 100.0 & 79.6 & 79.4 & 75.2 & 83.4 & 84.6 \\
\hline Wyoming & & 100.0 & 85.6 & 85.9 & 76.8 & 74.4 & 78.0 \\
\hline TOTAL & & 100.0 & 75.7 & 74.9 & 70.0 & 71.1 & 72.2 \\
\hline
\end{tabular}

Section VI AGRICULTURE

W. Va. Univ.

Agr. Exp. Sta.

Bul. No. 464

Page 71 



\section{Section VII \\ TRANSPORTATION AND ROADS}

Table

1A The Total Number of Vehicles Registered by the Department of Motor Vehicles of the State of West Virginia for the Counties of West Virginia $\ldots$.

Index of the Total Number of Vehicles Registered by the Department of Motor Vehicles of the State of West Virginia for the Counties of West Virginia, $1955=100 \quad \ldots$.

2A The Ratio of the Number of Automobiles to the Number of Trucks Owned for Personal or Firm Use (Trucks Not For Hire Commercially) for the Counties of West Virginia ....

Index of the Ratio of the Number of Automobiles to the Number of Trucks Owned for Personal or Firm Use (Trucks Not for Hire Commercially) for the Counties of West Virginia, $1950=100$

Total Miles of Roads (All Types) in the Counties of West Virginia

The Percentages of Total Mileage in Roads Classified as "High Type" Roads for the Counties of West Virginia ...

Index of the Number of Miles of "High Type" Roads in the Counties of West Virginia, $1950=100 \ldots$.

The Number of Persons per Mile of "High Type" Roads for the Counties of West Virginia .....

$4 \mathrm{~B}$ Index of the Number of Persons per Mile of "High Type" Roads for the Counties of West Virginia, $1950=100 \ldots \ldots$

$5 A$ The Number of Miles of "High Type" Roads per 100 Square Miles of Area for the Counties of West Virginia .... 
TABLE IA. THE TOTAL NUMBER OF VEHICLES REGISTERED BY THE

DEPARTMENT OF MOTOR VEHICLES OF THE STATE OF WEST VIRGINIA FOR THE COUNTIES OF WEST VIRGINIA

Data presented in this table are based on the annual reports

of the Department of Motor Vehicles of the State of West Virginia.

Section VII

TRANSPORTATION

AND ROADS

W. Vo. Univ.

Agr. Exp. Sta.

Bul. Na. 464

Page 74




TABLE IB. INDEX OF THE TOTAL NUMBER OF VEHICLES REGISTERED BY THE DEPARTMENT OF MOTOR VEHICLES OF THE STATE OF WEST VIRGINIA FOR THE COUNTIES OF WEST VIRGINIA, $1955=100$

The information presented in this table is based upon the data presented in the preceding table, Table 1A, Section VII.

\begin{tabular}{|c|c|c|c|c|c|c|c|}
\hline COUNTY & 1955 & 1956 & 1957 & 1958 & 1959 & 1960 & \\
\hline Barbour & 100.0 & 98.5 & 101.9 & 102.0 & 106.5 & 106.1 & \\
\hline Berkeley & 100.0 & 103.6 & 107.6 & 106.3 & 109.2 & 111.8 & \\
\hline Boone & 100.0 & 106.9 & 117.4 & 116.2 & 113.3 & 108.5 & \\
\hline Braxton & 100.0 & 99.9 & 108.3 & 111.9 & 115.8 & 111.2 & \\
\hline Brooke & 100.0 & 117.1 & 119.2 & 125.3 & 130.3 & 133.6 & \\
\hline Cabell & 100.0 & 74.1 & 106.2 & 108.3 & 107.5 & 109.7 & \\
\hline Calhoun & 100.0 & 120.7 & 102.7 & 115.9 & 114.3 & 112.1 & \\
\hline Clay & 100.0 & 104.1 & 111.5 & 106.4 & 110.8 & 106.4 & \\
\hline Doddridge & 100.0 & 96.8 & 100.6 & 109.3 & 106.4 & 102.0 & \\
\hline Fayecte & 100.0 & 101.1 & 105.9 & 109.2 & 107.8 & 101.6 & \\
\hline Gilmer & 100.0 & 100.8 & 105.5 & 110.3 & 116.2 & 117.8 & \\
\hline Grant & 100.0 & 106.6 & 106.1 & 107.6 & 112.9 & 113.1 & \\
\hline Greeobrier & 100.0 & 101.8 & 106.2 & 109.9 & 111.2 & 108.9 & \\
\hline Hampshire & 100.0 & 73.7 & 100.2 & 105.7 & 105.8 & 105.3 & \\
\hline Hancock & 100.0 & 106.5 & 111.0 & 110.6 & 113.1 & 116.4 & \\
\hline Hardy & 100.0 & 105.3 & 104.5 & 105.7 & 112.0 & 111.4 & \\
\hline Harrison & 100.0 & 103.6 & 110.7 & 111.8 & 112,0 & 110.1 & \\
\hline Jacksoo & 100.0 & 105.5 & 122.1 & 139.4 & 140.5 & 150.8 & \\
\hline Jefferson & 100.0 & 105.5 & 105.1 & 107.5 & 111.2 & 108.1 & \\
\hline Kanawha & 100.0 & 101,4 & 106.7 & 110.5 & 112.7 & -115.1 & \\
\hline Lewis & 100.0 & 106.2 & 106.1 & 107.6 & 108.8 & 102.8 & \\
\hline Lincoln & 100.0 & 106.2 & 112.7 & 123.6 & 117.6 & 115.0 & \\
\hline Logan & 100,0 & 107.4 & 112.1 & 116.6 & 111.5 & 106.4 & \\
\hline McDowell & 100.0 & 103.8 & 106.8 & 107.0 & 101.1 & 97.3 & \\
\hline Marion & 100.0 & 101.4 & 106.3 & 111.3 & 113.1 & 111.6 & \\
\hline Marshall & 100.0 & 113.1 & 110.1 & 117.2 & 119.7 & 119.0 & \\
\hline Mason & 100.0 & 107.7 & 107.1 & 115.3 & 120.9 & 121.3 & - \\
\hline Mercer & 100.0 & 104.5 & 111.1 & 114.8 & 114.9 & 114.4 & \\
\hline Mineral & 100.0 & 101.0 & 104.4 & 108.6 & 111.7 & 118.3 & \\
\hline Mingo & 100.0 & 108.3 & 114.3 & 118.3 & 113.7 & 104.2 & \\
\hline Monongalia & 100.0 & 103.4 & 109.1 & 111.1 & 110.3 & 107.8 & \\
\hline Moorne & 100,0 & 84.2 & 89.3 & 89.8 & 94.3 & 95.9 & \\
\hline Morgan & 100.0 & 100.5 & 101.8 & 105.7 & 106.0 & 103.5 & \\
\hline Nicholas & 100.0 & 119.8 & 130.0 & 137.1 & 136.4 & 132.3 & \\
\hline Ohio & 100.0 & 107.0 & 109.2 & 110.8 & 109.9 & 109.8 & \\
\hline Pendleton & 100.0 & 100.2 & 102.7 & 104.0 & 107.5 & 106.5 & \\
\hline Pleasants & 100.0 & 99.7 & 106.1 & 114.2 & 116.5 & 139.3 & \\
\hline Pocahootas & 100.0 & 101.6 & 104.7 & 108.5 & 112.6 & 111.3 & \\
\hline Preston & 100,0 & 99.7 & 106.7 & 109.5 & 109.2 & 102.4 & \\
\hline Putnam & 100.0 & 98.0 & 111.3 & 117.5 & 120.5 & 122.7 & \\
\hline Raleigh & 100.0 & 101.0 & 111.1 & 117.3 & 115.5 & 112.7 & \\
\hline Randolph & 100.0 & 101.8 & 103.2 & 104.8 & 109.7 & 107.5 & \\
\hline Ritchie & 100.0 & 100.7 & 103.4 & 105.9 & 107.7 & 105.8 & \\
\hline Roane & 100.0 & 95.4 & 103.0 & 110.5 & 113.7 & 114.0 & \\
\hline Summers & 100.0 & 101.4 & 107.3 & 112.9 & 110.8 & 108.9 & \\
\hline Taylor & 100.0 & 99.6 & 101.9 & 104.3 & 106.9 & 103.2 & \\
\hline Tucker & 100.0 & 104.3 & 101.6 & 106.2 & 109.6 & 110.4 & \\
\hline Tylez & 100.0 & 71.7 & 104.5 & 111.7 & 116.6 & 111.0 & \\
\hline Upshur & 100.0 & 78.2 & 80.8 & 83.7 & 86.2 & 84.0 & \\
\hline Wayoe & 100.0 & 104.2 & 107.8 & 115.1 & 120.3 & 123.4 & \\
\hline Webster & 100.0 & 102.9 & 108.4 & 112.4 & 112.4 & 105.2 & \\
\hline Weızel & 100.0 & 103.7 & 111.0 & 117.7 & 121.1 & 127.7 & \\
\hline Wirt & 100.0 & 106.5 & 117.5 & 134.7 & 129.7 & 124.9 & \\
\hline Food & & 105.4 & 112.2 & 118.8 & 123.1 & 125.2 & \\
\hline Wyoming & 100.0 & 105.0 & 114.1 & 116.7 & 114.2 & 111.6 & \\
\hline TOTAL & 100.0 & 102.8 & 108.2 & 111.8 & 112.6 & 112.0 & \\
\hline
\end{tabular}

Section VII

TRANSPORTATION AND ROADS

W. Va. Univ. Agr. Exp. Sta. Bul. No. 464

Page 75 


\section{TABLE 2A. THE RATIO OF THE NUMBER OF AUTOMOBILES TO THE NUMBER OF TRUCKS OWNED FOR PERSONAL OR FIRM USE (TRUCKS NOT FOR HIRE COMMERCIALLY) FOR THE COUNTIES OF WEST VIRGINIA}

Data presented in this table are based upon the annul reports

of the Department of Motor Vehicles of the State of West Virginia.

Section VII

TRANSPORTATION AND ROADS

W. Ya. Univ.

Agr. Exp. Sto. Bul. No. 464

Page 76

\begin{tabular}{|c|c|c|c|c|c|c|c|}
\hline COUNTY & 1950 & 1955 & 1956 & 1957 & 1958 & 1959 & 1960 \\
\hline Barbour & 2.90 & 2.67 & 3.08 & 2.83 & 3.13 & 2.89 & 2.88 \\
\hline Berkeley & 3.97 & 4.41 & 4.82 & 4.71 & 4.60 & 4.53 & 4.91 \\
\hline Boone & 3.11 & 3.19 & 3.47 & 3.04 & 3.75 & 3.83 & 3.97 \\
\hline Braxton & 1.73 & 1.78 & 1.93 & 2.10 & 2.15 & 2.09 & 2.02 \\
\hline Brooke & 3.72 & 5.06 & 5.94 & 5.79 & 6.01 & 5.95 & 5.93 \\
\hline Cabell & 4.01 & 5.31 & 5.64 & 5.88 & 6.02 & 5.89 & 5.98 \\
\hline Calhoun & 2.28 & 2.29 & 2.39 & 2.31 & 2.04 & 2.42 & 2.22 \\
\hline Clay & 2,21 & 2.19 & 2.20 & 2.25 & 2.91 & 2.29 & 2.18 \\
\hline Doddridge & 3.21 & 3.00 & 3.48 & 3.34 & 2.45 & 3.22 & 3.03 \\
\hline Fayette & 3.57 & 3.88 & 4.05 & 4.12 & 4.27 & 4.19 & 4.23 \\
\hline Gilmer & 2.65 & 2.41 & 2.38 & 2.49 & 2.59 & 2.53 & 2.55 \\
\hline Grant & -1.84 & 2.19 & 1.98 & 2.20 & 2.29 & 2.22 & 2.38 \\
\hline Greeabrier & 2.36 & 2.70 & 2.74 & 2.65 & 2.75 & 2.64 & 2.74 \\
\hline Hampshire & 1.81 & 1.72 & 1.42 & 2.21 & 2.17 & 2.42 & 2.50 \\
\hline Hancock & 5.35 & 5.73 & 6.23 & 6.19 & 6.47 & 6.35 & 6.57 \\
\hline Hardy & 2.01 & 2.42 & .2 .33 & 2.22 & 2.20 & 2.18 & 2.37 \\
\hline Harrison & 3.62 & 4.34 & 4.45 & 4.66 & 4.57 & 4.63 & 4.54 \\
\hline Jackson & 1.81 & 1.89 & 2.07 & 2.30 & 2.68 & 2.77 & 3.10 \\
\hline Jefferson & 3.92 & 4.70 & 4.43 & 4.27 & 4.44 & 4.23 & 4.31 \\
\hline Kanawha & 3.68 & 4.72 & 5.05 & 5.19 & 5.40 & 5.54 & 5.62 \\
\hline Lewis & 3.07 & 3.24 & 3.71 & 3.57 & 3.47 & 3.44 & 3.40 \\
\hline Lincola & 1.40 & 1.54 & 1.93 & 2.05 & 2.26 & 2.15 & 2.13 \\
\hline Logao & 4.52 & 3.67 & 3.62 & 3.75 & 4.02 & 3.83 & 3.85 \\
\hline McDowell & 3.53 & 3.82 & 3.90 & 3.86 & 3.93 & 3.88 & 3.84 \\
\hline Marion & 4.04 & 4.56 & 4.86 & 4.88 & 4.81 & 4.72 & 4.77 \\
\hline Marshall & 4.48 & 6.23 & 6.49 & 5.78 & 5.43 & 5.85 & 5.64 \\
\hline Ma son & 2.08 & 3.36 & 3.77 & 3.87 & 4.10 & 4.17 & 4.38 \\
\hline Mercer & 3.06 & 3.58 & 3.85 & 3.94 & 4.09 & 4.06 & 4.15 \\
\hline Mineral & 3.27 & 4.41 & 4.86 & 4.80 & 5.30 & 4.46 & 4.78 \\
\hline Miogo & 2.24 & 2.71 & 2.99 & 3.01 & 3.14 & 3.14 & 3.36 \\
\hline Mooongalia & 3.99 & 4.29 & 4.67 & 4.71 & 4.91 & 4.79 & $4 . \overline{86}$ \\
\hline Mootoe & 2.00 & 1.81 & 2.09 & 2.24 & 2.23 & 2.34 & 2.43 \\
\hline Morgao & 3.54 & 3.90 & 4.14 & 4.23 & 4.22 & 4.19 & 4.11 \\
\hline Nicholas & 2.20 & 4.64 & 2.48 & 2.53 & 2.60 & 2.48 & 2.49 \\
\hline Ohio & 4.44 & 5.82 & 5.68 & 4.72 & 6.71 & 6.70 & 6.61 \\
\hline Peodletoo & 1.84 & 1.83 & 1.81 & 1.74 & 1.77 & 1.78 & 2.01 \\
\hline Pleasaots & 3.01 & 3.67 & 3.91 & 3.62 & 4.03 & 3.92 & 1.82 \\
\hline Pocahootas & 2,41 & 2.36 & 2,41 & 2.36 & 2.32 & 2.32 & 2.37 \\
\hline Preston & 2.66 & 2.71 & 3.14 & 2.83 & 2.82 & 2.72 & 3,40 \\
\hline Putoam & 1.25 & 3.18 & 4.45 & 3.59 & 3.34 & 3.82 & 3.99 \\
\hline Raleigh & 3.09 & 3.40 & 3.50 & 3.82 & 3.97 & 3.95 & 3.95 \\
\hline Randolph & -1.69 & 2.75 & 3.15 & 3.05 & 2.98 & 3.06 & 2.95 \\
\hline Ritchie & 2.86 & 2.98 & 3.12 & 2.96 & 3.05 & 3.03 & 3.02 \\
\hline Roace & 2.18 & 2.68 & 2.47 & 2.52 & 2.80 & 2.80 & 2.83 \\
\hline Snmmers & 2.13 & 2.64 & 2.51 & 2.6 .5 & 2.83 & 2.65 & 2.61 \\
\hline Taylor & 4.10 & 4.16 & 4.17 & 4.30 & 4.31 & 4.00 & 3.91 \\
\hline Tucker & 3.44 & 2.87 & 2.39 & 3.00 & 3.04 & 2.93 & 2.55 \\
\hline Tyler & 4.04 & 4.23 & 4.26 & 4.36 & 4.36 & 4.51 & 4.02 \\
\hline Upshur & 2.65 & 1.27 & 3.20 & 3.15 & 3.13 & 3.14 & 3.09 \\
\hline Wayoe & 1.95 & 2.73 & 3.04 & 3.22 & 3.40 & 3.43 & 3.54 \\
\hline Webster & 2.55 & 2.29 & 2.33 & 2.34 & 2.39 & 2.38 & 2.34 \\
\hline Wetzel & 3.80 & 4.09 & 4.24 & 4.22 & 4.37 & 4.40 & 4.26 \\
\hline Wirt & 2.83 & 2.23 & 2.33 & 2.46 & 2.76 & 2.68 & 3.52 \\
\hline Wood & 4.26 & 5.53 & 3.92 & 6.05 & 6.17 & 6.07 & 5.67 \\
\hline Wyoming & 3.16 & 3.45 & 3.46 & 3.62 & 3.78 & 3.72 & 3.61 \\
\hline TOTAL & 3.27 & 3.75 & 3.99 & 4.01 & 4.17 & 4.15 & 4.19 \\
\hline
\end{tabular}


TABLE 2B. INDEX OF THE RATIO OF THE NUMBER OF AUTOMOBILES TO THE NUMBER OF TRUCKS OWNED FOR PERSONAL OR FIRM USE (TRUCKS NOT FOR HIRE COMMERICALLY) FOR THE COUNTIES OF WEST VIRGINIA

$$
1950=100
$$

The information contained in this table is based on data presented in the previons table, Table 2A, Section VIl.

\begin{tabular}{|c|c|c|c|c|c|c|c|}
\hline COUNTY & 1950 & 1955 & 1956 & 1957 & 1958 & 1959 & 1960 \\
\hline Barbour & 100.0 & 92.1 & 106.2 & 97.6 & 107.9 & 99.7 & 99.3 \\
\hline Berkeley & 100.0 & 111.1 & 121.4 & 118.6 & 115,9 & 114.1 & 123.7 \\
\hline Bonne & 100.0 & 102.6 & 111.6 & 97.7 & 120.6 & 123.2 & 127.7 \\
\hline Braxton & 100.0 & 102,9 & 111,6 & 121.4 & 124.3 & 120.8 & 116.8 \\
\hline Brooke & 100.0 & 136.0 & 159.7 & 155.6 & 161.6 & 159.9 & 159.4 \\
\hline Cabell & 100.0 & 132.4 & 140.6 & 146.6 & 150.1 & 146.9 & 149.1 \\
\hline Calhoun & 100.0 & 100.4 & 104.8 & 101.3 & 89.5 & 106.1 & 97.4 \\
\hline Clay & 100.0 & 99.1 & 99.5 & 101.8 & 131,7 & 103.6 & 98,6 \\
\hline Doddridge & 100.0 & 93.5 & 108.4 & 104.0 & 76.3 & 100.3 & 94.4 \\
\hline Fayecte & 100.0 & 108.7 & 113.4 & 115.4 & 119.6 & 117.4 & 118.5 \\
\hline Gilmer & 100.0 & 90.9 & 89.8 & 94.0 & 97.7 & 95.5 & 96.2 \\
\hline Grant & 100.0 & 119.0 & 107.6 & 119.6 & 124.5 & 120.7 & 129.3 \\
\hline Greenbrier & 100.0 & 114.4 & 116.1 & 112.3 & 116.5 & 111.9 & 116.1 \\
\hline Hampshire & 100.0 & 95.0 & 78.5 & 122.1 & 119.9 & 133.7 & 138.1 \\
\hline Hancock & 100.0 & 107.1 & 116.4 & 115.7 & 120.9 & 118.7 & 122.8 \\
\hline Hardy & 100.0 & 120.4 & 115.9 & 110.4 & 109.5 & 108.5 & 117.9 \\
\hline Harrison & 100.0 & 119.9 & 122.9 & 128.7 & 126.2 & 127.9 & 125.4 \\
\hline Jackson & 100.0 & 104.4 & 114.4 & 127.1 & 148.1 & 153.0 & 171.3 \\
\hline Jefferson & 100.0 & 119.9 & 113.0 & 108.9 & 113.3 & 107.9 & 109.9 \\
\hline Kanawha & 100.0 & 128.3 & 137.2 & 141.0 & 146.7 & 150.5 & 152.7 \\
\hline Lewis & 100.0 & 105.5 & 120.8 & 116.3 & 113.0 & 112.1 & 110.7 \\
\hline Lincoln & 100.0 & 110.0 & 137.9 & 146.4 & 161.4 & 153.6 & 152.1 \\
\hline Logan & 100.0 & 81.2 & 80.1 & 83.0 & 88.9 & 84.7 & 85.2 \\
\hline McDowell & 100,0 & 108.2 & 110.5 & 109.3 & 111.3 & 109.9 & 108.8 \\
\hline Marion & 100.0 & 112.9 & 120.3 & 120.8 & 119.1 & 116.8 & 118.1 \\
\hline Marshall & 100,0 & 139.1 & 144.9 & 129.0 & 121.2 & 130.6 & 125.9 \\
\hline Ma spn & 100.0 & 161.5 & 181.2 & 186.1 & 197.1 & 200.5 & 210.6 \\
\hline Mercer & 100.0 & 117.0 & 125.8 & 128.8 & 133.7 & 132.7 & 135.6 \\
\hline Mineral & 100,0 & 134,9 & 148.6 & 146.8 & 162.1 & 136.4 & 146.2 \\
\hline Mingo & 100.0 & 121.0 & 133.5 & 134.4 & 140.2 & 140.2 & 150.0 \\
\hline Monongalia & 100,0 & 107.5 & 117.0 & 118.0 & 123.1 & 120.0 & 121.8 \\
\hline Monroe & 100.0 & 90.5 & 104.5 & 112.0 & 111.5 & 117.0 & 121.0 \\
\hline Morgan & 100.0 & 110.2 & 116.9 & 119.5 & 119.2 & 118.4 & 116.1 \\
\hline Nicholes & 100,0 & 210.9 & 112.7 & 115.0 & 118.2 & 112.7 & 113.2 \\
\hline Ohin & 100.0 & 131.1 & 127.9 & 106.3 & 151.1 & 150.9 & 148.9 \\
\hline Pendletnn & 100.0 & 99.5 & 98.4 & 94.6 & 96.2 & 96.7 & 109.2 \\
\hline Plea sants & 100.0 & 121.9 & 129.9 & 120.3 & 133.9 & 130.2 & 60.5 \\
\hline Pocahontas & 100.0 & 97.9 & 100.0 & 97.9 & 96.3 & 96.3 & 98.3 \\
\hline Preston & 100.0 & 101.9 & 118.0 & 106.4 & 106.0 & 102.3 & 127.8 \\
\hline Putnam & 100.0 & 163.1 & 228.2 & 184.1 & 171.3 & 195.9 & 204.6 \\
\hline Raleigh & 100.0 & 110.0 & 113.3 & 123.6 & 128.5 & 127.8 & 127.8 \\
\hline Randolph & 100,0 & 162.7 & 186.4 & 180.5 & 176.3 & 181.1 & 174.6 \\
\hline Ritchie & 100.0 & 104.2 & 109.1 & 103.5 & 106.6 & 105.9 & 105.6 \\
\hline Roane & 100.0 & 122.9 & 113.3 & 115.6 & 128.4 & 128.4 & 129.8 \\
\hline Summers & 100.0 & 123.9 & 117.8 & 124.4 & 132,9 & 124.4 & 122.5 \\
\hline Taylor & 100.0 & 101.5 & 101.7 & 104.9 & 105.1 & 97.6 & 95.4 \\
\hline Tucker & 100.0 & 83.4 & 69.5 & 87.2 & 88.4 & 85.2 & 74.1 \\
\hline Tyler & 100,0 & 104.7 & 105.4 & 107.9 & 107.9 & 111.6 & 99.5 \\
\hline Upshur & 100.0 & 47.2 & 120.8 & 118.9 & 118.1 & 118.5 & 116.6 \\
\hline Wayne & 100.0 & 140,0 & 155.9 & 165.1 & 174.4 & 175.9 & 181.5 \\
\hline Webster & 100.0 & 89.8 & 91.4 & 91.8 & 93.7 & 93.3 & 91.8 \\
\hline Wetzel & 100.0 & 107.6 & 111,6 & 111.1 & 115.0 & 115.8 & 112.1 \\
\hline Firt & 100.0 & 78.8 & 82.3 & 86.9 & 97.5 & 94.7 & 124.4 \\
\hline Wond & 100.0 & 129.8 & 139.0 & 142.0 & 144.8 & 142.5 & 133.1 \\
\hline Wyoming & 100.0 & 109.2 & 109.5 & 114.6 & 119.6 & 117.7 & 114.2 \\
\hline TOTAL & 100.0 & 114.7 & 122.0 & 122.6 & 127.5 & 126.9 & 128.1 \\
\hline
\end{tabular}

Section VII

TRANSPORTATION AND ROADS

W. Vo. Univ.

Agr. Exp. Sta.

Bul. No. 464 


\section{TABLE 3A. TOTAL MILES OF ROADS (ALL TYPES) IN THE COUNTIES OF WEST VIRGINIA}

Data presented in this table were taken from the reports of the Planning Division of the State Road Commission of West Virginia as published in the West Virginia Blue Book. Data for the years 1956-1958 were omitted because of the smallness of the variations.

Section VII

TRANSPORTATION

AND ROADS

W. Yo. Univ.

Agr. Exp. Sta

Bul. No. 464

Page 78

\begin{tabular}{|c|c|c|c|c|c|c|c|}
\hline COUNTY & 1940 & 1950 & 1955 & 1959 & & & \\
\hline Barbour & & 647.20 & 611.34 & 616.33 & & & \\
\hline Berkeley & & 408.41 & 477.27 & 478.10 & & & \\
\hline Boone & & 355.00 & 341.84 & 352.68 & & & \\
\hline Braxton & & 869.59 & 798.38 & 790.39 & & & \\
\hline Brooke & & 167.86 & 169.56 & 169.54 & & & \\
\hline Cabell & & 551.48 & 519.04 & 528.92 & & & \\
\hline Calhouo & & 523.91 & 470.54 & 470.76 & & & \\
\hline Clay & & 481.70 & 451.28 & 452.75 & & & \\
\hline Doddridge & & 524.98 & 515.19 & 514.35 & & & \\
\hline Fayette & & 754.45 & 769.92 & 776.85 & & & \\
\hline Gilmer & & 627.11 & 509.97 & 508,14 & & & \\
\hline Grant & & 378.54 & 338.54 & 338.46 & & & \\
\hline Greeo brier & & 919.65 & 895.26 & 911.38 & & & \\
\hline Hampshire & & 667.60 & 655.82 & 655.96 & & & \\
\hline Hancock & & 188.79 & 188.41 & 186.35 & & & \\
\hline Hardy & & 434.85 & 426.08 & 430.19 & & & \\
\hline Harrisoo & & 793.69 & 795.24 & 785.85 & & & \\
\hline Jacksoo & & 908.02 & 838.17 & 842.28 & & & \\
\hline Jeffersoo & & 317,10 & 317.31 & 316.84 & & & \\
\hline Kanawha & & $1,143.41$ & $1,116.99$ & $1,078.14$ & & & \\
\hline Lewis & & 630.32 & 616.66 & 616.66 & & & \\
\hline Lincolo & & 625.43 & 561.73 & 562.29 & & & \\
\hline Logaa & & 320.93 & 324.68 & 327.24 & & & \\
\hline McDowell & & 504.24 & 507.36 & 510.96 & & & \\
\hline Marion & & 706.35 & 707.20 & 692.28 & & & \\
\hline Marshall & & 542.28 & 553.57 & 551.16 & & & \\
\hline Mason & & 807.48 & 756.79 & 757.98 & & & \\
\hline Mercer & & 758.43 & 763.72 & 764.63 & & & \\
\hline Mineral & & 411.25 & 380,92 & 381.20 & & & \\
\hline Miogo & & 385.97 & 365.64 & 368.39 & & & \\
\hline Moooogalia & & 765,65 & 760.40 & 762.61 & & & \\
\hline Monroe & & 589,17 & 562.33 & 563.27 & & & \\
\hline Morgac & & 351.44 & 344.65 & 345.02 & & & \\
\hline Nicholas & & 654.56 & 624.30 & 633.40 & & & \\
\hline Ohio & & 215.11 & 215.28 & 216.82 & & & \\
\hline Pendletoo & & 542.78 & 494.54 & 494.63 & & & \\
\hline Pleasants & & 254.93 & 253.27 & 246.16 & & & \\
\hline Pocahootas & & 660.42 & 570.91 & 571.76 & & & \\
\hline Prestoo & & $1,208.60$ & $1,212.09$ & $1,213.90$ & & & \\
\hline Putoam & & 643.38 & 591.61 & 592.11 & & & \\
\hline Raleigh & & 741.47 & 740.67 & 744.69 & & & \\
\hline Randolph & & 847.27 & 758.11 & 784.26 & & & \\
\hline Ritchie & & 763.60 & 760.86 & 760.74 & & & \\
\hline Roace & & 923.76 & 811.26 & 811.26 & & & \\
\hline Summers & & 534.83 & 532.53 & 536.14 & & & \\
\hline Taylor & & 373.37 & 376.02 & 377.33 & & & \\
\hline Tucker & & 388.61 & 393.64 & 396.02 & & & \\
\hline Tyler & & 443,85 & 444.94 & 434.68 & & & \\
\hline Upshur & & 708.32 & 691.53 & 691.73 & & & \\
\hline W/ayoe & & 860,20 & 809.74 & 809.76 & & & \\
\hline Webster & & 473.76 & 447.65 & 448.37 & & & \\
\hline Wetzel & & 600,77 & 604.34 & 597.36 & & & \\
\hline Wirt & & 392.65 & 389.77 & 388.73 & & & \\
\hline Wood & & 757.13 & 740.26 & 741.19 & & & \\
\hline Wyoming & & 422.96 & 424.05 & 425.18 & & & \\
\hline TOTAL & & $32,504.61$ & $31,299.13$ & $31,324.17$ & & & \\
\hline
\end{tabular}


Data presented here are taken from the annual reports of the Planning Division of the State Road Commission, as published in the West Virginia Blue Book. "High type" roads are those roads which were constructed to meet the minimum specifications established by the Bureau of Public Roads, United States Department of Commerce.

\begin{tabular}{|c|c|c|c|c|c|c|c|}
\hline COUNTY & 1940 & 1950 & 1955 & 1956 & 1957 & 1958 & 1959 \\
\hline Barbour & & 74.82 & 91.84 & 94.72 & 94.72 & 104.30 & 131.70 \\
\hline Berkeley & & 54.45 & 162.09 & 165.76 & 188.41 & 193.76 & 200.14 \\
\hline Boone & & 39.75 & 83.23 & 99.58 & 117.36 & 117.36 & 136.82 \\
\hline Braxton & & 62.85 & 74.42 & 82.55 & 83.04 & 93.90 & 104.49 \\
\hline Brooke & & 49.05 & 57.02 & 57.03 & 57.03 & 60.83 & 60.83 \\
\hline Cabell & & 120.88 & 143.97 & 144.06 & 145.05 & 152.76 & 153.99 \\
\hline Calhoun & & 27.70 & 34.14 & 50.95 & 56.95 & 65.81 & 65.81 \\
\hline Clay & & 42.14 & 68.95 & 68.95 & 68.95 & 71.52 & 72.12 \\
\hline Doddridge & & 42.33 & 71.15 & 71.18 & 76.43 & 80.73 & 80.75 \\
\hline Fayecte & & 154.00 & 228.37 & 242.03 & 258.10 & 266.54 & 268.31 \\
\hline Gilmer & & 38.34 & 64.95 & 70.93 & 70.93 & 88.97 & 88.97 \\
\hline Grant & & 32.27 & 63.65 & 76.54 & 85.50 & 93.28 & 97.52 \\
\hline Greeobrier & & 100.74 & 200.31 & 209.81 & 224.07 & 261.05 & 265.98 \\
\hline Hampshire & & 62.13 & 102.79 & 104.23 & 104.23 & 126.88 & 133.13 \\
\hline Hancock & & 52.98 & 64.41 & 64.41 & 64.43 & 70.73 & 70.86 \\
\hline Hardy & & 49.47 & 67.10 & 72.46 & 98.50 & 105.04 & 116.37 \\
\hline Harrison & & 214.95 & 233.71 & 230.75 & 233.31 & 237.84 & 238.23 \\
\hline Jackson & & 46.13 & 94.28 & 105.70 & 110.41 & 115.31 & 118.41 \\
\hline Jeffersna & & 52.78 & 91.77 & 95.77 & 106.05 & 114.00 & 114.00 \\
\hline Kanawha & & 235.29 & 275.58 & 279.87 & 293.68 & 298.03 & 301.00 \\
\hline Lewis & & 78.55 & 90.56 & 90.56 & 92.90 & 92.90 & 92.90 \\
\hline Lincoln & & 38.81 & 63.59 & 63.59 & 63.59 & 63.59 & 63.59 \\
\hline Logan & & 84.59 & 111.58 & 112.49 & 124.66 & 127.57 & 146.09 \\
\hline McDowell & & 80.59 & 111.30 & 122.42 & 125.25 & 142.10 & 148.32 \\
\hline Marion & & 181.99 & 182.59 & 179.11 & 183.45 & 189.44 & 190.00 \\
\hline Marshall & & 94.62 & 119.30 & 119.34 & 119.34 & 133.07 & 135.07 \\
\hline Mason & & 83.39 & 90.71 & 90.71 & 115.25 & 115.76 & 124.36 \\
\hline Mercer & & 52.52 & 134.44 & 144.84 & 152.27 & 163.79 & 163.85 \\
\hline Mineral & & 46.60 & 61.99 & 73.01 & 75.26 & 85.49 & 87.75 \\
\hline Mingo & & 29.62 & 67.55 & 68.36 & 79.12 & 87.14 & 110.48 \\
\hline Mooongalia & & 163.84 & 189.40 & 190.98 & 196.82 & 197.72 & 199.41 \\
\hline Monroe & & 21.93 & 68.54 & 83.33 & 91.40 & 96.15 & 109.39 \\
\hline Morgao & & 24.65 & 56.88 & 66.23 & 77.46 & 83.63 & 91.39 \\
\hline Nicholas & & 70,48 & 131.17 & 141.04 & 171.15 & 185.15 & 190.19 \\
\hline Ohio & & 83.96 & 113.17 & 113.81 & 113.76 & 119.54 & 119.73 \\
\hline Peadleton & & 60.35 & 81.97 & 81.97 & 86.12 & 104.76 & 104.76 \\
\hline Pleasaots & & 23.58 & 28.53 & 28.53 & 28.53 & 33.64 & 34.67 \\
\hline Pocahontas & & 89.33 & 147.72 & 147.75 & 157.50 & 167.13 & 198.52 \\
\hline Preston & & 118.31 & 194.86 & 196.85 & 206.38 & 214.81 & 217.57 \\
\hline Putnam & & 62.63 & 86.97 & 92.52 & 92.52 & 97.24 & 98.45 \\
\hline Raleigh & & 105.47 & 142.40 & 143.08 & 143.14 & 150.34 & 185.73 \\
\hline Randolph & & 96.47 & 135.85 & 138.50 & 168.69 & 182.80 & 188.82 \\
\hline Ritchie & & 105,34 & 101.44 & 105.24 & 105.24 & $120.4 \mathrm{I}$ & 120.41 \\
\hline Roane & & 76.07 & 83.29 & 88.02 & 88,65 & 91.77 & 91.79 \\
\hline Summers & & 52.72 & 123.88 & 128.02 & 130.80 & 139.60 & 145.27 \\
\hline Taylor & & 59.77 & 69.79 & 73.23 & 81.83 & 92.77 & 101.00 \\
\hline Tucker & & 46.78 & 77.98 & 77.98 & 82.84 & 90.95 & 95.86 \\
\hline Tyler & & 41.35 & 66.40 & 66.40 & 66.40 & 81.07 & 81.15 \\
\hline Upshur & & 50.50 & 78.17 & 78.17 & 78.17 & 88,54 & 88.51 \\
\hline Wayoe & & 46.68 & 96.03 & 103.58 & 113.18 & 123.51 & 138.27 \\
\hline Webster & & 38.41 & 71.42 & 83.06 & 85.59 & 92.21 & 102.25 \\
\hline Wetzel & & 122,61 & 152.27 & 154.02 & 154.02 & 163.02 & 163.40 \\
\hline Wirt & & 29.44 & 37.42 & 37.42 & 37.42 & 45.31 & 53.41 \\
\hline Wood & & 11164 & 121.29 & 136,00 & 15099 & 157,36 & 152.34 \\
\hline Wyoming & & 28.15 & 63.85 & 64.67 & 77.80 & 95.09 & 95.92 \\
\hline TOTAL & & $4,054.79$ & $5,828,03$ & $6,072,11$ & 6.454 .64 & $6,934,01$ & $7,255.05$ \\
\hline
\end{tabular}

Section VII

TRANSPORTATION AND RDADS

W. Va. Unir.

Agr. Exp. Sta.

Bul. No. 464

Page 79 
TABLE 3C. THE PERCENTAGES OF TOTAL MILEAGE IN ROADS CLASSIFIED AS "HIGH TYPE" ROADS FOR THE COUNTIES OF WEST VIRGINIA

The information presented in this table was secured by dividing the data presented in Table $3 \mathrm{~A}$, of this section by the data presented in Table 3B of this section and multiplying the results by 100 .

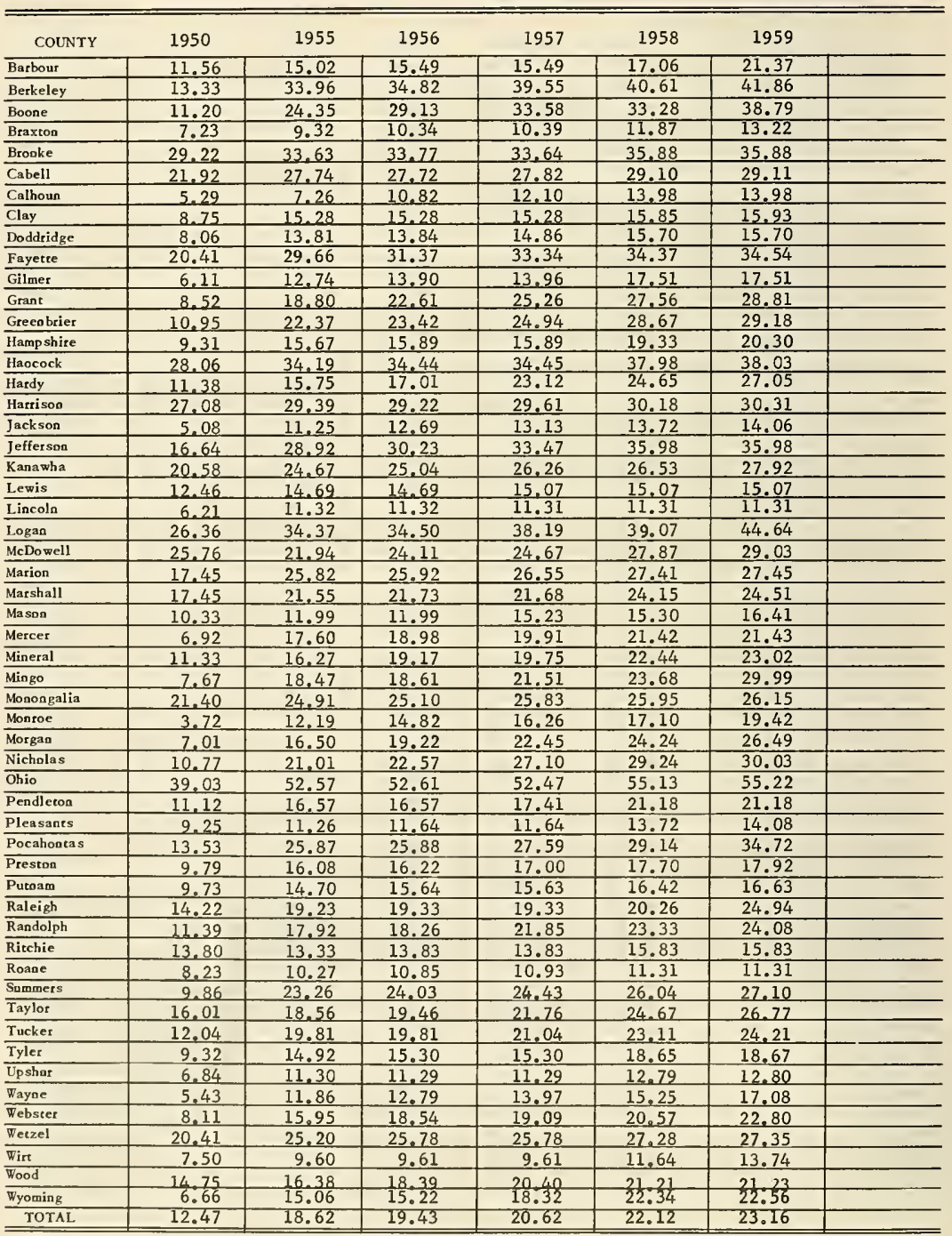

W. Yo. Unir.

Agr. Exp. Sto.

Bul. No. 464

Page 80
ANSPORTATION AND ROADS

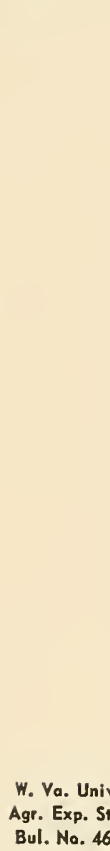


TABLE 3D. INDEX OF THE NUMBER OF MILES OF "HIGH TYPE" ROADS IN THE COUNTIES OF WEST VIRGINIA, $1950=100$

The information presented here is based upon the data presented in the preceding table, Table 3B, Section VII.

\begin{tabular}{|c|c|c|c|c|c|c|c|}
\hline COUNTY & 1940 & 1950 & 1955 & 1956 & 1957 & 1958 & 1959 \\
\hline Barbour & & 100.0 & 122.7 & 126.6 & 126.6 & 139.4 & 176.0 \\
\hline Berkeley & & 100.0 & 297.7 & 304.4 & 346.0 & 355.8 & 367.6 \\
\hline Boone & & 100.0 & 209.4 & 250.5 & 295.2 & 295.2 & 344.2 \\
\hline Braxron & & 100.0 & 118.4 & 131.3 & 132.1 & 149.4 & 166.3 \\
\hline Brooke & & 100.0 & 116.2 & 116.3 & 116.3 & 124.0 & 124.0 \\
\hline CaheIl & & 100.0 & 119.1 & 119.2 & 120.0 & 126.4 & 127.4 \\
\hline Calhoun & & 100.0 & 123.2 & 183.9 & 205.6 & 237.6 & 237.6 \\
\hline Clay & & 100.0 & 163.6 & 163.6 & 163.6 & 169.7 & 171.1 \\
\hline Doddridge & & 100.0 & 168.1 & 168.2 & 180.6 & 190.7 & 190.8 \\
\hline Fayerte & & 100.0 & 148.3 & 157.2 & 167.6 & 173.1 & 174.2 \\
\hline Gilmer & & 100.0 & 169.4 & 185.0 & 185.0 & 232.1 & 232.1 \\
\hline Grant & & 100.0 & 197.2 & 237.2 & 265.0 & 289.1 & 302.2 \\
\hline Greenbrier & & 100.0 & 198.8 & 208.3 & 222.4 & 259.1 & 264.0 \\
\hline Hampshire & & 100.0 & 165.4 & 167.8 & 167.8 & 204.2 & 214.3 \\
\hline Hancnck & & 100.0 & 121.6 & 121.6 & 121.6 & 133.5 & 133.7 \\
\hline Hardy & & 100.0 & 135.6 & 146.5 & 199.1 & 212.3 & 235.2 \\
\hline Harrison & & 100.0 & 108.7 & 107.3 & 108.5 & 110.6 & 110.8 \\
\hline Jackson & & 100.0 & 204.4 & 229.1 & 239.3 & 250.0 & 256.7 \\
\hline Jeffersoo & & 100.0 & 173.9 & 181.5 & 200.9 & 216.0 & 216.0 \\
\hline Kanawha & & 100.0 & 117.1 & 118.9 & 124.8 & 216.7 & 127,9 \\
\hline Lewis & & 100.0 & 115.3 & 115.3 & 118.3 & 118.3 & 118.3 \\
\hline Lincnlo & & 100.0 & 163.8 & 163.8 & 163.8 & 163.8 & 163.8 \\
\hline Lngan & & 100.0 & 131.9 & 133.0 & 146.4 & 150.8 & 172.7 \\
\hline McDoweIl & & 100.0 & 138.1 & 151.9 & 155.4 & 176.3 & 184.0 \\
\hline Marinn & & 100.0 & 100.3 & 98,4 & 100,8 & 104.1 & 104.4 \\
\hline Marshall & & 100.0 & 126.1 & 126.1 & 126,1 & 140.6 & 142.7 \\
\hline Mason & & 100.0 & 108.8 & 108.8 & 138.2 & 138.8 & 149.1 \\
\hline Mercer & & 100.0 & 256.0 & 275.8 & 290.0 & 311.9 & 312.0 \\
\hline Mineral & & 100.0 & 133.0 & 156.7 & 161.5 & 183.5 & 188.3 \\
\hline Mingo & & 100.0 & 228.1 & 230.8 & 267.1 & 294.2 & 373.0 \\
\hline Moooogalia & & 100.0 & 115.6 & 116.6 & 120.1 & 120.7 & 121.7 \\
\hline Mnnrde & & 100.0 & 312.5 & 380.0 & 416.8 & 438.4 & 498.8 \\
\hline Morgan & & 100.0 & 230.8 & 268.7 & 314.2 & 339.3 & 370.8 \\
\hline Nicholas & & 100.0 & 186.1 & 200.1 & 242.8 & 262.7 & 269.8 \\
\hline Ohio & & 100.0 & 134.8 & 135.6 & 135.5 & 142.4 & 142.6 \\
\hline Pendleton & & 100.0 & 135.8 & 135.8 & 142.7 & 173.6 & 173.6 \\
\hline Pleasants & & 100.0 & 121.0 & 121.0 & 121.0 & 142.7 & 147.0 \\
\hline Pocahontas & & 100.0 & 165.4 & 165.4 & 176.3 & 187.1 & 222.2 \\
\hline Prestnn & & 100.0 & 164.7 & 166.4 & 174.4 & 181.6 & 183.9 \\
\hline Putnam & & 100.0 & 138.9 & 147.7 & 147.7 & 155.3 & 157.2 \\
\hline Raleigh & & 100.0 & 135.0 & 135.7 & 135.7 & 142.5 & 176.1 \\
\hline Randolpb & & 100.0 & 140.8 & 143.6 & 174.9 & 189.5 & 195.7 \\
\hline Ritchie & & 100.0 & 96.3 & 99.9 & 99.9 & 114.3 & 114.3 \\
\hline Roaoe & & 100.0 & 109.5 & 115.7 & 116.5 & 120.6 & 120.7 \\
\hline Summers & & 100.0 & 235.0 & 242.8 & 248.1 & 264.8 & 275.5 \\
\hline Taylor & & 100.0 & 116.8 & 122.5 & 136.9 & 155.2 & 169.0 \\
\hline Tucker & & 100.0 & 166.7 & 166.7 & 177.1 & 194.4 & 204.9 \\
\hline Tyler & & 100.0 & 160.6 & 160.6 & 160.6 & 196.1 & 196.3 \\
\hline Upshus & & 100.0 & 154.8 & 154.8 & 154.8 & 175.3 & 175.3 \\
\hline Wayne & & 100.0 & 205.7 & 221.9 & 242.5 & 264.6 & 296.2 \\
\hline Wehster & & 100.0 & 185,9 & 216.2 & 222.8 & 240.1 & 266.2 \\
\hline Wetzel & & 100.0 & 124.2 & 125.6 & 125.6 & 133.0 & 133.3 \\
\hline Wirt & & 100.0 & 127.1 & 127.1 & 127.1 & 153.9 & 181.4 \\
\hline Wood & & 100.0 & 108.6 & 121.8 & 135.2 & 141.0 & 140.9 \\
\hline Wypming & & 100.0 & 226.8 & 229.7 & 276.4 & 337.8 & 340.7 \\
\hline TOTAL & & 100.0 & 143.7 & 149.7 & 159.2 & 171.0 & 178.9 \\
\hline
\end{tabular}

Section VII

TRANSPORTATION AND ROADS

W. Va. Univ.

Agr. Exp. Sta.

Bul. Na. 464

Page 81 


\section{TABLE 4A. THE NUMBER OF PERSONS PER MILE OF "HIGH TYPE" ROADS FOR THE COUNTIES OF WEST VIRGINIA}

The data presented in this table are the results of dividing the information in Table 3B, Section VII, Transportation and Roads, into the estimates of population for counties of West Virginia, as presented in Table 2A, Section I, Population and Vital Statistics.

Section VII

TRANSPORTATION AND ROADS

W. Va. Univ,

Agr, Exp. Sto. Bul. No. 464

Page 82

\begin{tabular}{|c|c|c|c|c|c|c|c|}
\hline COUNTY & 1950 & 1955 & 1956 & 1957 & 1958 & & \\
\hline Barbour & 264 & 200 & 183 & 184 & 162 & & \\
\hline Berkeley & 558 & 198 & 194 & 173 & 171 & & \\
\hline Boone & 835 & 426 & 347 & 292 & 179 & & \\
\hline Beaxton & 288 & 235 & 202 & 203 & 174 & & \\
\hline Brnoke & 549 & 502 & 514 & 516 & 462 & & \\
\hline Cabell & 894 & 764 & 758 & 750 & 710 & & \\
\hline Calhoun & 370 & 285 & 185 & 167 & 146 & & \\
\hline Clay & 355 & 223 & 219 & 213 & 207 & & \\
\hline Doddridge & 213 & 113 & 105 & 95 & 87 & & \\
\hline Fayette & 535 & 334 & 307 & 284 & 273 & & \\
\hline Gilmer & 254 & 137 & 119 & 116 & 92 & & \\
\hline Grant & 271 & 134 & 109 & 98 & 90 & & \\
\hline Greenbrier & 390 & 192 & 183 & 171 & 144 & & \\
\hline Hampshire & 202 & 123 & 119 & 123 & 103 & & \\
\hline Hancock & 649 & 584 & 588 & 599 & 569 & & \\
\hline Hardy & 203 & 145 & 130 & 96 & 90 & & \\
\hline Harrison & 397 & 354 & 348 & 345 & 337 & & \\
\hline Jackson & 332 & 163 & 149 & 154 & 165 & & \\
\hline Jefferson & 326 & 188 & 171 & 157 & 152 & & \\
\hline Kanawha & 1,018 & 904 & 885 & 853 & 847 & & \\
\hline Lewis & 268 & 227 & 218 & 215 & 213 & & \\
\hline Lincnla & 579 & 375 & 354 & 367 & 376 & & \\
\hline Logan & 915 & 631 & 644 & 592 & 578 & & \\
\hline McDowell & 1,227 & 823 & 716 & 696 & 597 & & \\
\hline Marion & 393 & 362 & 358 & 351 & 338 & & \\
\hline Marshali & 390 & 303 & 305 & 303 & 283 & & \\
\hline Masan & 282 & 267 & 270 & 206 & 210 & & \\
\hline $\begin{array}{l}\text { Mercer } \\
\end{array}$ & 1,428 & 545 & 493 & 481 & 442 & & \\
\hline Mineral & 479 & 351 & 284 & 283 & 247 & & \\
\hline Mingo & 1,601 & 724 & 751 & 621 & 555 & & \\
\hline Monongalia & 371 & 305 & 293 & 286 & 279 & & \\
\hline Monroe & 598 & 199 & 157 & 139 & 133 & & \\
\hline Morgan & 336 & 145 & 123 & 107 & 98 & & \\
\hline Nicholas & 393 & 215 & 197 & 166 & 152 & & \\
\hline Ohis & 854 & 607 & 607 & 613 & 580 & & \\
\hline Pendleton & 154 & 111 & 110 & 104 & 85 & & \\
\hline Pleasants & 270 & 245 & 250 & 251 & 225 & & \\
\hline Pocahootas & 140 & 79 & 79 & 72 & 68 & & \\
\hline Preston & 265 & 157 & 147 & 138 & 131 & & \\
\hline Putnam & 336 & 282 & 261 & 264 & 258 & & \\
\hline Raleigh & 913 & 645 & 615 & 619 & 593 & & \\
\hline Randolph & 317 & 212 & 206 & 166 & 152 & & \\
\hline Ritchic & 119 & 112 & 101 & 102 & 90 & & \\
\hline Roane & 242 & 217 & 199 & 193 & 182 & & \\
\hline Summers & 364 & 140 & 131 & 127 & 121 & & \\
\hline Taylor & 308 & 246 & 230 & 201 & 175 & & \\
\hline Tucker & 227 & 113 & 106 & 99 & 88 & & \\
\hline Tyler & 255 & 153 & 154 & 151 & 126 & & \\
\hline Upshur & 381 & 239 & 237 & 227 & 202 & & \\
\hline Wayne & 829 & 421 & 390 & 355 & 330 & & \\
\hline Webster & 466 & 239 & 203 & 198 & 180 & & \\
\hline Wetzel & 164 & 127 & 124 & 123 & 121 & & \\
\hline Wirt & 174 & 135 & 128 & 132 & 106 & & \\
\hline Wood & 596 & 571 & 523 & 486 & 481 & & \\
\hline Wyoming & 1,334 & 646 & 642 & 538 & 439 & & \\
\hline TOTAL & 495 & 340 & 322 & 304 & 283 & & \\
\hline
\end{tabular}


The inIormation presented in this table is based upon the data presented in the preceding table, Table 4A, Section VIl.

\begin{tabular}{|c|c|c|c|c|c|c|c|}
\hline COUNTY & 1950 & 1955 & 1956 & 1957 & 1958 & & \\
\hline Batbour & 100.0 & 75.8 & 69.3 & 69.7 & 61.4 & & \\
\hline Berkeley & 100.0 & 35.5 & 34.8 & 31.0 & 30.6 & & \\
\hline Boone & 100.0 & 51.0 & 41.6 & 35.0 & 21.4 & & \\
\hline Beaxton & 100.0 & 81.6 & 70.1 & 70.5 & 60.4 & & \\
\hline Brooke & 100.0 & 91.4 & 93.6 & 94.0 & 84.2 & & \\
\hline Cabell & 100.0 & 85.5 & 84.8 & 83.9 & 79.4 & & \\
\hline Calhoun & 100.0 & 77.0 & 50,0 & 45.1 & 39.5 & & \\
\hline Clay & 100.0 & 62.8 & 61.7 & 60.0 & 58.3 & & \\
\hline Doddridge & 100.0 & 53.1 & 49.3 & 44.6 & 40.8 & & \\
\hline Fayette & 100.0 & 62.4 & 57.4 & 53,1 & 51.0 & & \\
\hline Gilmer & 100.0 & 53.9 & 46.8 & 45.7 & 36.2 & & \\
\hline Granr & 100.0 & 49.4 & 40.2 & 36.2 & 33.2 & & \\
\hline Greenbrier & 100.0 & 49.2 & 46.9 & 43.8 & 36.9 & & \\
\hline Hampshire & 100.0 & 60.9 & 58.9 & 60.9 & 51.0 & & \\
\hline Hancock & 100.0 & 90.0 & 90,6 & 92.3 & 87.7 & & \\
\hline Hardy & 100,0 & 71.4 & 64.0 & 47.3 & 44.3 & & \\
\hline Harrison & 100.0 & 89.2 & 87.7 & 86.9 & 84.9 & & \\
\hline Jackson & 100.0 & 49.1 & 44.9 & 46.4 & 49.7 & & \\
\hline Jefferson & 100.0 & 57.7 & 52.5 & 48.2 & 46.6 & & \\
\hline Kanawha & 100.0 & 88.8 & 86.9 & 83.8 & 83.2 & & \\
\hline Lewis & 100.0 & 84.7 & 81.3 & 80.2 & 79.5 & & \\
\hline Lincoln & 100.0 & 64.8 & 61,1 & 63.4 & 64.9 & & \\
\hline Logaa & 100,0 & 69.0 & 70.4 & 64.7 & 63.2 & & \\
\hline McDowell & 100.0 & 67.1 & 58.4 & 56.7 & 48.7 & & \\
\hline Marion & 100.0 & 92.1 & 91.1 & 89.3 & 86.0 & & \\
\hline Marshall & 100.0 & 77.7 & 78.2 & 77.7 & 72.6 & & \\
\hline Mason & 100.0 & 94.7 & 95.7 & 73.0 & 74.5 & & \\
\hline Mercer & 100.0 & 38.2 & 34.5 & 33.7 & 31.0 & & \\
\hline Mineral & 100.0 & 73.3 & 59.3 & 59.1 & 51.6 & & \\
\hline Mingo & 100.0 & 45.2 & 46.9 & 38.8 & 34.7 & & \\
\hline Monongalia & 100.0 & 82.2 & 79.0 & 77.1 & 75.2 & & \\
\hline Moaroe & 100.0 & 33.3 & 26.3 & 23.2 & 22.2 & & \\
\hline Motgan & 100.0 & 43.2 & 36.6 & 31.8 & 29.2 & & \\
\hline Nicholas & 100.0 & 54.7 & 50,1 & 42.2 & 38.7 & & \\
\hline Ohio & 100.0 & 71.1 & 71.1 & 71.8 & 67.9 & & \\
\hline Pendletoa & 100.0 & 72.1 & 71.4 & 67.5 & 55.2 & & \\
\hline Pleasants & 100.0 & 90.7 & 92.6 & 93.0 & 83.3 & & \\
\hline Pocahoatas & 100.0 & 56.4 & 56.4 & 51.4 & 48.6 & & \\
\hline Presfoo & 100.0 & 59.2 & 55.5 & 52.1 & 49.4 & & \\
\hline Puteam & 100.0 & 83.9 & 77.7 & 78.6 & 76.8 & & \\
\hline Raleigh & 100.0 & 70.6 & 67.4 & 67.8 & 65.0 & & \\
\hline Randolph & 100.0 & 66,9 & 65.0 & 52.4 & 47.9 & & \\
\hline Ritchie & 100.0 & 94.1 & 84.9 & 85.7 & 75.6 & & \\
\hline Roane & 100.0 & 89.7 & 82.2 & 79.8 & 75.2 & & \\
\hline Summers & 100.0 & 38.5 & 36.0 & 34.9 & 33.2 & & \\
\hline Taylor & 100.0 & 79.9 & 74.7 & 65.3 & 56.8 & & \\
\hline Tucker & 100.0 & 49.8 & 46.7 & 43.6 & 38.8 & & \\
\hline Tyler & 100.0 & 60.0 & 60.4 & 59.2 & 49.4 & & \\
\hline Upshur & 100.0 & 62.7 & 62.2 & 59.6 & 53.0 & & \\
\hline Wayoe & 100.0 & 50,8 & 47.0 & 42.8 & 39.8 & & \\
\hline Webster & 100,0 & 51.3 & 43.6 & 42.5 & 38.6 & & \\
\hline Wetzel & 100.0 & 77.4 & 75.6 & 75.0 & 73.8 & & \\
\hline Wirt & 100.0 & 77.6 & 73.6 & 75.9 & 60.9 & & \\
\hline Wood & 100.0 & 95.8 & 87.8 & 81.5 & 80.7 & & \\
\hline Wyoming & 100.0 & 48.4 & 48.1 & 40.3 & 32.9 & & \\
\hline TOTAL & 100.0 & 68.7 & 65.0 & 61.4 & 57.2 & & \\
\hline
\end{tabular}

Section VII

TRANSPORTATION AND ROADS

w. Vo. Univ. Agr. Exp. Sta. Bul. No. 464

Page 83 
TABLE 5A. THE NUMBER OF MILES OF "HIGH TYPE" ROADS PER 100 SQUARE MILES OF AREA FOR THE COUNTIES OF WEST VIRGINIA

The information presented here was computed by dividing the data presented in Table $2 \mathrm{~A}$, Section VII, by the areas of the counties and multiplying the quotient by 100 .

Section VII

TRANSPORTATION AND ROADS

w. Va. Unir. Agr. Exp. Sto. Bul. No. 464

Page 84




TABLE 5B. INDEX OF THE NUMBER OF MILES OF "HIGH TYPE" ROAD PER 100 SQUARE MILES OF AREA FOR THE COUNTIES

OF WEST VIRGINIA, $1950=100$

The data presented here is based on information in the preceding table, Table 5A, Section VII.

\begin{tabular}{|c|c|c|c|c|c|c|c|}
\hline COUNTY & 1950 & 1955 & 1956 & 1957 & 1958 & 1959 & \\
\hline Barbour & 100.0 & 122.6 & 126.3 & 126.3 & 139.2 & 175.6 & \\
\hline Berkeley & 100.0 & 297.0 & 303.6 & 345.2 & 354.8 & 366.7 & \\
\hline Boone & 100.0 & 210.3 & 252.6 & 297.4 & 297.4 & 346.2 & \\
\hline Braxton & 100.0 & 118.2 & 131.4 & 132.2 & 149.6 & 166.1 & \\
\hline Brooke & 100.0 & 116.2 & 116.4 & 116.4 & 124.2 & 124.2 & \\
\hline Cabell & 100.0 & 118.9 & 119.1 & 119.9 & 126.2 & 127.4 & \\
\hline Calhoun & 100.0 & 123.2 & 183.8 & 205.0 & 237.4 & 237.4 & \\
\hline Clay & 100.0 & 163.1 & 163.1 & 163.1 & 168.9 & 170.5 & \\
\hline Doddridge & 100.0 & 167.4 & 167.4 & 180.3 & 190.2 & 190.2 & \\
\hline Fayette & 100.0 & 148.5 & 157.2 & 167.5 & 173.2 & 174.5 & \\
\hline Gilmer & 100.0 & 169.6 & 184.8 & 184.8 & 232.1 & 232.1 & \\
\hline Grant & 100.0 & 195.6 & 235.3 & 263.2 & 286.8 & 300.0 & \\
\hline Greenbrier & 100.0 & 200.0 & 209.2 & 223.5 & 260.2 & 265.3 & \\
\hline Hampshire & 100,0 & 166,7 & 168.7 & 168.7 & 206.2 & 216.7 & \\
\hline Hancnck & 100,0 & 121.6 & 121,6 & 121.7 & 133.6 & 133.8 & \\
\hline Hardy & 100.0 & 136.0 & 146.5 & 198.8 & 212.8 & 234.9 & \\
\hline Harrison & 100.0 & 108,8 & 107,4 & 108,6 & 110.7 & 110.9 & \\
\hline Jacksoo & 100,0 & 204.1 & 228,6 & 238.8 & 249.0 & 255.1 & \\
\hline Jefferson & 100.0 & 174.2 & 181.9 & 201,2 & 216,5 & 216.5 & \\
\hline Kanawha & 100,0 & 117.1 & 118,6 & 124.8 & 126.4 & 127.9 & \\
\hline Lewis & 100.0 & 114.9 & 114.9 & 117.9 & 117.9 & 117.9 & \\
\hline Lincolo & 100.0 & 164.0 & 164.0 & 164.0 & 164.0 & 164.0 & \\
\hline Logan & 100.0 & 131.7 & 132.8 & 146.8 & 150.1 & 172.0 & \\
\hline McDowell & 100.0 & 138.0 & 151.3 & 155.3 & 176.0 & 183.0 & \\
\hline Marion & 100.0 & 100.3 & 98,4 & 100,9 & 104.1 & 104.5 & \\
\hline Marshall & 100,0 & 126.0 & 126.3 & 126.3 & 140.7 & 142.7 & \\
\hline Mason & 100.0 & 108.6 & 108.6 & 138.5 & 139.0 & 149.2 & \\
\hline Mercer & 100.0 & 255.6 & 275.8 & 289.5 & 311.3 & 312.1 & \\
\hline Mineral & 100.0 & 133.3 & 156.7 & 161.7 & 183.7 & 188.7 & \\
\hline Mingo & 100.0 & 228.6 & 230.0 & 267.1 & 294.3 & 372.9 & \\
\hline Monongalia & 100.0 & 115.8 & 116.7 & 120.3 & 120.7 & 121.8 & \\
\hline Mnnine & 100.0 & 315.2 & 382.6 & 419.6 & 441.3 & 502.2 & \\
\hline Morgan & 100.0 & 229.9 & 267.3 & 313.1 & 338.3 & 369.2 & \\
\hline Nicholas & 100,0 & 186.9 & 200.9 & 243.9 & 263.6 & 271.0 & \\
\hline Ohio & 100.0 & 134.8 & 135.6 & 135.6 & 142.5 & 142.6 & \\
\hline Pendleton & 100.0 & 135.6 & 135.6 & 142.5 & 172.4 & 172.4 & \\
\hline Pleasants & 100.0 & 121.1 & 121.1 & 121.1 & 142.9 & 146.9 & \\
\hline Pocahontas & 100.0 & 165.3 & 165.3 & 175.8 & 186.3 & 222.1 & \\
\hline Preston & 100.0 & 164.6 & 166.3 & 174.6 & 181.2 & 184.0 & \\
\hline Putcam & 100.0 & 138.5 & 147.5 & 147.5 & 154.7 & 157.0 & \\
\hline Raleigh & 100.0 & 134.7 & 135.3 & 135.3 & 142.2 & 175.7 & \\
\hline Randolph & 100.0 & 141.3 & 143.5 & 175.2 & 190.2 & 195.7 & \\
\hline Ritchie & 100.0 & 96.5 & 100.0 & 100.0 & 114.3 & 114.3 & \\
\hline Roace & 100.0 & 109.6 & 116.0 & 116.7 & 121.2 & 121.2 & \\
\hline Summers & 100.0 & 235.7 & 243.4 & 249.0 & 265.7 & 276.2 & \\
\hline Taylor & 100.0 & 116.9 & 122.6 & 137.1 & 155.5 & 169.1 & \\
\hline Tucker & 100.0 & 166.7 & 166.7 & 176.6 & 194.6 & 204.5 & \\
\hline Tyler & 100.0 & 160.4 & 160.4 & 160.4 & 196.2 & 196.2 & \\
\hline Upshar & 100.0 & 154.9 & 154.9 & 154.9 & 176.1 & 176.1 & \\
\hline Wayne & 100.0 & 205.6 & 222.2 & 243.3 & 264.4 & 296.7 & \\
\hline Webster & 100,0 & 182.9 & 212.9 & 218.6 & 235.7 & 261.4 & \\
\hline Wetzel & 100.0 & 124.1 & 125.6 & 125.6 & 132.9 & 133.2 & \\
\hline Wirt & 100.0 & 127.0 & 127.0 & 127.0 & 153.2 & 181.0 & \\
\hline Wond & 100,0 & 108.8 & 122.0 & 135.6 & 241.0 & 141.0 & \\
\hline Wyoming & 100.0 & 229.0 & 230.9 & 278.2 & 340.0 & 343.6 & \\
\hline TOTAL & 100.0 & 143.7 & 149.8 & 159.2 & 171.0 & 178.9 & \\
\hline
\end{tabular}

Section VII

TRANSPORTATION

AND ROADS

W. Va. Univ.

Agr. Exp. Sta.

Bul. Na. 464

Page 85 



\section{Section VIII \\ ECONOMIC ACTIVITIES}

Table

IA Personal Income (in Thousands of Dollars) for the Counties of West Virginia .....

IB Persoaal Incomes (in Thousands of Dollars, Adjusted by the Wholesale Commodity Index) for the Counties of West Virginia . . 89

IC Index of Adjusted Personal Income for the Counties of West Virginia, $1950=100 \ldots$.

1D The Personal Income of Each of the Counties of West Virginia, Represented as a Percentage (in Thousandths of 1 Per Cent) of the National Income $\ldots .$.

2A Retail Sales (in Thousands of Dollars) for the Counties of West Virginia ....

2B Retail Sales (in Thousands of Dollars, Adjusted by the Wholesale Commodity Index) for the Counties of West Virginia ....

2C Index to Adjusted Retail Sales for the Counties of West Virginia, $1950=100 \quad \ldots$.

3A Average Number of Employees in the Mining Industry of the Counties of West Virginia ....

3B Index of the Average Number of Employees in the Mining Industry for the Counties of West Virginia, $1950=100 \ldots \ldots$ 
TABLE IA. PERSONAL INCOME (IN THOUSANDS OF DOLLARS) FOR THE COUNTIES OF WEST VIRGINIA

The data presented in this table is from data published by the West Virginia Chamber of Commerce in Personal Income and Retail Sales in West Virginia by Counties for 1958 and other years.

As indicated in these publication, "personal income" is a measure of receipts of individuals derived in the main from these sources: (a) wages and salaries; (b) other labor income such as employer contributions to private pensions, health, welfare, and injury funds; (c) proprietor's income which includes net business earnings of farmers, unincorporated enterprizes, cooperatives, etc.; (d) property income, consisting of rents, royalities, dividends, interest, etc., and (e) transfer payments such as pensions, relief, employment, and old-age benefits, also miscellaneous income such as contributions, cash prizes, consumer bad debts, etc.
Section V III

ECONOMIC

ACTIVITIES

W. Ya. Univ.

Agr. Exp. Sta.

Bul. No. 464

Page 88

\begin{tabular}{|c|c|c|c|c|c|c|c|}
\hline COUNTY & 1940 & 1950 & 1955 & 1957 & 1958 & 1959 & 1960 \\
\hline Barbour & 6,020 & 18,980 & 20,947 & 23,801 & 23,479 & 24,073 & 24,774 \\
\hline Berkeley & 13,142 & 41,050 & 49,651 & 54,711 & 57.062 & 61.553 & 63,661 \\
\hline Boone & 9,420 & 31,339 & 35,687 & 43,274 & 39.230 & 39.004 & 39,827 \\
\hline Braxton & 4,605 & 14,566 & 17,843 & 21,637 & 21,993 & 21,330 & 19,757 \\
\hline Bronke & 12,920 & 34,429 & 41,893 & 45,438 & 44,580 & 44,793 & 46,726 \\
\hline Cabell & 43,700 & 140,807 & 165,762 & 199,060 & 194,369 & 204,160 & 209,799 \\
\hline Calhouo & 2,725 & 6,621 & 7,241 & 8,964 & 8,916 & 9,142 & 9,408 \\
\hline Clay & 4,075 & 12,359 & 14,223 & 15,455 & 14,563 & 14,017 & 13,798 \\
\hline Doddridge & 2,741 & 7,725 & 7,499 & 8,346 & 8,916 & 8,837 & 9,722 \\
\hline Fayette & 35,026 & 92,694 & 96,458 & 105,094 & 98,076 & 99,948 & 102,234 \\
\hline Gilmer & 2,720 & 7,725 & 8,017 & 9,273 & 9,510 & 10,361 & 10,976 \\
\hline Grant & 2,520 & 10,814 & 12,930 & 15,455 & 15,454 & 16,150 & 15,994 \\
\hline Green brier & 12,270 & 37,740 & 43,186 & 51,620 & 49,930 & 50,583 & 51,430 \\
\hline Hampshire & 3,611 & 12,580 & 14,999 & 16,691 & 16,049 & 17,369 & 17,875 \\
\hline Hancock & 27,960 & 51,865 & 64,908 & 77,584 & 76,083 & 88,064 & 91,258 \\
\hline Hardy & 3,190 & 13,463 & 14,999 & 17,001 & 16,346 & 17,369 & 17,875 \\
\hline Harrison & 33,200 & 110,350 & 124,128 & 148,369 & 144,142 & 144,437 & 147,706 \\
\hline Jackson & 4,092 & 15,008 & 19,912 & 55,638 & 35,664 & 42,051 & 43,904 \\
\hline Jeffersnn & 5,580 & 18,318 & 23,791 & 25,655 & 26,451 & 31,995 & 34,810 \\
\hline Kanawha & 97,310 & 299,486 & 375,746 & 450,355 & 443,126 & 468,350 & 480,141 \\
\hline Lewis & 6,442 & 18,318 & 20,429 & 21,637 & 22,290 & 23,158 & 23,520 \\
\hline Lincoln & 4,290 & 13,904 & 18,102 & 21,637 & 20,507 & 20,416 & 21,325 \\
\hline Logan & 28,895 & 88,501 & 98,527 & 124,567 & 109,964 & 106,042 & 106,938 \\
\hline McDowell & 49,580 & 105,053 & 103,957 & 113,749 & 101,048 & 95,377 & 92,512 \\
\hline Marion & 30,285 & 85,411 & 95,682 & 115,294 & 116,205 & 116,097 & 120,422 \\
\hline Marshall & 16,072 & 48,995 & 64,650 & 73,875 & 77,272 & 76,180 & 79,341 \\
\hline Mason & 5,600 & 27,146 & 36,204 & 41,419 & 42,202 & 43,270 & 46,413 \\
\hline Mercer & 28,870 & 81,218 & 93,872 & 111,276 & 106,398 & 101,776 & 103,174 \\
\hline Mineral & 6,600 & 15,670 & 18,878 & 23,183 & 24,668 & 31,415 & 33,892 \\
\hline Mingn & 13,460 & 47,451 & 56,116 & 56,256 & 50,524 & 48,146 & 47,354 \\
\hline Mnnongal ia & 23,100 & 69,300 & 82,752 & 96,748 & 92,132 & 94,463 & 95,021 \\
\hline Monise & 3,272 & 12,139 & 13,189 & 15,455 & 16,346 & 15,236 & 15,680 \\
\hline Morgan & 3,283 & 9,490 & 11,896 & 13,600 & 13,374 & 14,321 & 14,112 \\
\hline Nicholas & 5,941 & 26,043 & 31,549 & 38,019 & 33,881 & 34,434 & 36,064 \\
\hline Ohio & 41,820 & 109,688 & 131,886 & 156,096 & 150,978 & 156,321 & 166,835 \\
\hline Pendleton & 2,635 & 7,062 & 9,310 & 10,819 & 10,996 & 12,798 & 12,544 \\
\hline Pleasaots & 2,372 & 6,180 & 8,275 & 10,509 & 10,699 & 10,665 & 10,976 \\
\hline Pocahontas & 4,562 & 11,256 & 12,930 & 15,764 & 14,266 & 15,540 & 15,679 \\
\hline Preston & 8,212 & 29,574 & 27,670 & 34,001 & 31,503 & 31,995 & 32,923 \\
\hline Putnam & 6.218 & 17,435 & 24,567 & 33,074 & 31,800 & 37,481 & 35,437 \\
\hline Raleigh & 40,082 & 97,329 & 103,440 & 135,077 & 125,418 & 118,840 & 122,304 \\
\hline Randolph & 9.181 & 25,381 & 28.704 & 34,001 & 34,178 & 35,652 & 37,632 \\
\hline Ritchie & 3,960 & 10,594 & 12,413 & 14,219 & 13,968 & 14,017 & 15,053 \\
\hline Roane & 4,925 & 13,904 & 17,068 & 20,401 & 20,804 & 21,330 & 22,893 \\
\hline Summers & 6,280 & 17,435 & 18,619 & 21,328 & 20,210 & 21,026 & 21,325 \\
\hline Taylor & 6,522 & 15,890 & 18,102 & 21,328 & 19,615 & 19,502 & 19,130 \\
\hline Tucker & 3,890 & 9,049 & 9,310 & 10,509 & 10,402 & 10,665 & 11,290 \\
\hline Tyler & 3,391 & 8,166 & 9,827 & 11,128 & 12,185 & 11,580 & 12,545 \\
\hline Upshur & 4,282 & 16,111 & 18,102 & 21,637 & 20,507 & 20,721 & 21,952 \\
\hline Fayne & 7,220 & 26,043 & 34,394 & 39,565 & 38,339 & 40,222 & 44,218 \\
\hline Webstet & 5,135 & 17,215 & 16,292 & 18,855 & 17,535 & 17,369 & 17,562 \\
\hline Wetzel & 6,820 & 21,187 & 26,636 & 32,456 & 33,881 & 34,738 & 35,123 \\
\hline Wirt & 1,592 & 4,193 & 4,913 & 6,182 & 6,241 & 5,790 & 6,272 \\
\hline Wod & 27,800 & 84,307 & 107,819 & 132,913 & 132,551 & 138,342 & 146,765 \\
\hline Tyoming & 10,975 & 32,443 & 40,600 & 51,002 & 45,174 & 44,489 & 46,100 \\
\hline TOTAL & 760,391 & $2,207,000$ & $2,586,000$ & $3,091,000$ & $2,972,000$ & $3,053,000$ & $3,142,001$ \\
\hline
\end{tabular}


TABLE 1B. PERSONAL INCOMES (IN THOUSANDS OF DOLLARS, ADJUSTED BY THE WHOLESALE COMMODITY INDEX) FOR THE COUNTIES OF WEST VIRGINIA

The information presented in this table is based upon data published by the West Virginia Chamber of Commerce, as indicated in the preceding table, Table $1 \mathrm{~A}$, Section VIII.

\begin{tabular}{|c|c|c|c|c|c|c|c|}
\hline COUNTY & 1940 & 1950 & 1955 & 1957 & 1958 & 1959 & 1960 \\
\hline Barbour & 11,781 & 18,376 & 18,922 & 20,239 & 19,697 & 20,162 & 20,749 \\
\hline Berkeley & 25,718 & 39,744 & 44,852 & 46,523 & 47,871 & 51,552 & 53,317 \\
\hline Boone & 18,434 & 30,342 & 32,238 & 36,798 & 32,911 & 32,667 & 33,356 \\
\hline Braxton & 9,012 & 14,103 & 16,118 & 18,399 & 18,451 & 17,864 & 16,547 \\
\hline Brooke & 25,284 & 33,334 & 37,844 & 38,638 & 37,399 & 37,515 & 39,134 \\
\hline Cabell & 85,519 & 136,324 & 149,740 & 169,269 & 163,061 & 170,988 & 175,711 \\
\hline Cathoun & 5,333 & 6,410 & 6,541 & 7,622 & 7,480 & 7,657 & 7,879 \\
\hline Clay & 7,975 & 11,966 & 12.848 & 13,142 & 12,217 & 11,740 & 11.556 \\
\hline Doddridge & 5,364 & 7.479 & 6,774 & 7,097 & 7.480 & 7.401 & 8,142 \\
\hline Fayetre & 68,544 & 89.744 & 87,135 & 89,366 & 82,279 & 83,709 & 85,623 \\
\hline Gilmer & 5,323 & 7.479 & 7.242 & 7.885 & -7.978 & 8,678 & 9,193 \\
\hline Grant & 4.932 & 10,470 & 11,680 & 13,142 & 12.965 & 13,526 & 13,395 \\
\hline Greenbrier & 24,012 & 36,538 & 39,012 & 43.895 & 41,888 & 42,364 & 43,074 \\
\hline Hampshire & 7.067 & 12,179 & 13,549 & 14,193 & 13,464 & 14,547 & 14,971 \\
\hline Hancock & 54,716 & 50,214 & 58,634 & 65,973 & 63,828 & 73.755 & 76,430 \\
\hline Hardy & 6,243 & 13,034 & 13,549 & 14.457 & 13,713 & 14,547 & 14,971 \\
\hline Harrison & 64,971 & 106,838 & 112,130 & 126,164 & 120,924 & 120,969 & 123,707 \\
\hline Jackson & 8,008 & 14,530 & 17,987 & 47,311 & 29,919 & 35,219 & 36,771 \\
\hline Jefferson & 10,920 & 17.735 & 21.491 & 21,815 & 22,190 & 26,796 & 29,154 \\
\hline Kanawha & 190,431 & 289,957 & 339,427 & 382,955 & 371,750 & 392,253 & 402,128 \\
\hline Lewis & 12,607 & 17,735 & 18.454 & 18.399 & 18,700 & 19,395 & 19,698 \\
\hline Lincoln & 8,395 & 13,462 & 16,352 & 18,399 & 17,204 & 17,099 & 17,860 \\
\hline Logao & 56,546 & 85,684 & 89,004 & 105,924 & 92,252 & 88,812 & 89,563 \\
\hline McDowell & 97,025 & 101,710 & 93,909 & 96,725 & 84,772 & 79,880 & 77,481 \\
\hline Marion & 59,266 & 82,593 & 86,434 & 98,039 & 97,487 & 97,234 & 100,856 \\
\hline Marshall & 31,452 & 47,436 & 58,401 & 62,819 & 64,826 & 63,802 & 66,450 \\
\hline Mason & 10,959 & 26,282 & 32,705 & 35,220 & 35,404 & 36,240 & 38,872 \\
\hline Mercer & 56,497 & 78,632 & 84,799 & 94,622 & 89,260 & 85,240 & 86,410 \\
\hline Mioeral & 12,916 & 15,171 & 17,053 & 19,713 & 20,695 & 26,311 & 28,385 \\
\hline Miogo & 26,340 & 45,941 & 50,692 & 47,837 & 42,386 & 40,323 & 39,660 \\
\hline Mooongalia & 45,205 & 67,094 & 74,753 & 82,269 & 77,292 & 79,115 & 79,582 \\
\hline Monroe & 6,403 & 11,753 & 11,914 & 13,142 & 13,713 & 12,760 & 13,132 \\
\hline Morgan & 6,425 & 9,188 & 10,746 & 11,565 & 11,220 & 11,994 & 11,819 \\
\hline Nicholas & 11,626 & 25,213 & 28,500 & 32,329 & 28,424 & 28,839 & 30,204 \\
\hline Ohio & 81,840 & 106,197 & 119,138 & 132,735 & 126,659 & 130,922 & 139,728 \\
\hline Pendletoo & 5,157 & 6,838 & 8,410 & 9,200 & 9,225 & 10,719 & 10,506 \\
\hline Pleasants & 4,642 & 5,983 & 7,475 & 8,936 & 8,976 & 8,932 & 9,193 \\
\hline Pocahontas & 8,928 & 10,897 & 11,680 & 13,405 & 11,968 & 13,015 & 13,131 \\
\hline Preston & 16,070 & 28,632 & 24,995 & 28,912 & 26,429 & 26,796 & 27,574 \\
\hline Putoam & 12,168 & 16,881 & 22,192 & 28,124 & 26,678 & 31,391 & 29,679 \\
\hline Raleigh & 78,438 & 94,231 & 93,442 & 114,861 & 105,216 & 99,531 & 102,432 \\
\hline Randolph & 17.967 & 24,573 & 25,930 & 28,912 & 28,673 & 29,859 & 31,518 \\
\hline Ritchie & 7.750 & 10,256 & 11,213 & 12,091 & 11,718 & 11,740 & 12,607 \\
\hline Rosoe & 9,638 & 13,462 & 15,418 & 17,348 & 17,453 & 17,864 & 19,173 \\
\hline Summers & 12,290 & 16,881 & 16.819 & 18,136 & 16,955 & 17,610 & 17,860 \\
\hline Taylor & 12.763 & 15,385 & 16,352 & 18,136 & 16.456 & 16,333 & 16,022 \\
\hline Tucker & 7.613 & 8,760 & 8.410 & 8,936 & 8,727 & 8,932 & 9,456 \\
\hline Tyler & 6,636 & 7,906 & 8,877 & 9,463 & 10,222 & 9,698 & 10,507 \\
\hline Upshar & 8,380 & 15,598 & 16,352 & 18.399 & 17,204 & 17,354 & 18,385 \\
\hline Wayoe & 14,129 & 25,213 & 31,070 & 33,644 & 32,164 & 33,687 & 37,034 \\
\hline Webster & 10,049 & 16,666 & 14,717 & 16,033 & 14,711 & 14,547 & 14,709 \\
\hline Wetzel & 13,346 & 20,513 & 24,061 & 27,599 & 28,424 & 29,094 & 29,416 \\
\hline Wirt & 3,115 & 4,060 & 4,438 & 5,257 & 5,236 & 4,849 & 5,253 \\
\hline Wood & & 81,625 & 96,946 & 113,021 & 111,201 & 115,864 & 919 \\
\hline Wyoming & 21,477 & 31,410 & 36,676 & 43,369 & 37,898 & 37,260 & 38,610 \\
\hline TOTAL & 1488,045 & $2,136,760$ & $2,336,043$ & 2628,401 & $24+93,289$ & $2,256,950$ & $2,631,492$ \\
\hline
\end{tabular}

Section V III ECONOMIC ACTIVITIES

W. Va. Univ.

Agr. Exp. Sta.

Bul. No. 464 
TABLE 1C. INDEX OF ADJUSTED PERSONAL INCOME FOR THE COUNTIES OF WEST VIRGINIA, $1950=100$

This index was prepared from data presented in the preceding table, Table 1B, Section VIII.

Section V III

ECONOMIC

ACTIVITIES
W. Vo. Univ. Agr. Exp. Sta. Bul. No. 464

Page 90

\begin{tabular}{|c|c|c|c|c|c|c|c|}
\hline COUNTY & 1940 & 1950 & 1955 & 1957 & 1958 & 1959 & 1960 \\
\hline Barbour & 64.1 & 100.0 & 103.0 & 110,1 & 107.2 & 109.7 & 112.9 \\
\hline Berkeley & 64.7 & 100.0 & 112.9 & 117.1 & 120.4 & 129.7 & 134.2 \\
\hline Boone & 60.8 & 100.0 & 106.2 & 121.3 & 108.5 & 107.7 & 109.9 \\
\hline Braxton & 63.9 & 100.0 & 114.3 & 130.5 & 130.8 & 126.7 & 117.3 \\
\hline Brooke & 75.8 & 100.0 & 113.5 & 115.9 & 112.2 & 112.5 & 117.4 \\
\hline Cabell & 62.7 & 100.0 & 109.4 & 124.2 & 119.6 & 125.4 & 128.9 \\
\hline Calhoun & 83.2 & 100.0 & 102.0 & 118.9 & 116.7 & 119.5 & 122.9 \\
\hline Clay & 66.6 & 100.0 & 107.4 & 109.8 & 202.1 & 98.1 & 96.6 \\
\hline Doddridge & 71.7 & 100.0 & 90.6 & 94.9 & 100.0 & 99.0 & 108.9 \\
\hline Fayette & 76.4 & 100.0 & 97.1 & 99.6 & 91.7 & 93.3 & 95.4 \\
\hline Gilmer & 71.2 & 100.0 & 96.8 & 105.4 & 106.7 & 116.0 & 122.9 \\
\hline Grant & 47.1 & 100.0 & 111.6 & 125.5 & 123.8 & 129.2 & 127.9 \\
\hline Greenbrier & 65.7 & 100.0 & 106.8 & 120.1 & 114.6 & 115.9 & 117.9 \\
\hline Hampshire & 58.0 & 100.0 & 111.2 & 116.5 & 110.6 & 119.4 & 122.9 \\
\hline Hancock & 109.0 & 100.0 & 116.8 & 131.4 & 127.1 & 146.9 & 152.2 \\
\hline Hardy & 47.9 & 100.0 & 104.0 & 110.9 & 105.2 & 111.6 & 114.9 \\
\hline Harrisoo & 60.8 & 100.0 & 105.0 & 118.1 & 113.2 & 113.2 & 115.8 \\
\hline Jackson & 55.1 & 100.0 & 123.8 & 325.6 & 205.9 & 242.4 & 253.1 \\
\hline Jeffersoo & 61.6 & 100,0 & 121.2 & 123.0 & 125.1 & 151.1 & 164.4 \\
\hline Kanawha & 65.7 & 100.0 & 117.1 & 132.1 & 128.2 & 135.3 & 138.7 \\
\hline Lewis & 71.1 & 100,0 & 104.1 & 103.7 & 105.4 & 109.4 & 111.1 \\
\hline Lincolo & 62.4 & 100.0 & 121.5 & 136.7 & 127.8 & 127.0 & 132.7 \\
\hline Logao & 66.0 & 100.0 & 103.9 & 123.6 & 107.7 & 103.6 & 104.5 \\
\hline McDowell & 95.4 & 100.0 & 92.3 & 95.1 & 83.3 & 78.5 & 76.2 \\
\hline Marioo & 71.7 & 100.0 & 103.3 & 118.6 & 117.9 & 117.6 & 122.0 \\
\hline Marshall & 66.3 & 100.0 & 123.1 & 132.4 & 136.7 & 134.5 & 140.1 \\
\hline Masoo & 41.7 & 100.0 & 124.4 & 134.0 & 134.7 & 137.9 & 147.9 \\
\hline Mercex & 71.8 & 100.0 & 107.8 & 120.3 & 113.5 & 108.4 & 109.9 \\
\hline Mineral & 85.1 & 100.0 & 112.4 & 129.9 & 136.4 & 173.4 & 187.1 \\
\hline Mingo & 57.3 & 100.0 & 110.3 & 104.1 & 92.3 & 87.8 & 86.3 \\
\hline Monongalia & 67.4 & 100.0 & 111.4 & 122.6 & 115.2 & 117.9 & 118.6 \\
\hline Mooroe & 54.5 & 100.0 & 101.4 & 111.8 & 116.7 & 108.6 & 111.7 \\
\hline Morgan & 69.9 & 100.0 & 117.0 & 125.9 & 122.1 & 130.5 & 128.6 \\
\hline $\begin{array}{l}\text { Nicholas } \\
\end{array}$ & $46 . .1$ & 100.0 & 113.0 & 128.2 & 112.7 & $11 \overline{4.4}$ & 119.8 \\
\hline Ohio & 77.1 & 100.0 & 112.2 & 125.0 & 119.3 & 123.3 & 131.6 \\
\hline Pendletoo & 75.4 & 100.0 & 123.0 & 134.5 & 134.9 & 156.8 & 153.6 \\
\hline Pleasants & 77.6 & 100.0 & 124.9 & 149.4 & 150.0 & 149.3 & 153.7 \\
\hline Pocahootas & 81.9 & 100.0 & 107.2 & 123.0 & 109.8 & 119.4 & 120.5 \\
\hline Prestoo & 56.1 & 100,0 & 87.3 & 101.0 & 92.3 & 93.6 & 96.3 \\
\hline Putoam & 72.1 & 100.0 & 131.5 & 166.6 & 158.0 & 186.0 & 175.8 \\
\hline Raleigh & 83.2 & 100.0 & 99.2 & 121.9 & 111.7 & 105.6 & 108.7 \\
\hline Randolph & 73.1 & 100.0 & 105.5 & 117.7 & 116.7 & 121.5 & 128.3 \\
\hline Ritchie & 75.6 & 100.0 & 109.3 & 117.9 & 114.3 & 114.5 & 122.9 \\
\hline Roaoe & 21.6 & 100.0 & 114.5 & 128.9 & 129.6 & 132,7 & 142,4 \\
\hline Sommers & 72.8 & 100.0 & 99.6 & 107.4 & 100.4 & 104.3 & 105.8 \\
\hline Taylor & 83.0 & 100.0 & 106.3 & 117.9 & 107.0 & 106.2 & 104.1 \\
\hline Tuckex & 86.9 & 100.0 & 96.0 & 102.0 & 99.6 & 102.0 & 107.9 \\
\hline Tyler & 83.9 & 100.0 & 112.3 & 119.7 & 129.3 & 122.7 & 132.9 \\
\hline Upshur & 53.7 & 100.0 & 104.8 & 118.0 & 110.3 & 111.3 & 117.9 \\
\hline Wayoe & 56.0 & 100.0 & 123.2 & 133.4 & 127.6 & 133.6 & 146.9 \\
\hline Webster & 60.3 & 100.0 & 88.3 & 96.2 & 88.3 & 87.3 & 88.3 \\
\hline Wetze! & 65.1 & 100.0 & 117.3 & 134.5 & 138.6 & 141.8 & 143.4 \\
\hline Wirt & 76.7 & 100.0 & 109.3 & 129.5 & 129.0 & 119.4 & 129.4 \\
\hline Wood & 66.6 & 100.0 & 118.8 & 138.5 & 136.2 & 141.9 & 150.6 \\
\hline Wyoming & 68.4 & 100.0 & 116.8 & 138.1 & 120.7 & 118.6 & 122.9 \\
\hline TOTAL & 69.6 & 100.0 & 109.3 & 123.0 & 116.7 & 119.7 & 123.2 \\
\hline
\end{tabular}


TABLE ID. THE PERSONAL INCOME OF EACH OF THE COUNTIES OF WEST VIRGINIA, REPRESENTED AS A PERCENTAGE (IN THOUSANDTHS

OF 1 PER CENT) OF THE NATIONAL INCOME

These data are based upon those data presented in Table 1A, Section VIII, and data taken from Statistical Abstracts of the United States.

\begin{tabular}{|c|c|c|c|c|c|c|c|}
\hline COUNTY & 1940 & 1950 & 1955 & 1957 & 1958 & 1959 & 1960 \\
\hline Barbour & 7.7 & 8.3 & 6.8 & 6.8 & 6.5 & 6.3 & 6.1 \\
\hline Berkeley & 16.7 & 18.0 & 16.0 & 15.6 & 15.9 & 16.1 & 15.7 \\
\hline Boone & 12.0 & 13.7 & 11.5 & 12.3 & 10.9 & 10.2 & 9.9 \\
\hline Braxton & 5.9 & 6.4 & 5.8 & 6.2 & 6.1 & 5.6 & 4.9 \\
\hline Bronke & 16.4 & 15.1 & 13.5 & 13.0 & 12.4 & 11.7 & 11.6 \\
\hline Cabell & 55.5 & 61.6 & 53.4 & 56.8 & 54.1 & 53.3 & 51.9 \\
\hline Calhouo & 3.5 & 2.9 & 2.3 & 2.6 & 2.5 & 2.4 & 2.3 \\
\hline Clay & 5.2 & 5.4 & 4.6 & 4.4 & 4.1 & 3.7 & 3.4 \\
\hline Doddridge & 3.5 & 3.4 & 2.4 & 2.4 & 2.5 & 2.3 & 2.4 \\
\hline Fayette & 44.5 & 40.6 & 31.1 & 30.0 & 27.3 & 26.1 & 25.3 \\
\hline Gilmer & 3.5 & 3.4 & 2.6 & 2.6 & 2.6 & 2.7 & 2.7 \\
\hline Grant & 3.2 & 4.7 & 4.2 & 4.4 & 4.3 & 4.2 & 4,0 \\
\hline Greenhrier & 15.6 & 16.5 & 13.9 & 14.7 & 13.9 & 13.2 & 12.7 \\
\hline Hampshire & 4.6 & 5.5 & 4.8 & 4.8 & 4.5 & 4.5 & 4.4 \\
\hline Hancnck & 35.5 & 22.7 & 20.9 & 22.1 & 21.2 & 23.0 & 22.6 \\
\hline Hardy & 4.1 & 5.9 & 4.8 & 4.8 & 4.6 & 4.5 & 4.4 \\
\hline Harrisoo & 42.2 & 48.3 & 40.0 & 42.3 & 40.1 & 37.7 & 36.5 \\
\hline Jackson & 5.2 & 6.6 & 6.4 & 15.9 & 9.9 & 11.0 & 10.9 \\
\hline Jefferson & 7.1 & 8.0 & 7.7 & 7.3 & 7.4 & 8.3 & 8.6 \\
\hline Kanawha & 123.7 & 131.1 & 121.1 & 128.5 & 123.4 & 122.2 & 118.8 \\
\hline Lewis & 8.2 & 8.0 & 6.6 & 6.2 & 6.2 & 6.0 & 5.8 \\
\hline Liocolo & 5.5 & 6.1 & 5.8 & 6.2 & 5.7 & 5.3 & 5.3 \\
\hline Logan & 36.7 & 38.7 & 31.8 & 35.5 & 30.6 & 27.7 & 26.5 \\
\hline McDowell & 63.0 & 46.0 & 33.5 & 32.4 & 28.1 & 24.9 & 22.9 \\
\hline Marion & 38.5 & 37.4 & 30.8 & 32.9 & 32.4 & 30.3 & 29.8 \\
\hline Marshall & 20.4 & 21.4 & 20.8 & 21.1 & 21.5 & 19.9 & 19.6 \\
\hline Mason & 7.1 & 11.9 & 11.7 & 11.8 & 11.8 & 11.3 & 11.5 \\
\hline Mercer & 36.7 & 35.5 & 30.3 & 31.7 & 29.6 & 26.6 & 25.5 \\
\hline Mineral & 8.4 & 6.9 & 6.1 & 6.6 & 6.9 & 8.2 & 8.4 \\
\hline Mingo & 17.1 & 20.8 & 18.1 & 16.0 & 14.1 & 12.6 & 11.7 \\
\hline Moooogalia & 29.4 & 30.3 & 26.7 & 27.6 & 25.7 & 24.6 & 23.5 \\
\hline Monroe & 4.2 & 5.3 & 4.3 & 4.4 & 4.6 & 4.0 & 3.9 \\
\hline Morgan & 4.2 & 4.2 & 3.8 & 3.9 & 3.7 & 3.7 & 3.5 \\
\hline Nicholas & 7.6 & 11.4 & 10.2 & 10.8 & 9.4 & 9.0 & 8.9 \\
\hline Ohio & 53.2 & 48.0 & 42.5 & 44.5 & 42.0 & 40.8 & 41.3 \\
\hline Pendletnn & 3.3 & 3,1 & 3.0 & 3.1 & 3.1 & 3.4 & 3,1 \\
\hline Pleasaots & 3.0 & 2.7 & 2.7 & 3.0 & 3.0 & 2.8 & 2.7 \\
\hline Pocahontas & 5.8 & 4.9 & 4.2 & 4.5 & 4.0 & 4.1 & 3.9 \\
\hline Preston & 10.4 & 12.9 & 8.9 & 9.7 & 8.8 & 8.3 & 8.1 \\
\hline Putnam & 7.9 & 7.6 & 7.9 & 9.4 & 8.9 & 9.8 & 8.8 \\
\hline Raleigh & 50.9 & 42.6 & 33.3 & 38.5 & 34.9 & 31.0 & 30.3 \\
\hline Raodolph & 11.7 & 11.1 & 9.3 & 9.7 & 9.5 & 9.3 & 9.3 \\
\hline Ritchie & 5.0 & 4.6 & 4.0 & 4.1 & 3.9 & 3.7 & 3.7 \\
\hline Roane & 6.3 & 6.1 & 5,5 & 5.8 & 5.8 & 5.6 & 5.7 \\
\hline Summers & 8.0 & 7.6 & 6.0 & 6.1 & 5.6 & 5.5 & 5.3 \\
\hline Taylor & 8.3 & 7.0 & 5.8 & 6.1 & 5.5 & 5.1 & 4.7 \\
\hline Tucker & 4.9 & 4.0 & 3.0 & 3.0 & 2.9 & 2.8 & 2.8 \\
\hline Tylet & 4.3 & 3.6 & 3.2 & 3.2 & 3.4 & 3.0 & 3.1 \\
\hline Upshur & 5.4 & 7.1 & 5.8 & 6.2 & 5.7 & 5.4 & 5.4 \\
\hline Wayce & 9.2 & 11.4 & 11.1 & 11.3 & 10.7 & 10.5 & 10.9 \\
\hline Webster & 6.5 & 7.5 & 5.3 & 5.4 & 4.9 & 4.5 & 4.3 \\
\hline Wetzel & 8.7 & 9.3 & 8.6 & 9.3 & 9.4 & 9.1 & 8.7 \\
\hline Wirt & 2.0 & 1.8 & 1.6 & 1.8 & 1.7 & 1.5 & 1.6 \\
\hline Wood & 5,3 & & & 37.9 & 30.9 & 6.1 & \\
\hline Wyoming & 13.9 & 14.2 & 13.1 & 14.5 & 12.6 & $11: 6$ & 11.4 \\
\hline TOTAL & 966.4 & 966.0 & 833.7 & 881.7 & 827.8 & 796.5 & 777.3 \\
\hline
\end{tabular}

Section V III ECONOMIC ACTIVITIES

W. Va. Univ. Agr. Exp. Sta. Bul. No. 464

Page 91 
These data are based upon the estimates of the West Virginia Chamber of Commerce as published in Personal Income and Retail Sales in West Virginia by Counties for 1958 and other years. As this publication indicates, estimates of West Virginia retail sales are based laregly on reports of collections from the State's Consumer Sales Tax. It should be pointed out that retail sales are associated to a considerable extent with the business districts of towns and cities. County and state boundary lines may be ignored by retail customers when distances to retail centers are shorter or where the variety of offering is greater.
Section V III ECONOMIC ACTIVITIES

W. Ya. Univ. Agr. Exp. Sta. Bul. No. 464

Page 92

\begin{tabular}{|c|c|c|c|c|c|c|c|}
\hline COUNTY & 1940 & 1950 & 1955 & 1957 & 1958 & 1959 & 1960 \\
\hline Barbour & 2,331 & 6,451 & 7,167 & 8,477 & 8,225 & 8,960 & 9,266 \\
\hline Berkeley & 7,039 & 21,631 & 26,913 & 29,583 & 30,268 & 30,669 & 32,254 \\
\hline Boone & 4,708 & 15,307 & 16,736 & 20,241 & 17,272 & 19,642 & 20,493 \\
\hline Braxton & 2,068 & 6,452 & 8,568 & 11,072 & 10,857 & 10,166 & 9,445 \\
\hline Brooke & 4,400 & 12,777 & 16,766 & 17,473 & 16.779 & 19,298 & 20,137 \\
\hline Cabell & 34,750 & 109,548 & 126,803 & 150,856 & 145,418 & 165,753 & 169,468 \\
\hline Calhoun & 1,066 & 2,277 & 2,671 & 3,460 & 3,454 & 3,791 & 3,920 \\
\hline Clay & 1,408 & 4,048 & 3,843 & 4.325 & 3,948 & 4,824 & 4,811 \\
\hline Doddridge & 1,144 & 3,162 & 3,384 & 3,979 & 4,277 & 4,997 & 5,346 \\
\hline Fayette & 19,052 & 48,070 & 43,828 & 47,056 & 43,099 & 48,072 & 49,540 \\
\hline Gilmer & 942 & 2,530 & 2,780 & 3,633 & 3,619 & 3,618 & 3,921 \\
\hline Grant & 1,276 & 6,072 & 6,830 & 8,304 & 8,225 & 8,098 & 8,375 \\
\hline Greenbrier & 7,125 & 25,047 & 28,946 & 34,600 & 32,900 & 33,082 & 33,323 \\
\hline Hampshire & 1,584 & 5,313 & 6,874 & 7,785 & 7,402 & 8,960 & 9,266 \\
\hline Hancock & 7,260 & 20,113 & 24,911 & 29,929 & 28,787 & 34,288 & 35,818 \\
\hline Hardy & 1,188 & 4,934 & 7,043 & 8,304 & 7,896 & 8,960 & 9,445 \\
\hline Harrison & 22,435 & 72,357 & 74,042 & 88,057 & 84,553 & 85,116 & 87,853 \\
\hline Jackson & 1,892 & 6,705 & 8,611 & 14,532 & 13,654 & 12,922 & 13,543 \\
\hline Jefferson & 2,729 & 10,120 & 14,523 & 15,397 & 15,463 & 17,919 & 19,424 \\
\hline Kanawha & 68,330 & 208,724 & 254,645 & 303,096 & 293,304 & 310,657 & 320,937 \\
\hline Lewis & 3,829 & 10,879 & 11,398 & 12,629 & 12,831 & 15.335 & 16,038 \\
\hline Lincoln & 1,540 & 5,819 & 7,323 & 8,996 & 8,390 & 7,581 & 7,841 \\
\hline Logan & 16,246 & 48,450 & 42,772 & 53,803 & 45,731 & 48,244 & 47,579 \\
\hline McDowell & 24.872 & 50,221 & 52,552 & 56.917 & 48,034 & 47,210 & 45,976 \\
\hline Marion & 18,612 & 47.817 & 55,175 & 66,951 & 66,787 & 62,889 & 64,687 \\
\hline Marshall & 6,071 & 17,330 & 19.417 & 22,144 & 22.866 & 26,362 & 27,443 \\
\hline Mason & 2,069 & 9,867 & 12,893 & 14,013 & 14,147 & 13,784 & 15,147 \\
\hline Mercer & 18,435 & 52,877 & 59,936 & 71,795 & 67,610 & 64,268 & 66,112 \\
\hline Mineral & 4.180 & 9,488 & 11,884 & 14,705 & 15,463 & 13,956 & 15,682 \\
\hline Mingo & 8,581 & 30,107 & 32,767 & 32,697 & 28,294 & 32,909 & 32,611 \\
\hline Mnnongalia & 14,696 & 43,515 & 47,588 & 55,533 & 51,982 & 51,001 & 51,856 \\
\hline Manroe & 1,189 & 4,175 & 4.891 & 6.055 & 6,251 & 5,169 & 5,524 \\
\hline Morgan & 1,012 & 2,910 & 3,442 & 3,979 & 3,784 & 5,341 & 5,346 \\
\hline Nicbolas & 2,331 & 12,271 & 15,519 & 19.203 & 16,779 & 18,264 & 19,246 \\
\hline Ohio & 34,594 & 85,387 & 106,666 & 120,754 & 115,479 & 113,373 & 122,067 \\
\hline Pendleton & 1,012 & 2.783 & 3,933 & 3,979 & 4,112 & 4,480 & 4,455 \\
\hline Pleasants & 1.320 & 3,415 & 4,686 & 5,882 & 5,922 & 6,030 & 6,237 \\
\hline Pocahontas & 1,891 & 4,681 & 6,198 & 7,958 & 6,909 & 6,547 & 6,772 \\
\hline Prestas & 3,742 & 12,903 & 12,573 & 15,570 & 14,147 & 13,956 & 14,612 \\
\hline Pntaam & 2,421 & 5,566 & 8,538 & 11,591 & 10,857 & 11,889 & 11,227 \\
\hline Raleigh & 23,071 & 53,636 & 52,184 & 68,681 & 63,004 & 63,062 & 64,687 \\
\hline Rasdolph & 6,118 & 16,445 & 18,678 & 22,490 & 22,372 & 22,227 & 23,522 \\
\hline Ritchie & 1,849 & 4.807 & 5,860 & 7,093 & 6,909 & 6,892 & 7,484 \\
\hline Roane & 2.288 & 6,578 & 7,500 & 8,823 & 8,883 & 9,304 & 9,979 \\
\hline Summers & 2,945 & 7.843 & 9,108 & 10,899 & 10,199 & 11,716 & 12,118 \\
\hline Taylor & 3,472 & 8,223 & 9,789 & 11,591 & 10,528 & 11,889 & 11,761 \\
\hline Tucker & 1,803 & 3,542 & 4,238 & 4,671 & 4,606 & 5,169 & 5,524 \\
\hline Tyler & 1,801 & 4,048 & 6.281 & 7,093 & 7,567 & 6,892 & 7,663 \\
\hline Upshur & 2,640 & 9,994 & 12,194 & 14,705 & 13,818 & 13,784 & 14,612 \\
\hline Wayne & 2,288 & 8,349 & 12,035 & 14,013 & 13,324 & 15,679 & 16,751 \\
\hline Webscer & 2,198 & 6,958 & 7,293 & 8,996 & 8,225 & 8.270 & 8,197 \\
\hline Wetzel & 3,650 & 10.879 & 14,613 & 18,684 & 18,918 & 18,264 & 18,355 \\
\hline Wirt & 484 & 1,139 & 1,198 & 1,557 & 1,480 & 1,551 & 1,782 \\
\hline Wood & 18,501 & & 64,858 & 87,365 & 85,540 & 95,454 & 100,683 \\
\hline Wyoming & 5,539 & 15,053 & 21,039 & 28,026 & 23,852 & 24,467 & 25,839 \\
\hline TOTAL & 439,999 & $1,265,000$ & $1,452,903$ & $1,730,000$ & $1,645,000$ & 723,000 & 1782,000 \\
\hline
\end{tabular}


The data presented here are based upon the information presented in the preceding table, Table $2 \mathrm{~A}$, Section VIII.

\begin{tabular}{|c|c|c|c|c|c|c|c|}
\hline COUNTY & 1940 & 1950 & 1955 & 1957 & 1958 & 1959 & 1960 \\
\hline Barbour & 4,562 & 6,257 & 6,474 & 7,208 & 6,900 & 7,504 & 7,760 \\
\hline Berkeley & 13,775 & 20,980 & 24,312 & 25,156 & 25,393 & 25,686 & 27,013 \\
\hline Boone & 9,213 & 14,847 & 15,118 & 17,212 & 14,490 & 16,451 & 17,163 \\
\hline Braxton & 4.047 & 6.258 & 7,740 & 9,415 & 9.108 & 8,514 & 7,910 \\
\hline Brooke & 8.611 & 12,393 & 15,145 & 14,858 & 14,076 & 16,162 & 16,865 \\
\hline Cabell & 68,004 & 106,254 & 114,547 & 128,279 & 121,995 & 138,822 & 141,934 \\
\hline Calhoua & 2,086 & 2,209 & 2,413 & 2,942 & 2,898 & 3,175 & 3,283 \\
\hline Clay & 2,755 & 3,926 & 3,472 & 3,678 & 3,312 & 4,040 & 4,029 \\
\hline Doddridge & 2,239 & 3,067 & 3,057 & 3,384 & 3,588 & 4,185 & 4,477 \\
\hline Fayette & 37,284 & 46,625 & 39,592 & 40,014 & 36,157 & 40,261 & 41,491 \\
\hline Gilmer & 1,843 & 2,454 & 2,511 & 3,089 & 3,036 & 3,030 & 3,284 \\
\hline Grant & 2,497 & 5,889 & 6,170 & 7.061 & 6.900 & 6,782 & 7,014 \\
\hline Greenbrier & 13,943 & 24,294 & 26,148 & 29,422 & 27,601 & 27,707 & 27,909 \\
\hline Hampshire & 3,100 & 5,153 & 6,210 & 6,620 & 6,210 & 7,504 & 7,760 \\
\hline Haocock & 14,207 & 19,508 & 22,503 & 25,450 & 24,150 & 28,717 & 29,998 \\
\hline Hardy & 2.325 & 4.786 & 6,362 & 7,061 & 6,624 & 7,504 & 7,910 \\
\hline Harrison & 43,904 & 70,181 & 66,885 & 74,878 & 70,934 & 71,286 & 73,579 \\
\hline Jackson & 3,703 & 6,503 & 7,779 & 12,357 & 11,455 & 10,822 & 11,343 \\
\hline Jefferson & 5,340 & 9.816 & 13,119 & 13,093 & 12,972 & 15,008 & 16,268 \\
\hline Kanawha & 133,718 & 202,448 & 230,031 & 257,735 & 246,060 & 260,182 & 268,792 \\
\hline Lewis & 7.493 & 10,552 & 10,296 & 10,739 & 10,764 & 12,843 & 13,432 \\
\hline Lincoln & 3,014 & 5,644 & 6.615 & 7,650 & 7,039 & 6,349 & 6,567 \\
\hline Logan & 31,793 & 46,993 & 38,638 & 45,751 & 38,365 & 40,405 & 39,848 \\
\hline McDowell & 48,673 & 48,711 & 47,472 & 48,399 & 40,297 & 39,539 & 38,506 \\
\hline Marion & 36,423 & 46,379 & 49,842 & 56,931 & 56,029 & 52,671 & 54,177 \\
\hline Marshall & 11,881 & 16,809 & 17,540 & 18,830 & 19,183 & 22,079 & 22,984 \\
\hline Masno & 4,049 & 9.570 & 11,647 & 11,916 & 11,868 & 11,544 & 12,686 \\
\hline Mercer & 36,076 & 51,287 & 54,143 & 61,050 & 56,720 & 53,826 & 55,370 \\
\hline Mineral & 8,180 & 9,203 & 10,735 & 12,504 & 12,972 & 11,688 & 13,134 \\
\hline Mingo & 16,793 & 29,202 & 29,600 & $27,8 \overline{04}$ & 23,737 & 27,562 & 27,312 \\
\hline Monongalia & 28,759 & 42,207 & 42,988 & 47,222 & 43,609 & 42,714 & 43,430 \\
\hline Monroe & 2,327 & 4,049 & 4,418 & 5,149 & 5,244 & 4,329 & 4,626 \\
\hline Morgan & 1,980 & 2,823 & 3,109 & 3,384 & 3,174 & 4,473 & 4,477 \\
\hline Nicholas & 4.562 & 11,902 & 14,019 & 16,329 & 14,076 & 15,296 & 16,119 \\
\hline Ohio & 67,699 & 82,820 & 96,356 & 102,682 & 96,878 & 94,952 & 102,235 \\
\hline Peadleton & 1,980 & 2.699 & 3,553 & 3,384 & 3,450 & 3,752 & 3,731 \\
\hline Pleasants & 2,583 & 3,312 & 4,233 & 5.002 & 4,968 & 5,050 & 5,224 \\
\hline Pocahontas & 3,701 & 4.540 & 5,599 & 6.767 & 5,796 & 5,483 & 5,672 \\
\hline Preston & 7,323 & 12,515 & 11,358 & 13,240 & 11,868 & 11,688 & 12,238 \\
\hline Putnam & 4.738 & 5,399 & 7,713 & 9.856 & 9,108 & 9,957 & 9,403 \\
\hline Raleigh & 45,149 & 52.023 & 47,140 & 58.402 & 52.856 & 52.816 & 54,177 \\
\hline Randolph & 11,973 & 15,951 & 16,873 & 19,124 & 18,768 & 18,616 & 19,700 \\
\hline Ritchie & 3,618 & 4,662 & 5,294 & 6,031 & 5,796 & 5,772 & 6,268 \\
\hline Roane & 4,477 & 6,380 & 6,775 & 7,503 & 7,452 & 7,792 & 8,358 \\
\hline Summers & 5,763 & 7,607 & 8,228 & 9,268 & 8,556 & 9,812 & 10,149 \\
\hline Taylor & 6.795 & 7.976 & 8,843 & 9.856 & 8,832 & 9.957 & 9.850 \\
\hline Tucker & 3,528 & 3,435 & 3,828 & 3,972 & 3,864 & 4,329 & 4,626 \\
\hline Tyler & 3,524 & 3,926 & 5,674 & 6,031 & 6,348 & 5,772 & 6,418 \\
\hline Upshur & 5,166 & 9,694 & 11,015 & 12,504 & 11,592 & 11,544 & 12,238 \\
\hline Wayne & 4.477 & 8,098 & 10,872 & 11,916 & 11,178 & 13,131 & 14,029 \\
\hline Webster & 4,301 & 6.749 & 6,588 & 7.650 & 6,900 & 6,926 & 6,865 \\
\hline Weizel & 7.143 & 10,552 & 13,201 & 15,888 & 15,871 & 15,296 & 15,373 \\
\hline Wirt & 947 & 1,105 & 1,082 & 1,324 & 1,242 & 1,299 & 1,492 \\
\hline Wood & 36,205 & 53.741 & 58.589 & 74,290 & 71,762 & 79.945 & 84,324 \\
\hline Wyomiag & 10,840 & 14,600 & 19,005 & 23,832 & 20,010 & 20,492 & 21,641 \\
\hline TOTAL & 861.055 & 1.226 .964 & $1,312,469$ & $1,471,088$ & $1,380,034$ & $1,443,049$ & $1,492,461$ \\
\hline
\end{tabular}

Section V III ECONOMIC ACTIVITIES

W. Va. Univ. Agr. Exp. Sta.

Bul. No. 464 
TABLE 2C. INDEX TO ADJUSTED RETAIL SALES FOR THE COUNTIES

OF WEST VIRGINIA, $1950=100$

The data presented in this table are based upon the preceding

table, Table 2B, Section VIII.

Section V III

ECONOMIC

ACTIVITIES

W. Va. Univ.

Agr. Exp. Sta.

Bul. No. 464

Page 94

\begin{tabular}{|c|c|c|c|c|c|c|c|}
\hline COUNTY & 1940 & 1950 & 1955 & 1957 & 1958 & 1959 & 1960 \\
\hline Barbour & 72.9 & 100.0 & 103.5 & 115.2 & 110.3 & 119.9 & $12 \% .0$ \\
\hline Berkeley & 65.7 & 100.0 & 115.9 & 119.9 & 121.0 & 122.4 & 128.8 \\
\hline Boone & 62.1 & 100.0 & 107.8 & 775.9 & 97,6 & 110.8 & 115.6 \\
\hline Braxton & $64 . ?$ & 100.0 & 123,7 & 150.4 & $1 / 5.5$ & 136.0 & 126.4 \\
\hline Brooke & 69.5 & 100.0 & 122.2 & 119.9 & 113.6 & 130.4 & 136.1 \\
\hline Cabell & 64.0 & 100.0 & 107.8 & 120.7 & 114.8 & 130.7 & 133.6 \\
\hline Calhoun & 94.4 & 100.0 & 109.2 & 133.2 & 131.2 & $11,3.7$ & 148.6 \\
\hline Clay & 70.2 & 100.0 & 88.4 & 93.7 & 84.4 & 102.9 & 102.6 \\
\hline Doddridge & 73.0 & 100.0 & 99.7 & 110.3 & 117.0 & 136.5 & 146.0 \\
\hline Fayette & 80.0 & 100.0 & 84.9 & 85.8 & 77.5 & 86.4 & 89.0 \\
\hline Gilmer & 75.9 & 10000 & 102.3 & 125.9 & 123.7 & 123.5 & 133.8 \\
\hline Grant & 42.4 & 100.0 & 104.8 & 119.9 & 117.2 & 115.2 & 119.1 \\
\hline Greenhrier & 57.4 & 100.0 & 107.6 & 121,1 & 113.6 & 114.0 & 114.9 \\
\hline Hampshire & 60.2 & 100.0 & 120.5 & 128.5 & 120.5 & 11.5 .6 & 150.6 \\
\hline Hancock & 72.8 & 100.0 & 115.4 & 130.5 & 123.8 & 147.2 & 153.8 \\
\hline Hardy & 48.6 & 100.0 & 132.9 & 147.5 & 138.4 & 156.8 & 165.3 \\
\hline Harrison & 62,6 & 100.0 & 25.3 & 106.7 & 101.1 & 101.6 & 104.8 \\
\hline Jackson & 56.9 & 100.0 & 119.6 & 190.0 & 176.1 & 166.4 & 174.4 \\
\hline Jefferson & 54.4 & 100.0 & 133.6 & 133.4 & 132.2 & 152.9 & 165.7 \\
\hline Kanawha & 66.0 & 100,0 & 113.6 & 127.3 & 121.5 & 128.5 & 132.8 \\
\hline Lewis & 71.0 & 100.0 & 97.6 & 101.8 & 102.0 & 121.7 & 127.3 \\
\hline Lincoln & 53.4 & 100.0 & 117.2 & 135.5 & 124.7 & 112.5 & 116.4 \\
\hline Logan & 67.7 & 100.0 & 82.2 & 97.4 & 81.6 & 86.0 & 84.8 \\
\hline McDowell & 99.9 & 100,0 & 97.5 & 99.4 & 82.7 & 81.2 & 79.0 \\
\hline Marion & 78.5 & 100.0 & 107.5 & 122.8 & 120.8 & 113.6 & 116.8 \\
\hline Marshall & 70.7 & 100.0 & 104.3 & 112.0 & 114.1 & 131.4 & 136.7 \\
\hline Masnn & 42.3 & 100.0 & 121.7 & 124.5 & 124.0 & 120.6 & 132.6 \\
\hline Mercer & 70.3 & 100.0 & 105.6 & 119.0 & 110.6 & 105.0 & 108.0 \\
\hline Mineral & 88.9 & 100.0 & 116.6 & 135.9 & 141.0 & 127.0 & 142.7 \\
\hline Mingo & 57.5 & 100.0 & 101.4 & 95.2 & 81.3 & 94.4 & 93.5 \\
\hline Monongalia & 68.1 & 100.0 & 101.8 & 111.9 & 103.3 & 101.2 & 102.9 \\
\hline Monroe & 57.5 & 100.0 & 109.1 & 127.2 & 129.5 & 106.9 & $11 / .2$ \\
\hline Morgan & 70.1 & 100.0 & 110.1 & 119.9 & 112.4 & 158.4 & 158.6 \\
\hline Nicholas & 38.3 & 200.0 & 117.8 & 137.2 & 118.3 & 128.5 & 135.4 \\
\hline Ohio & 81.7 & 100.0 & 116.3 & 124.0 & 117.0 & 114.6 & 123.4 \\
\hline Pendletoo & 73.4 & 100.0 & 131.6 & 125.4 & 127.8 & 139.0 & 138.2 \\
\hline Pleasants & 78.0 & 100.0 & 127.8 & 151.0 & 150.0 & 152.5 & 157.7 \\
\hline Pocahoatas & 81.5 & 100.0 & 123.3 & 149.1 & 127.7 & 120.8 & 124.9 \\
\hline Preston & 58.5 & 100.0 & 90.8 & 105.8 & 94.8 & 93.4 & 97.8 \\
\hline Putnam & 87.8 & 100.0 & 112.9 & 182.6 & 168.7 & 184.4 & 174.2 \\
\hline Raleigh & 86.8 & 100.0 & 90.6 & 112.3 & 101.6 & 101.5 & 104.1 \\
\hline Randolph & 75.1 & 100.0 & 105.8 & 119.9 & 117.7 & 116.7 & 123.5 \\
\hline Ritchie & 77.6 & 100.0 & 113.6 & 129.4 & 124.3 & 123.8 & 134.4 \\
\hline Roane & 30.2 & 100.0 & 106.2 & 117.6 & 116.8 & 122.1 & 131.0 \\
\hline Summers & 75.8 & 100.0 & 108.2 & 127.8 & 112.5 & 129.0 & 133.4 \\
\hline Taylor & 85.2 & 100.0 & 110.9 & 123.6 & 110.7 & 124.8 & 123.5 \\
\hline Tucker & 102.7 & 100.0 & 111.4 & 115.6 & 112.5 & 126.0 & 134.7 \\
\hline Tyler & 89.8 & 100.0 & 144.5 & 153.6 & 161.7 & 147.0 & 163.5 \\
\hline Upshar & 53.3 & 100.0 & 113.6 & 129.0 & 119.6 & 119.1 & 126.2 \\
\hline Wayne & 55.3 & 100.0 & 134.3 & 14.1 & 138.0 & 162.2 & 173.2 \\
\hline Webster & 63.7 & 100.0 & 97.6 & 113.4 & 102.2 & 102.6 & 101.7 \\
\hline Wetzel & 67.7 & 100.0 & 125.1 & 150.6 & 150.11 & 145.0 & 145.7 \\
\hline Wirt & 85.7 & 100.0 & 97.9 & 119.8 & 112.4 & 117.6 & 135.0 \\
\hline Wood & 67.4 & 100.0 & $109=0$ & 138,2 & 133.5 & $1 \longdiv { 8 . 8 }$ & 156.9 \\
\hline Wyomiog & 74.2 & $100, n$ & 130.2 & 163.2 & 137.1 & Jho.h & 148,2 \\
\hline TOTAL & 70.2 & 200.0 & 107.0 & 179.9 & 112.5 & 117.6 & 121.6 \\
\hline
\end{tabular}


Data presented in this and the following table, Table 3B, were derived from the Mineral Yearbook of 1941 and subsequent years. The Yearbood is a publication of the United States Department of Interior.

\begin{tabular}{|c|c|c|c|c|c|c|c|}
\hline COUNTY & 1940 & 1950 & 1955 & 1956 & 1957 & 1958 & 1959 \\
\hline Barbour & 1528 & 2147 & 1241 & 1365 & 1395 & 1165 & 1155 \\
\hline Berkeley & - & - & - & - & - & - & - \\
\hline Boone & 3566 & 5029 & 3057 & 3343 & 3188 & 2549 & 2283 \\
\hline Braxton & 27 & 119 & 82 & 92 & 148 & 145 & 168 \\
\hline Brooke & 1006 & 1213 & 576 & 552 & 475 & 517 & 247 \\
\hline Cabell & - & - & - & - & - & - & - \\
\hline Calhoun & - & $=$ & - & - & - & - & - \\
\hline Clay & 549 & 832 & 670 & 738 & $\star \star$ & 664 & $* *$ \\
\hline Doddridge & - & - & - & - & - & - & - \\
\hline Fayette & 12343 & 11397 & 5071 & 5255 & 4618 & 4237 & 3467 \\
\hline Gilmer & 33 & 141 & 58 & 55 & 118 & 178 & 187 \\
\hline Grant & 130 & 92 & 105 & 119 & 86 & 100 & 67 \\
\hline Greeahrier & 1880 & 2043 & 790 & 757 & 835 & 755 & 432 \\
\hline Hampshire & - & - & - & - & - & - & $\sim$ \\
\hline Hancock & 77 & 46 & 65 & 20 & 14 & - & - \\
\hline Hardy & - & - & - & - & - & - & - \\
\hline Harrison & 2594 & 5629 & 2494 & 3044 & 3218 & 2434 & 2231 \\
\hline Jackson & - & - & - & - & - & - & $=$ \\
\hline Jefferson & - & - & - & - & - & - & - \\
\hline Kanawha & 6798 & 7158 & 3741 & 4086 & 4138 & 3737 & 3630 \\
\hline Lewis & 14 & 122 & 194 & 201 & 227 & 162 & 157. \\
\hline Lincoln & $=$ & 73 & 3 & - & - & - & - \\
\hline Logan & 11445 & 14554 & 8663 & 9759 & 9840 & 7539 & 6859 \\
\hline McDowell & 20541 & 19209 & 9890 & 9911 & 9458 & 10103 & 7145 \\
\hline Marion & 5909 & 5279 & 3846 & 4006 & 4302 & 3836 & 3441 \\
\hline Marshall & 537 & 539 & 187 & 203 & $\star *$ & $\star \star *$ & $\star *$ \\
\hline Mason & 167 & 456 & 128 & 92 & 105 & 193 & 183 \\
\hline Mercer & 3808 & 2690 & 1101 & 1193 & 851 & 732 & 481 \\
\hline Mineral & 491 & 125 & 54 & 122 & $\hbar *$ & 85 & 89 \\
\hline Mingo & 3157 & 5202 & 3540 & 3423 & 3016 & 2204 & 2197 \\
\hline Monongalia & 4310 & 5998 & 2793 & 3141 & 3257 & 2458 & 2336 \\
\hline Monroe & - & - & - & - & - & - & - \\
\hline Morgan & - & - & - & - & - & - & - \\
\hline Nicholas & 177 & 3328 & 2750 & 3144 & 3332 & 3145 & 2804 \\
\hline Ohio & 1420 & 1206 & 413 & 401 & 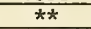 & $\star *$ & $\hbar \hbar$ \\
\hline Pendleton & - & - & - & - & - & - & - \\
\hline Pleasants & - & 28 & - & - & - & - & - \\
\hline Pocahoatas & - & 81 & $24 \overline{7}$ & 321 & 371 & 452 & 304 \\
\hline Preston & 1007 & 2834 & 1813 & 1833 & 1499 & 1171 & 1541 \\
\hline Putnam & 693 & 69 & 24 & 47 & 59 & 51 & 75 \\
\hline Raleigh & 13549 & 12052 & 5144 & 6269 & 6672 & 5585 & 4456 \\
\hline Randolph & 1289 & 1570 & 946 & 861 & 735 & 747 & 761 \\
\hline Ritchie & - & - & - & - & - & - & - \\
\hline Roane & - & - & - & - & - & - & - \\
\hline Summers & - & - & 6 & 10 & $=$ & 101 & - \\
\hline Taylor & 410 & 468 & 166 & 159 & 198 & 147 & 102 \\
\hline Tncker & 542 & 280 & 22 & 67 & 98 & 147 & 74 \\
\hline Tyler & - & - & - & - & - & - & - \\
\hline Upshur & 165 & 781 & 555 & 545 & 580 & 567 & 469 \\
\hline Wayoe & - & 486 & 109 & 95 & 132 & 38 & 106 \\
\hline Wehster & 1089 & 1589 & 556 & 649 & 647 & 546 & 457 \\
\hline Wetzel & - & - & - & - & - & - & - \\
\hline Wirt & - & - & - & - & - & - & - \\
\hline प9.2 * & 48 & - & - & - & 1609 & 916 & 1360 \\
\hline Wyoming & 3441 & 6027 & 5131 & 6118 & 5980 & 5031 & 4583 \\
\hline TOTAL & 104740 & 120892 & 66231 & 71996 & 71201 & 62437 & 53847 \\
\hline
\end{tabular}

Section V III ECONOMIC ACTIVITIES
W. Vo. Univ.

Agr. Exp. Sta. Bul. No. 464

Page 95

* Other counties. * Included in "other counties" to avoid disclosing individual operations. 
This index was prepared Irom data presented in the preceding

table, Table 3A, Section VIII.

Section V III

ECONOMIC

ACTIVITIES
W. Va. Univ. Agr. Exp. Sta. Bul. No. 464

Page 96

\begin{tabular}{|c|c|c|c|c|c|c|c|}
\hline COUNTY & 1940 & 1950 & 1955 & 1956 & 1957 & 1958 & 1959 \\
\hline Barbour & 71.2 & 100.0 & 57.8 & 63.6 & 65.0 & 54.3 & 53.8 \\
\hline Berkeley & - & - & - & - & - & - & - \\
\hline Boone & 70.9 & 100.0 & 60.8 & 66.5 & 63.4 & 50.7 & 45.4 \\
\hline Braxton & 22.7 & 100.0 & 68.9 & 77.3 & 124.4 & 121.8 & 141.2 \\
\hline Brooke & 82.9 & 100.0 & 47.5 & 45.5 & 39.2 & 42.6 & 20.4 \\
\hline Cabell & - & - & - & - & - & - & - \\
\hline Calhoun & - & - & - & - & - & - & - \\
\hline Clay & 66.0 & 100.0 & 80.5 & 88.7 & $* *$ & 79.8 & $* *$ \\
\hline Doddridge & - & - & - & - & - & - & - \\
\hline Fayette & 108.3 & 100.0 & 44.5 & 46.1 & 40.5 & 37.2 & 30.4 \\
\hline Gilmer & 23.4 & 100.0 & 41,1 & 39.0 & 83.7 & 126.2 & 132.6 \\
\hline Grant & 141.3 & 100.0 & 114.1 & 129.3 & 93.5 & 108.7 & 72.8 \\
\hline Greenbrier & 92.0 & 100.0 & 38.7 & 37.1 & 40.9 & 37.0 & 21.1 \\
\hline Hampshire & - & - & - & - & - & - & $=$ \\
\hline Hancock & 167.4 & 100.0 & 141.3 & 43.5 & 30.4 & - & - \\
\hline Hardy & - & $=$ & - & - & - & $=$ & $=$ \\
\hline Harrisoa & 46.1 & 100.0 & 44.3 & 54,1 & 57.2 & 43.2 & 39.6 \\
\hline Jackson & - & - & - & - & - & - & - \\
\hline Jeffersoo & - & - & - & - & - & - & - \\
\hline Kanawha & 95.0 & 100.0 & $52 . \overline{3}$ & 57.1 & 57.8 & 52.2 & 50.7 \\
\hline Lewis & 11.5 & 100.0 & 159.0 & 164.8 & 186.1 & 132.8 & 128.7 \\
\hline Lincoln & - & 100,0 & 4,1 & - & - & - & - \\
\hline Logan & 78.6 & 100.0 & 59.5 & 67.1 & 67.6 & 51.8 & 47.1 \\
\hline McDawell & 106.9 & 100.0 & 51.5 & 51.6 & 49.2 & 52.6 & 37.2 \\
\hline Marion & 111.9 & 100.0 & 72.9 & 75.9 & 81.5 & 72.7 & 65.2 \\
\hline Marsball & 99.6 & 100.0 & 34.7 & 37.7 & $\hbar *$ & ** & $* *$ \\
\hline Mason & 36.6 & 100.0 & 28.1 & 20.2 & 23.0 & 42.3 & 40.1 \\
\hline Mexcex & 141.6 & 100.0 & 40.9 & 44.3 & 31.6 & 27.2 & 17.9 \\
\hline Mineral & 392.8 & 100.0 & 43.2 & 97.6 & $k \hbar$ & 68.0 & 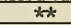 \\
\hline Mingo & 60.7 & 100.0 & 68.0 & 65.8 & 58.0 & 42.4 & 42.2 \\
\hline Monoogalia & 71.9 & 100.0 & 46.6 & 52.4 & 54,3 & 41.0 & 38.9 \\
\hline Monroe & - & - & - & - & - & - & - \\
\hline Margan & - & - & - & - & - & - &  \\
\hline Nicholas & 5.3 & 100.0 & 82.6 & 94.5 & 100.1 & 94.5 & 84.3 \\
\hline Ohio & 117.7 & 100.0 & 34.2 & 33.2 & $\star \star$ & $\star \star$ & $* \star$ \\
\hline Pendleton & - & - & - & - & - & - & - \\
\hline Pleasants & - & 100.0 & - & - & - & - & - \\
\hline Pocabootas & - & 100.0 & 304.9 & 396.3 & 458.0 & 558.0 & 375.3 \\
\hline Prestoa & 35.5 & 100.0 & 64.0 & 64.7 & 52.9 & 41.3 & 54.4 \\
\hline Putoam & 1004.3 & 100.0 & 34.8 & 68.1 & 85.5 & 73.9 & 108.7 \\
\hline Raleigh & 112.4 & 100.0 & 42.7 & 52.0 & 55.4 & 46.3 & 37.0 \\
\hline Randolph & 82.1 & 100.0 & 60.3 & 54.8 & 46.8 & 47.6 & 48.5 \\
\hline Ritchie & - & - & - & - & - & - & - \\
\hline Roane & - & - & - & - & - & - & - \\
\hline Summers & - & - & 100.0 & 166.7 & - & 1683,3 & - \\
\hline Taylas & 87.6 & 100.0 & 35.5 & 34.0 & 42.3 & 31.4 & 21.8 \\
\hline Tucker & 193.6 & 100.0 & 7.9 & 23.9 & 35.0 & 52.5 & 26.4 \\
\hline Tyler & - & - & - & - & - & $=$ & - \\
\hline Upsbur & 21.1 & 100,0 & 71.1 & 69.8 & 74.3 & 72.6 & 60.1 \\
\hline Wayae & - & 100.0 & 22.4 & 19.5 & 27.2 & 7.8 & 21.8 \\
\hline Webster & 68.5 & 100.0 & 35.0 & 40.8 & 40.7 & 34,4 & 28.8 \\
\hline Wetzel & - & - & - & - & - & - & - \\
\hline Wirt & - & - & - & - & - & - & - \\
\hline I606 * & - & - & - & - & - & - & $=$ \\
\hline Wyoming & 57.1 & 100.0 & 85.1 & 101.5 & 99.2 & 83.5 & 76.0 \\
\hline TOTAL & 86.6 & 100.0 & 54.8 & 59.6 & 58.9 & 51.6 & 44.5 \\
\hline
\end{tabular}

* Other counties. ** Included in "other counties" to avold disclosing Individual operations. 



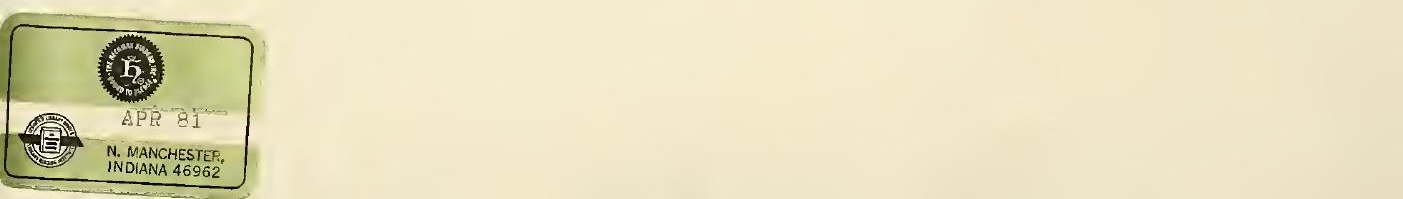


